VILNIAUS GEDIMINO TECHNIKOS UNIVERSITETAS

Matas BULEVIČIUS

\title{
KELIŲ TAMPRIOSIOS DANGOS KONSTRUKCIJŲ SAVYBIŲ ITAKA JŲ VIRŠUTINIO SLUOKSNIO EKSPLOATACINIAMS RODIKLIAMS
}

DAKTARO DISERTACIJA

TECHNOLOGIJOS MOKSLAI, STATYBOS INŽINERIJA (02T)

Vilnius $\frac{\square}{\substack{\text { VGTU } \\ \text { TEIDYKLA }}} 2013$ 
Disertacija rengta 2008-2013 metais Vilniaus Gedimino technikos universitete.

\section{Mokslinis vadovas}

prof. dr. Kazys PETKEVIČIUS (Vilniaus Gedimino technikos universitetas, technologijos mokslai, statybos inžinerija - 02T).

VGTU leidyklos TECHNIKA 2189-M mokslo literatūros knyga

ISBN 978-609-457-582-2

(C) VGTU leidykla TECHNIKA, 2013

(C) Matas Bulevičius, 2013

matas.bulevicius@vgtu.lt 
VILNIUS GEDIMINAS TECHNICAL UNIVERSITY

Matas BULEVIČIUS

\section{INFLUENCE OF THE PROPERTIES OF FLEXIBLE ROAD PAVEMENT STRUCTURE ON THE SERVICE INDICES OF WEARING COURSES}

DOCTORAL DISSERTATION

TECHNOLOGICAL SCIENCES,

CIVIL ENGINEERING (02T)

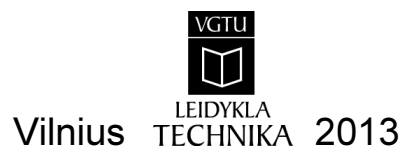


Doctoral dissertation was prepared at Vilnius Gediminas Technical University in 2008-2013.

\section{Scientific Supervisor}

Prof Dr Kazys PETKEVIČIUS (Vilnius Gediminas Technical University, Technological Sciences, Civil Engineering - 02T). 


\section{Reziumè}

Disertacijos tikslas - parengti magistralinių automobilių kelių asfaltbetoninès dangos eksploatacinių rodiklių prognozès matematinius modelius, atsižvelgiant i tampriosios dangos konstrukcijos savybes ir transporto priemonių (TP) eismo intensyvumą (EI). Darbe iškelti šie svarbiausieji uždaviniai: išanalizuoti automobilių kelių asfaltbetoninès (AB) dangos eksploatacinius rodiklius lemiančius svarbiausius veiksnius ir atskleisti šių rodiklių blogejjimo priežastis; atlikti magistralinių kelių dangos konstrukcijų (KDK) sluoksniams naudojamų medžiagų kokybès rodiklių tyrimus; nustatyti $\mathrm{AB}$ dangos komponentinès sudèties, fizinių bei mechaniniu rodikliu ir $\mathrm{AB}$ mišiniams naudojamu medžiagu kokybès rodiklių sietį; ištirti $A B$ dangos lygumo ir provėžų gylio kitejjimo dèsningumus; nustatyti $\mathrm{AB}$ dangos, kitų (KDK) sluoksnių medžiagu kokybès rodiklių sietị; parinkti dvi racionalias magistralinių kelių tampriosios dangos konstrukcijas (skirtingam TP eismui).

Disertaciją sudaro įvadas, keturi skyriai, rezultatų apibendrinimas, naudotos literatūros ir autoriaus publikacijų disertacijos tema sąrašai ir priedai.

Ivade aptarta tiriamoji problema, darbo aktualumas, tyrimų objektas, darbo tikslas ir uždaviniai, tyrimų metodika, darbo mokslinis naujumas, darbo rezultatų praktinè vertè ir ginamieji teiginiai.

Pirmajame skyriuje išnagrinèti ịvairių šalių mokslininkų atlikti automobilių kelių asfaltinès dangos bei jos konstrukcijos eksploatacinių rodiklių ir jų funkcionavimo trukmès tyrimai.

Antrajame skyriuje pateikti teoriniai tyrimai $\mathrm{AB}$ dangos ir jos konstrukcijos funkcionavimo sąlygoms, eksploataciniams rodikliams ir KDK sluoksnių medžiagų savybėms nustatyti.

Trečiajame skyriuje pateikta atliktų tyrimų metodika, AB dangos eksploatacinių rodiklių ir KDK sluoksnių medžiagu savybių bei jų sieties tyrimai. Taip pat pateikti KDK sluoksniams naudojamų medžiagu fizinių bei mechaninių ir geometrinių rodiklių tyrimai.

Ketvirtajame skyriuje pasiūlyti magistralinių automobilių keliu asfaltbetoninès dangos eksploatacinių rodiklių prognozès (penkerių metų) laikotarpiui matematiniai modeliai. Parinktos dvi racionalios magistralinių kelių tampriosios dangos konstrukcijos TP eismo intensyvumui iki 10000 aut./parą ir TP eismo intensyvumui iki 30000 aut./parą.

Disertacijos tema paskelbti šeši moksliniai straipsniai: du - mokslo žurnaluose, itrauktuose ị Thomson Reuters Web of Knowledge duomenų bazę, trys - recenzuojamuose tarptautinių konferencijų leidiniuose, itrauktuose i Thomson ISI Proceeding duomenų bazę, vienas - tarptautinių konferencijų straipsniu rinkiniuose. 


\section{Abstract}

The aim of the dissertation is based on the properties of flexible road pavement structures to develop a mathematical models for predicting the performance of wearing courses used in the pavements of the main roads. The main tasks of the dissertation are as follows: to analyze the main factors influencing the service indices of asphalt concrete pavements and to determine their reasons; to investigate the quality of materials and mixtures used in pavement structural layers of the main roads; to determine the interaction between asphalt concrete pavement composition and the quality indices of mixture materials; to study regularities of the change in pavement roughness and rut depth; to determine the interaction between the quality indices of materials used in pavement structural layers; to select two rational flexible pavement structures for the main roads (for the different traffic volume).

The dissertation consists of introduction, four chapters, general conclusions, the list of references and the list of author's publications on the topic of the dissertation, addenda.

Introduction describes the studied problem, topicality of the problem, the object of research, also the aim and tasks, research methodology, scientific novelty, practical value of the results and the defended propositions.

Chapter 1 gives the analysis of scientific researches made by different countries in the field of the performance of asphalt concrete pavements and their structures, duration of their service life.

Chapter 2 describes theoretical investigations to determine the service indices of asphalt concrete pavements and their structures, material properties of pavement structural layers, and time intervals between pavement repairs.

Chapter 3 gives the research methodology, presents investigations in the service indices of asphalt concrete pavements and material properties of structural pavement layers, as well as their interaction. Also, studies the physical, mechanical and geometrical indices of materials used in pavement structural layers.

Chapter 4 suggests mathematical models for predicting asphalt concrete pavement service indices in a period of 5 years. Two rational flexible pavement structures have been selected for the main roads: for the traffic volume of 10000 veh./day and up to $30000 \mathrm{veh} . /$ day.

On the topic of the dissertation 6 scientific articles have been published: two - in scientific journals included into the list of Thomson Reuters Web of Knowledge, three - in the reviewed international conference proceedings included into the Thomson ISI Proceedings, one - in the proceedings of international conferences. 


\section{Sąvokos}

Kelias - eismui skirta (ir naudojama) žemės arba kelių statinio paviršiaus juosta, iskaitant važiuojamają dali, kelkraščius, sankryžas, pėsčiujjų ir dviračių takus, transporto priemonių (TP) srautų atskyrimo juostas.

Kelio (kelių) tamprioji danga - eismui skirtos važiuojamosios dalies viršutinè dalis (viršutinis ir apatinis sluoksniai), tiesiogiai priimanti transporto priemonių apkrovas ir jas paskirstanti žemiau esantiems kelių dangos konstrukcijos sluoksniams, taip pat tiesiogiai veikiama (viršutinis sluoksnis) oro temperatūros, saulès spinduliuotès, oro deguonies, kritulių, vèjo ir kitų veiksnių. Ji būna asfaltbetoninè ar kita asfaltinè.

Kelio (kelių) dangos būtinasis remontas - neišvengiamas kelių dangos (KD) remontas, kuri būtina kuo skubiau atlikti, kai KD lygumas ir/ar jos suirties mastas viršija savo leidžiamają (ribinę) vertę.

Kelio (kelių) dangos funkcionavimo trukmè - kelių dangos (KD) funkcionavimo nuo įrengimo iki jos būtinojo remonto arba jos funkcionavimo tarp būtinujų remontų laikotarpis (tarpremontinis laikotarpis).

Kelio (kelių) tampriosios dangos konstrukcija - eismui skirtos važiuojamosios dalies konstrukcija, sudaryta iš asfaltbetoninès $(A B)$ dangos ir žemiau esančiu pagrindo sluoksnių (asfaltbetonio ar kito asfalto, skaldos, žvyro ar smèlio ir žvyro mišinio arba kitos medžiagos - kapiliarus nutraukiančios ir/ar šilumą izoliuojančios). Jos paskirtis - priimti TP apkrovas ir jas tolygiai 
paskirstyti žemès sankasos grunte, taip pat apsaugoti kelio (kelių) dangą nuo kapiliarinio vandens šaltuoju metų laikotarpiu ir nuo perteklinès drègmès pavasario polaidžio ir rudens liūčių metu.

Kelio (kelių) dangos konstrukcijos funkcionavimo trukmè - kelių dangos konstrukcijos (KDK) funkcionavimo nuo įrengimo iki jos būtinojo remonto arba jos funkcionavimo tarp būtinụjų remontų laikotarpis (tarpremontinis laikotarpis). Kelio (keliụ) dangos lygumas - kelių dangos eksploatacinis (būklès) rodiklis, rodantis, kiek dangos paviršius (važiavimo kryptimi) yra nukrypęs nuo tam tikros idealios linijos, rodančios visišką (idealų) dangos lygumą. Dangos lygumas Lietuvoje nustatomas greitaeigèmis, keliu $80 \mathrm{~km} / \mathrm{h}$ greičiu važiuojančiomis mobiliosiomis laboratorijomis DYNATEST 5051 RSP ar RST28, vertinamas tarptautinio lygumo rodiklio IRI (International Rougnhness Index) vienetais, išreikštais $\mathrm{m} / \mathrm{km}$. Rodiklis $I R I$ - tai suma automobilio vibracijų, kurias sukelia kelio išilginio profilio nelygumai věžèse - standartinio automobilio, važiuojančio $80 \mathrm{~km} / \mathrm{h}$ greičiu, pakabos vertikaliųjų poslinkių sumos ir nuvažiuoto kelio santykis.

Kelio (kelių) dangos provèža - keliụ dangos eksploatacinis (būklès) rodiklis, rodantis kiek transporto priemonių (TP) judejjimo kryptimi susidariusi ištisinè iduba yra nukrypusi nuo tam tikros, statmenos važiavimo krypčiai linijos, rodančios visišką (idealų) dangos lygumą; KD provèža taip pat charakterizuojama pagal jos ploti.

Kelio (kelių) tampriosios dangos racionali konstrukcija - eismui skirtos važiuojamosios dalies konstrukcija, sudaryta iš dangos ir žemiau esančių pagrindo sluoksnių (asfaltbetonio ar kito asfalto, skaldos, žvyro ar smèlio ir žvyro mišinio arba kitos medžiagos - kapiliarus nutraukiančios ir/ar šilumą izoliuojančios), kurių savybès ir storiai atitinka dangos funkcionavimo sąlygas, esant mažiausiai įrengimo kainai.

Kelio (kelių) dangos suirties mastas - kelių dangos eksploatacinis (būklès) rodiklis, rodantis, kiek (kuria dalimi, \%) danga suirusi (pažeista defektų). Dangos suirties mastas nustatomas atliekant matavimus mobiliąa laboratorija RST-28.

Kelio (kelių) dangos defektai - KD liekamosios deformacijos: skersiniai, išilginiai ir įstrižieji plyšiai, briaunų, sandūrų ir nuovargio plyšiai, plyšių tinklas, išaižos, ištrupos, briaunų (kraštų) ištrupos, išdaužos, igriuvos (ilūžiai), iškylos prie plyšių, kelkraščiu nuosèdžiai, vèžès, bangos, slinktys, plyšiai (dèl slinkčių), įdubos, bitumo dèmès ir kt. Pagal KD defektų pobūdi galima nustatyti KD suirties priežastis.

Sunkioji transporto priemonè - krovininis, didesnis kaip 3,5 tonos masès, automobilis, su priekaba ar puspriekabe, ir daugiau kaip 9 sédimų vietų, įskaičiuojant vairuotojo vietą, autobusas. 
Tyrimų ruožai: pirmasis (1-asis) ir antrasis (2-asis) - tai kelio KaunasMarijampolè-Suvalkai A5, kairèje pusèje esantys KDK ruožai, įrengti 2005 m; pirmojo kelio ruožo ilgis $6,3 \mathrm{~km}$ (nuo $0,0 \mathrm{~km}$ iki $6,3 \mathrm{~km}$ ), o antrojo ilgis $4,5 \mathrm{~km}$ (nuo $25,8 \mathrm{~km}$ iki $30,3 \mathrm{~km}$ ).

Transporto priemonè - motorine ar biologine trauka (žmonių, taip pat arklių ir kitų nešulius ar vežimus traukiančių gyvulių raumenų jèga) aprūpinta priemonè žmonèms (keleiviams) ir/ar kroviniams, taip pat ant jos sumontuotai stacionariai įrangai vežti. Ši sąvoka taip pat apima traktorius, savaeiges mašinas ir eismui ne keliais (dviračių takais ir kt.) skirtas transporto priemones. 



\section{Žymèjimai}

\section{Simboliai}

$T$ - funkcionavimo trukmè, metais.

$L \quad$ - kelių dangos (KD) bandymų ruožo ilgis, $\mathrm{km}$.

$Y_{I R I}-\mathrm{KD}$ lygumo rodiklio pagal tarptautinį indeksą $I R I$ verte, $\mathrm{m} / \mathrm{km}$.

$H_{\mathrm{V}}-\mathrm{KD}$ vèžès gylis, $\mathrm{mm}$.

$D_{\mathrm{D}}-\mathrm{KD}$ suirties mastas, $\%$.

$N$ - transporto priemonių (TP) eismo intensyvumas, aut./parą.

$\sigma \quad$ - tempimo itempiai, MPa.

E - tampros modulis, MPa.

$h-$ KDK sluoksnių storis, $\mathrm{mm}$.

SI - formos rodiklis, \%.

FI - plokštumo rodiklis, \%.

$\rho \quad-$ sausasis tankis, $\mathrm{Mg} / \mathrm{m}^{3}$.

$F \quad$ - atsparumas šaldymui-atšildymui, $\%$.

$L A$ - atsparumas trupinimui.

$S Z$ - atsparumas smūgiams, \%.

$V \quad$ - asfaltbetonio tuštymètumo rodiklis, $\%$.

$B$ - bituminio rišiklio kiekis (100 \% asfaltinio mišinio mineralinės dalies), masè $\%$.

$B / M M$ - bituminio rišiklio ir mineralinių miltelių santykis, vieneto dalimis.

$k \quad-$ KD sluoksnio sutankinimo laipsnis, $\%$. 
$M M$ - mineralinių miltelių (išbirų pro 0,09 mm skersmens akelių sietą) kiekis, masės \%. SK - skaldos (liekanos ant $2 \mathrm{~mm}$ skersmens akelių sieto) kiekis, masès \%.

\section{Santrumpos}

AASHTO - Amerikos (JAV) keliụ ir transporto pareigūnų asociacija

(angl. American Association of State Highway and Transportation Officials).

$\mathrm{AB}-$ asfaltbetonis.

AM - asfaltinis mišinys.

AŠAS - apsauginis šalčiui atsparus sluoksnis.

DAVASEMA - dangų (būklès) valdymo sistema, sukurta Lietuvoje.

DVS - dangų (būklès) valdymo sistema.

EI - eismo intensyvumas.

$E S A_{100}$ - vidutinis metinis paros standartinių ašių ekvivalentas, kai $100 \mathrm{kN}$ laikoma standartine apkrova.

ES - Europos Sajunga.

GVL - gruntinio vandens lygis.

HDM - keliu plètros ir valdymo modelis (angl. Highway Development and Management Tool).

IRI - kelių dangos lygumo tarptautinis rodiklis (angl. International Ratio Index).

KD - kelių danga.

KDK - kelių dangos konstrukcija.

KK - kelio konstrukcija.

KR - kokybès rodiklis.

KTTI - Všt̨ Kelių ir transporto tyrimo institutas

KVK - konvekcija (šilumos mainai).

STP - sunkioji transporto priemonè.

TKTI - Vİ Transporto ir kelių tyrimo institutas.

TP - transporto priemone.

VMPEI - vidutinis metinis paros transporto priemonių eismo intensyvumas.

ŠNS - šalčiui nejautrus sluoksnis.

ŽS - žemès sankasa. 


\section{Turinys}

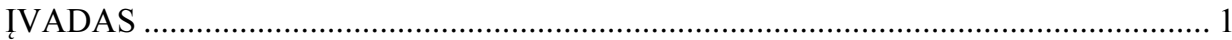

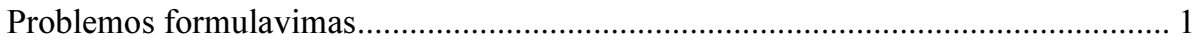

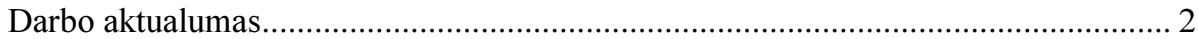

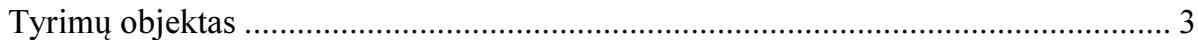

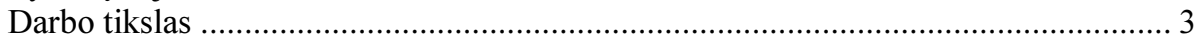

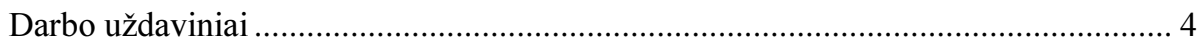

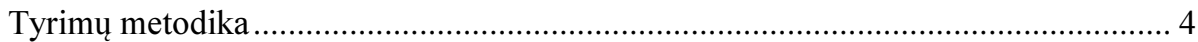

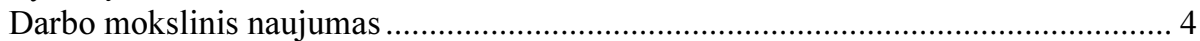

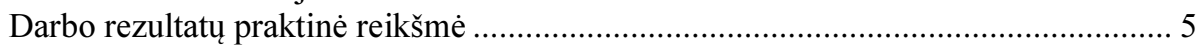

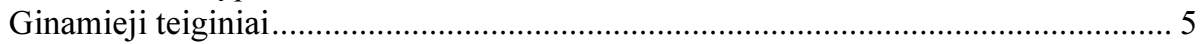

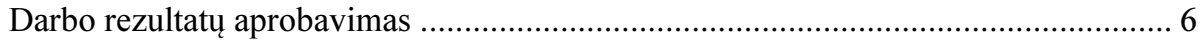

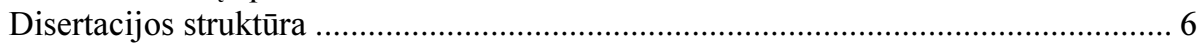

1. AUTOMOBILIŲ KELIŲ TAMPRIOSIOS DANGOS KONSTRUKCIJŲ SU ASFALTBETONINE DANGA ATLIKTU TYRIMU巳 ANALIZĖ............................. 7

1.1. Lietuvos automobilių keliai ir jų įvertinimas .................................................... 7

1.2. Automobilių kelių tampriosios dangos konstrukcijų ir asfaltbetoninès dangos

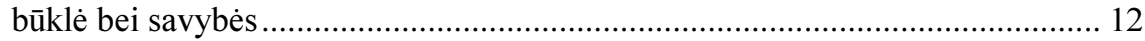

1.3. Kelių tampriosios dangos konstrukcijų sluoksnių medžiagos ir jų savybès ....... 15

1.4. Transporto priemonių eismo ir klimato bei vietos sąlygu itaka kelių tampriosios dangos konstrukcijoms .............................................................. 20

1.5. Kelių tampriosios dangos konstrukcijų defektai ir jų susidarymo priežastys..... 27

1.6. Pirmojo skyriaus išvados ir darbo uždavinių formulavimas............................... 32 


\section{AUTOMOBILIU KELIU TAMPRIOSIOS DANGOS KONSTRUKCIJU}

PROJEKTAVIMO SVARBIAUSIEJI PRINCIPAI................................................ 35

2.1. Asfaltbetoninės dangos ir kitų konstrukcinių sluoksnių funkcionavimo

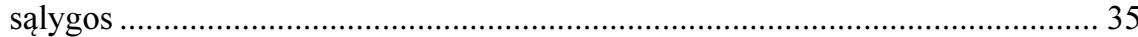

2.2. Kelių tampriosios dangos konstrukcijų funkcionavimo trukmè......................... 41

2.3. Kelių tampriosios dangos konstrukcinių sluoksnių projektavimo pagrindimas . 45

2.4. Kelių tampriosios dangos racionalių konstrukcijų parinkimas............................ 48

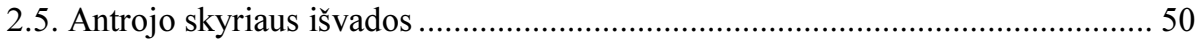

3. KONSTRUKCINIŲ SLUOKSNIŲ IR JŲ MEDŽIAGŲ SAVYBIŲ TYRIMAI .......51

3.1. Tyrimų atlikimo ir duomenų apdorojimo metodika .......................................... 51

3.1.1. Laboratorinių tyrimų metodai.................................................................. 55



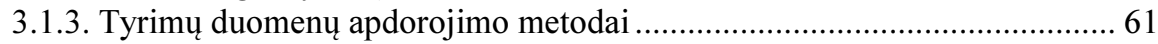

3.2. Kelių dangos konstrukcijų medžiagų savybių rodiklių tyrimai ........................... 65

3.3. Konstrukcinių sluoksnių medžiagų savybių analizè.......................................... 72

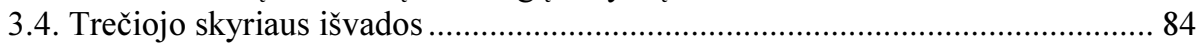

4. KONSTRUKCINIŲ SLUOKSNIŲ, JŲ MEDŽIAGŲ SAVYBIỤ ANALIZĖ, VERTINIMAS IR RACIONALIŲ KONSTRUKCIJŲ PARINKIMAS .................... 87

4.1. Konstrukcinių sluoksnių ir jų medžiagų savybiụ įtakos kelių tampriosios dangos viršutinio sluoksnio eksploataciniams rodikliams tyrimai bei analizè.... 87

4.2. Konstrukcinių sluoksnių ir jų medžiagų savybių vertinimas............................. 91

4.2.1. Pirmojo tyrimų ruožo rodiklių jautrumo analizè ........................................ 93

4.2.2. Antrojo tyrimų ruožo rodiklių jautrumo analizè......................................... 95

4.3. Magistralinių kelių tampriosios dangos racionalių konstrukcijų modeliavimas

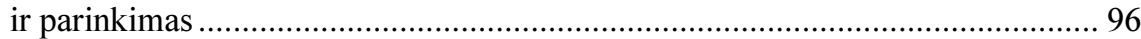

4.3.1. Pirmojo tyrimų ruožo modeliavimo rezultatų neapibrěžties analizè........... 97

4.3.2. Antrojo tyrimų ruožo modeliavimo rezultatų neapibrěžties analizè.......... 100

4.3.3.Magistralinių keliụ tampriosios dangos racionalių konstrukcijų

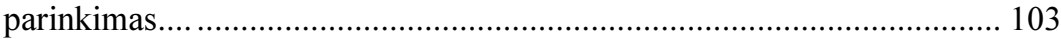

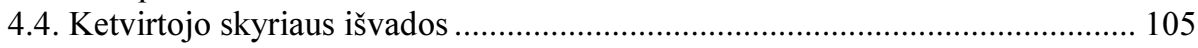

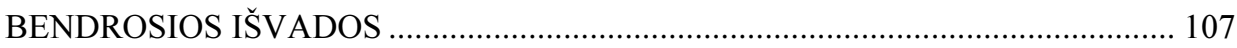

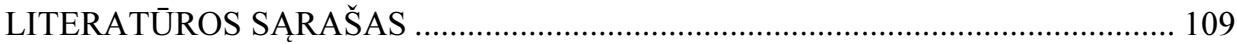

AUTORIAUS MOKSLINIŲ PUBLIKACIJŲ DISERTACIJOS TEMA SĄRAŠAS . 123

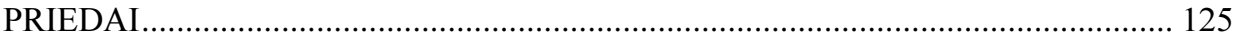

A priedas. Kelio dangos konstrukcinių sluoksnių savybių sieties analizè................ 126

B priedas. Kelio dangos konstrukcinių sluoksnių rodiklių skirstiniai ...................... 134

C priedas. Sugeneruoti kelio dangos konstrukcinių sluoksnių rodikliai................... 184

D priedas. Sugeneruotos kelio dangos konstrukcijos ............................................ 382 


\section{Contents}

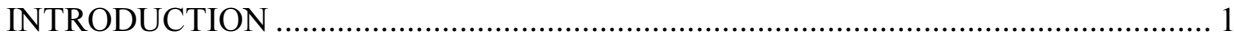

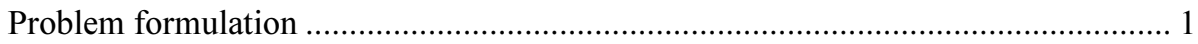

Topicality of the problem.............................................................................. 2

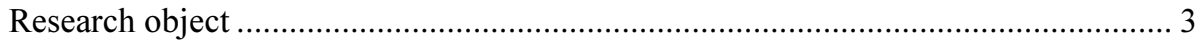

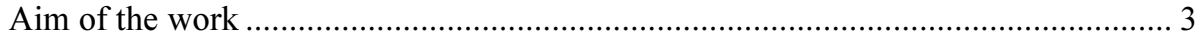



Methodology of research....................................................................................... 4

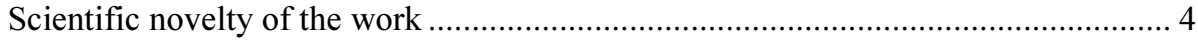

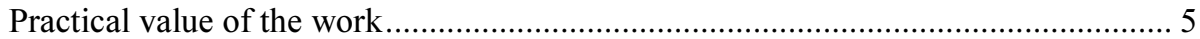

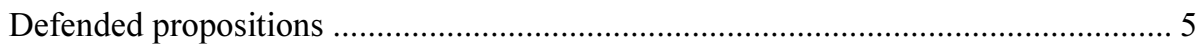

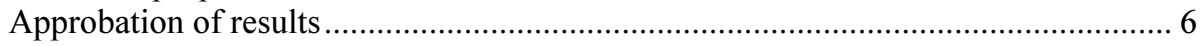

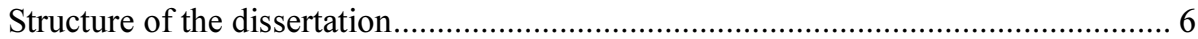

1. ANALYSIS OF RESEARCH IN THE FIELD OF FLEXIBLE PAVEMENT STRUCTURES WITH ASPHALT CONCRETE PAVEMENT ............................... 7

1.1. The motor roads of Lithuania and their evaluation ............................................ 7

1.2. Condition and properties of flexible road pavement structures and asphalt

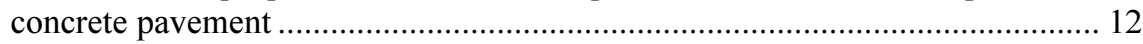

1.3. Materials and their properties of flexible road pavement structures .................. 15

1.4. Influence of vehicle traffic, climate and local conditions on flexible road

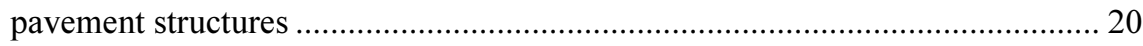

1.5. Defects and their causes in flexible road pavement structures .......................... 27

1.6. Conclusions of chapter 1 and formulation of the tasks of work ......................... 32

2. MAIN PRINCIPLES IN THE DESIGN OF FLEXIBLE ROAD PAVEMENT

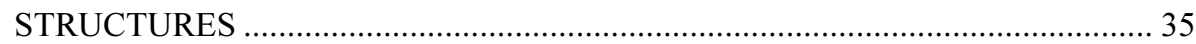

2.1. Service conditions of asphalt concrete pavement and other structural layers .... 35

2.2. Duration of the service life of asphalt concrete pavement structure................... 41

2.3. Design substantiation of the structural layers of flexible road pavement........... 45 
2.4 Selection of rational flexible pavement structures

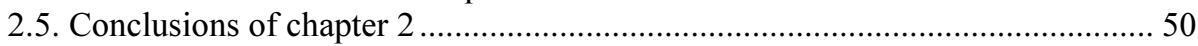

3. RESEARCH IN THE STRUCTURAL LAYERS AND THEIR MATERIAL

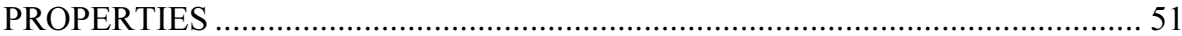

3.1. Methodology for the research implementation and data processing ................. 51

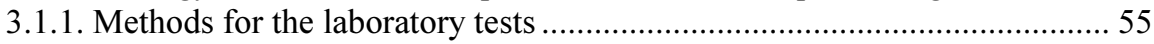

3.1.2. Methods of the road pavement research ...................................................... 59

3.1.3. Methods for the processing of research results............................................. 61

3.2. Research of the indices of material properties of road pavement structure........ 65

3.3. Research of the material properties of structural layers …………………......... 72

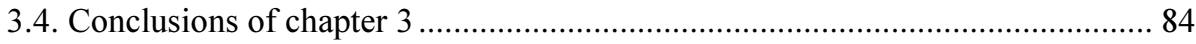

4. ANALYSIS AND EVALUATION OF THE PROPERTIES OF STRUCTURAL LAYERS, THEIR MATERIALS, AND SELECTION OF RATIONAL

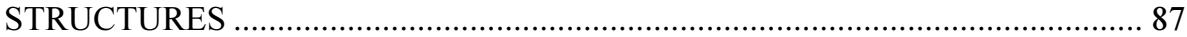

4.1. Research and analysis on the influence of properties of structural layers and their materials on asphalt concrete road pavement ……….................................. 87

4.2. Evaluation of the properties of structural layers and their materials .................. 91

4.2.1. Sensitivity analysis of the indices of the first experimental road section ... 93

4.2.2. Sensitivity analysis of the indices of the second experimental road

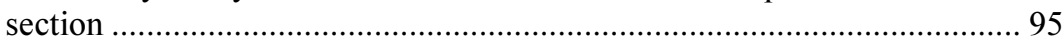

4.3. Modelling and selection of rational road pavement structure for the main

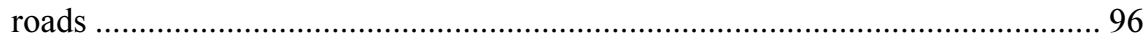

4.3.1. Uncertainty analysis of the modelling results of the first experimental

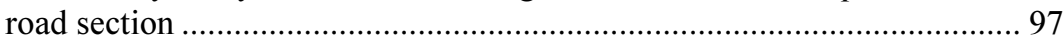

4.3.2.Uncertainty analysis of the modelling results of the second experimental road section..................................................................... 100

4.3.3. Selection of a rational road pavement structure for the main roads.......... 103

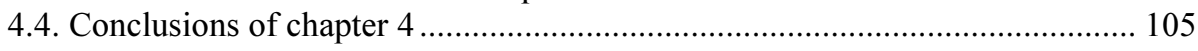

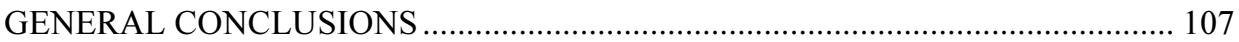

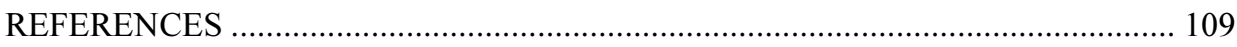

LIST OF PUBLISHED WORKS BY THE AUTHOR ON THE TOPIC OF THE

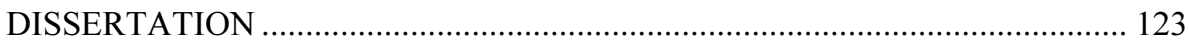



Addenda A. Evaluation of the correlation of the indices of material of road

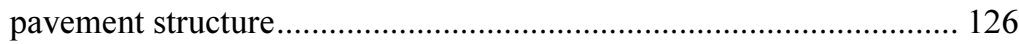

Addenda B. Distribution analysis of material of road pavement structure.............. 134

Addenda C. Generated indices of material of road pavement structure .................. 184

Addenda D. Generated road pavement structure ................................................... 382 


\section{Ivadas}

\section{Problemos formulavimas}

Lyginant su išsivysčiusiomis šalimis, Lietuvos automobilių kelių tinklas jau gana gerai išplètotas. Dabar svarbiausia ji tausoti, tinkamai prižiūrèti ir tobulinti taip, kad jis sklandžiai funkcionuotų Europos kelių tinkle. Dabartinès automobilių kelių plètros problemos dažniausiai susijusios su mažu kelių laidumu, kelių dangos stipriu ir ilgalaikiškumu.

Automobilių kelių asfaltbetoninès dangos eksploatavimo ir priežiūros patirtis rodo, kad ši danga dažniausiai funkcionuoja trumpiau nei galètų. Žiemą, rudeni ir pavasarị, esant nepalankiems orams, keliu asfaltbetoninejje dangoje atsiranda plyšių, išdaužų, ištrupų, išaižų ir kitų defektų, o vasarą esant aukštai temperatūrai, ikkaitus dangai - provėžų, bangų slinkčių ir kitų liekamujjų šlyties deformacijų. Laikui bègant šių defektų daugeja, jų įtaka intensyveja, o jais pažeistos dangos plotas didèja, todèl laikui bègant sumažèja keliu važiuojančių transporto priemonių (TP) srauto greitis ir eismo saugumas, o kelias tampa sunkiai pravažiuojamas. Dažniausiai kelių dangos priežiūros ir taisymo problemos būna susijusios su daugiaašių sunkiụu automobilių skaičiaus didejimu. Lietuvos keliai pagal dangos lygumą, dangos konstrukcijos stipri ir kitus rodiklius dažnai nèra pritaikyti didelių gabaritų sunkiesiems automobiliams. 
Kelių dangos irtị spartina šie veiksniai:

- stipriai padidèjęs krovininių TP eismo intensyvumas;

- padidejusios TP ašiu apkrovos, kurios neretai gerokai viršija normines apkrovas, taikytas anksčiau projektuojant kelių dangą;

- transporto priemonès, kurių masè TP sraute viršija leistinają leidžiamąją masę.

Kelių danga - vienas svarbiausių kelio elementų, kuriame dinaminių ir statinių apkrovų bei aplinkos poveikis sukelia žemès sankasos gruntų bei kelių dangos konstrukcijos (KDK) sluoksnių stiprio pokyčius. Kelių dangos lygumas $I R I$, provèžų gylis ir dangos suirties mastas - tai vieni svarbiausių dangos eksploatacinių rodiklių, rodančių kelių dangos konstrukcijų gebẻjimą atlaikyti transporto priemonių apkrovas. Esamų dangos konstrukcijų laikomoji geba ir jų stiprinimo poreikis dažniausiai nustatomi vadovaujantis dangos būklès ir jos konstrukcijos stiprio tyrimais, tačiau Lietuvoje nèra eksperimentiniais tyrimais pagrịstos ir aprobuotos metodikos, kuria vadovaujantis būtu galima nustatyti esamų kelių dangos konstrukcijų laikomają gebą, todèl, tiesiant kelius, dažniausiai parenkamos tipinès kelių dangos konstrukcijos, neskaičiuojant jų stiprio. Siekiant optimaliai panaudoti turimas Lietuvos valstybès biudžeto lèšas, tikslinga parinkti racionalias, vietos TP eismo ir kitas sąlygas geriausiai atitinkančias, kelių dangos konstrukcijas, naudojant tinkamas konstrukcines medžiagas, kurios užtikrintų kuo geresnes KD eksploatacines savybes visu jos funkcionavimo laikotarpiu.

\section{Darbo aktualumas}

Šiuolaikiniai kelių dangos konstrukcijų tyrimo metodai ir taikomos kompiuterinès programos pagristos tamprumo teorija. Ši teorija plačiausiai taikoma kelių dangos konstrukcijos modelyje, kai nuo automobilio rato perduodama apkrova keliu dangai, dangos konstrukcijoje sukelia itempius ir deformacijas. Lietuvoje kelių dangos konstrukcijų sluoksniai parenkami laikantis šalyje naudojamų norminių dokumentu reikalavimų ir naudojantis KDK sluoksnių medžiagų tyrimų rezultatais bei sukaupta inžinerine patirtimi.

Stiprinant kelių dangą, dažnai tenka įvertinti jos likutinị stiprị ir nustatyti atskiru jos sluoksnių bei grunto stiprio rodiklius. Šie uždaviniai tampa vis aktualesni tose šalyse, kuriose kelių tinklas jau yra suformuotas ir didžiausia darbų apimtis siejama su KDK racionalios būklès užtikrinimu, todèl atsiranda vis didesnis poreikis KDK sluoksnius parinkti taikant modernius KDK projektavimo metodus, atliekant reikiamus medžiagų tyrimus ir vertinant KDK 
sluoksnių medžiagu kokybès rodiklius, taip pat naudojant naujas medžiagų gamybos ir kelių tiesybos technologijas.

Riboto finansavimo sąlygomis prioritetiniais tampa kelių dangos ilgalaikiškumo rodikliai ir naudojamų medžiagų kaina, taip pat racionalus bei diferencijuotas požiūris ị kelių dangos stiprinimą, ịvertinant vietovès klimato bei hidrologines sąlygas, likutinį KDK sluoksnių stiprį ir automobilių ašių apkrovas.

Iki šiol dar nesukurta metodika, kurią taikant būtų galima gana tiksliai ịvertinti reikiamą KDK stiprị ir parinkti racionalius KDK sluoksnių storius, ivvertinus naudojamu jiems ịrengti medžiagu kokybès rodiklius. Lietuvoje pastaraisiais metais norminiu dokumentu „Automobiliu keliu standartizuotu dangų konstrukcijų projektavimo taisyklès KPT SDK 07“"iteisinta metodika tik KDK pagal projektinę apkrovą A parinkti, o reikiamos metodikos KDK projektuoti, nustatant sluoksnių storius pagal šių sluoksnių medžiagų kokybės rodiklius nèra.

Ypač svarbu kuo tiksliau prognozuoti kelių dangos būklès kitejjimą jos funkcionavimo laikotarpio metu, ịvertinant keliu dangos konstrukcijos sluoksnių storius, šių sluoksnių medžiagų kokybés rodiklius. Ištyrus ir ịvertinus jų kokybės rodiklius, siektina prailginti kelių asfaltbetoninès dangos funkcionavimo trukmę ir sumažinti KD remontų ir priežiūros sąnaudas. Aktualu pasiūlyti matematinius modelius, kurie leistų prognozuoti kelio dangos eksploatacinių rodiklių kitejjimą pagal KDK sluoksnių ir jų medžiagų kokybės rodiklius.

\section{Tyrimų objektas}

Tyrimų objektas - kelių dangos konstrukcijų sluoksnių rodikliai, šiems sluoksniams įrengti naudojamų medžiagų kokybès rodikliai, priemonių eismo intensyvumas ir apkrovos, $\mathrm{AB}$ dangos suirties mastas $D_{\mathrm{D}}$, funkcionavimo trukmè, provėžų gylis $H_{\mathrm{V}}$ ir $\mathrm{AB}$ dangos lygumas pagal tarptautinį rodiklị IRI $Y_{\text {IRI. }}$.

\section{Darbo tikslas}

Parengti magistralinių automobilių kelių asfaltbetoninès dangos eksploatacinių rodiklių prognozès matematinius modelius, atsižvelgiant ị tampriosios dangos konstrukcijos savybes ir transporto priemonių eismo intensyvumą. 


\section{Darbo uždaviniai}

Darbo tikslui pasiekti buvo sprendžiami šie uždaviniai:

1. Išanalizuoti automobilių kelių asfaltbetoninès (AB) dangos eksploatacinius rodiklius lemiančius svarbiausius veiksnius ir šių rodiklių blogejimo priežastis.

2. Atlikus tyrimus, nustatyti dangos $\mathrm{AB}$ komponentinès sudèties fizinių bei mechaninių ir $\mathrm{AB}$ mišiniams naudojamų medžiagų kokybès rodiklių sieti.

3. Ištirti $\mathrm{AB}$ dangos lygumo ir provèžų gylio kitejjimo dèsningumus.

4. Nustatyti dangos $A B$, kitų KDK sluoksnių medžiagų, šių sluoksnių kokybès rodiklių ir $\mathrm{AB}$ dangos lygumo bei provèžu gylio sieti.

5. Parinkti dvi racionalias magistralinių kelių tampriosios dangos konstrukcijas (skirtingam transporto priemonių (TP) eismui), ịvertinus jos sluoksniams naudojamų medžiagų kokybės rodiklius.

\section{Tyrimų metodika}

Darbe taikyti šie tyrimų metodai: grafinio modeliavimo; matematiniai analiziniai; matematinès statistikos; eksperimentiniai natūriniai automobiliu keliuose: transporto priemonių eismo intensyvumo matavimo, kelių dangos lygumo matavimo, provèžų gylio matavimo, kelių dangos suirties masto matavimo, dangos konstrukcinių sluoksnių storio nustatymo; eksperimentiniai laboratoriniai: KDK sluoksniams įrengti naudojamų medžiagų kokybės rodiklių tyrimo.

\section{Darbo mokslinis naujumas}

Mokslini naujumą rodo šie rodo šie rezultatai:

1. Pirmą kartą asfaltbetoninès dangos eksploataciniai rodikliai prognozuojami ịvertinus šiuos magistralinių kelių tampriosios dangos konstrukcijos parametrus: konstrukcinių sluoksnių faktinius storius ir šių sluoksnių medžiagu faktinius kokybès rodiklius, TP faktini eismo intensyvumą. Gauti asfaltbetoninès dangos eksploatacinių rodiklių matematiniai modeliai leidžia prognozuoti $\mathrm{AB}$ dangos višutinio sluoksnio eksploatacinius rodiklius penkerių metų laikotarpiui.

2. Ištirta kelių tiesyboje naudojamų medžiagų kokybés rodiklių tarpusavio sąveika ir jų itaka kelių dangos eksploataciniams rodikliams. 
3. Ivvertinus transporto priemonių (TP) eismo intensyvumą, ištirtas kelių dangos eksploatacinių rodiklių kitèjimas, o išanalizavus esamas kelių dangos konstrukcijų medžiagu savybes ir sluoksnių storius, pateikti kelių dangos eksploatacinių rodiklių prognozès matematiniai modeliai ir pateiktos racionalios kelių dangos konstrukcijos.

\section{Darbo rezultatụ praktinè reikšmė}

Pasiūlytos šios priemonès Lietuvos magistralinių kelių AB dangos eksploataciniams rodikliams numatyti ir pagerinti:

1. Pasiūlyti matematiniai modeliai tampriosios kelių dangos konstrukcijos (KDK) viršutinio sluoksnio eksploatacinių rodiklių prognozei atlikti. Šie matematiniai modeliai (juos taikant) leidžia, žinant KDK sluoksnių medžiagų kokybès rodiklius ir sluoksnių storius, parinkti racionalias kelių dangos konstrukcijas ir prailginti KDK funkcionavimo trukmę.

2. Prailginus KDK funkcionavimo trukmę ir jos faktinius tarpremontinius laikotarpius, bus racionaliau panaudojamos Lietuvos Respublikos biudžeto (kelių fondo ir kitos) lèšos, skirtos automobilių kelių tiesybos ir remonto darbams.

\section{Ginamieji teiginiai}

1. Tampriosios keliu dangos konstrukcijas motyvuotai sustiprinti galima žinant jų sluoksnių medžiagų kokybės rodiklius. Sustiprinus kelių dangos konstrukcijas, pailgejja jų funkcionavimo trukmè, todèl, atlikus ekonominius skaičiavimus, galima nustatyti KDK sustiprinimo ekonominę naudą.

2. Parengus kelių $\mathrm{AB}$ dangos ir jos konstrukcijų eksploatacinių rodiklių nustatymo (pagal sluoksnių storius ir jų medžiagų kokybès rodiklius) matematinius modelius, galima numatyti dangos eksploatacinių rodiklių vertes prognoziniam penkerių metų laikotarpiui.

3. Numačius kelių AB dangos eksploatacinių rodiklių labiausiai tikètinas vertes, galima pasiūlyti racionalias kelių dangos konstrukcijas. 


\section{Darbo rezultatụ aprobavimas}

Disertacijos tema paskelbta 6 moksliniai straipsniai: du - mokslo žurnaluose, itrauktuose i Thomson Reuters Web of Knowledge duomenų bazę (Bulevičius et al. 2011 (a); Bulevičius et al. 2013), trys - recenzuojamuose tarptautiniu konferencijų leidiniuose, ịtrauktuose i Thomson ISI Proceeding duomenų bazę (Bulevičius et al. 2010 (a); Bulevičius et al. 2011 (b); Bertulienè et al. 2011), vienas - tarptautinių konferencijų straipsnių rinkiniuose (Булявичюс et al. 2010 (b)).

Disertacijos tema skaityti pranešimai trijose mokslinèse konferencijose:

- 10-ojoje tarptautineje konferencijoje „Modern Building Materials, Structures and Techniques" $2010 \mathrm{~m}$. Vilniuje;

- 8-ojoje tarptautineje konferencijoje „Environmental Engineering” $2011 \mathrm{~m}$. Vilniuje;

- tarptautineje konferencijoje "Perspective Trends in Design, Construction and Maintenance of Roads, Bridges and Underground Structures" 2010 m. Minske.

\section{Disertacijos struktūra}

Disertaciją sudaro įvadas, keturi skyriai ir rezultatų apibendrinimas. Taip pat yra 4 priedai. Darbo apimtis 124 puslapiai, neįskaitant priedų, tekste panaudotos 48 numeruotos formulès, 40 paveikslų ir 18 lentelių. Rašant disertaciją panaudoti 158 literatūros šaltiniai. 


\section{1}

\section{Automobilių kelių tampriosios dangos konstrukciju su asfaltbetonine danga atliktų tyrimų analizè}

Skyriuje atlikta TP eismo intensyvumo ir sudetties Lietuvos magistraliniuose automobilių keliuose, kelių dangos būklès bei jos kitèjimo prognozès sistemų apžvalga. Išanalizuoti pasaulyje taikomi automobilių kelių dangos (KD) būklę apibūdinančių rodiklių vertinimo metodai. Apžvelgti pasaulio mokslininkų atlikti kelio dangos konstrukcijų (KDK) ir jų medžiagų savybių įtakos KD eksploataciniams rodikliams tyrimai. Pagal daugelio mokslininku atliktus tyrimus apibūdinti KD defektai ir jiems atsirasti įtaką darantys veiksniai.

Skyriaus tematika paskelbti penki autoriaus straipsniai kartu su bendraautoriais (Bulevičius et al. 2010 (а); Булявичюс et al. 2010 (b); Bulevičius et al. 2011 (a); Bulevičius et al. 2011 (b); Bulevičius et al. 2013).

\subsection{Lietuvos automobilių keliai ir jụ ivertinimas}

Lietuva turi gana tankų automobilių kelių tinklą. Magistraliniais ir krašto keliais, kurių ilgis sudaro $31,4 \%$ visų valstybinès reikšmès kelių ilgio, vežama daugiau 
kaip $80 \%$ visų krovinių (Andriejauskas et al. 2013). Valstybinès reikšmès automobilių kelių bendras ilgis $2013 \mathrm{~m}$. pradžioje sudare $21268 \mathrm{~km}$ (1.1 lentelè) (Lietuvos automobilių ... 2013). Valstybinès reikšmès automobilių kelių tinklo tankis $1000 \mathrm{~km}^{2}$ sudare $326 \mathrm{~km}$. Lietuvoje yra $575 \mathrm{~km}$ valstybinès reikšmès automobilių kelių su keturiomis eismo juostomis, iš jų $309 \mathrm{~km}$ automagistralinių. Didžiojoje dalyje Lietuvos valstybinès reikšmès automobilių kelių $(63,87 \%$ jų ilgio) paklota asfaltbetoninè ar kita asfaltinè danga (Lietuvos automobilių ... 2013) (1.1 lentelè).

1.1 lentelè. Lietuvos valstybinės reikšmės automobilių kelių tinklo struktūra (2013 m. pradžios duomenimis)

Table 1.1. The structure of road network of national significance in Lithuania (based on data of the beginning of 2013)

\begin{tabular}{|c|c|c|c|c|}
\hline \multirow{2}{*}{ Dangos tipas } & \multicolumn{4}{|c|}{ Keliai, km } \\
\cline { 2 - 5 } & magistraliniai & krašto & rajoniniai & iš viso: \\
\hline Asfaltine & 1674,64 & 4929,47 & 7291,07 & 13895,18 \\
\hline Cementbetonė & 71,12 & 0,0 & 1,37 & 72,49 \\
\hline Žvyro & 0,0 & 0,0 & 7266,91 & 7266,91 \\
\hline Grindinio & 0,42 & 0,0 & 7,20 & 7,62 \\
\hline Iš viso & 1746,18 & 4929,47 & 14566,55 & 21242,20 \\
\hline
\end{tabular}

Naudojant kelių priežiūros ir plètros programos ir ES paramos lèšas, modernizuojami Lietuvą kertantys automobilių transporto koridoriai. Pastaraisiais metais prioritetai buvo skiriami tarptautinių transporto koridorių plètrai, ìdiegiant saugaus eismo priemones. Daugiausia dèmesio skirta I ir IX transporto koridoriams, kuriuose eismo intensyvumas yra pats didžiausias. Šiais keliais vyksta intensyvus tranzito transporto priemonių eismas (Lietuvos automobilių ... 2013).

Lietuvos automobilių keliuose daugèja važiuojančių transporto priemonių (TP). Daugejant transporto priemonių $(2000 \mathrm{~m}$. - 1,29 mln., o $2013 \mathrm{~m}$. $2,24 \mathrm{mln}$.) ir jų srautuose didejant sunkiujų transporto priemonių (STP) daliai, svarbu sudaryti sąlygas saugiai ir greitai vežti keleivius ir krovinius. Turi būti garantuotos šios automobilių kelių savybès: geras dangos lygumas, nedidelis věžètumas ir maža suirtis, pakankamas KDK stipris ir gera transporto priemonių ratų sankiba su danga (Klashinsky et al. 2010; Sokolov, Sivilevičius 2011).

Transporto priemonių srauto sudètis $2012 \mathrm{~m}$. magistraliniuose keliuose buvo tokia: lengvieji automobiliai sudare $80,67 \%$ bendrojo transporto priemonių srauto, o krovininiai automobiliai - 19,33 \%, krašto keliuose lengvieji automobiliai sudare $88,09 \%$ bendrojo transporto priemonių srauto, krovininiai automobiliai - 11,91\%. Rajoniniuose keliuose lengvieji automobiliai sudarè 
$90,2 \%$, o krovininiai - 9,8\% bendrojo transporto priemonių srauto. $2012 \mathrm{~m}$. eismo intensyvumas, lyginant su 2000 m., išaugo $47 \%$.

$2012 \mathrm{~m}$. magistraliniuose keliuose, lyginant su $2011 \mathrm{~m}$., vidutinis metinis paros eismo intensyvumas (VMPEI) padidejo 0,31\%. Lengvujų automobilių eismo intensyvumas sumažèjo $0,61 \%$, krovininių automobilių eismo intensyvumas padidejo 4,31\%, o autotraukinių - 7,68\% (1.2 lentelè).

Automobilių kelių dangos tobulinimo galimybes rodo asfaltinių mišinių gamybos apimtys (Sivilevičius, Šukevičius 2009).

1.2. lentelè. Transporto priemonių srauto sudèties pokyčiai 2011-2012 metais

Table 1.2. Changes in the traffic flow composition, 2011-2012

\begin{tabular}{|c|c|c|c|c|}
\hline \multirow{2}{*}{ Keliu grupe } & \multicolumn{4}{|c|}{ VMPEI pokytis $2011 \mathrm{~m} .-2012 \mathrm{~m}}$. \\
\cline { 2 - 5 } & $\begin{array}{c}\text { bendrojo } \\
\text { transporto } \\
\text { priemoniuc } \\
\text { srauto }\end{array}$ & $\begin{array}{c}\text { lengvuju } \\
\text { transporto } \\
\text { priemonių }\end{array}$ & $\begin{array}{l}\text { krovininių } \\
\text { transporto } \\
\text { priemonių }\end{array}$ & $\begin{array}{c}\text { autotraukinių } \\
(\mathrm{krova}>12 \mathrm{t})\end{array}$ \\
\hline Magistraliniai keliai & $0,31 \%$ & $-0,61 \%$ & $4,31 \%$ & $7,68 \%$ \\
\hline
\end{tabular}

Grupuojant magistralinių kelių ruožus pagal eismo intensyvumą, nustatyta, kad daugumoje kelių ruožu (ruožų ilgių suma - 665,46 km) VMPEI buvo nuo 4000 iki 8000 aut./parą Šių ruožų suminis ilgis sudarè $38,3 \%$ viso magistralinių kelių ilgio. Kelių ruožų, kuriuose VMPEI nuo 16000 aut./parą iki 32000 aut./parą, suminis ilgis buvo $128,25 \mathrm{~km}$. Tai sudarè $7,4 \%$ viso magistralinių kelių ilgio. Kelių ruožų, kuriuose VMPEI didesnis kaip 32000 aut./para., suminis ilgis buvo $14,21 \mathrm{~km}$. Tai sudarè $0,8 \%$ viso magistralinių kelių ilgio. Likusiuose magistraliniuose kelių ruožuose VMPEI sudarè nuo 8000 iki 16000 aut/parą.

1.1 paveiksle parodytas VMPEI kitèjimas 2000-2012 metais magistraliniuose keliuose (2000 metur VMPEI prilygintas $100 \%$ ). Iš grafiko matyti, kad 2000-2008 m. eismo intensyvumas augo, 2009-2010 m. mažèjo, o nuo $2011 \mathrm{~m}$. vèl didèjo. $2012 \mathrm{~m}$. eismo intensyvumas padidejo ir, lyginant su 2000 m., išaugo 73,35 \% (Lietuvos automobilių ... 2013).

Lietuvos automobilių keliai savo eksploataciniais ir stiprio rodikliais (dangos lygumu, dangos konstrukcijos stipriu ir kt.) nėra pritaikyti atlaikyti didèjančias TP ašių apkrovas (Čygas et al. 2008; Motiejūnas et al. 2010; Laurinavicius et al. 2009). Po 1990 metų sumažejjus kelių dangos tobulinimo, taisymo ir stiprinimo darbų apimčiai, èmé blogèti jos būklè, didèti jos duobėtumas ir véžètumas mažèti kelių dangos konstrukcijos stipris (pagal jos stiprio rodiklị $S N C$ ). KDK stipris magistraliniuose ir krašto keliuose pradèjo didèti tik nuo 2004 metų (Lietuvos automobilių ... 2013). 


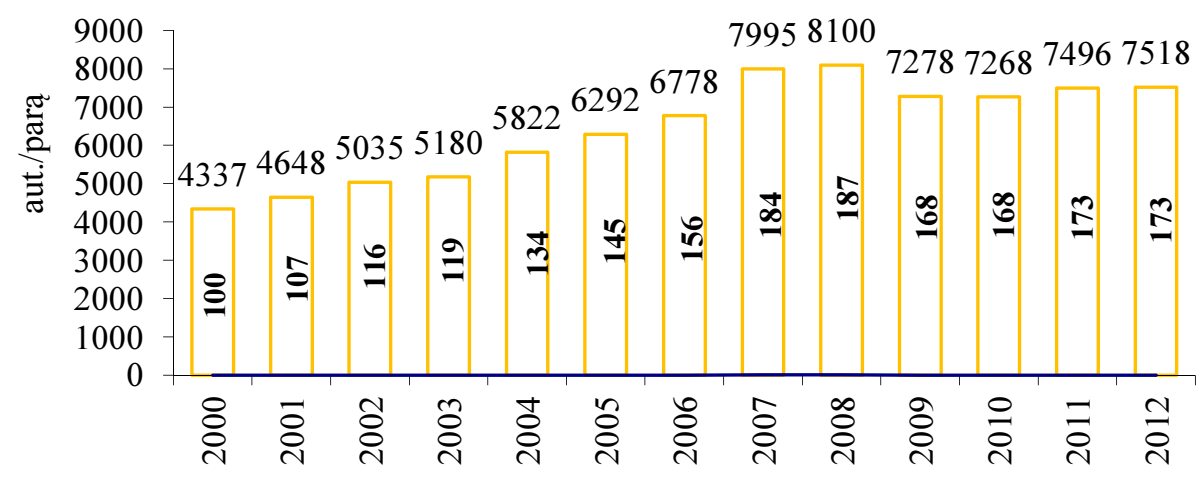

1.1 pav. Vidutinio metinio paros eismo intensyvumo kitèjimas magistraliniuose keliuose 2000-2012 metais, \%

Fig. 1.1. Change in the traffic volume of the main roads in \%, 2000-2012

Palyginus $2012 \mathrm{~m}$. ir $2003 \mathrm{~m}$. duomenis, tampa akivaizdu, kad per 9 metų laikotarpi transporto priemoniu rida magistraliniuose keliuose padidejjo $43 \%$, krašto keliuose $-32 \%$, rajoniniuose keliuose $-16 \%$. Metinè transporto priemonių rida $(2012 \mathrm{~m}$.) magistraliniuose keliuose parodyta 1.3 lenteleje. Šîs lentelès duomenys rodo, kad magistraliniuose keliuose TP rida sudaro beveik pusę (apie $47 \%$ ) visos valstybinès reikšmès keliuose vykstančios TP ridos.

1.3 lentelè. Transporto priemonių rida magistraliniuose keliuose 2012 metais

Table 1.3. The total run of vehicles on the main roads, 2012

\begin{tabular}{|c|c|c|c|}
\hline \multirow{2}{*}{ Kelių grupès } & \multicolumn{3}{|c|}{ Transporto priemonių rida } \\
\cline { 2 - 4 } & $10^{6}$ aut.km & $\begin{array}{c}\text { \% nuo bendros } \\
\text { ridos } \\
\text { magistraliniuose ir } \\
\text { krašto keliuose }\end{array}$ & $\begin{array}{c}\text { \% nuo bendros } \\
\text { ridos visuose } \\
\text { valstybinès } \\
\text { reikšmès keliuose }\end{array}$ \\
\hline Magistraliniai keliai & 4786,93 & $57,75 \%$ & $46,95 \%$ \\
\hline
\end{tabular}

Dauguma Lietuvos automobilių kelių buvo supfrojektuota ir nutiesta tuo laikotarpiu, kai galiojo 10 t. projektinè ašies apkrova, todèl pastaraisiais metais, vykstant tarptautiniam tranzitiniam krovininiu automobiliu eismui su STP ašies apkrova, sudarančia 11-13 t, o kartais 15 t (Sunkių transporto.... 2009), kelių danga ir KDK patiria pernelyg dideli ardymo poveikị (Vaitkus et al. 2010).

KD defektai blogina sunkiujų ir ypač greitai važiuojančių TP eismo sąlygas - mažina važiavimo saugumą ir patogumą (komfortą), o kartais ir važiavimo greiti (Andriejauskas et al. 2013). Sunkiosios transporto priemonès 
daro neigiamą poveikį ne tik kelių dangos lygumui, bet ir išspaudžia dangoje vėžes - šie defektai mažina eismo saugumą (Klashinsky et al. 2010; Karkowski, Rafalski 2013; Sokolov, Sivilevičius et al. 2011). Lietuvoje, kaip ir daugelyje kitų šalių, nustatyta, kad didžiausias vėžès gylis neturètų viršyti $40 \mathrm{~mm}$ (Alaa et al. 2012; Bertulienè et al. 2011; Chen et al. 2004; Dawson 2008). Kai vèžès gilesnès, kelią būtina remontuoti (KPV PN-05).

Kelių dangos vėžètumo problema egzistuoja visame pasaulyje ir tampa vis aktualesnè (Alaa et al. 2012). Praejjusio dešimtmečio viduryje (dèl lèšų stokos) tarptautiniame Via Baltica kelyje A5 ir IXB transporto koridoriuje buvo minimaliai sustiprinta kelių dangos konstrukcija. Buvo tikètasi, kad, sustiprinus KDK maždaug 10-12 metų jos nereikès remontuoti, tačiau dèl sparčiai didejančio STP eismo, praejjus septyneriems aštuoneriems metams, KDK reikia iš naujo stiprinti (Karkowski, Rafalski 2013). Pastaruoju metu, norint, kad naujai stiprinamų kelių dangos konstrukcijų ruožuose KDK funkcionuotų projekte numatytą laiką, pravartu taikyti kur kas brangesnes KDK stiprinimo technologijas, naudoti naujas medžiagas, kloti storesnius KDK sluoksnius. (Čygas et al. 2008; Laurinavicius et al. 2009; Motiejūnas et al. 2010).

Svarbiausias automobilių kelių dangos eksploatacinis rodiklis - jos lygumas (Chang et al. 2009; Harris 2013; Khattak et al. 2013; Sandra, Sarkar 2012; Petkevičius, Sivilevičius 2000). Kelių priežiūros vadovo I dalyje „Automobilių kelių priežiūros normatyvai" nurodyta, kad magistralinių kelių danga būna trijų priežiūros lygių: aukšto, vidutinio ir žemo. Šių kelių AB dangos lygumas (rodiklio $I R I$ vienetais $(\mathrm{m} / \mathrm{km})) Y_{I R I}$ pagal priežiūros lygius suskirstytas taip (KPV PN-05):

- $Y_{I R I} \leq 1,5 \mathrm{~m} / \mathrm{km}$ - aukštas priežiūros lygis;

- $Y_{I R I} \leq 2,0 \mathrm{~m} / \mathrm{km}$ - vidutinis priežiūros lygis;

- $Y_{I R I} \leq 2,5 \mathrm{~m} / \mathrm{km}$ - žemas priežiūros lygis.

Kai rodiklis $Y_{I R I} \geq 2,5 \mathrm{~m} / \mathrm{km}-\mathrm{AB}$ dangos lygumas neatitinka priežiūros reikalavimų.

Esant ịprastai (nekrizinei) šalies ekonominei paděčiai, automagistralinių ir kitų svarbiausių magistralinių kelių $\mathrm{AB}$ dangai taikomas aukštas priežiūros lygis. 2000-2006 m. išmatuotas magistralinių kelių AB dangos lygumas metams bėgant gerèjo: daugèjo ruožų, kurių $Y_{I R I}<2,5 \mathrm{~m} / \mathrm{km}$, ir mažèjo ruožų, kurių $Y_{I R I}>2,5 \mathrm{~m} / \mathrm{km}$ (Macekainis 2006) Visų magistralinių kelių AB dangos lygumo vidutinè vertè sumažejo nuo $Y_{I R I}=2,60 \mathrm{~m} / \mathrm{km}$ iki $Y_{I R I}=2,25 \mathrm{~m} / \mathrm{km}, \quad$ o automagistraliu A1 ir A2 atitinkamai nuo $Y_{I R I}=1,69 \mathrm{~m} / \mathrm{km}$ iki $Y_{I R I}=1,36 \mathrm{~m} / \mathrm{km}$ (A1) ir nuo $Y_{I R I}=1,59 \mathrm{~m} / \mathrm{km}$ iki $Y_{I R I}=1,31 \mathrm{~m} / \mathrm{km}$ (A2). Šių kelių AB dangos lygumas gereja laiku remontuojant dangą, kurios lygumo rodikliai blogiausi (Macekainis 2006). 
Lietuvai $1991 \mathrm{~m}$. atkūrus nepriklausomybę ir perèjus prie rinkos ekonomikos, isitikinta, kad iki tol naudota automobilių kelių remonto planavimo sistema, kai buvo taikomi norminiai tarpremontiniai laikotarpiai, neefektyvi, o dèl nepakankamo finansavimo ją taikyti praktiškai tapo neįmanoma. Sprendžiant ši uždavinį, buvo naudotos dangų (būklès) valdymo sistemos (DVS).

Tyrimais (Laurinavičius et al. 2010; Marzouk et al. 2012, Pradhan et al. 2001) nustatyta, kad tinkamas DVS sistemų naudojimas leidžia sutaupyti apie $20 \%$ kelių priežiūrai ir remontams skirtų lěšų.

Pritaikytos DVS sistemos leido (net gerokai sumažejus finansavimui) užtikrinti gerą valstybinès reikšmès automobilių kelių būklę ir planingai vykdyti kelių tinklo plètrą. Lietuvoje pirmiausia pradèta naudoti HDM-III sistema (Highway Desig.... 1981). Beveik tuo pat metu (1993 m.) pradèta kurti lietuviška DVS - DAVASEMA. $1994 \mathrm{~m}$. buvo sukurta kelių dangos būklès valdymo sistemos pirmoji versija. DAVASEMOJE buvo ivestas posistemis, skirtas AB dangos būklei prognozuoti. Tam buvo taikyti HDM dangu irties modeliai (Dangų valdymo.... 1997).

Ivairių veiksnių ịtaka kelių dangos irčiai dažniausia nustatoma atliekant eksperimentus ir ịvertinant empiriškai. Šie tyrimai yra brangūs ir ilgalaikiai, todèl ,kuriant DAVASEMĄ, nebuvo parengti, o buvo panaudoti kitose šalyse sukurti HDM modeliai. Visgi DAVASEMA svarbiausios nuostatos iki šiol naudojamos kelių dangos stiprinimo ir kelių rekonstrukcijos, naujų kelių tiesybos ir žvyrkelių asfaltavimo projektams ịvertinti.

Atlikti tyrimai rodo, kad kelių dangos būklè turètų būti tikrinama nuolat, siekiant objektyviai ir tiksliai nustatyti kelių dangos ir KDK remonto darbų kasmetines apimtis, o tarpremontiniai laikotarpiai (kelių $\mathrm{AB}$ dangos ir KDK funkcionavimo trukmè) periodiškai turètų būti tikslinami dèl Lietuvos keliuose kintančių eismo sąlygų: susisiekimo priemonių eismo intensyvumo, eismo sudeties ir kt.

\subsection{Automobilių kelių tampriosios dangos konstrukcijų ir asfaltbetoninès dangos būklè bei savybès}

Kelių AB dangos lygumas priklauso nuo pagrindų tipo, jų storio ir būklès, be to didelę įtaką tam turi ir naudotų medžiagų kokybès rodikliai. Dangos lygumas taip pat priklauso nuo asfaltbetonio sudèties bei struktūros ir nuo jo fiziniu ir mechaninių rodiklių (Chang et al. 2009; Harris 2013; Khattak et al. 2013; Sandra, Sakar et al. 2012; Ma et al. 2012). Kelio konstrukcijoje svarbus 
elementas žemès sankasa, kuri laiko kelią viso jos funkcionavimo laikotarpio metu (Bertulienè et al. 2010, Vaitkus et al. 2012).

Eksploatuojant kelią susidaro įvairios liekamosios deformacijos bei defektai ir dangos lygumas pradeda blogeti (Sandra, Sakar et al. 2012;). Dangos defektus galima suskirstyti $\mathfrak{i}$ šias pagrindines grupes: paviršiaus suirtis, šlyties liekamosios deformacijos, temperatūros plyšiai, nuovargio plyšiai, provėžos ir dangos skersiniai profilio iškrypiai (Khattak et al. 2013).

Vienas iš svarbiausių rodiklių, apibūdinančių kelių dangos kokybę, yra jų dangos lygumas (Harris 2013). Jis lemia važiavimo komfortą bei TP degalų sąnaudas ir užtikrina saugų eismą (Anastasopoulos et al. 2012; Anastasopoulos, Mannering 2009). Kelių dangos lygumas apibūdinamas nelygumų skaičiumi, jų vertemis ir išsidèstymu, tenkančiu kelių dangos ilgio vienetui ir dažniausiai išreiškiamas tarptautiniu lygumo rodikliui $I R I$. Keliai laikomi pakankamai geros būklès, jeigu jų dangos lygumas $Y_{\mathrm{IRI}} \leq 2,5 \mathrm{~m} / \mathrm{km}$, o ypač nelygios dangos keliais pripažįstami tie keliai, kurių dangos lygumo rodiklis $Y_{\text {IRI }} \geq 12 \mathrm{~m} / \mathrm{km}$ (Chang et al. 2009; Harris, 2013).

Dangos lygumas, naudojant primityvias matavimo priemones (kartelę), buvo pradètas matuoti dar $1900 \mathrm{~m}$. Sudètingesni kelio išilginio profilio matavimo įrenginiai (profilografai, mobilieji matavimo prietaisai) buvo sukurti ir pradèti diegti 1950-1960 metais. Kelius prižiūrinčios įmonès naujai ịrengtos dangos lygumą pradèjo tikrinti 1960-1980 m., tačiau 1980-1990 m. tai pradèta taikyti visame pasaulyje (Wang 2006). Anksčiau išvardyta matavimo įranga ir matavimo būdai gali būti suskirstyti ì penkias pagrindines grupes (Perera, Kohn 2012):

- matavimas rankinèmis preimonèmis (lygi matuokle ir gilmatis, kartelè su gylio matavimo pleištu, mobilioji lygumo matavimo kartelè),

- matavimas pusiau automatinèmis matavimo priemonèmis (pusiau automatinis profilografas),

- matavimas automatiniais lygumo matavimo ir fiksavimo prietaisais (Bureau of public roads (BPR) ir Portland Cement Association (PCA) lygumo matavimo prietaisai ir $\mathrm{kt}$.),

- automatiniais greitaeigiais lygumo matavimo prietaisais (mobilioji laboratorija RST-28, DYNATEST 5051 RSP, automatinis kelio analizatorius T6600 ir kt.),

- lengvaisiais profilometrais (lengvasis paviršiaus analizatorius (LISA) 6200, CS8700, DYNATEST/KJL 6400 ir kt.).

Naudojami ir kiti kelių dangos lygumo nustatymo metodai. Atsižvelgiant $\mathfrak{i}$ eksploatacinius reikalavimus, kelių dangos lygumą siūloma vertinti smūgių kiekiu kelio kilometre. Didžiosios Britanijos transporto ir keliu tyrimų laboratorija daugelį metų dangos lygumo tyrimams naudojo profilografus, pagal 
kurių grafogramas nustatinejjo nelygumų aukščių sumą matuojamame ruože, $\mathrm{mm} / \mathrm{km}$. Buvo apytiksliai nustatyta šių nelygumų charakteristikų ir tarptautinio lygumo rodiklio sietis (Guidelines of ... 2009):

$$
\begin{gathered}
n_{T}=13 Y_{\mathrm{IRI}}, \\
n_{h}=630 Y_{\mathrm{IRI}}{ }^{1,12} .
\end{gathered}
$$

čia $Y_{\text {IRI }}$ - tarptautinis lygumo rodiklis $Y_{\mathrm{IRI}}, \mathrm{m} / \mathrm{km}, n_{\mathrm{T}}-$ smūgių skaičius, užregistruotas viename kilometre smūgiamačiu, $n_{\mathrm{h}}$ - profilografo rodiklis nelygumų skaičių suma, $\mathrm{mm} / \mathrm{km}$.

Esant ilgiems kelio ruožams, lygumo pokyčių matavimai nenašiais (kartele ir gulsčiuku bei kitais) rankiniais prietaisais mažai efektyvūs. Mokslininkai Lietuvoje ir užsienio šalyse atliko eksperimentinius matavimus ir įrodè, kad IRI vertès matuojant mobiliaisiais prietaisais, artimai koreliuoja su rankiniais prietaisais išmatuotomis vertemis (Múčka 2012; Petkevičius et al. 2009; Petkevičius, Sivilevičius 2008). Tarptautinio lygumo rodiklio IRI matavimus atlikti trumpuose kelio ruožuose ar uždarose patalpose, naudojant dabartines mobiliąsias laboratorijas, kartais būna sudètinga arba ekonomiškai nenaudinga. Šiuos matavimus MingHsin technologijos ir mokslo universitetas (Taivanas) siūlo atlikti naudojant automatinę IRI matavimo įrangą (robotą) P3-AT, kurio tikslumas, matavimus atliekant $50 \mathrm{~m}$ ilgio kelio ruože nukrypo $\leq 0,02 \mathrm{~m} / \mathrm{km}$, lyginant su mobiliojo profilografo išmatuotomis IRI vertemis (Chang et al. 2009).

Pastaraisiais metais kelių dangos lygumui įvertinti dažniausiai naudojami automobiliai, kuriuose sumontuota aparatūra, registruojanti automobilio reakciją i nelygumus - tai smūgiamatis, matuojantis santykinius pakabos poslinkius tarp ašies ir automobilio korpuso. Juo galima tiksliai išmatuoti kelio lygumo rodiklio $I R I$ vertę ir nesunkiai apdoroti gautus matavimų duomenis (Múčka 2012, 2013;). Smūgiamačiai montuojami lengvuosiuose automobiliuose arba priekabose su vienu ar dviem ratais.

Vadovaujantis „Automobilių kelių investicijų vadovu“, patvirtintu LAKD, rengiant investicinius projektus, dangos būklę charakterizuoja šie veiksniai:

- keliu dangos lygumas;

- asfaltbetoninès dangos ịlinkiai;

- TP ratų sankibos su danga koeficientas.

Kelių dangos lygumas matuojamas IRI (tarptautinio lygumo rodiklio) vienetais, $\mathrm{m} / \mathrm{km}$. Lygumas matuojamas kas $50 \mathrm{~m}$ kiekvienoje eismo juostoje (Andriejauskas et al. 2013). Ruožo lygumas nustatomas taip (Perera, Kohn 2012):

$$
I R I=\frac{1}{n} \times \frac{1}{l} \sum_{i=1}^{n} \sum_{j=1}^{i} I R I_{i j}
$$


čia $I R I$ - ruožo vidutinis lygumas, $\mathrm{m} / \mathrm{km}, n-50 \mathrm{~m}$ ilgio elementariujų kelio ruožų skaičius, $l$ - eismo juostų skaičius, $I R I_{\mathrm{ij}}$ - i-tojo elementariojo kelio ruožo $j$-ojoje eismo juostoje KD nelygumas $I R I$ vienetais, $\mathrm{m} / \mathrm{km}$.

Kelių asfaltbetoninès dangos lygumas matuojamas 1-os klasès nelygumų matavimo įrenginiu. Šiuo metu Lietuvos valstybinès reikšmès kelių asfaltbetoninès dangos lygumas matuojamas lazeriniu profilometru DYNATEST 5051 RSP. Pagal technines prietaiso charakteristikas matavimai atliekami esant aukštesnei nei $+5{ }^{\circ} \mathrm{C}$ temperatūrai. Asfaltbetoninès dangos lygumo matavimo sezonas apibrèžtas kelių priežiūros ir valdymo sistemoje, t. y. dangos lygumas matuojamas tik tada, kai jau būna ištaisyti dangos defektai (Šiaudinis, Cygas 2007). Nuo $2007 \mathrm{~m}$. keliu dangos lygumas (svarbiausiuose keliuose) matuojamas naudojant kelių laboratoriją RST-28 (Cygas et al. 2011; Dimaitis 2008).

Ilinkiams matuoti Lietuvos automobiliu kelių direkcija, kaip ir plačiai pasaulyje (Deblois et al. 2010), naudoja krintančio svorio deflektometrą DYNATEST 8000 FWD. Krintančio svorio deflektometru išmatuoti ịlinkiai leidžia ịvertinti esamų kelių dangos konstrukcijų stipri ir apskaičiuoti kelių dangos konstrukcijų modifikuotą stiprio rodiklị (SNC) (Šiaudinis, Cygas 2007).

Kelių asfaltbetoninès dangos defektai vertinami orginoleptiniu tyrimu. Toliau pateikti vizualiujų apžiūrų metu vertinami asfaltbetoninès dangos defektai:

- plyšiai;

- lopai ir duobès;

- paviršiaus deformacija;

- dangos lukštenimasis;

- kelkraščių lūžinejjimas;

- kiti defektai.

Vizualiujų apžiūrų metu dangos defektai ir jų vertès nustatomi naudojant "Automobilių kelių remontų planavimo normatyvus", kuriuose nurodytos defektų leidžiamosios vertès ir jų vertinimas (KPV PN-05).

\subsection{Kelių tampriosios dangos konstrukcijų sluoksnių medžiagos ir jų savybès}

Kelių dangos ir KDK funkcionavimo trukmè ir patikimumas priklauso ne tik nuo dangos asfaltbetonio sudeties, bet ir nuo jo sutankinimo laipsnio, pradiniu medžiagų, naudotu konstrukcijos sluoksniams įrengti, kokybès, sluoksnių storio ir kitų veiksnių (Butkevičius et al. 2007; Sivilevicius, Vislavicius 2008). Labai 
sunku prognozuoti realią asfaltbetoninès dangos ir jos konstrukcijos realią funkcionavimo trukmę, priklausomai nuo asfaltbetonio sudeties ir jo fizinių bei mechaninių ar kitų savybių (Bulevičius et al. 2010 (a), 2013).

Daugelio autorių irodyta, kad asfaltbetonis yra kompozitinè medžiaga, kurioje pasireiškia tampriosios, klampiosios ir plastiškosios jo savybės (Mučinis et al. 2009; Petkevičius et al. 2009; Petkevičius Sivilevicius 2008; Radziszewski 2007; Sivilevičius et al. 2011, 2008 Ferne 2006; Vislavicius et al. 2013). Taip pat jis apibūdinamas stipriu (Butkevičius et al. 2007). Kompozitai - medžiagos, sudarytos iš dviejų ir daugiau ivvairios kilmès medžiagų, kurios pasižymi savybėmis, skirtingomis nei pradinès medžiagos. Kompozitus sudaro kaupiklis (dispersinè fazè) ir rišiklis (matrica). Itempių deformacijos būvio tyrimai rodo, kad kompozitu savybès gali būti ịvairios - jie gali būti ir tampriomis, ir plastiškomis, ir rišamosiomis medžiagomis. Matrica priima apkrovą, o dispersinè fazè trukdo susidaryti deformacijai bei suteikia tvirtumo. Platų kompozitinių medžiagu paplitimą lemia jų pranašumas prieš tradiciškai daugelyje sričių, įskaitant ir kelius, naudojamas medžiagas. Pranašumas yra tas, kad nors kompozito (asfaltbetonio) stipris gali būti mažesnis už, pavyzdžiui, mineralinio užpildo stiprį, tačiau, vertinant tamprumą ir ilgaamžiškumą, kompozitinè medžiaga yra gerokai pranašesnè (Ceylan et al. 2008; Ceylan et al. 2009).

Tyrimai rodo, kad asfaltbetonio tąsiosios ir tampriosios savybès labiausiai išryškèja žiemą. Pavasarį ir rudenį asfaltbetonis daugiausia reiškiasi kaip tamprus ir plastiškas, o vasarą - kaip klampusis, tamprus ir plastiškasis kūnas. Asfaltbetonio savybių kitejimas bėgant metams labiausiai priklauso nuo vietovès, kurioje ịrengtas kelias, hidroterminio rèžimo, taip pat nuo TP automobilių ratų apkrovų. Kai TP greitis būna didesnis kaip $10-15 \mathrm{~km} / \mathrm{h}$, rišamosios asfaltbetonio savybės pasireiškia nedaug. Atsižvelgiant ị vienų ar kitų medžiagų savybių raiškos lygi, vyksta ịvairūs kelių dangos irties procesai (Gui, et al. 2007; Petkevičius et al. 2010).

Nustatant asfaltbetonio kokybès rodiklių $(K)$ atitikti reikalavimams, gali būti trijų tipų nelygybès su vienpusėmis arba dvipusemis ribomis (apatinè $T_{a}$ ir viršutinè $T_{v}$ ) (Petkevičius 2008):

$K<T_{v}$ (rodikliams $R_{0}, H, K,{ }_{1}, P_{l} / P_{2}\left(\right.$ kai $\left.\mathrm{t}=+50^{\circ} \mathrm{C}\right)$ ),

$K>T_{a}\left(\right.$ rodikliams $R_{20}, R_{50}, K v, R_{b} E, K_{s}, P_{i} / P_{2}\left(\right.$ kai t $\left.=-10^{\circ} \mathrm{C}\right)$ ),

$T_{a}<K<T_{v}$ (rodikliams $W, L P, S K, S M, M M, B, B / M M$ ).

čia $K_{\mathrm{s}}, L P$ - atitinkamai asfaltbetonio tankio koeficientas ir liekamasis poretumas; $S K, S M, M M, B$ - atitinkamai grūdelių, stambesnių kaip $2 \mathrm{~mm}$ (skaldos), 0,09-2 mm stambumo (smèlio), smulkesnių kaip 0,09 mm (mineralinių miltelių) ir bitumo kiekiai asfaltbetonyje, masès \%.

Tikslinant fizinius ar mechaninius asfaltbetonio rodiklius, pravartu įrodyti, kad kiekvienas iš jų modeliuoja tam tikrą asfaltbetonio atliekamą funkciją kelių 
dangoje. Jeigu du ar daugiau rodiklių modeliuoja vieną ir tą pačią asfaltbetonio atliekamą funkciją kelių dangoje, reikia silpniau koreliuojančių su dangos eksploatacinėmis savybėmis rodiklių visiškai atsisakyti, paliekant tik geriausiai jos darbą (funkcijas) modeliuojantį rodikli. Reikia atsisakyti ir tokių nedubliuotų rodiklių, kurie silpnai modeliuoja tam tikro pobūdžio dangos darbą. (Petkevičius, Sivilevičius 2000; Kim et al 2003, 2005; Ker et al 2008;).

Labai svarbus asfaltbetoninès dangos kokybès rodiklis yra jos vienodumas pagal sudètị ir struktūrą bei fizinius ir mechaninius rodiklius. Irodyta, kad užtikrinus reikiamą asfaltbetoninès dangos vienodumą pagal sudèti, tuo pačiu metu užtikrinamas ir reikiamas jos vienodumas pagal fizinius ir mechaninius rodiklius (Sivilevičius, Vansauskas 2013).

Tyrimais irodyta, kad KDK stiprio mažejjimas - tai gana sudètingas procesas, kuri galima apibūdinti ịvairiais determinuotais fiziniais suirties modeliais. KDK irtis priklauso nuo keliu $\mathrm{AB}$ dangos bei jos konstrukcijos sluoksnių medžiagu savybių ir jų kitejjimo KDK funkcionavimo laikotarpio laikotarpiu. Ji apibūdinama keturiomis pagrindinèmis reologinèmis $\mathrm{AB}$ savybemis: tamprumu, plastiškumu, tąsumu ir stiprumu. Pastaruoju metu kelių $\mathrm{AB}$ dangos ir KDK stiprio mažejimas nustatomas įvertinant jos eksploatacinių rodiklių, nuo kurių priklauso TP srauto kelyje greitis, eismo saugumas ir važiavimo patogumas, kitejimą. KDK stiprio kitejimas nustatomas pagal jos standumo (kelių dagos tampriojo įlinkio) kitejjimą - tai labai apibendrintas apibūdinimas, o mažiausias jos stipris îvertinamas tik projektiniu metų laikotarpiu (Petkevičius, Sivilevičius 2008).

Labiausiai paplitusios žemès sankasos liekamosios deformacijos nuosèdžiai. Dèl ịšalo žemès sankasos gruntų tūris padidejja, o polaidžio metu sumažèja, tačiau ne visur vienodai. Kai pylimai nusėda nedaug, KDK pavojus negresia, tačiau nevienodai ir labai nusėdę mažuose pylimo plotuose gruntai gali dangoje sukelti pavojingus ribinius įtempius ar net ją suardyti.

Taip pat gali būti deformuota ir kuri nors kita žemès sankasos dalis: nušliuožti šlaitas arba nusèsti kelkraštis. Šios šlaitų liekamosios deformacijos būna dažnos, kai būna statūs ir supilti iš nevienodų bei blogai sutankintų gruntų šlaitai. To priežastimi dažniausiai būna padidejjusios transporto priemonių apkrovos ar per daug ịmirkę žemès sankasos gruntai.

Defektais ir suirtimi gali būti pažeista tiktai kelių danga ir/ar visa kelių dangos konstrukcija. Dažniausiai pasitaikantys $\mathrm{AB}$ dangos defektai ir suirtis (Petkevičius, Sivilevičius 2008):

- nuodyla - dažniausia dangos suirtis;

- išaižos - dangos paviršiaus mineralinių grūdelių apsinuoginimas ir nubyrëjimas; 
- ištrupos - einanti po išaižų dangos irties fazè - tai suirtis, kai nuo AB dangos atsiskiria stambesnieji mineraliniai grūdeliai, jie būna nuo kelių iki $20 \mathrm{~mm}$ stambumo;

- kraštų ịlūžiai - AB dangos suirtis jos sąlyčio su kelkraščiu vietose, kai kelkraščiai ịrengti iš kitos nei danga medžiagos (skaldos, žvyro ir kt.);

- išdaužos (duobès) - nuo 20 iki $100 \mathrm{~mm}$, o kartais ir didesnio gylio vienetiniai suirties dariniai, atsirandantys dèl nepakankamos mineralinių medžiagu ir organinių rišiklių sankibos, taip pat dèl šių medžiagu nepakankamo tankio ir kitų priežasčių;

- šlyties liekamosios deformacijos - tai defektai, atsirandantys dideli plastiškumą turinčioje $\mathrm{AB}$ dangoje;

- šlyties liekamosios deformacijos - provėžos, susidarančios $A B$ danga važiuojant TP ratams;

- plyšiai - labai dažni kelių asfaltbetonio dangos defektai, jie būdingi ir cementbetoninei (betoninei) dangai.

Didžiausią ịtaką kelio funkcionavimo trukmès prailginimui turi bitumo savybès ir teisingai parinktas bitumas (jo tipas), geriau ar blogiau atitinkantis KDK funkcionavimo sąlygas. Bitumo savybès gerinamos tobulinant jo gamybos technologijas, išgaunant ji iš naftos žaliavos ir ịterpiant ịvairius priedus. Priedai įterpiami i pagamintą bitumą arba sudozuojami jo gamybos metu. İterpus priedus, pagerinama bitumo sankiba su mineralinèmis medžiagomis, padidinamas bitumo elastingumas, plastiškumas ir stabilumas, veikiant įvairiems eksploataciniams veiksniams.

Kelių asfaltbetoninès dangos kokybès rodikliams didelę įtaką turi ne tik naudojami bituminiai rišikliai, mineraliniai milteliai ir kiti komponentai, bet ir naudojamos skaldos fizinès, mechaninès bei geometrinès savybès (Petkevičius et al. 2009). Autoriu darbuose (Timm, Newcomb 2006; Merilla et al. 2006; Loizos 2006) parodyta kad, tinkamai suprojektavus ir ịrengus nestandartinę kelių dangą ir kelių dangos konstrukciją (KDK), danga ilgą laiką (10-20 metų ir ilgiau) išlieka lygi ir būna, mažai pažeista defektais (Amšiejus et al. 2009, 2010).

Atliktų darbų (Lundstrom et al. 2004; Choi, Bahia 2004; Kim et al. 2005; Tighe et al. 2007; Lee et al. 2007; Butkevičius et al. 2007; Ahammed, Tighe 2008; Li et al. 2008) analizé parodè, kad AB danga ir KDK funkcionuoja labai sudètingomis, nuolat kintančiomis sąlygomis ir veikiant dažnai pasikartojančioms TP apkrovoms. Šių apkrovų poveikio trukmè, pasikartojimo dažnis ir dydis nuolat kinta, todèl intensyviojo sunkiųjų TP eismo keliuose KDK sluoksniams naudojamos mineralinès medžiagos, geriausiai atitinkančios KDK funkcionavimo sąlygas.

Akmens medžiagos ir iš jų įrengti KDK sluoksniai jau daugelị metų tiriami Rusijoje (Иваньски 2003). Šie tyrimai nemaža skirti priklausomybėms tarp 
medžiagu stambumo, granuliometrinès sudèties bei stiprio rodiklių ir šių medžiagų tampros modulių tikslinti. Šie tyrimai buvo tęsiami Rusijoje ir Baltarusijoje. Skalda taip pat naudojama ir pagrindo mišiniams gaminti. KDK sluoksniuose esanti medžiaga yra veikiama statine arba dinamine, pastoviaja, kintamaja, arba cikline apkrovomis. AB dangą ardo temperatūros pokyčiai, krituliai ir kiti klimato bei aplinkos veiksniai. Nuo skaldos savybiu priklauso asfaltinio mišinio gamybos būdai, KDK sluoksnių storiai ir kiti KDK ypatumai. Parenkant skaldą, reikia išanalizuoti KDK funkcionavimo sąlygas (apkrovas ir klimato bei aplinkos veiksnius), taip pat - KDK keliamus eksploatacinius reikalavimus. Tada parenkama skalda, geriausiai funkcionuojanti KDK esamomis eksploatacinèmis sąlygomis (Bulevičius et al. 2010a, 2010b).

Lenkijoje (Иваньски 2003) ir Rusijoje atlikti įvairių mineralinių medžiagų (kvarco bazalto skaldos bei îvairios kilmès (uolienų) susmulkintu smèlio frakciju) įtakos skaldos ir mastikos asfaltbetonio savybėms tyrimai. İrodyta, kad $\mathrm{AB}$ savybès labai priklauso ne tik nuo ịterpiamų paviršius aktyvinamujų priedų (PAP), bet ir nuo naudojamų mineralinių medžiagų kilmès (jų uolienų savybių). Darbe (atlikus eksperimentinių tyrimų analizę) nustatyta skaldos sluoksnio, irengto užkyliavimo būdu, tampros modulio ir liekamojo akytumo glaudi koreliacinè sietis (determinacijos koeficientas $R^{2}=0,916$ ), taip pat - šio sluoksnio tampros modulio ir jo tankio (sutankinto būvio) glaudi koreliacinè sietis $\left(R^{2}=0,991\right)$.

Skaldos, naudojamos asfaltinių mišinių gamybai, svarbiausi geometriniai rodikliai tai jos granuliometriné sudetis, trupintujų ir skaldytujjų dalelių santykinis kiekis ( $C_{\mathrm{c}}->50 \%$ skelto paviršiaus, $C_{\mathrm{tc}}->90 \%$ skelto paviršiaus, $C_{\mathrm{r}}->50 \%$ apvalaus paviršiaus, $C_{\mathrm{tr}}->90 \%$ apvalaus paviršiaus) ir pailgu dalelių santykini kieki rodantys dalelių plokštumo FI bei formos SI rodikliai. Visi šie rodikliai turi įtakos projektuojamo asfaltbetonio stipriui bei tvarumui (Butkevičius et al. 2007; Bulevičius et al. 2013; Bennert et al. 2011; Komba et al. 2010; Markauskas et al. 2010; Moaveni et al.2013).

Defektai, atsirandantys kelių dangoje dèl sunkiujų transporto priemonių poveikio, turi ịtakos kelių dangos funkcionavimo trukmei, važiavimo patogumui ir saugiam eismui. Gerinant kelių dangos savybes ir TP eismo sąlygas, Lietuvos ir kitu šalių mokslininkai atlieka kelių dangos konstrukcijų sluoksnių tyrimus, analizuoja šių sluoksnių savybių įtaką eksploataciniams kelių dangos rodikliams, asfaltinių mišinių, naudojamų kelių dangos konstrukcijų sluoksniams, fizikines ir mechanines savybes ir kt. Mineralinès (granito, dolomito, žvyro) medžiagos skiriasi savo stambumu, forma ir funkcionavimo sąlygomis keliuose, kurios priklauso nuo TP apkrovų dydžio ir pobūdžio, aplinkos temperatūros, jos agresyvumo ir kt. Šios medžiagos KDK sluoksniuose būna veikiamos statine ir/ar dinamine, taip pat pastoviaja, kintamaja arba cikline apkrovomis. Aplinkos temperatūra gali būti žema arba aukšta, o pati aplinka - neutrali arba agresyvi. 
Minderalinių medžiagų, naudojamų asfaltinių mišinių gamybai, fizinès ir mechaninès savybès turi ịtakos kelių dangos konstrukcijų kokybės rodikliams, t. y. patikimumui ir laikiškumui. Nuo fizinių ir mechaninių savybių priklauso mineralinių medžiagų tinkamumas asfaltiniam mišiniui. Nuo mineralinių medžiagų savybių priklauso asfaltinių mišinių gamybos būdai, kelių dangos konstrukciju sluoksnių storiai ir kiti KDK ypatumai. Parenkant mineralines medžiagas reikia išanalizuoti kelių dangos konstrukcijų funkcionavimo sąlygas (TP apkrovas, vietos sąlygas, klimatą, eksploatacinius reikalavimus KDK) Parenkamos mineralinès medžiagos, geriausiai atitinkančios esamas KDK funkcionavimo sąlygas. Mineralinių medžiagu parinkimas (konkretiems atvejams) turi būti ekonomiškai pagrịstas. Naudojant didesnio stiprio mineralines medžiagas pailgèja kelių dangos konstrukcijos funkcionavimo trukmè, ji būna patikimesnè, būna plonesni atskiri kelių dangos konstrukcijos sluoksniai ir mažesnès mineralinių medžiagų ir kitų medžiagų sąnaudos (AASHTO, Quide...1993; Petkevičius, Sivilevičius 2000; Skrinskas et al. 2011; Al-Quady et al. 2002; Butkevičius 2007; Bhasin et al. 2009; Bulevičius et al. 2011a, 2011b).

Lietuvoje pirmą kartą išmatuotas asfalto dangos konstrukcijų plastinių deformacijų susidarymas ir vystimasis, vertinant natūralias aplinkos sąlygas. Tyrimai buvo atlikti matuojant unikalų, $2007 \mathrm{~m}$ ịrengtą, 12-kos skirtingų asfaltinès dangos konstrukcijų kelio ruožą eksploatuota 5 metus identiškomis sąlygomis: esant vienodai TP eismo apkrovai, klimatinėms salygoms bei dangos konstrukcijų hidroterminiam rèžimui. Atlikus tyrimą nustatyta, kad kelią eksploatavus 5 metus ir pravažiavus 310000 sunkiojo transporto (ST) srauto ekvivalentių standartinių $100 \mathrm{kN}$ ašių skaičiui konstrukcijos laikomoji geba yra pakankama, o provèžų gylis tiesiogiai priklauso nuo asfalto viršutinio sluoksnio savybių (Čygas et al. 2008, 2011; Laurinavicius, et al. 2009; Vaitkus et al. 2009, 2010; 2012; Žiliūtė et al. 2013). Tačiau nebuvo nustatytas kelio dangos eksploatacinių rodiklių: lygumo $Y_{\text {IRI }}$ ir pažaidų mąsto $D$ kitejjimas bei jų saveika su atskirų KDK sluoksnių bei jų medžiagų savybėmis

\subsection{Transporto priemonių eismo ir klimato bei vietos sąlygų ịtaka kelių tampriosios dangos konstrukcijoms}

Automobilių kelių konstrukcijas (KK) sudaro KDK ir žemès sankasa (ŽS), dangos konstrukciją - dangos ir pagrindo sluoksniai. Žemès sankasa - tai dangos konstrukcijos pagrindas. Dangos pagrindas turi priimti ir atlaikyti transporto priemonių eismo ir dangos sluoksnių apkrovą bei ją tolygiai paskirstyti žemès 
sankasoje. Jis turètų būti vientisas ir stabilus. Lietuvoje techniškai tinkama kelių danga ir KDK, atsižvelgiant i paskirti, transporto priemoniu apkrovas, vietos gruntus ir drékinimo sąlygas, parenkama pagal kelių techninį reglamentą „Automobilių keliai“ (KTR 1.01:2008) ir Dangu konstrukcijų projektavimo taisykles (KPT SDK 07).

Kai $A B$ dangą ir visą tampriosios dangos konstrukciją veikiančios daugkartinès apkrovos, perduodamos per TP ratus, atitinka KDK projektini stipri, dangoje ir jos konstrukcijoje pasireiškia tik tampriosios deformacijos. Jeigu keliu važiuoja TP, kurių apkrova viršija projektinę apkrovą, taip pat, kai žemès sankasos grunto atsparumas labai sumažeja pavasari ar rudeni, atsiranda nežymių plastinių deformacijų, o kai šių deformacijų sankaupa didžiausio dangos susilpnejjimo metu viršija tam tikrą leistinają jų sankaupos ribą, AB dangoje ir KDK atsiranda defektų. Kai TP apkrovos kartojasi, šie defektai plečiasi bei dideja ir danga gali pradèti intensyviai irti - dangoje gali atsirasti plyšių, taip pat ištrupų, išdaužų ir kitų pažaidų (Puodžiukas 2000; Yu 2005; Jongvon, Sandhyeok 2006; Petkevičius, Sivilevičius 2008). Automobilių ratų apkrovoms veikiant kelio dangos konstrukciją, KDK įlinksta. Šis įlinkis parodo KDK atsparumą (apibūdina jos tamprą ir stiprị). Kuo didesnis kelio dangos konstrukcijos tampros modulis, tuo tolygiau TP ratų apkrovos (ir dèl jų susidarę itempiai) pasiskirsto KDK sluoksniuose (Castro, Sanchez 2007; Petkevičius, Sivilevičius 2008).

Pažaidų daugejimą kelių dangoje lemia kelių dangos tipas, panaudotos medžiagos bei šių medžiagų, esančių kelio dangos konstrukcijoje, kokybė ir savybių (per tam tikrą laiką) kitejimas, KDK irengimo technologija, aplinkos veiksniai, transporto priemonių eismo intensyvumas bei sudètis (STP dalis iš bendro srauto, \%), kelių dangos konstrukcijos stiprio (laikui bėgant) mažejimas, kelių dangos remontas ir KDK sustiprinimas (atliekamas laiku ar paveluotai). Charakteringos kelių dangos asfaltbetonio (AB) pažaidos dažniausiai būna šlyties ir kitos plastinio pobūdžio liekamosios deformacijos, skersiniai (temperatūros ịtakos) ir nuovargio plyšiai, erozija, o vèliau - išdaužos. Didžiają jų dalị sudaro nuovargio plyšiai (dèl STP dangai poveikio). Kiekvienos skirtingo pobūdžio pažaidos dalis (\%) suirusioje dangoje priklauso nuo kelio kategorijos, kelių dangos konstrukcijos stiprio, konstrukcinių sluoksnių storio, STP eismo intensyvumo $N_{s}$ bei vietovès gruntų, klimato ir drékinimo sąlygų (Sivilevičius, Petkevičius 2010).

Veiksniai, sukeliantys kelių dangos irti, yra tarpusavyje susiję, todèl pagal defekto tipą dažniausiai sunku nustatyti, kokia būna konkreti suirties priežastis bei kurie veiksniai turi didžiausią ịtaką susidaryti defektui ir didèti jo apimčiai (plotui). Svarbiausi rodikliai, paaiškinantys defektų susidarymo kelių dangoje priežastis: per silpna kelių dangos konstrukcija, pernelyg didelis ardomasis TP apkrovų kelių dangai ir jos konstrukcijai poveikis, nepalankios vietovès klimato ir 
drèkinimo sąlygos, jautrūs šalčiui žemès sankasos gruntai (Petkevičius, Sivilevičius 2000; Braga 2005; Cygas et al. 2007; Guide lines ... 2009).

Darbu (Yu 2005; Jongvon, Sandheyok 2006) analizè parode, kad, tiesiant automobilių kelius, daugeli metų buvo taip projektuojama KDK, kad tam tikrą (projektinị ar numatytą) laikotarpi, ịvertinant STP poveikị kelių dangai ir KDK, būtų užtikrintas reikiamas KDK stipris. Šio tikslo buvo siekiama ne tik įrengiant pakankamo stiprio AB dangą, bet ir daug demesio skiriant pagrindo sluoksnių medžiagų stipriui.

Darbu (Puodžiukas 2000; Petkevičius, Podagèlis 2000; ОДН 218.046-01 Yu 2005; Jongvon, Sandheyok 2006) analizè parodè, kad, apibūdinant kelių dangos ir KDK būklę, būtina žinoti jų eksploatacinius rodiklius. Svarbiausi kelių dangos ir jos konstrukcijos rodikliai, nuo kurių priklauso KD ir KDK funkcionavimo trukmè, yra šie:

- kelių dangos ir KDK stipris;

- KDK monolitinių sluoksnių atsparumas tempimui lenkiant ir jų atsparumas šlyčiai;

- KDK nerišliujų sluoksnių atsparumas šlyčiai;

- dangos lygumas;

- dangos nuodyla;

- automobilių ratų sankiba su kelių danga;

- automobilių kelių dangos apkrovų pobūdis (didžiausiosios apkrovų vertès, apkrovų kartojimosi dažnis) ir kt.

Šių darbų ir darbo De Solminihac et al. (2003) rezultatų analizè parodè, kad kelių dangos ir KDK funkcionavimo trukmè gali kitèti nuo transporto priemonių eismo sudèties ir intensyvumo, klimato sąlygu, dangos ir KDK stiprio bei jos sluoksnių storio, dangai ịrengti naudojamų medžiagų kokybès ir daugelio kitų veiksnių. Apie racionalų kelių dangos ir KDK funkcionavimo trukmès naudojimą sprendžiama pagal dangos eksploatacinių rodiklių atitiktị transporto priemonių (TP) eismo poreikiams.

Chen et al. (2004) teigia, kad po KDK esantis žemès sankasos (ŽS) gruntas nuolat slegiamas virš jo esančių KDK sluoksnių ir TP apkrovų, todèl šio grunto atsparumas apkrovoms lemia kelių dangos stabilumą ir lygumą.

De Solminihac et al. (2003) nustaté, kad dèl kelių dangos ir kai kurių kitų KDK sluoksnių medžiagų ir žemès sankasos grunto tąsumo, kelių dangos irtis vyksta lèčiau. Šiuo atveju KDK ilinkis, visiškai atitinkantis pridètają apkrovą, pasiekiamas ne iš karto, o praejjus keletui minučių.

Daugelis autorių (Petkevičius, Podagèlis 2000; Hu et al. 2008a, 2008b; Petkevičius 2008, 2010; Loria et al. 2008; Perera, Khon 2012) nurodè, kad STP ardomasis poveikis vertinamas taikant asfaltbetonio sluoksnių atsparumo plyšiams kriterijų, nes, važiuojant sunkiosioms transporto priemonèms, kelių 
asfaltinejje dangoje labiausiai pasireiškia nuovargio plyšiai. Asfaltbetonio sluoksnių ịvairaus pobūdžio pažaidos (nuovargio plyšiai, provėžos, įdubos, pralaužos, skersiniai plyšiai, įstrižieji plyšiai, išaižos, ištrupos, išdaužos ir kt.) susidaro dèl daugkartinio išorès jègu ir (arba) aplinkos temperatūros, saulès spinduliuotès, taip pat vandens, sniego, ledo poveikio, todèl, įvertinant kelių dangos suirties mastą, nustatomi kelių tiesybos medžiagų ir (arba) gruntų funkcionavimo dangoje, kai veikia kartotinès apkrovos, dèsningumai.

Apkraunami (patiriantys apkrovas) AB dangos sluoksniai skersine kryptimi tempiami labiau nei išilgine, todèl, esant daugkartiniam dažnam automobilių ratų poveikiui, pirmieji išilginiai plyšiai susidaro automobilių ratų labiausiai tikètino sąlyčio su kelių danga juostoje. Automobilių kelių AB dangos atsparumas plyšiams apibūdinamas jos $\mathrm{AB}$ sluoksnių atsparumu tempimui lenkiant.

Spręsti apie automobilių ratų apkrovų poveiki kelių dangai ir KDK (jų naudojimo laikotarpiu) galima tik tada, kai žinomas ciklinių apkrovų, kurias dangos asfaltbetonio bandinys atlaiko iki suirties, skaičius $N$ ir šio skaičiaus sietis su bandinyje susidarančiu įtempių amplitude $\sigma$ arba su santykine bandinio deformacija $\varepsilon$ (ОДН 218.046-01, Li, Metcalf 2002; Li, Metcalf 2004, Pellinan et al. 2004).

Tyrimai (Puodžiukas 2000; Yu 2005) parode, kad kelių dangos lygumas labai priklauso nuo KDK pagrindo tipo, jo storio ir būklès. Jeigu AB dangos sluoksnių sankiba būna nepakankama, dangos funkcionavimo trukmé sumažèja $30 \%$ (Petkevičius, Sivilevičius 2000).

Centrineje ir pietineje Vakarų Europos dalyje charakteringos šios AB dangos pažaidos: vèžès, bangos, slinktys ir bitumo dèmès (nuo sunkiųju transporto priemonių apkrovų gali susidaryti $1,5-3,0 \mathrm{~cm}$ gylio vèžès) (Hongbing et al. 2004; Tarelder et al. 2005).

JAV automobiliu keliuose dominuoja $\mathrm{AB}$ dangos temperatūros įtakos ir nuovargio plyšiai, tik pietinèse valstijose vyrauja plastinio pobūdžio pažaidos (Tarelder et al. 2005).

Rusijoje atlikti tyrimai parode, kad jos 2-oje ir 3-ioje kelių ir klimato zonose automobilių kelių dangos $\mathrm{AB}$ sluoksniai dažniausia (75-80\% atvejų) suyra atsiradus plyšiams (Sivilevičius, Petkevičius 2002).

De Solminihac et al. (2003), Jongvon, Sandhyeok (2006), parodè, kad automobilių kelių dangos būklę ir funkcionavimo trukmę apibūdinantys svarbiausi rodikliai yra asfaltbetonio atsparumas tempimui lenkiant $R_{l}^{(a)}$, keliu dangos konstrukcijos sluoksnių tampros moduliai $E$ ir asfaltbetonio atsparumas nuovargiui $N^{(a)}$ (Petkevičius 2000; Petkevičius, Podagèlis 2000).

Darbų (Hudson, Flanagen 1987; Arand 1991; Puodžiukas 2000; Zhang et al. 2000; Sivilevičius, Petkevičius 2002; Petkevičius et al. 2010) analizè parodè, 
kad veikiančių kelių dangą veiksnių įtaka yra sudètinga, nes vieni veiksniai turi itakos kitiems veiksniams. STP ratų dinaminè apkrova išauga pablogejjus dangos lygumui ir padidejjus jų važiavimo greičiui, įtempiai kelių dangoje dažniausia padidejja, padidinus dangos šiurkštumą ir kt.

Puodžiukas (2000), Zhang et al. (2000), Barnes, Trottier (2010) Bausano et al. (2004) teigia, kad, kuo lygesnè keliu danga, tuo greičiau STP gali važiuoti, mažiau dyla jų ratų padangos ir mažiau suvartojama degalų, padideja STP tarpremontinis laikotarpis, padideja jų darbo našumas, būna mažesnès transporto išlaidos, saugesnis ir patogesnis eismas. Didejjant automobilių ratų apkrovai, kelių dangos funkcionavimo trukmè mažèja. Ji mažèja labiau (didesniu greičiu) nei didèja apkrova.

Tyrimais (Zhang et al. 2000; Romero et al. 2006).nustatyta, kad žemès sankasos grunte aktyvūs šlyties įtempiai $\tau_{i}$ beveik tiesiškai priklauso nuo kelių dangos apkrovų, o nuo oro slègio automobilių ratų padangose priklauso labai mažai.

Tyrimu (Hall, Turner 1998; Salama et al. 2006) rezultatai rodo, kad STP ratų padangose slègi padidinus du kartus, kelių dangos santykinis įlinkis padidejja $5,4 \%$.

Pagal Al-Quadi et al. (2002), Richter, Schwartz (2003).duomenis, kai asfaltbetonio sluoksnių storis $h=22 \mathrm{~cm}$ ir STP ratu padangose oro slègis padidinamas nuo $p_{0}=0,6 \mathrm{MPa}$ iki $p_{0}=0,7 \mathrm{MPa}$ (kai rato apkrova pastovi), KDK funkcionavimo iki kapitalinio remonto trukmè sumažèja $15 \%$, o jų ratų padangose padidinus oro slègi nuo $p_{0}=0,7 \mathrm{MPa}$ iki $p_{0}=0,9 \mathrm{MPa}$, jos funkcionavimo trukmè sumažeja 1,5 karto.

Kelių dangos būklè ir funkcionavimo trukmė priklauso nuo KDK stiprio. KDK būklei ir funkcionavimo trukmei didelę ịtaką turi ne tik važiuojančių transporto priemoniu poveikis, bet ir aplinkos veiksniai: klimato, hidrologiniai ir hidrogeologiniai. Didžiausią ịtaką žemès sankasos hidroterminiam režimui turi klimatas, lemiantis kritulių kiekị ir oro temperatūrą (Šiaudinis, Cygas 2007).

Didžiausią ịtaką kelių dangai turi teigiamų ir neigiamų temperatūrų kaita. Lietuvoje tokių kaitu per metus pasitaiko nuo 50 iki 80 (Juknevičiūtè, Laurinavičius 2008). Lietuvos teritorija yra plačiai besivystančių kriogeninių procesų zonoje - šie procesai susiję su sezoniniais ir ilgamečiais gruntų ǐšlimais ir atitirpimais, taip pat su požeminių ir paviršiaus vandenų užšalimu (RSN 25694).

KDK naudojimo laikotarpis (funkcionavimo trukmè) skirtingomis klimato sąlygomis (kai kitos sąlygos yra identiškos), gali skirtis iki trijų kartų (Ekdahl 1999).

Temperatūra daro didelę įtaką dangos būklei ir savybèms: veikia dangos asfaltbetonio savybes (didina arba mažina jo plastiškumą, trapumą ir kt.); veikia 
dangos asfaltbetonio įtempius, atsirandančius dèl temperatūros ir jos kitimo laike.

Sezoniniai pokyčiai lemia kritulių kiekio svyravimus ir veikia dangos konstrukcijos drèkinimo sąlygas. Laikoma, kad Lietuvoje kritiškiausias yra pavasario laikotarpis, kai iš žemès sankasos ir kelio konstrukcijos išeina ǐšalas (apie kovo mènesi), ir KDK sluoksniai yra daugiausia prisotinti vandens. Vanduo dangos konstrukcijoje, ypač sluoksniuose iš biriujų medžiagų, veikia jų standumą - tampros modulị, taip pat ir atsparumą apkrovoms (Braga 2005; Butkevičius 2007).

Lietuvos klimatui būdingas perejjimas iš jūrinio vakaruose i žemyninị rytuose. Klimato skirtumus lemia kontinentiniai ir okeaniniai (Atlanto vandenyno) itakos veiksniai. Vidutinè metinè oro temperatūra Lietuvos teritorijoje $+6{ }^{\circ} \mathrm{C}$. Vidutinè mènesio temperatūra ịvaireja nuo $-6{ }^{\circ} \mathrm{C}$ iki $+18{ }^{\circ} \mathrm{C}$. Vidutinè mènesių temperatūrų metinè amplitudè, tolstant nuo Baltijos jūros, Lietuvoje dideja nuo $18{ }^{\circ} \mathrm{C}$ iki $24^{\circ} \mathrm{C}$. Kritulių pasiskirstymui atskirais mènesiais turi ịtakos atstumas nuo jūros ir drègmę nešantys vejjai. Vasarą daugiau kritulių iškrinta Lietuvos rytuose, o žiemą-vakaruose. Vidutinis kritulių kiekis Lietuvoje - $620 \mathrm{~mm}$ (RSN 256-94).

Gruntų vidutinis išalo gylis Lietuvoje $-80-120 \mathrm{~cm}$, o pietineje Lietuvos dalyje - daugiau kaip $120 \mathrm{~cm}$ (Juknevičiūtè, Laurinavičius 2008). Žemiausia temperatūra Lietuvoje ịvaireja nuo $-22{ }^{\circ} \mathrm{C}$ iki $-35^{\circ} \mathrm{C}$, o aukščiausia - nuo $+25^{\circ} \mathrm{C}$ iki $+32{ }^{\circ} \mathrm{C}$. Vasarą, esant aukščiausiai oro temperatūrai iki $+30^{\circ} \mathrm{C}$, asfaltinè danga îšla iki $+45^{\circ} \mathrm{C}$, o kai oro temperatūra būna didesnè nei $+30^{\circ} \mathrm{C}$, danga gali išsilti iki $+50{ }^{\circ} \mathrm{C}$ ir daugiau.

Taigi pagal HDM taikomą suskirstymą, Lietuvą galima priskirti vidutinio arba vidutinio - šalto pusiau sauso klimato juostai (Braga 2005).

KDK veikiantys veiksniai egzistuoja laike (jų poveikis pasireiškia $A B$ dangos ir KDK būklès vizualiai pastebimu blogèjimu tik praejjus nemažam, dažniausia ne mažesniam kaip vieneri metai, laikotarpiui). Eksploatuojant $A B$ dangą ir KDK, keičiasi asfaltbetonio savybès ir mažèja jo geba priešintis transporto priemonių apkrovų, klimato veiksnių bei žiemos sąlygomis naudojamų cheminių reagentų poveikiui.

Taip pat, siekiant optimizuoti kelio statybos kainą ir pasiekti galimai geriausią rezultatą, panaudojus šalyje turimus gamtinius išteklius, îvertinant specifines aplinkos, klimato sąlygas, naudojamų medžiagų savybes ir transporto priemonių eismo intensyvumą, šiuo metu pasaulyje plačiai taikomas mechaninis daugiakriterinis KDK skaičiavimo modelis - MEPDG, tačiau įvertinti visus KDK irti ịtakojančius veiksnius ir atlikti tikslią jų prognozę dar niekam nėra pavykę (Ioannides, Tallapragada 2013; Tarefder, Rodriguez-Ruiz 2013; Thodesen et al. 2012; Žilionienè et al. 2013; Wu et al. 2013). 
Pastaraisiais metais užsienio šalių mokslininkai (Noureldin 1997; Kim et al. 2003, 2004, 2009 Yavuzturk et al. 2005; Lackner et al. 2005; Gui et al. 2007; Seo et al. 2007; Bhasin et al. 2009) kūrè asfaltbetonio struktūros ir savybių pagerinimo naujus metodus, taikydami naujausius mokslo pasiekimus ir naudodami modernią tyrimų ịrangą, tačiau šie mokslo darbai skirti $A B$ savybėms pagerinti laboratorijų sąlygomis. Šių savybių (su turima technologine iranga) pasiekti, realiai gaminant asfaltinius mišinius ir įrengiant $\mathrm{AB}$ dangą, neịmanoma. Kai kuriuose darbuose (Lundstrom et al. 2004; Kim et al. 2005; Pellinen et al. 2004; Choi, Bahia 2004; Tighe et al. 2007; Lee et al. 2007; Ahammed, Tighe 2008; Li et al. 2008) taip pat nagrinejamos AB dangos ir KDK funkcionavimo sąlygos ir šių sąlygų itaka $\mathrm{AB}$ dangos ir KDK funkcionavimo trukmei. Visi šie darbai yra reikšmingi mokslo vystymo požiūriu, tačiau didžiojoje jų dalyje pasigendama rekomendacijų, kad gauti svarbiausieji rezultatai būtų panaudoti praktikoje. Laboratorinemis sąlygomis ištirtos $A B$ savybès parodo šios medžiagos galimybes priešintis transporto priemonių ir aplinkos veiksnių poveikiui. Faktinès AB dangos ir KDK funkcionavimo sąlygos gerokai skiriasi nuo laboratorijoje sukurtų sąlygų, todèl asfaltbetonị reikia tirti irengtoje dangoje. Geriausia ji tirti eksperimentiniuose ruožuose, pavyzdžiui, tokiuose, kaip įrengtas Lietuvoje (Čygas et al. 2008).

Asfaltbetonis - tai medžiaga su grižtamaisiais mikrostruktūros, atspindinčios kiekybini bitumo santykị, išdèstymą ir tarpusavio poveiki dispersiškiausiam (smulkiausiam) ir aktyviausiam asfaltbetonio komponentui mineraliniams milteliams, pokyčiais, galinti būti šių struktūros būvių: tampriai trapaus, tampriai plastinio ir klampiai plastinio (Рыбъев 2008).

Atliktų darbų analizè parodé, kad AB danga ir KDK funkcionuoja labai sudėtingomis, nuolat kintančiomis aplinkos sąlygomis ir veikiant dažnai pasikartojančioms transporto priemonių apkrovoms. Šų apkrovų pobūdis (poveikio trukmè, dydis, pasikartojimo dažnis) nuolat kinta.

Kai kurios kelių dangos pažaidos atsiranda ir vystosi dèl sluoksnių medžiagų ir nepakankamos kelių tiesybos darbų kokybès. Nepakankama šių darbų kokybè pasireiškia mažesniu KDK vienodumu ir didesne jos savybių sklaida. Lietuvoje, priklausomai nuo kelio reikšmès, taikomi skirtingi reikalavimai KDK kokybei (KDK sluoksnių medžiagu sutankinimo rodikliui, sluoksnių storių sklaidai, bitumo ir mineralinių medžiagų komponentų santykinès dalies asfaltbetonyje nuokrypiams (\%) nuo AB projektinès sudèties, dangos lygumui (ją i̧rengus) ir kt. (KTR 1.01:2008; TRA ASFALTAS 08)), kurie lemia magistralinių, krašto ir rajoninių kelių skirtingas eksploatacines savybes jau iš karto, irengus asfaltbetoninę dangą, taip pat lemia skirtingą šių savybių kitejimą, eksploatuojant $\mathrm{AB}$ dangą ir KDK.

Amerikos (JAV) kelių ir transporto pareigūnų asociacijos AASHTO atliktų tyrimų rezultatai parode, kad $15 \%$,geriausios“ kelių dangos ruožų gali 
funkcionuoti 6-10 kartų ilgiau nei $15 \%$ „blogiausios“ dangos ruožų, esančių pagal tą pati projektą nutiestame tame pačiame kelyje. Imant kelių dangos funkcionavimo vidutini laikotarpi $T=10$ metų, „blogiausi““ jos ruožai funkcionuotu apie 3-4 metus, o „geriausi“ - apie 25-30 metų. Taigi netgi tokia pati KDK, tie patys standartai, technologijos, transporto priemonių eismas ir aplinkos sąlygos negali užtikrinti identiškos kelių dangos irties (Ekdahl 2000).

Kelių dangos irtis - natūralus procesas, priklausantis nuo ịvairių veiksnių, kurių dauguma - atsitiktiniai veiksniai, todèl jie negali būti tiksliai išmatuoti ir ivertinti. Visus kelių dangos irčiai itakos turinčius veiksnius ištirti ir sumodeliuoti iki šiol dar niekam nèra pavykę (Ekdahl 1999).

\subsection{Keliụ tampriosios dangos konstrukcijụ defektai ir jų susidarymo priežastys}

Dažniausiai pasitaikančios dangos pažaidos ir suirtis: nuodyla - pagrindinis dangos suirties tipas; išaižos - pažaidos, susidarančios mineraliniams dangos paviršiaus grūdeliams atsilupus nuo monolitinès asfaltbetoninès dangos: medžiagos paviršiaus (plonos plèvelès, plokštelès ir smulkūs grūdeliai atsiskiria dèl vandens, šalčio ir automobilių ratų poveikio, susidarant iki $5 \mathrm{~mm}$ gylio mikronelygumams); ištrupos - po išaižų einanti dangos suirties pažaidų fazè (nuo dangos atsiskiria stambesni mineraliniai grūdeliai ir susidaro nuo kelių iki $20 \mathrm{~mm}$ gylio nedidelio ploto ištrupos); kraštu ịlūžiai - dangos suirtis jos sąlyčio su kelkraščiu vietose; išdaužos (duobès) - nuo 20 iki $100 \mathrm{~mm}$, o kartais - ir didesnio gylio vietinè suirtis, susidaranti dèl mineralinių medžiagų grūdelių ir bitumo ar nepakankamos kitų organinių rišiklių sankibos, dèl nepakankamo dangos tankio ir kitŭ priežasčių; vèžès - šlyties liekamosios deformacijos, atsirandančios dèl daugiaašių STP poveikio asfaltinei dangai; bangos liekamosios deformacijos, susidarančios didelio plastiškumo dangoje; slinktys dangos liekamosios deformacijos, susidarančios dèl važiuojančiu automobilių ratų tangentinių jègų, atsirandančių stabdant automobilius, poveikio; ispaudos plastiški dangos pagilejjimai, atsirandantys šiltuoju laikotarpiu, dažniausiai vasarą; plyšiai - kelių $\mathrm{AB}$ dangos pagrindinis suirties tipas (Sivilevičius, Petkevičius 2002 ).

$\mathrm{AB}$ dangos ir KDK irtị ir pažaidų joje atsiradimą lemiantys veiksniai yra šie: nenumatytos labai didelès masès STP važiavimas keliu, pernelyg didelis STP eismo intensyvumas, automobilių apkrovu ir eismo intensyvumo augimo nepakankamas ivvertinimas projektuojant, nepakankamas aplinkos veiksniu ivertinimas, neteisingas KDK apskaičiavimas, prastos kokybès kelių tiesybos medžiagų dangos konstrukcijoje naudojimas ir kt. (Butkevičius 2007). 
Pagrindiniai kelių AB dangos ir KDK suirties ir pažaidų tipai yra šie: išilginiai nuovargio plyšiai arba plyšių tinklas, atsirandantys dangai ir jos konstrukcijai prarandant stipri; nestandžios dangos konstrukcijos nuosèdžiai. Kelių dangos ir KDK pažaidụ gausèjimas labiausiai priklauso nuo medžiagų, iš kurių jos įrengtos, stiprio (Sivilevičius, Petkevičius 2002; Petkevičius 2008).

Pirmieji plyšiai dangoje ir jos ištrupos (paviršiaus erozija) bei išdaužos dažniausiai atsiranda po kelerių metų, ją paklojus. Vèliau šių dangos pažaidų formavimasis suintensyvejja: plyšiai platėja ir gilèja, erozijos pažeistų dangos vietų plotas ir išdaužų tūris didèja, todèl laiku nepašalintos pažaidos pasiekia kritines vertes, ir kelias tampa sunkiai pravažiuojamas bei neatlieka savo tiesioginès paskirties. Automobilių kelių AB dangos suirties mastą, išreikštą \%, siūloma įvertinti rodikliu $D_{D}$ (Sivilevičius, Petkevičius 2002):

$$
D_{D}=\left(S_{d}+S_{p l}+S_{p}+S_{p d}+S_{n d}+\sum_{i=1}^{n} l_{i} b_{i}\right) \cdot 100 / S_{A B},
$$

čia $S_{d}$ - tiriamajame ruože pažeistos išaižomis, ištrupomis, kraštų (briaunų) ištrupomis, išdaužomis, igriuvomis ir užtaisytos lopais dangos plotas, $\mathrm{m}^{2} ; S_{p l}-$ dangos, pažeistos plyšių tinklu, plotas, $\mathrm{m}^{2} ; S_{p}-$ dangos, pažeistos liekamosiomis plastinèmis deformacijomis: vèžèmis, bangomis, slinktimis, idubomis, plotas, $\mathrm{m}^{2} ; S_{p d}$ - dangos, pažeistos paviršiaus defektais: bitumo dèmèmis, ištirpusio bitumo vietomis, plotas, $\mathrm{m}^{2} ; S_{n d}-$ dangos, pažeistos paviršiaus nuodyla ir sumažejusio šiurkštumo vietomis, plotas, $\mathrm{m}^{2} ; l_{i}$-atskiro $i$-tojo plyšio ilgis, $\mathrm{m} ; b_{i}$ - dangos juostos, praradusios stipri, plotis iš abiejų $i$ tojo plyšio pusių, priklausantis nuo plyšio pločio, $\mathrm{m} ; S_{A B}$ - tiriamo kelio ruožo visos $\mathrm{AB}$ dangos plotas, $\mathrm{m}^{2}$.

Eksploatacinès tik ką nutiesto kelio savybès būna geriausios, o važiuojant keliu jo geometriniai parametrai kinta nedaug. Kelio AB danga, tiesiogiai veikiama automobilių ratų bei klimato veiksnių, nuolat keičia savo savybes. Dèl to mažejja dangos ir KDK stipris. Veikiant automobilių ratu kartotinèms vertikaliosioms ir horizontaliosioms apkrovoms, $\mathrm{AB}$ dangoje susidaro nuovargio plyšių. Susidarę plyšiai, vėžès ir kiti defektai intensyviai vystosi, dèl to blogejja dangos lygumas, o automobilių ratų apkrovos tampa dinaminès, sukeliančios didelius smūgius ir intensyvinančios dangos silpniausių ruožų irti. Visi šie defektai yra sezoninio pobūdžio: kiekvieną pavasarị, polaidžio metu, smarkiai sumažeja KDK stipris, praplatejja temperatūros (skersiniai) ir kiti plyšiai, labiau aižèja AB dangos paviršius (Zhang et al. 2000; Sivilevičius 2003).

Kadangi medžiagu savybès ir asfaltinio mišinio gamybos, klojimo ir tankinimo technologiniu operaciju parametrai nepaliaujamai kinta ir yra atsitiktinio pobūdžio, paklota $\mathrm{AB}$ danga savo savybèmis nebūna visur vienoda. 
$\mathrm{AB}$ mineralinès dalies granuliometrinè sudètis, jo tuštymètumo ir sutankinimo (dangoje) rodiklis bei kiti fiziniai rodikliai, bitumo kiekis ir asfaltinio mišinio gamybai naudojamų medžiagų savybès, AB dangos sluoksnių storis dangos plote kinta gana plačiai, todèl dangos mechaninès savybès taip pat būna nevienodos. Vienuose elementariuose dangos plotuose asfaltbetonis būna gerokai silpnesnis nei greta esančiuose kituose, kuriuose jo faktinis stipris labai viršija reikiamą jo stiprị. Dél skirtingo $\mathrm{AB}$ dangos vienodumo asfaltbetonis visame dangos plote iškart nesuyra. Kuo mažesnis dangos vienodumas, tuo anksčiau atskiri jos plotai gali pradèti irti ir tuo anksčiau gali prireikti ją remontuoti. Nevienodi yra ir klimato veiksniai bei jų poveikis dangai (Petkevičius, Sivilevičius 2000; Sivilevičius 2003).

Mechaniškai apkrovus kelių dangos asfaltbetoni, atsiskleidžia jam būdingos šios sudètingos savybès: tamprumas, plastiškumas, slankumas, įtempių relaksacija, kintant deformavimo greičiui, stipris, deformacijų kaupimasis, esant daugkartinei labai dažnai apkrovai ir kt. Asfaltbetoninejje dangoje, veikiamoje susisiekimo priemonių apkrovoms, atsiranda įtempių. Danga suplyšta, kai tempimo ịtempiai pasiekia ir viršija dangos stiprị tempiant. Kelių dangos itempiai būna tokie (ОДН 218.046-01; Petkevičius, Sivilevičius 2002):

- temperatūros pobūdžio tempimo ịtempiai $\sigma_{t}$, atsirandantys dèl to, kad atšąlant susitraukianti danga negali laisvai pasislinkti;

- ịtempiai $\sigma_{p}$, atsirandantys dangoje dèl netolygiai pakilusio po danga esančio žemės sankasos peršalusio grunto neigiamoje aplinkos ir grunto temperatūroje;

- tempimo ir šlyties įtempiai $\sigma_{\breve{s} l}$, atsirandantys lètejjant ar greitejjant automobiliams;

- periodiniai tempimo ittempiai $\sigma_{l}$, atsirandantys automobilių ratams vertikaliai slegiant dangą.

Senstančios dangos elastingumas mažèja, o tempimo įtempiai nuolat didejja, plyšių kiekis ir plotis taip pat didejja.

Kelių AB dangos būklè gali būti ịvertinta dviem būdais:

- naudojant tam tikrus apibendrinamuosius būklès rodiklius: Lietuvoje ir kai kuriose kitose pasaulio šalyse naudojamas asfaltbetoninès dangos būklès apibendrinamasis rodiklis - jos suirties mastas $D_{D}$ (angl. pavement distress index) (Sivilevičius, Petkevičius 2002; Paterson, Bennet 2001; Haas et al. 2006), JAV, Kanadoje, Australijoje ir kitur naudojami šie rodikliai: dangos kokybès indeksas PSI (angl. pavement serviceability index (AASHTO Quide... 1993), važiavimo kokybès indeksas RCI (angl. ride comfort index), defektų indeksas DMI (angl. distress manifestation index) (Kazmierowski, Ninguan 2002) ir kiti; 
- vertinant keletą kriterijų - kelių dangos eksploatacinių savybių, atskirai; dangos eksploatacinès savybès apibūdinamos dangos pažaidų skaičiumi ir jų išsivystymo laipsniu, taip pat dangos lygumu ir automobilių ratų sankiba su danga; šis AB dangos būklès vertinimo būdas taikomas HDM dangu irties modeliuose, jis reglamentuotas ir Lietuvoje (Automobiliu kelių... 2004).

Kai dangos būklè vertinama antruoju būdu, visą dangos irties modeli sudaro keletas mažesnių modelių. Juos taikant prognozuojamos įvairios dangos pažaidos ir jų plètra bei poveikis kitoms dangos pažaidoms ir jų eksploatacinėms savybėms.

Vakarų Europos šalyse, JAV ir kitose poindustrinèse valstybèse keliu dangos būklei valdyti sukurtos specialios sistemos. Žinomiausios yra HDM (Pasaulio bankas), Belman (Danija), Quantum (JAV) ir kt. (Puodžiukas 2000; Li et al. 2005; Schmuck, Hekenberger 1993). Šios sistemos sukurtos panaudojus automobilių kelių dangos būklès ilgalaikių tyrimų duomenis. Daugelyje Vakarų Europos šalių kelių dangos būklei valdyti naudojamas HDM-IV modelis.

Dauguma pažaidų daro poveiki kelių dangos lygumo blogejjimui. HDM modeliuose dangos lygumas - tai jos savybè, kuri nusako kiekvieno kelio poveiki automobiliams. Lietuvoje taikomoje sistemoje DAVASEMA (kaip ir HDM sistemoje) dangos lygumas vertinamas tarptautiniu lygumo rodikliu IRI (angl. International Roughness Index). W. Patersonas pateikia toki IRI apibrezžimą (Paterson 1987): tai suma automobilio vibracijų, kurias sukelia kelio išilginio profilio nelygumai véžèse (provèžose) - standartinio automobilio, važiuojančio $80 \mathrm{~km} / \mathrm{h}$ greičiu, pakabos vertikaliujų poslinkių sumos ir nuvažiuoto kelio santykis.

Automobilių kelių tyrimo mobiliojoje laboratorijoje RST-28, skirtoje geometriniams kelių parametrams ir dangos defektams matuoti, sumontuota sudètinga įranga leidžia saugiai atlikti matavimus, laboratorijai važiuojant transporto priemonių sraute $20-90 \mathrm{~km} / \mathrm{h}$ greičiu. Idiegtos naujos technologijos užtikrina didelį matavimo duomenų tikslumą ir nustatytus dangos parametrus bei defektus leidžia pateikti LKS 94 koordinačių sistemoje (Dimaitis 2008). Nustatomos šios dangos charakteristikos:

- dangos lygumas išilgine kryptimi $Y_{\text {IRI }}, \mathrm{m} / \mathrm{km}$;

- dangos šiurkštumas (vidutinis makroprofilio gylis), mm;

- vėžiu gylio $(\mathrm{mm})$ matavimai atliekami kas $10 \mathrm{~cm}$, o apskaičiuojami kiekvieno 20 m ilgio kelio ruožo kiekvienos vèžès vidutiniai gyliai;

- dangos plyšiai ir kiti defektai nustatomi vaizdo kameromis ir siunčiami i kompiuteri, o duomenys apdorojami pagal specialią programą, t. y. filtruojami, uždedant ant tinklelio, kurio langelių matmenys $0,5 \times 0,5 \mathrm{~m}$ (jie gali būti ir mažesni); matavimai atliekami per visą važiavimo juostos 
plotą, o defektai pateikiami grafiniuose lapuose ir elektroninèse lentelèse. Pagal šiuos duomenis nustatomas defektais pažeistos (suirusios) dangos plotas, \%.

- Panaudojus laboratoriją RST-28, $2007 \mathrm{~m}$. buvo ištirti (Dimaitis 2008) visi magistraliniai keliai, kurių ilgis - $1750,5 \mathrm{~km}$ ir apie $3000 \mathrm{~km}$ krašto kelių. Tyrimai parodè, kad magistralinių kelių tinkle yra labai daug blogos (nelygios) dangos ruožų, kurios SDSL siekia $30 \%$ ir daugiau. Šiuose ruožuose $A B$ dangą reikètų suremontuoti kapitališkai (ją sustiprinti, įrengiant naują $\mathrm{AB}$ dangos sluoksnį). Šių ruožų remonto kaina tris kartus viršijo 2008 metams numatytas dangos remontams lèšas (Dimaitis 2008).

Siekiant sumažinti automobilių kelių ruožų dalị, išreiškiamą \%, su labai suirusia ir nelygia $\mathrm{AB}$ danga, pravartu ieškoti efektyvių būdų ir priemonių (nedidinant išlaidų remontams) dangos lygumui pagerinti. Viena galimų priemonių - $\mathrm{AB}$ dangos ir dangos asfaltbetonio kokybès charakteristikų reikiamų verčių nustatymas:

- $\mathrm{AB}$ dangos sluoksnių reikiamo storio $h$ ir sutankinimo laipsnio (pagal sutankinimo koeficientą $k_{s}$ );

- $\mathrm{AB}$ dangos leidžiamojo suirties masto $D_{D}$ ir leidžiamojo lygumo (iki remonto) pagal tarptautinį indeksą $I R I Y_{I R I}$;

- AB dangos leistinojo véžètumo $H_{V}$;

- įrengiamos dangos asfaltbetonio fizinių ir mechaninių rodiklių pagal Maršalą verčių, užtikrinančių kuo ilgesnį dangos tarpremontinị laikotarpi (funkcionavimo trukmę).

Siekiant pagerinti $\mathrm{AB}$ dangos ir KDK būklę, su analogiškomis problemomis susiduriama tiek poindustrinèse Europos ir kitų žemynų šalyse (JAV, Kanadoje, Japonijoje, Vokietijoje, Prancūzijoje, Šveicarijoje, Danijoje, Austrijoje, Italijoje, Belgijoje, Olandijoje, Australijoje ir kt.), tiek mažiau išsivysčiusiose Vidurio ir Rytų Europos bei kitų žemynų šalyse (Lenkijoje, Čekijoje, Vengrijoje, Rusijoje, Baltarusijoje, Ukrainoje, Kinijoje, Indijoje, Brazilijoje, Pietų Afrikos Respublikoje (PAR)) (Braga 2005; Butkevičius 2007). Šios šalys yra sukūrusios jų sąlygoms (klimatui, automobilių kelių tinklui ir kelių $\mathrm{AB}$ dangos būklei) tinkamas $\mathrm{AB}$ dangos ir KDK būklès vertinimo metodikas.

Lietuvoje turint laboratoriją RST-28, keliụ dangos ir KDK būklès prognozè pagal mūsų šalies sąlygoms priderintą HDM-IV metodiką (Braga 2005) ateityje, matyt, bus taikoma labiau apribotai.

Rusijoje (Коганзон, Лугов 2004; Бахрах 2008; Апестин 2007), Ukrainoje (Радовский, Сердюк 1997), Baltarusijoje (Яромко 2008), Lietuvoje (Butkevičius 2007) ir kitose šalyse atliktuose tyrimuose siūloma ịvertinti KDK stiprio likutinị resursą ir ekonominius rodiklius. Visi šie siūlymai, išskyrus 
Jaromko darbą (Яромко 2008), yra sudètingi ir sunkiai pritaikomi praktikoje, nes reikia turèti daug tyrimų rezultatų ir atlikti sudètingus rodiklių skaičiavimus.

Atliktų darbų analizè parodè, kad iki šiol dar niekas nepasiūlè universalaus ir patogaus rodiklio kelių ar kelių dangos būklei vertinti. Patogiausias rodiklis kelių dangos būklei vertinti - VGTU Keliu katedros pasiūlytas kelių dangos suirties mastas $D_{D}$ (Sivilevičius, Petkevičius 2002).

\subsection{Pirmojo skyriaus išvados ir darbo uždavinių formulavimas}

1. Lietuvos automobilių kelių asfaltbetoninès dangos priežiūros ir taisymo didžiausios problemos susijusios su daugiaašių sunkiujų transporto priemonių daugejjimu. Lietuvos keliai pagal dangos lygumą, kelių dangos konstrukcinjų stipri ir kitus rodiklius nèra pritaikyti didelių gabaritu sunkiosioms transporto priemonèms. Bendrajame transporto priemonių sraute daugejant sunkiųjų transporto priemonių, didejja svarbiausių automobilių kelių asfaltinės dangos ir kelių dangos konstrukcijos ardymo poveikis bei dangos irties intensyvumas.

3. Kelių dangos irtis - natūralus procesas, priklausantis nuo daugelio veiksnių, kurių dauguma atsitiktiniai veiksniai, todèl jie negali būti labai tiksliai išmatuoti ir ìvertinti. Visus kelių dangos irčiai turinčius įtakos veiksnius ištirti ir sumodeliuoti niekam nèra pavykę.

4. Daugelio autorių atlikti tyrimai parodè, kad kelių dangos būklè turi būti tikrinama nuolat (pavasarị ir rudenį), kad būtų galima objektyviau ir tiksliau nustatyti kelių asfaltinès dangos ir keliodangos konstrukcijos remonto darbų kasmetines apimtis. Dèl kintančių eismo sąlygų Lietuvos automobilių kelių dangos ir jos konstrukcijos eksploatacinių rodiklių blogejjimo intensyvumas laikui bėgant taip pat turi kitimo pobūdị.

5. Automobilių kelių asfaltinès dangos eksploataciniai rodikliai priklauso nuo jai ịrengti naudojamų medžiagų kokybès. Iki šiol pasaulyje nesukurta universali asfaltinès dangos bei kelių dangos konstrukcijų skaičiavimo metodika, ivvertinanti jos sluoksnių medžiagu kokybès rodiklius ir nesukurta asfaltinès dangos eksploatacinių rodiklių prognozès metodika, kurią taikant būtų galima tiksliai numatyti jos būklę ateityje.

6. Kitų šalių mokslininkų atliktuose tyrimuose įrodyta, kad, prognozuojant asfaltinès dangos ir kelių dangos konstrukcijos būklę, svarbiausiais eksploataciniais rodikliais turi būti pripažįstami šie: kelių dangos lygumas, vèžètumas ir suirties mastas, todèl tikslinga juos naudoti prognozuojant asfaltinès dangos ir kelių dangos konstrukcijos realią funkcionavimo trukmę.

7. Daug tyrèjų teigia, kad kelių asfaltinès dangos lygumas labai priklauso nuo kelių dangos konstrukciniu sluoksnių storio, dangos asfaltbetonio 
komponentinès sudèties ir fizinių bei mechaninių rodiklių. Visgi ši teiginị patvirtinančių tyrimų iki šiol atlikta nedaug. Darbo tikslas - parengti magistralinių automobilių kelių asfaltbetoninès dangos eksploatacinių rodiklių prognozès matematinius modelius, atsižvelgiant i tampriosios dangos konstrukcijų savybes ir transport priemonių eismo intensyvumą. Parengti modeliai, juos naudojant, leistų numatyti kelių asfaltbetoninės dangos lygumo ir vèžètumo rodiklių laukiamas vertes, praejus penkeriems jos naudojimo metams. Ši penkerių metų dangos funkcionavimo trukmè atitinka garantini dangos eksploatavimo laikotarpi, todèl parengtus modelius tikslinga naudoti patenkant racionalias magistralinių kelių tampriosios dangos konstrukcijas.

Darbo tikslui pasiekti reikia išspręsti šiuos uždavinius:

- išanalizuoti automobilių kelių asfaltbetoninès dangos eksploatacinius rodiklius lemiančius svarbiausius veiksnius ir šių rodiklių blogejjimo priežastis;

- atlikti magistralinių kelių dangos konstrukcijų sluoksniams naudojamų medžiagų ir mišinių kokybès rodiklių tyrimus;

- nustatyti dangos asfaltbetonio komponentinès sudèties, fiziniu bei mechaninių rodiklių ir asfaltiniams mišiniams naudojamų medžiagu kokybès rodiklių sietį;

- ištirti asfaltbetoninès dangos lygumo ir provèžų gylio kitejjimo dèsningumus;

- nustatyti dangos asfaltbetonio, kitų kelių dangos konstrukcinių sluoksnių medžiagu kokybès rodiklių ir asfaltbetoninès dangos lygumo bei provèžų gylio sietį;

- parinkti dvi racionalias magistralinių kelių tampriosios dangos konstrukcijas (skirtingam transporto priemonių eismui), ivvertinus jos sluoksniams naudojamų medžiagų kokybès rodiklius. 



\section{2}

\section{Automobilių kelių tampriosios dangos konstrukcijų projektavimo svarbiausieji principai}

Skyriuje apibūdintos asfaltbetoninès dangos ir jos konstrukcinių sluoksnių funkcionavimo sąlygos ir jų savybes veikiantys veiksniai. Pateikti kelio dangos funkcionavimo ir jos eksploatacinių rodikliu kitejjimo grafiniai modeliai. Nurodytas tampriosios kelių dangos racionalių konstrukcijų parinkimo metodas.

Skyriaus tematika paskelbti keturi autoriaus straipsniai (Bulevičius et al. 2010a; Bulevičius et al. 2011a, 2011b; Bulevičius et al. 2013).

\subsection{Asfaltbetoninès dangos ir kitų konstrukcinių sluoksnių funkcionavimo sąlygos}

$\mathrm{AB}$ danga ir KDK funkcionuoja konkrečiomis (vietinėmis) sąlygomis, kurios priklauso nuo šių veiksnių: dangos bei KDK sluoksnių medžiagų ir žemès sankasos (ŽS) gruntų savybių, šių sluoksnių storio ir jų sutankinimo lygio, klimato veiksnių, transporto priemonių apkrovų bei nuo vietos sąlygų (gruntinio vandens lygio (GVL), vietovès drèkinimo sąlygų), $\mathrm{AB}$ dangos ir KDK savybių (dangos eksploatacinių rodiklių: lygumo $Y_{\mathrm{IRI}}$ vèžètumo $H_{\mathrm{V}}$ ir suirties masto, 
KDK stiprio ir kt.). 2.1 paveiksle parodytas mūsų AB dangos bei KDK funkcionavimo sąlygoms ir jų savybėms bei būklei ịtakos turinčių veiksnių sieties modelis, patobulintas remiantis anksčiau sukurtais (Sivilevičius 2003; Petkevičius 2008, 2010) modeliais.

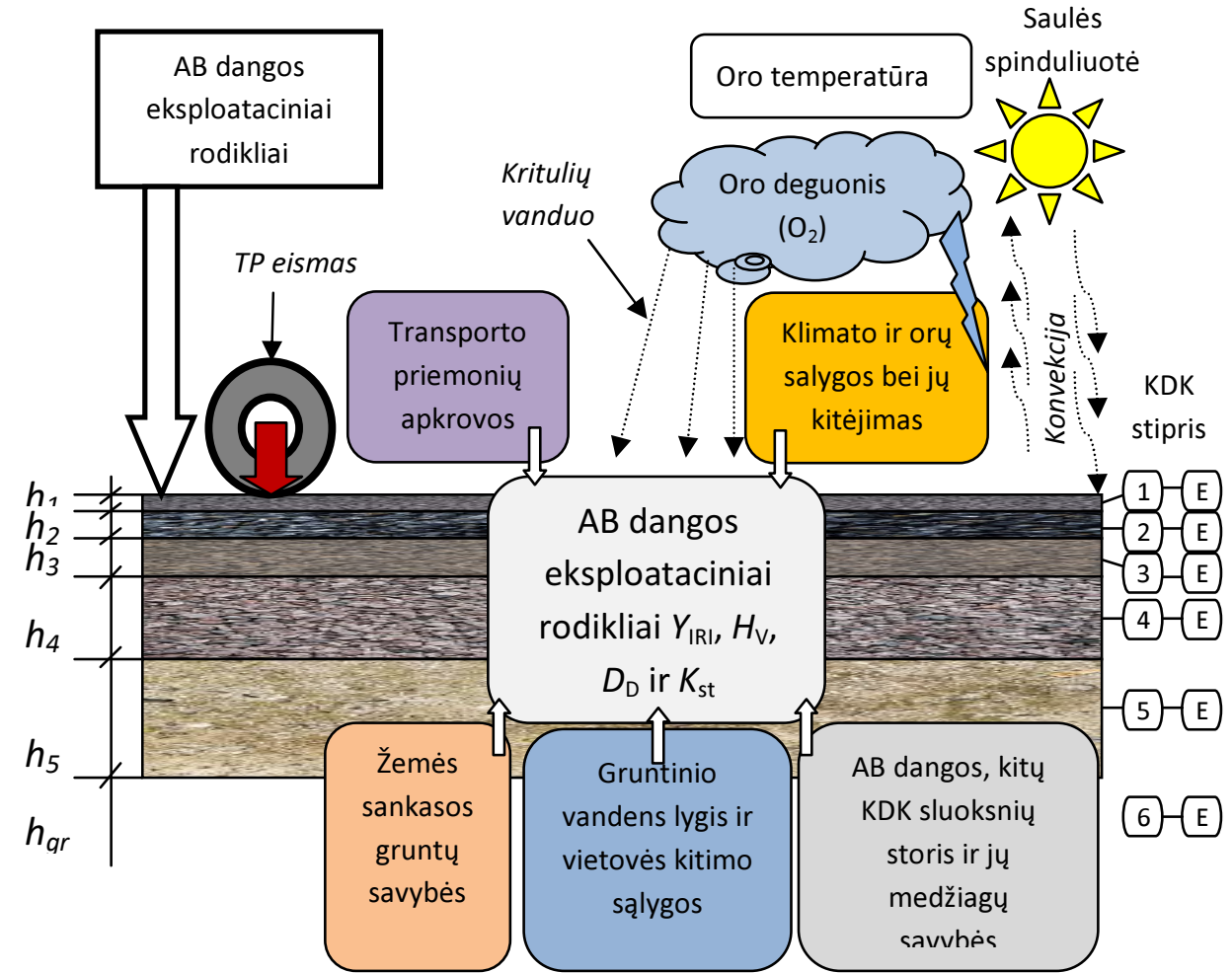

2.1 pav. $A B$ dangos lygumui, věžètumui, suirties mastui ir KDK stipriui įtakos turinčių veiksnių sieties modelis: $1-5-\mathrm{KDK}$ sluoksniai $(1-\mathrm{AB}$ dangos viršutinis ir $2-\mathrm{AB}$ dangos apatinis sluoksniai; 3 - AB pagrindo sluoksnis; 4 - skaldos (SK) arba žvyro (ŽV) pagrindo sluoksnis; 5 - smèlio (SM) ar kitos medžiagos apsauginis šalčiui atsparus sluoksnis); 6 - žemès sankasos (ŽS) gruntas; $E_{1}-E_{5}$ ir $h_{1}-h_{5}$ - atitinkamai KDK nurodytų sluoksnių tampros moduliai ir sluoksnių storiai; $E_{g r}$ ir $h_{g r}-$ atitinkamai ŽS grunto tampros modulis ir gunto aktyviosios zonos ekvivalentinis storis

Fig. 2.1. The model of interaction between the factors influencing the asphalt concrete pavement roughness, rutting, degradation extent, structural strength and condition: 1-5pavement structural layers $(1$ - asphalt concrete wearing course, and 2 - asphalt concrete base courses; 3 - asphalt concrete road base; 4 - crushed stone or gravel sub-base; 5 frost-blanket course from sand or other material); 6 - subgrade soil; $E_{1}-E_{5}$ and $h_{1}-h_{5}-$ moduli of elasticity and thicknesses of pavement structural layers, respectively; $E_{\mathrm{gr}}$ and $h_{\mathrm{gr}}-$ modulus of elasticity and equivalent thickness of the active zone of subgrade soil, respectively 
Šis modelis ịvertina svarbiausius AB dangos lygumui, KDK stipriui ir jų būklei didelị poveikį darančius veiksnius. Paveiksle visų rodikliu $\left(E_{1}-E_{5}, h_{1}-h_{5}\right.$ ir $\left.E_{\mathrm{gr}}\right)$ vertės, išskyrus rodiklį $h_{\mathrm{gr}}$, nustatomos iš norminių dokumentų, parinkus KDK medžiagas ir žinant vietovès gruntą. Rodiklio $h_{\mathrm{gr}}$ vertè nustatoma iš žinomos priklausomybès.

2.1 paveiksle pateikti veiksniai nèra pastovūs (determinuoti). Jų veikimo pobūdis yra atsitiktinis, todèl jų poveikio vertès kitejja atsitiktinai (stochastiškai), neviršydamos tam tikrų ribų. Vieni šių veiksnių yra periodinio pobūdžio: jų vertės periodiškai kartojasi per parą (ryte, dieną, vakare ir nakti), taip pat metu sezonais (pavasarị, vasarą, rudenị ir žiemą). Šie veiksniai - tai oro temperatūra ir saulès spinduliuoté, sudaranti metų saulès spinduliuotès balansą. Kiti veiksniai kitejja (tam tikrose ribose) visiškai atsitiktinai (daugumos jų vertès kitejja pagal normalujji dèsnį): vèjas (jo greitis); kritulių kiekis; transporto priemonių apkrovos; $\mathrm{AB}$ dangos ir kitu KDK sluoksnių kokybès rodikliai (storis ir sutankinimo koeficientas); kelio dangos asfaltbetonio sudetis, fiziniai ir mechaniniai bei kiti kokybès rodikliai; KDK nerišliujų sluoksnių medžiagų granuliometrinè sudètis ir kiti kokybès rodikliai; žemès sankasos gruntų granuliometrinè sudètis, drègnis ir kiti kokybès bei stiprumo rodikliai (Barnes, Trotlier 2010; François, Jullien 2009). Dalis veiksnių pastovūs (nekiteja arba kitejja labai mažai): deguonies kiekis (procentinè dalis) ore, gruntinio vandens lygis. Vienas svarbus veiksnys, veikiantis šaltuoju laikotarpiu - gruntų ǐšalo gylis, kiteja priklausomai nuo atstumo iki jūros (Lietuvos valstybès atveju Baltijos jūros), sniego dangos storio, taip pat šaltojo sezono (žiemos) vidutinès neigiamosios ir žemiausios neigiamosios temperatūros ir kitų veiksnių (Sivilevičius 2003; Juknevičiūtè, Žilinskienė 2009; Petkevičius 2008).

Daugelis aptartu veiksnių AB dangos eksploataciniams rodikliams (lygumui $Y_{\text {IRI }}$, véžètumui $H_{\mathrm{v}}$ ), KDK stipriui ir jų būklei turi sudetingą poveikị. Labai dažnai $\mathrm{AB}$ dangą ir KDK vienu metu veikia keletas skirtingu veiksnių, todèl kiekvieno jų poveikị nustatyti labai sudètinga. Paveiksluose (2.2 pav. a, b, c; 2.3 pav. a, b; 2.4 pav.) pateikti keliu dangos ir kitus KDK sluoksnius veikiančių veiksnių scheminiai modeliai. KDK sluoksniai cikliškai veikiami TP ratų apkrovų silpsta 2.2 paveiksle (a) ir atsiranda atskirų KDK monolitinių sluoksnių nuovargis. KDK monolitiniu sluoksnių vertikalios plastinės deformacijos išjudina žemiau esančius biriuosius KDK sluoksnius. KDK sluoksnių vietose, kuriose cikliškai pasireiškia plastinès $A B$ sluoksnių deformacijos, nesurištų mišinių grūdeliai išsistumdo, o mišinio karkasas būna suardomas, KDK sluoksnis praranda pradinę laikomąą gebą. Dèl to prasideda KDK irtis. Pamažu KDK sluoksnių nuovargis perduodamas aukštesniems sluoksniams. Sumažejus visuminiam KDK stipriui blogèja KD eksploataciniai rodikliai: $\mathrm{AB}$ dangoje susiformuoja pažaidos, blogejja $\mathrm{KD}$ lygumas. $\mathrm{AB}$ dangos ir KDK būklę blogina kelių veiksnių, veikiančių tuo pačiu metu, bendrasis 
poveikis: $\mathrm{AB}$ dangą ir KDK vienu metu veikiant klimato bei oru veiksniams ir transporto priemoniu apkrovoms, bendrasis neigiamas (ardomasis) poveikis gali būti daug žalingesnis negu veikiant kiekvienam veiksniui atskirai.

a)

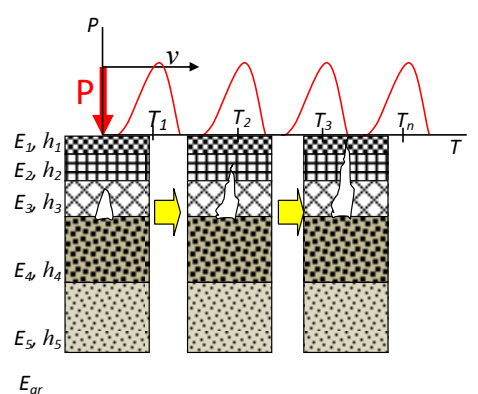

b)

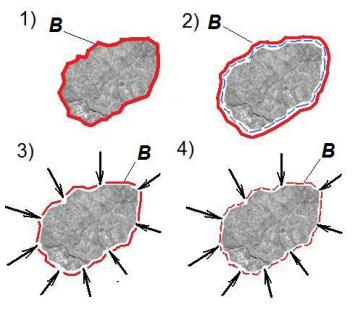

c)

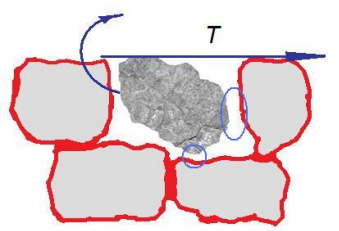

2.2 pav. Monolitinius kelio dangos konsrukcijos sluoksnius veikiančių veiksnių scheminis modelis: $E_{1}-E_{5}$ ir $h_{1}-h_{5}-$ atitinkamai KDK nurodytų sluoksnių tampros moduliai ir sluoksnių storiai; $E_{g r}$ ir $h_{g r}$-atitinkamai $\breve{Z} S$ grunto tampros modulis ir aktyviosios zonos sritis; $P$ - TP rato apkrova; $v$ - TP judejjimo vektorius; $T_{1}-T_{\mathrm{n}}$ TP rato ciklinès apkrovos poveikio trukmè; $B$ - bituminio rišiklio plèvelè; $T$ - TP ratu judèjimo kryptis

Fig. 2.2. Schematic model for the service life of asphalt concrete pavement structural layers and its influencing factors: $E_{1}-E_{5}$ ir $h_{1}-h_{5}$ - moduli of elasticity of the respective pavement structural layers and their thicknesses; $E_{\mathrm{gr}}$ ir $h_{\mathrm{gr}}$ - modulus of elasticity of the respective subgrade; $P$ - vehicle wheel load; $v$ - vehicle movement vector; $T_{1}-T_{\mathrm{n}}$ impact duration of the cyclic load caused by vehicle wheel; $B$ - membrane of bitumen binder; $T$ - vehicle movement direction

Pavyzdžiui, vasarą, kai būna aukšta oro temperatūra $\left(t \geq+30{ }^{\circ} \mathrm{C}\right), \mathrm{AB}$ danga išyla iki $t \geq+60{ }^{\circ} \mathrm{C}$. Dèl šios priežasties labai sumažèja KDK stipris, ir transporto priemonių apkrovų poveikis $\mathrm{AB}$ dangai ir KDK būna daug stipresnis negu to paties dažnio ir dydžio apkrovų poveikis $A B$ dangai ir KDK žiemą. Tačiau daugkartinis vandens ir šalčio poveikis bitumo plèvelei, padengusiai $A B$ mišinio grūdelius, ją taip pat ardo (2.2 pav. b: 1, 2, 3, 4). Vandens plèvelè, veikiant važiuojančių $\mathrm{TP}$ ratams, ardo $\mathrm{AB}$ devimaji sluoksnị. Dèl to vanduo patenka tarp bitumo plèvelès ir grūdelio. Veikiant šalčio ciklams susidaro ledo lęšiai, kurie suardo bitumo plèvelę ir apnuogina grūdelio paviršių. Tuo pačiu metu $\mathrm{AB}$ danga, veikiama oro temperatūros, deguonies ir saulès spinduliuotès, labai intensyviai senejja, todèl dangos irties procesas dar labiau suintensyvejja. $\mathrm{AB}$ dangos senejjimo procesas, dèl oro sąlyčio su danga vykstant konvekcijos

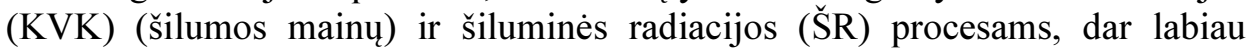
suintensyvejja. Iš dangos asfaltbetonio daug intensyviau garuoja lakios bitumo 
frakcijos - alyvos. Šio proceso metu grupinè bitumo sudètis pasikeičia - dalis smalų tampa asfaltenais, o dalis alyvų - smalomis, todèl procentinè asfaltenų dalis padidèja, o alyvų sumažeja. Šiam procesui intensyviai vykstant 3-5 metus, dangos asfaltbetonio atsparumas gniuždymui labai padideja, o elastingumas ir atsparumas tempimui sumažeja. Dangos asfaltbetonis iš tampraus, elastingo ir plastiško gali tapti trapus, dẻl šios priežasties $A B$ danga gali pradèti trūkinèti. Šaltuoju metų laikotarpiu (esant neigiamai oro ir AB dangos temperatūrai) AB dangos irti dèl nuovargio (daugkartinio transporto priemonių apkrovų poveikio) labai suintensyvina oro temperatūros pokyčiai iš teigiamosios į neigiamają ir iš neigiamosios $\mathfrak{i}$ teigiamają, nes danga patiria irties (dèl vandens ir šalčio įtakos) poveikị: $A B$ porose (tuštymèse) esantis vanduo užšaldamas didina savo tūrị ir ardo dangos asfaltbetonį. Mineralinès medžiagos grūdeliams netekus bitumo plèvelès, susilpnèja jų saveikos kontaktai ir važiuojančių TP ratai juos išplèšia ir $\mathrm{AB}$ dangos.

a)

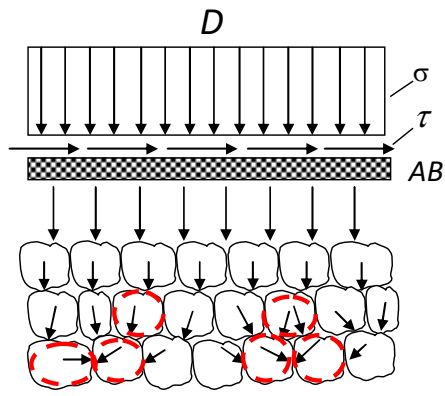

b)

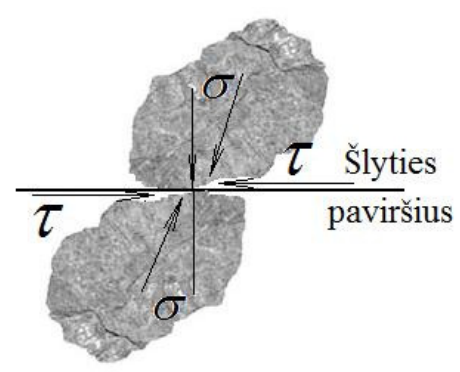

2.3 pav. Nerišliujų kelio dangos konsrukcijos sluoksnius veikiančių veiksnių funkcionavimo scheminis modelis: $D$ - TP rato veikimo zona; $\mathrm{AB}$ - asfaltbetonio danga; $\sigma-$ normaliniai itempiai; $\tau$ - tangentiniai (šlyties) įtempiai

Fig. 2.3. Schematic model for the service life of unbound pavement structural layers and their influencing factors: $D$-the area of vehicle wheel action; $\mathrm{AB}$ - asphalt concrete pavement; $\sigma$ - normal stresses; $\tau$ - tangential (shear) stresses; $P$ - vehicle wheel load

KDK konstrukcijos nerišliuosius sluoksnius važiuojančių TP ratai veikia normaliniais įtempiais (išskirstyta apkrova). Veikiančios apkrovos perduodamos žemiau esantiems KDK sluoksniams išjudinami nerišliuose KDK sluoksniuose sukibęs grūdeliai. Jie pradeda judèti vienas kito atžvilgiu. Pasireiškus šiems veiksniams nerišlioje KDK sluoksnyje, tarp judančių grūdelių atsiranda šlyties jègos. Silpniems grūdeliams trinantis vienam i kitą, jų aštrios briaunos suapvaleja, dèl to susilpnèja jų tarpusavio sąlytis (šlyties jègos). Nesukimbantys pradeda judèti, o tai suardo sluoksnio medžiagos karkasą ir nerišlus KDK sluoksnis praranda savo stiprị. 



2.4 pav. Provėžų susidarymo monolitinejje tampriojoje kelio dangoje modelis: 1 proceso pradžia; 2 - įsisenèjęs procesas po kelerių (3-5 ar daugiau) metų; $P$ - TP rato apkrova

Fig. 2.4. The model of rutting in flexible road pavement: 1) beginning of the process;

2 ) the long-time process after several (3-5 or more) years, $P$ - vehicle wheel load

Vykstant TP eismui, monolitiniuose tampriuose KDK sluoksniuose surištieji AB grūdeliai rato veikimo zonoje yra gniuždomi. Gniuždomi grūdeliai perduda apkrovas šalia esantiems grūdeliams kurie nuo savęs stumia toliau esančius grūdelius. Grūdeliams išsistumdžius iš savo vietos $A B$ karkasas tampa ne homogeniškas. TP rato veikimo vietose grūdeliai išretejja, išsistumdo i šonus, o šonuose esantys grūdeliai susistumia arčiau vienas kito. Vietose, kuriose grūdeliai išretejja, atsiranda tuštymių, o vietose, kuriose jie sutankèja prasideda jų irtis. Silpni grūdeliai, gniuždant vienam kitą, trupa ir smulkejja. AB danga praranda savo stiprị, ir atsiranda jos nuovargis. Pasireiškus tokiam grūdelių judejjimui $\mathrm{AB}$ dangoje susidaro vèžès (provèžos).

$\mathrm{AB}$ dangos ir KDK būklę apibūdina šie jų rodikliai:

- $\mathrm{AB}$ dangos būklę, KD eksploataciniai rodikliai: dangos lygumo $Y$ rodikliai (plačiausiai naudojamas rodiklis - lygumas pagal indeksą IRI $Y_{I R I}, \mathrm{~m} / \mathrm{km}$ ); dangos véžètumo rodikliai (dažniausia naudojamas rodiklis - vèžès gylis $H_{V}, \mathrm{~mm}$ ), dangos defektingumo rodikliai (patogiausias rodiklis - dangos suirties mastas $D_{D}$, išreikštas suirusios dangos ploto dalimi, \%) ir kt;

- KDK būklę: kelio konstrukcijos (KK) tampros modulis $E_{K}, \mathrm{MPa}$; kelio konstrukcijos stiprio koeficientas $K_{s t}$; dangos ir KDK defektingumo rodikliai (patogiausias rodiklis - suirties mastas $D_{K}$, išreikštas suirusios dangos ir KDK ploto dalimi, \%) ir kt.

$\mathrm{AB}$ dangos ir KDK svarbiausios savybès apibūdina jų gebą ilgą laiką ( $\mathrm{AB}$ dangai laiką $T_{D} \geq 6-8$ metus, KDK laiką $T_{K} \geq 8-10$ metu) priešintis transporto priemoniu apkrovu ir aplinkos veiksnių (tarp jų-klimato ir orų veiksnių) poveikiui ir šiuos poveikius atlaikyti, nesuardžius $A B$ ir kitų KDK sluoksnių medžiagų struktūros ar kitaip nepakeitus šių medžiagų savybių: 
- $\mathrm{AB}$ dangos būklès savybès apibūdinamos taip: dangos pradinio, pasiekiamo įrengus dangą, lygumo blogèjimo rodikliu $\Delta Y_{I R I}$, išreiškiamu dangos lygumo pablogèjimu, $\mathrm{m} / \mathrm{km}$ (vidutiniškai) per metus; dangos irties $D_{D}$ didejjimo rodikliu $\Delta D_{D}$, išreiškiamu suyrančios dangos per metus ploto \% (suirusios dangos ploto padidèjimu, absoliučiais defektų ploto $\%$, vidutiniškai per metus); dangos véžètumo $H_{V}$ didejjimo rodikliu $\Delta H_{V}$, išreiškiamu dangos vèžès gylio padidejimu, $\mathrm{mm}$ (vidutiniškai) per metus; dangos asfaltbetonio atsparumo nuovargiui rodiklio pradinès vertès $N_{c}^{(p r)}$ mažejjimo rodikliu $\Delta N_{c}$, nuovargio ciklais (vidutiniškai per metus); $\mathrm{AB}$ dangos kiekvieno sluoksnio tampros modulio pradinès vertès $E_{A B}^{(p r)}$ mažèjimo rodikliu $\Delta E_{A B}, \mathrm{MPa}$ (vidutiniškai per metus) ir kt;

- tampriosios KDK eksploatacinès savybès apibūdinamos taip: kelio konstrukcijos (KK) stiprio koeficiento pradinès vertès $K_{s t}^{(p r)}$ mažejjimo rodikliu $\Delta K_{s t}$, vieneto dalimis (vidutiniškai per metus); KK tampros modulio pradinès vertès $E_{K}^{(p r)}$ mažèjimo rodikliu $\Delta E_{K}, \quad \mathrm{MPa}$ (vidutiniškai per metus) ir kt.

Žinant pradines rodiklių $D_{D}, D_{K}, Y_{I R I}, H_{V}, h_{n}, N_{c}, E_{A B}, K_{s t}, E_{K}$ vertes $D_{D}^{(p r)}, Y_{I R I}^{(p r)}, H_{V}^{(p r)}, h_{n}^{(p r)}, N_{c}^{(p r)}, E_{A B}^{(p r)}, K_{s t}^{(p r)}, E_{K}^{(p r)}\left(D_{D}^{(p r)}=0 ; H_{V}^{(p r)}=0 ;\right.$ $\left.h_{n}^{(p r)}=0\right)$, jos nustatomos atlikus tyrimus arba žinomos iš anksčiau atliktu tyrimų gautų rezultatų, taip pat žinant šių rodiklių leidžiamąsias vertes $D_{D}^{(l)}$, $Y_{I R I}^{(l)}, H_{V}^{(l)}, h_{n}^{(l)}, N_{c}^{(l)}, E_{A B}^{(l)}, K_{s t}^{(l)}, E_{K}^{(l)}$ (metams bėgant nurodytų rodiklių vertès blogèja - jų leidžiamosios vertès paimamos iš norminių dokumentų, jeigu kurio nors rodiklio (ar kelių rodiklių) leidžiamosios vertès (leidžiamujų verčių) norminiuose dokumentuose nèra, šios vertès nustatomos atlikus specialiuosius tyrimus) ir žinant nurodytų rodiklių savybių blogèjimo vidutines vertes $\Delta D_{D}$, $\Delta Y_{I R I}, \Delta H_{V}, \Delta h_{n}, \Delta N_{C}, \Delta E_{A B}, \Delta K_{s t}, \Delta E_{K}$ (jos nustatomos iš specialiujuc tyrimų rezultatų), pagal siūlomas formules nustatomi $\mathrm{AB}$ dangos ir KDK tarpremontiniai laikotarpiai, išreikšti metais, kuriems einant užtikrinamos nurodytų rodiklių leidžiamosios vertès (Petkevičius 2010).

\subsection{Kelių tampriosios dangos konstrukcijų funkcionavimo trukmè}

Nustatant tampriosios AB ar kitos asfaltinès dangos ir KDK būklę, patogiausi šie rodikliai: 
- AB dangos būklei $Y_{I R I}^{(1)}, D_{D}^{(1)}, H_{V}^{(1)}$;

- KDK būklei - $K_{s t}^{(1)}$, (jie aptarti 2.1 poskyryje).

Kelių dangos (KD) funkcionavimo trukmè $T$ būna ne mažesnè už numatytą racionalią jos funkcionavimo trukmę $T^{(r)}\left(T \geq T^{(r)}\right)$ tik tuo atveju, kai numatyto laikotarpio pabaigoje jos faktinis lygumas $Y_{I R I}^{(f)}$ būna ne blogesnis už leidžiamaji jos lygumą $Y_{I R I}^{(k r)} \quad\left(Y_{I R I}^{(f)} \leq Y_{I R I}^{(k r)}\right)$. Laikui bėgant, KD, funkcionuojančios $T$ metų, lygumas nuolat ir nenutrūkstamai blogejja. Praejjus tam tikram laikotarpiui (keleriems ar keliolikai metų) KD faktinio lygumo rodiklio vertè $Y_{I R I}^{(f)}$ padidèja nuo pradinès vertès $Y_{I R I}^{(f)}=Y_{I R I}^{(1)}$ iki jo kritinès vertès $Y_{I R I}^{(f)}=Y_{I R I}^{(k r)}$ ir dideja toliau $Y_{I R I}^{(f)}>Y_{I R I}^{(k r)}-$ tuo momentu pasibaigia KD racionali funkcionavimo trukmé $T^{(k r)}$ ir dangą būtina nedelsiant suremontuoti. Suremontavus dangą, pagerinamas jos lygumas.

Šio rodiklio $Y_{I R I}$ vertes priklauso nuo transporto priemonių eismo intensyvumo $N$ (ypač nuo sunkiujų transporto priemonių (STP) eismo intensyvumo), nuo KD ir kitų KDK sluoksnių storio, sutankinimo laipsnio, sluoksnių medžiagų savybių, KDK stiprio ir kitų veiksnių.

Išanalizavus savo eksperimentinių tyrimų, atliktų automagistralèje KaunasMarijampolé-Suvalkai (A5) rezultatus, galima prognozuoti magistralinių kelių $\mathrm{AB}$ dangos lygumo kitejjimą penkeriems metams (su kaskart mažèjančia arba nekintančia KD tarpremontinio laikotarpio $T$ trukme), charakteringas KD lygumo kitejjimo grafinis modelis pateiktas 2.5 paveiksle.

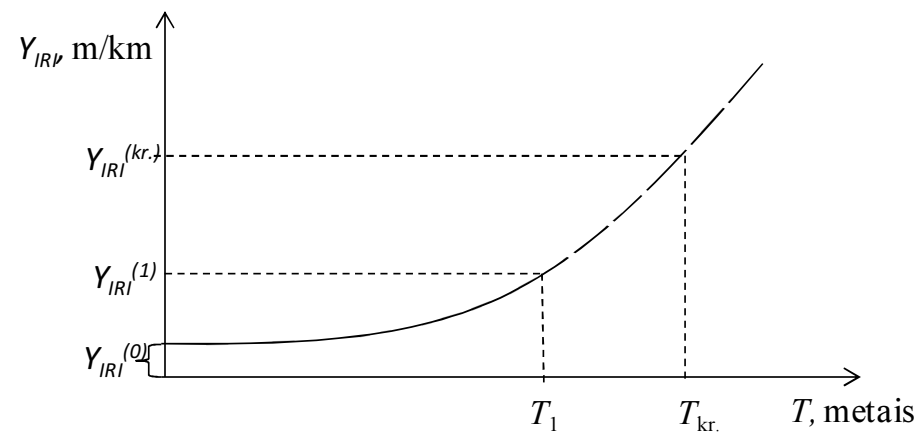

2.5 pav. Kelių dangos lygumo rodiklio kitejjimo laikui bėgant grafinis modelis

Fig. 2.5. Graphical model of the change in pavement roughness index in the course of time 
Kelio dangos (KD) eksploatacinis lygumo rodiklis $Y_{\mathrm{IRI}}^{(1)}$ kitejja nuo $\leq 1,0 \mathrm{~m} / \mathrm{km}$ iki $1,5-1,6 \mathrm{~m} / \mathrm{km}$ per trumpesnị laiką (4,5-5,0 metus) nei pirmasis tarpremontinis laikotarpis $T_{1}$ ir neviršija kritinès $Y_{\mathrm{IRI}}{ }^{(\mathrm{kr})}$ ribos.

Kelių dangos (KD) funkcionavimo trukmè $T$ būna ne mažesnė už numatytą racionalią jos funkcionavimo trukmę $T^{(r)}\left(T \geq T^{(r)}\right)$ tik tuo atveju, kai numatyto laikotarpio pabaigoje jos faktinis vèžetumo rodiklis $H_{V}^{(f)}$ būna ne blogesnis už leidžiamajji jos vèžètumo rodiklị $H_{V}^{(k r)}\left(H_{V}^{(f)} \leq H_{V}^{(k r)}\right)$. Laikui bėgant, KD, funkcionuojančios $T$ metų, vėžètumas nuolat ir nenutrūkstamai blogèja. Praejus tam tikram laikotarpiui (keleriems ar keliolikai metų) KD faktinio vèžètumo rodiklio vertè $H_{V}^{(f)}$ padideja nuo pradinès vertès $H_{V}^{(f)}=0$, dideja toliau iki tarpinès vertès (padidejus $T_{1}$ laikotarpiui) $H_{V}^{(f)}=H_{V}^{(1)}$ ir didèja iki kritinès vertès $H_{V}^{(f)}=H_{V}^{(k r)}$ bei didèja toliau iki vertès $H_{V}^{(f)}>H_{V}^{(k r)}$ - tuo momentu pasibaigia racionali KD funkcionavimo trukmé $T^{(k r)}$ ir ją būtina nedelsiant suremontuoti. Suremontavus dangą, pagerinamas jos skersine kelio kryptimi.

Rodiklio $H_{V}$ vertès taip pat priklauso nuo transporto priemoniu eismo intensyvumo $N$ (ypač nuo sunkiujų transporto priemonių (STP) eismo intensyvumo), nuo KD ir kitu $\mathrm{KDK}$ sluoksnių storio, sutankinimo laipsnio, sluoksnių medžiagų savybių, KDK stiprio ir kitų veiksnių.

Išanalizavę savo eksperimentinių tyrimų, atliktų kelyje KaunasMarijampolé-Suvalkai (A5) rezultatus, galime prognozuoti magistralinių kelių $\mathrm{AB}$ dangos vèžètumo kitèjimą penkeriems metams (su kaskart mažèjančia arba nekintančia KD tarpremontinio laikotarpio $T$ trukme). Charakteringas KD vėžètumo rodiklios $H_{V}$ kitejjimo grafinis modelis pateiktas 2.6 paveiksle.

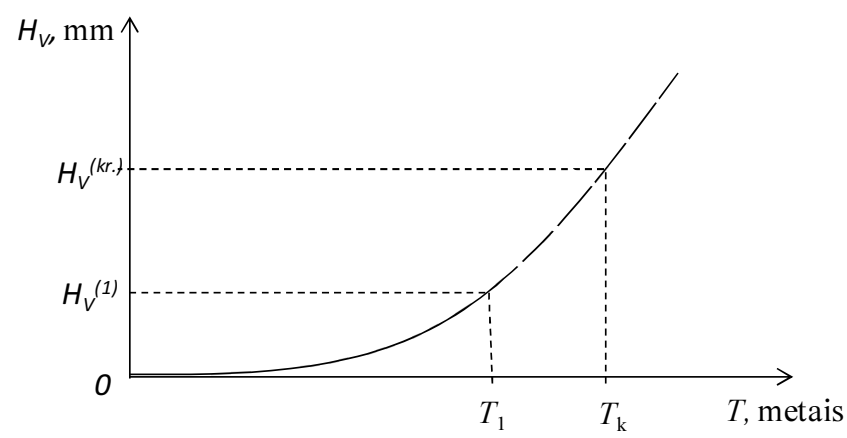

2.6 pav. Kelių dangos vèžètumo rodiklio kitèjimo laikui bẻgant grafinis modelis

Fig. 2.6. Graphical model of the change in pavement rutting index in the course of time 
Kelių dangos (KD) funkcionavimo trukmè $T$ būna ne mažesnè už numatytą racionalią jos funkcionavimo trukmę tuo atveju, kai numatyto laikotarpio pabaigoje jos faktinis suirties masto rodiklis $D_{D}^{(f)}$ būna ne blogesnis už leidžiamaji jos dydi $D_{D}^{(k r)}$. Laikui bėgant, KD, funkcionuojančios $T$ metų, suirtis nuolat dideja. Praejus tam tikram laikotarpiui, KD faktinio suirties masto verte $D_{D}^{(f)}$ padidèja nuo pradinès vertès $D_{D}^{(f)}=D_{D}^{(1)}$ iki jo kritinès vertès $D_{D}^{(f)}=D_{D}^{(k r)}$ ir dideja toliau $D_{D}^{(f)}>D_{D}^{(k r)}$ - tuo momentu pasibaigia KD racionali funkcionavimo trukmé $T^{(k r)}$ ir būtina dangą nedelsiant suremontuoti. Suremontavus dangą, pagerinama jos būklè.

Išanalizavę savo eksperimentinių tyrimų, atliktų kelyje KaunasMarijampolè-Suvalkai (A5) rezultatus, galime teigti, kad, praejjus penkeriems KD funkcionavimo metams, KD suirties mastas pasiekia tik nedidelę $D_{\mathrm{D}}=3 \%$. Charakteringas KD suirties masto $D_{D}^{(f)}$ kitejimo grafinis modelis pateiktas 2.7 paveiksle. Laikui bėgant, $\mathrm{KD}$, funkcionuojančios $T$ metų, lygumas $Y_{\text {IRI, }}$, věžètumas $H_{\mathrm{V}}$ ir suirties mastas $D_{\mathrm{D}}$ nuolat blogeja. Šių pagrindinių kelių dangos eksploatacinių rodiklių kompleksinis kitejimas rodo visos KDK stiprio koeficiento $K_{\text {st }}$ mažejjimą. Remiantis šia nuostata, galima teigti, kad, praejjus tam pačiam, kaip ir prieš tai analizuotų rodiklių, kitejjimo laikotarpiui, KD faktinio stiprio koeficiento vertė $K_{s t}^{(f)}$ mažèja. KDK stiprio koeficientas $K_{\text {st }}$ vertė mažèja nuo pradinès vertès $K_{s t}^{(f)}=K_{s t}^{(0)}$ iki tarpinès vertès (praejus $T_{1}$ laikotarpiui $K_{s t}^{(f)}=K_{s t}^{(1)}$ ir toliau mažèja iki jos kritinès vertès $K_{s t}^{(f)}=K_{s t}^{(k r)}$ bei mažèja toliau iki vertès $K_{s t}^{(f)}<K_{s t}^{(k r)}$ - tuo momentu pasibaigia KDK racionali funkcionavimo trukmè $T^{(k r)}$, todèl būtina dangą nedelsiant suremontuoti, o KDK - sustiprinti.

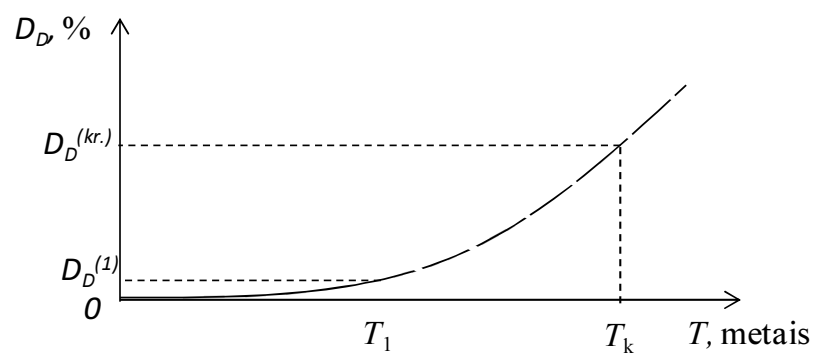

2.7 pav. Kelio dangos suirties masto kitèjimo laikui bègant grafinis modelis

Fig. 2.7. Graphical model of the change in pavement degradation extent in the course of time 
Charakteringas KDK stiprio koeficiento $K_{\mathrm{st}}$ kitejjimo grafinis modelis pateiktas 2.8 paveiksle.

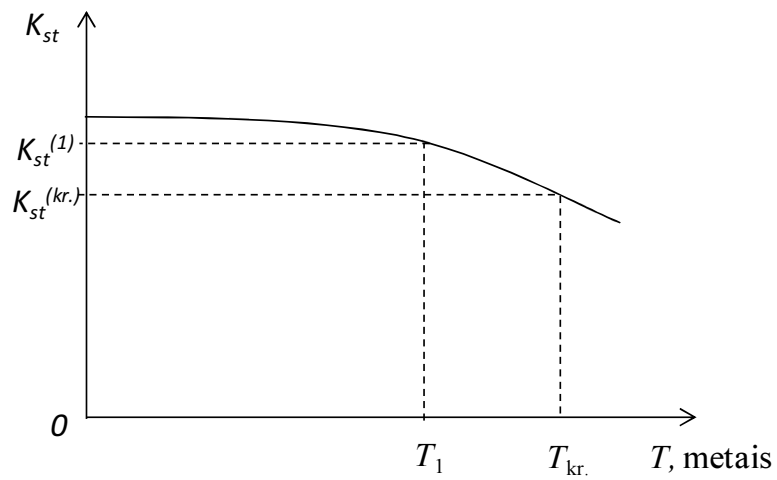

2.8 pav. Kelių dangos konstrukcijos stiprio koeficiento kitėjimo (laikui bėgant) grafinis modelis

Fig. 2.8. Graphical model of the change in the pavement structure strength coefficient in the course of time

Esant didelèms STP eismo intensyvumo $N$ ir jo didejimo vertèms, labai dažnai ekonomiškai tikslinga parinkti aukštos kokybès KDK sluoksniams įrengti naudojamas medžiagas ir nustatyti racionalius KDK sluoksnių storius.

\subsection{Kelių tampriosios dangos konstrukcinių sluoksnių projektavimo pagrindimas}

Projektuojant kelių tampriosios dangos konstrukcijas būtina atsižvelgti i du svarbiausius kriterijus:

- kelių dangos ilgalaikiškumą (sluoksnių storị, jų medžiagas);

- racionalią medžiagų kainą.

Optimizuojant kelių dangos konstrukcijų patikimumą jų projektavimo metu, galima išskirti dvi pagrindines tendencijas. Viena jų - racionali kaina, kuri galètu garantuoti konstruojamos KDK patikimumą, kita - siekis užtikrinti kuo didesnį KDK stiprį, esant toms pačioms KDK funkcionavimo sąlygoms. Racionalus sprendimas apibrèžia kriterijų, kuris rodo minimalias statybos išlaidas $K r_{\min }$, išlaikant reikiamą kelių dangos stiprį. Norint garantuoti kuo didesnį kelių dangos ilgalaikiškumą ir KDK funkcionavimo trukmę, reikia siekti išlaikyti kuo vienodesnius KDK sluoksnių projektinius parametrus. 
Tai galima pasiekti, pagerinant kokybès kontrolę, naudojant modernias kelių tiesybos mašinas, tobulinant kelių tiesybos technologijas ir garantuojant naudojamų medžiagų kokybès rodiklių didelị vienodumą.

Tam užtikrinti labai svarbu žinoti KDK viršutinio sluoksnio vienodumo itaką daugiasluoksnès sistemos homogeniškumui (pagal bendraji tampros moduli $E_{\mathrm{b}}$.

Tampros modulio $E_{\mathrm{b}}$ vienodumas priklauso nuo šių rodiklių:

žemiau paklotų sluoksnių tampros modulio $E_{2}$ vienodumo;

sluoksnị sustiprinančių medžiagų tampros modulio $E_{1}$;

KDK sluoksnių bendrojo storio $h$.

Funkcinį ryšį tarp šių verčių galima išreikšti per Barberio (2.1) formulę (Золотарев 2004).

$$
E_{b}=\frac{E_{1} E_{2}\left[1+\left(\frac{2 h}{D}\right)^{2}\left(\frac{E_{1}}{E_{2}}\right)^{2 / 3}\right]^{1 / 2}}{E_{1}-E_{2}\left\{1-\left[1+\left(\frac{2 h}{D}\right)^{2}\left(\frac{E_{1}}{E_{2}}\right)^{2 / 3}\right]^{1 / 2}\right\}} .
$$

Pagal tikimybių teoriją žinoma, kad atsitiktinio dydžio dispersija, kuri yra kelių kitų atsitiktinių, nekoreliuojančiujjų dydžių funkcija lygi dispersijų ir išvestinių (nuo atitinkamų kintamųjų kvadratų) sandaugų sumai. Kadangi dydžiai $E_{1}, E_{2}$ ir $h$ tarp nèra susiję, t. y. tarp savęs nekoreliuoja, gauname (Золотарев 2004).

$$
E_{b}=\sigma_{E_{1}}^{2}\left(\frac{\partial E_{b}}{\partial E_{1}}\right)^{2}+\sigma_{E_{2}}^{2}\left(\frac{\partial E_{b}}{\partial E_{2}}\right)^{2}+\sigma_{h}^{2}\left(\frac{\partial E_{b}}{\partial h}\right)^{2},
$$

čia $\sigma_{E_{1}}, \sigma_{E_{2}}, \sigma_{h}$ - skaičiuojamųjų rodiklių viršutinio sluoksnio tampros modulio $E_{1}$, žemiau esančių sluoksnių suminio tampros modulio $E_{2}$, viršutinio sluoksnio storio $h$ standartiniai nuokrypiai.

Apskaičiuojamos dalies išvestinė (Золотарев 2004).

$$
\begin{aligned}
& \frac{\partial E_{b}}{\partial E_{1}}=\frac{3 E_{2}^{2} S\left(S^{1 / 2}-1\right)+E_{2}(S-1)\left(E_{1}-E_{2}\right)}{3 S^{1 / 2}\left(E_{1}-E_{2}+E_{2} S^{1 / 2}\right)^{2}}, \\
& \frac{\partial E_{b}}{\partial E_{2}}=\frac{E_{1}\left[1+\frac{2}{3}(S-1)\right]\left(E_{1}-E_{2}\right)+E_{1} E_{2} S}{S^{1 / 2}\left(E_{1}-E_{2}+E_{2} S^{1 / 2}\right)^{2}},
\end{aligned}
$$




$$
\frac{\partial E_{\text {sum }}}{\partial h}=\frac{E_{1} E_{2}(S-1)\left(E_{1}-E_{2}\right)}{h S^{1 / 2}\left(E_{1}-E_{2}+E_{2} S^{1 / 2}\right)^{2}} .
$$

Formulèse (2.3), (2.4), (2.5) $S$ vertè apskaičiuojama iš (2.7) formulès.

$$
S=1+\left(\frac{2 h}{D}\right)^{2}\left(\frac{E_{1}}{E_{2}}\right)^{2 / 3},
$$

čia $D$ - apskritimo, atitinkančio rato įspaudą dangoje, skersmuo.

Iš (2.1)-(2.6) pateiktų formulių galima gauti bendrojo tampros modulio $E_{\mathrm{b}}$ variacijos koeficiento $V_{E_{b}}$ priklausomybę dvisluoksnei sistemai nuo sustiprinto sluoksnio tampros modulio variacijos koeficiento $V_{E_{1}}$, bendrojo žemiau pakloto sluoksnio tampros modulio variacijos koeficiento $V_{E_{2}}$ ir viršutinio sluoksnio storio variacijos koeficiento $V_{h}$.( Золотарев 2004).

$$
V_{E_{b}}=V_{E_{K}}=\frac{\partial E_{b}}{E_{b}}=\frac{\left[\left(V_{E_{1}} E_{1} \frac{\partial E_{b}}{\partial E_{2}}\right)^{2}+\left(V_{E_{2}} E_{2} \frac{\partial E_{b}}{\partial E_{2}}\right)^{2}+\left(V_{h} h \frac{\partial E_{b}}{\partial h}\right)^{2}\right]^{1 / 2}}{E_{b}} .
$$

Priklausomybė (2.7) leidžia tirti skaičiuojamujų rodiklių $V_{E_{1}}, V_{E_{2}}$ ir $V_{h}$ ịtaką variacijos koeficiento $V_{E_{b}}=V_{E_{K}}$ vertèms. Atlikus apskaičiavimus su skirtingais rodikliu variacijos koeficientais $V_{E_{1}}, V_{E_{2}}, V_{h}$, gauti rezultatai parodè, kad daugiausia itakos tampros modulio $E_{\text {sum }}$ vienodumui turi apatinio sluoksnio rodiklių vienodumas. Tai dar kartą irodo būtinybę, kad tiesiant kelius būtų užtikrintas kuo geresnis kiekvieno kelių dangos konstrukcinio sluoksnio homogeniškumas ir žemès sankasos grunto kokybès rodiklių vienodumas. Dvigubai didinant važiavimų tankinimo volu skaičių, grunto tankio rodiklio variacijos koeficientas sumažeja apie 20 \% (Золотарев 2004).

Daugelio autorių tyrimai parodè, kad kelių dangos konstrukcijų sluoksnių storio ir jo tampros modulio vienodumas turi įtakos dvisluoksnès dangos vienodumui (Золотарев 2004).

Vertinant daugiasluoksnę dangą, kaip pamažu vieną ant kito KDK sluoksnio ịrengiamą kelio dangos konstrukciją, galima nustatyti galimus verčių $V_{E_{1}}, V_{E_{2}}$ ir $V_{h}$ pokyčius.

Eksploatavimo metu kelių dangos homogeniškumas gali būti išlaikytas, jeigu laiku atliekama sisteminga ir tinkama (atitinkanti norminius dokumentus) kelių priežiūra. 
Tampriosios kelių dangos konstrukcijos sluoksnių optimizavimo uždavinys gali būti išspręstas, ịvertinus sluoksniams įrengti naudojamų medžiagų savybes ir nustatant optimalų šių sluoksnių storį.

Daugelyje Vakarų Europos šalių ir JAV kelių dangos ir KDK būklè vertinama naudojant kompleksinius rodiklius. Plačiausiai žinomas Amerikos (JAV) Kelių ir transporto pareigūnų asociacijos (AASHO) nustatytas eksploatacinio patikimumo (eksploatacinès būklès) rodiklis $p$. Kelių nestandžios dangos konstrukcijoms rodiklis $p$ nustatomas iš formulès (Haas et al. 1994).

$$
p=5,03-1,91 \lg (1+S V)-0,01 \sqrt{C+P}-1,38(R D)^{2},
$$

čia $S V$ - dangos lygumo rodiklis, ivvertinamas laboratoriniu profilometru pagal važiuojamosios dalies nelygumų nuolydžio pokytị, $C-$ plyšių skaičius, $\mathrm{m} / 1000 \mathrm{~m}^{2}, P$ - užtaisytų dangos išdaužų santykinis plotas, $\mathrm{m}^{2} / 1000 \mathrm{~m}^{2}, R D-$ vidutinis věžès gylis.

Kai rodiklio vertė $p=2,5$ kelių dangą dar leidžiama eksploatuoti. Tampriosios KDK eksploatavimo pradžioje rodiklio $p$ vertès turi būti $p \geq 4,2$.

Rodiklis $p$ nustatomas ir iš šios formulès: (Haas et al. 1994).

$$
p=11,683-3,9 \lg R-0,01 \sqrt{3,08 C+P}-0,241(R D)^{2},
$$

čia $R$ - dangos lygumas, nustatytas smūgiamačiu, kiti rodikliai tie patys kaip (2.8) formulèje.

Šị rodiklị $p$ kompleksiniu keliu būklès rodikliu vadinti negalima, nes jis ịvertina tik kelių dangos būklę. Svarbiausias kelių vertinimo rodiklio $p$ ir jo modifikaciju trūkumas - jų empiriškumas. Juos galima taikyti tik tomis konkrečiomis sąlygomis, kurios buvo juos nustatant. Eksploatacinei keliu dangos būklei ịvertinti patogu turèti apibendrintą universalų rodiklị, ịvertinantị kelių dangos lygumą ir KDK stipri bei kitas svarbias kelių eksploatacines savybes.

\subsection{Kelių tampriosios dangos racionalių konstrukcijų parinkimas}

Siekiant parinkti racionalią kelių dangos konstrukciją, pravartu išanalizuoti realiai egzistuojančią (ir ne trumpiau negu 5 metus funkcionuojančią) kelių dangos konstrukciją. Šiam tikslui pasiekti reikalingi ne tik KDK sluoksnių ir jų medžiagų kokybès rodiklių projektinès vertės, esamos kelių dangos būklès tyrimai, bet ir kelių dangos konstrukcijų (KDK) naudotų medžiagų kokybès.

Svarbiausią racionalios konstrukcijos parinkimo principą galima užrašyti taip: 


$$
\text { racionali } K D K=\frac{\text { rezultatas }}{\text { išlaidos }} \text {. }
$$

Racionaliausias (optimalus) kelių dangos konstrukcijos sprendinys bus tas, kurio rezultato ir jam pasiekti reikalingų išlaidų santykis bus mažiausias. Rezultatas KDK funkcionavimo trukmè. Ji turi būti racionali, o jai pasiekti reikiamos lèšos optimalios (2.9 pav).



2.9 pav. Racionalios kelių dangos konstrukcijos parinkimo grafinis modelis, ìvertinant KDK funkcionavimo pobūdi

Fig. 2.9. Graphical model for the operation of rational road pavement structure

Mokslo ir pasaulinè patirtis rodo, kad racionali būna ta $\mathrm{KDK}$, kurios funkcionavimo trukmè (esant dideliam TP eismo intensyvumui) būna gana ilga (galimai kuo ilgesnè, kai dangos būklè išlikusi gera).

Atliekant KDK medžiagų tyrimų rezultatų analizę, būtina suskirstyti kelią i ruožus su vienodu eismo intensyvumu. Kadangi svarbiausi rodikliai, nurodantys kelių dangos būklę yra dangos lygumas $Y_{\text {IRI }}$, vèžètumas $H_{\mathrm{V}}$ ir suirties mastas $D_{D}$, turi būti rasta analizuojamo kelio tiesybai naudotų medžiagų savybių ir KDK sluoksnių storių įtaka kelių dangos eksploataciniams rodikliams. Nustačius KD kokybės rodiklių matavimų vietas, kuriose buvo imti medžiagų bandiniai (jų kokybès kontrolei), tolesnei analizei sudaryta lygtis. Ji turi įvertinanti KD būklę, pagal analizuotų medžiagų kokybės rodiklius. Principinė racionalios kelių dangos konstrukcijos parinkimo lygtis:

$$
K_{K D}^{(r)}=a+b \cdot K_{A M}^{(r)}+c \cdot K_{A S}^{(r)}+d \cdot h_{A S}^{(r)}+e \cdot K_{P M}^{(r)}+f \cdot K_{P S}^{(r)}+g \cdot h_{P S}^{(r)},
$$

čia $K_{K D}^{(r)}$ - kelių dangos eksploatacinis rodiklis; $K_{A M}^{(r)}$ - asfaltinio mišinio kokybès rodiklis; $K_{A S}^{(r)}$ - asfaltbetonio sluoksnio kokybès rodiklis; $h_{A S}^{(r)}$ asfaltbetonio sluoksnio storis; $K_{P M}^{(r)}$ - kelių dangos pagrindo medžiagos kokybės rodiklis; $K_{P S}^{(r)}-$ kelių dangos pagrindo sluoksnio kokybès rodiklis; $h_{P S}^{(r)}-$ kelio 
pagrindo sluoksnio storis; a - laisvasis narys, $b, c, d, e, f, g$ - koeficientai, kuriu racionalias vertes išsprendus lygti, reikia nustatyti.

\subsection{Antrojo skyriaus išvados}

1. Asfaltinès dangos ir kelių dangos konstrukcijų eksploatacinès savybès priklauso nuo daugelio veiksnių: dangos bei kelių dangos konstrukcijų sluoksnių medžiagų ir žemès sankasos gruntų savybių, jų sluoksnių storio ir jų sutankinimo lygio, klimato veiksnių, transporto priemonių apkrovu bei nuo vietos sąlygu (gruntinio vandens lygio ir vietovès drèkinimo sąlygų). Viršutinio asfaltinès dangos sluoksnio eksploatacines savybes geriausiai apibūdina dangos lygumo, vėžètumo ir suirties masto rodikliai.

2. Asfaltinès dangos ir kelių dangos konstrukcijų svarbiausios savybės parodo dangos ir kelių dangos konstrukcijų gebą priešintis transporto priemonių apkrovų ir aplinkos veiksnių poveikiui ir šiuos poveikius atlaikyti, nesuardžius asfaltinių ir kitų sluoksnių medžiagų struktūros ar kitaip nepakeitus šių medžiagu savybių. Šią gebą objektyviai parodo asfaltinès dangos lygumo blogejimo, jos irties didejjimo ir jos věžètumo didejjimo rodikliai.

3. Priklausomai nuo kelių dangos konstrukcijų funkcionavimo sąlygų (transporto priemonių eismo intensyvumo, jų srauto sudèties ir kt.) kitejimo, ekonominio tikslingumo ir kitu veiksnių, laikui bėgant, tos pačios kelių dangos konstrukcijų atskirų ruožų tarpremontinių laikotarpių trukmė gali būti vienoda, tačiau gali ir gerokai (keleriais metais) skirtis.

4. Geriausias kelių asfaltinès dangos lygumas ir mažiausias provėžų gylis, dangą įrengus ir ją eksploatuojant bei ilgesne jos funkcionavimo trukmé pasiekiama, susiejus asfaltinio mišinio kokybès rodiklių ir kelių dangos konstrukcinių sluoksnių storių vertes su asfaltinès dangos lygumu bei vèžètumo rodikliu, bei šiuos duomenis naudojant naujoms KDK projektuoti ir ịrengti. 


\section{Konstrukcinių sluoksnių ir jų medžiagu savybių tyrimai}

Skyriuje apibūdintos kelio tyrimų ruožų projektinè ir faktinės konstrukcijos, aptarti $\mathrm{AB}$ dangos eksploataciniu rodiklių, konstrukcinių sluoksnių ir jiems naudotų medžiagų savybių bandymų ir matavimų metodai, sudaryta eksperimentiniu tyrimu sekos schema. Pateikta metodika tyrimu duomenims apdoroti. Išanalizuoti kelio dangos konstrukcijos medžiagu geometriniai (formos rodiklio $S I$, plokštumo rodiklio $F I$ ), mechaniniai (atsparumo smūgiams $S Z$, trupinimui $L A$, puoliruojamumui $P S V$, dèvejjimuisi $M_{\mathrm{DE}}$, šalčio ir šilumos ciklų poveikiui $F$ ), fiziniai (tankio $\rho$ ) rodikliai ir jų verčių sąveika.

Skyriaus tematika paskelbti penki autoriaus straipsniai kartu su bendraautoriais (Bulevičius et al. 2010a; Булявичюс et al. 2010b; Bulevičius et al. 2011a, 2011b 2013).

\subsection{Tyrimų atlikimo ir duomenų apdorojimo metodika}

Pirmajame ir antrajame skyriuose, analizuojant skirtingus literatūros šaltinius, buvo nustatyti pagrindiniai KDK sluoksnių ir jų medžiagų savybių veiksniai, turintys įtakos eksploataciniams kelių dangos rodikliams, t. y.: asfaltinès dangos suirties masto $D_{D}$, dangos vèžètumo rodiklio $H_{\mathrm{V}}$ ir jos lygumo rodiklio $Y_{\text {IRI }}$ 
vertėms. Tiriant automobilių kelių $\mathrm{AB}$ dangos būklę, naudotas pasaulyje labiausiai paplitęs ir efektyviausias kompleksinis kelių dangos būklès vertinimo būdas. KD matavimai atlikti naudojant mobiliają kelių tyrimų laboratoriją RST28. Tyrimams atlikti buvo sudaryta eksperimentiniu tyrimu sekos schema pateikta 3.1 paveiksle.



3.1 pav. Eksperimentinių tyrimu sekos schema

Fig 3.1. The scheme for the sequence of experimental research 
Išanalizavus Lietuvos magistralinių kelių tinklą, TP eismo intensyvumą (VMPEI) ir sudètị, buvo parinkti tyrimams tinkami kelių ruožai. Lietuvoje didžioji dalis magistralinių kelių nutiesta daugiau kaip prieš 20 metų, tuo metu galiojusieji norminiai dokumentai, reikalavimai ir bandymų standartai šiuo metu pasikeitę arba netaikomi.

Nauji norminiai dokumentai, kuriuose nurodyti reikalavimai, keliami medžiagoms, naudojamoms keliams tiesti, buvo pradèti naudoti nuo $2005 \mathrm{~m}$. Tuo laikotarpiu pradèti taikyti Europos normų bandymų metodai, atliekant tinkamumo ir kontrolès bandymus, kurie taikomi iki šiol. Siekiant mokslinio darbo rezultatų praktiškumo ir norint ištirti KDK ruožus, kurie funkcionuoja ne trumpiau nei garantinis (galimas 5 metų tarpremontinis) laikotarpis, tyrimams parinkti 2005-2006 m įrengti kelio ruožai.

Tyrimui parinktas vienas svarbiausių (antrasis pagal eismo intensyvumo VMPEI rodiklį) magistralinis kelias Kaunas-Marijampole-Suvalkai (A5), kurio skirtingu ruožų rekonstrukcija atlikta 2005-2007 m. Eksperimentinis tyrimas buvo atliktas laboratorijoje ir kelyje Kaunas-Marijampolè-Suvalkai (A5) (VIA Baltica). Tyrimo metodiką sudaro dvi dalys: kelio dangos (KD) ir kelio dangos konstrukcijos (KDK) medžiagų kokybès rodikliu (KR) tyrimai laboratorijoje ir KD eksploatacinių rodiklių matavimas atlikus kelio rekonstrukciją.

Kelyje A5 $2007 \mathrm{~m}$. buvo atlikti ir įvertinti kelio dangos lygumo pagal $Y_{I R I}$, vèžès gylio rodiklio $H_{\mathrm{v}}$ ir suirties masto $D_{\mathrm{D}}$ (nesuirusios dangos $D_{D}<1 \%$, nedaug suirusios dangos $D_{D}=1-3 \%$, geros būklès dangos- $D_{D}=3-5 \%$, pakankamos būklès dangos $D_{D}=5-8 \%$, patenkinamos būklès dangos $D_{D}=8-12 \%$, ribinès (kritinès) būklès dangos $D_{D}=12-16 \%$, nepatenkinamos būklès dangos $D_{D}=16-20 \%$, blogos būklès dangos $D_{D}=20-25 \%$, labai blogos būklès dangos $D_{D}=25-30 \%$ ir visai blogos būklès dangos $D_{D}>30 \%$ ) matavimai, kurie tose pačiose vietose pakartotinai buvo atlikti $2010 \mathrm{~m}$.

Iš kelio dangos paimti bandiniai buvo ištirti laboratorijoje. Suskirsčius kelią A5 i ruožus su vienodomis KDK ir kelio geometrinemis charakteristikomis, parinkti kelio tyrimų ruožai. Kelio ruožai tyrimams buvo parinkti taip, kad jų VMPEI būtų skirtingas, o KDK ir naudotos medžiagos kuo vienodesnès. Bandinių atrankos vietos parinktos naudojant atsitiktinių skaičių lentelę. Tyrimų ruožų projektinè KD parodyta 3.2 paveiksle. Jame parodytos tirtų ruožų KDK sluoksnių medžiagos: 0/11 S-M (SMA $11 \mathrm{~S}$ ) - skaldos ir mastikos AB, skirtas sluoksniams, veikiamiems sunkiaja apkrova, kurio mineralinių medžiagų viršutinio sieto akutès dydis - $11 \mathrm{~mm}$; 0/22-A (AC $22 \mathrm{AS}$ ) - AB, skirtas $A B$ apatiniams sluoksniams, veikiamiems sunkiaja apkrova, kurio mineralinių medžiagų viršutinio sieto akutès dydis - $22 \mathrm{~mm}$; 0/32 CS (AC $32 \mathrm{PS}$ ) - AB, 
skirtas AB pagrindo sluoksniams, veikiamiems sunkiaja apkrova, kurio mineralinių medžiagu viršutinio sieto akutès dydis $-32 \mathrm{~mm}$; dolomito skalda 0/45 - dolomito skaldos mišinys, kurio mineralinių medžiagų viršutinio sieto akutès dydis - $45 \mathrm{~mm}$; smèlis $0 / 4$ - smèlis, kurio mineralinių medžiagų viršutinio sieto akutès dydis $-4 \mathrm{~mm}$.

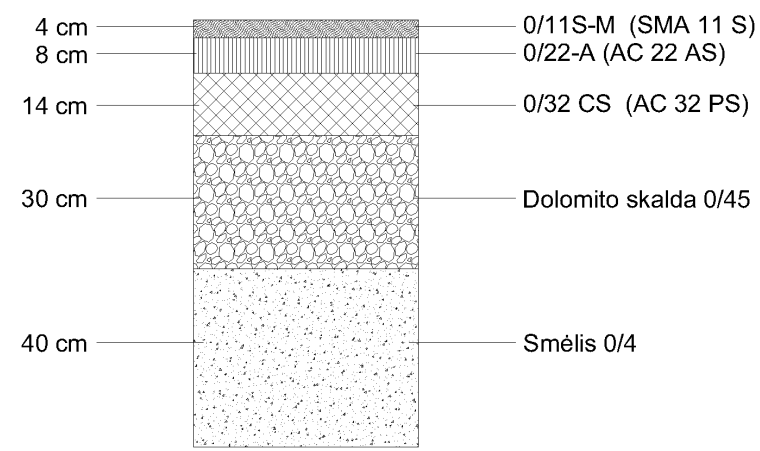

3.2 pav. Tyrimų ruožų kelių dangos konstrukcijos sluoksnių projektinès charakteristikos

Fig 3.2. Design characteristics of the pavement structural layers of experimental road sections

Tyrimų ruožų ilgiai pateikti 3.1 lenteleje. Vİ Transporto ir kelių tyrimo institutas (TKTI) kelyje Kaunas-Marijampolé-Suvalkai (A5) (VIA Baltica) $(2,4 \mathrm{~km}$ ir $30,0 \mathrm{~km}$ ) yra įrengusi TP sverimo postus, kuriuose nuolat sveriamos transporto priemonès. Pagal šių postų duomenis apskaičiuojamas TP eismo intensyvumas VMPEI.

3.1 lentelè. Magistralinio kelio Kaunas-Marijampolè-Suvalkai (A5) tyrimų ruožai ir jų ilgiai

Table. 3.1. The lengths of the experimental sections on the road A5 KaunasMarijampolè-Suvalkai

\begin{tabular}{|c|c|c|c|}
\hline Tyrimų ruožai & Ruožo pradžia, $\mathrm{km}$ & Ruožo pabaiga, $\mathrm{km}$ & Ruožo ilgis, $\mathrm{km}$ \\
\hline Pirmasis & 0,0 & 6,8 & 6,8 \\
\hline Antrasis & 25,8 & 30,3 & 4,5 \\
\hline
\end{tabular}

Šiuos tyrimus TKTI atlieka daugiau kaip 10 metų, todèl gauti duomenys yra patikimi ir naudojami analizuojant $\mathrm{TP}$ poveiki $\mathrm{AB}$ dangai. Tyrimų ruožų TP eismo intensyvumo kitejimas 2005-2012 m. parodytas 3.3 paveiksle. Duomenys kelio dangos konstrukcijos (KDK) sluoksnių medžiagų analizei buvo surinkti tose pačiose vietose $(\mathrm{Pk})$, kuriose, remiantis atsitiktinių skaičių lentele, buvo 
išmatuoti KDK sluoksnių ir jų medžiagų kokybės rodikliai (atlikus asfaltbetonio èminių tyrimus).

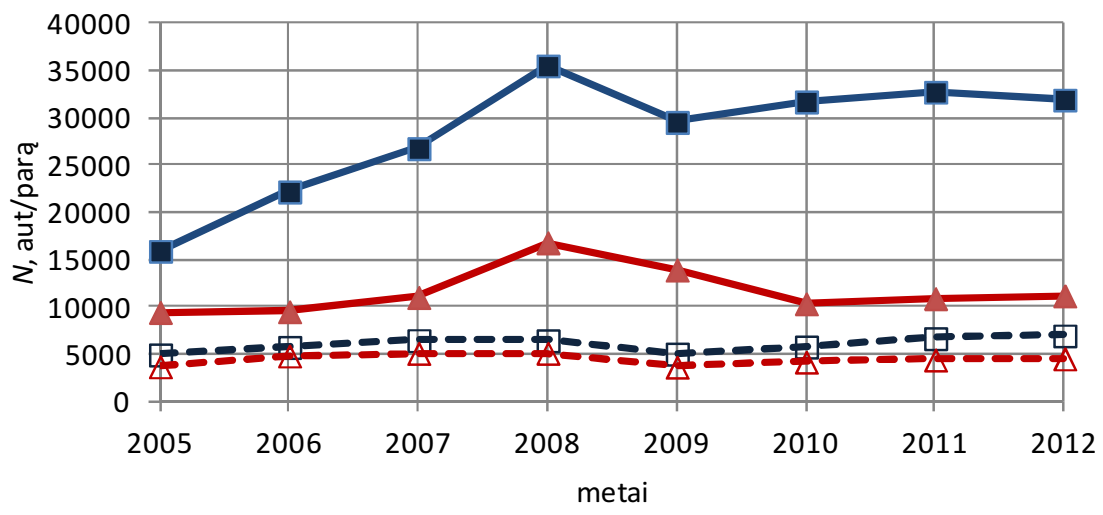

$\begin{array}{ll}- \text { - Bendras VMPEI ruože Nr. } 1 & -\Xi-\text { Krovininis VMPEI ruože Nr. } 1 \\ - \text { Bendras VMPEI ruože Nr. } 2 & -\Delta-\text { Krovininis VMPEI ruože Nr. } 2\end{array}$

3.3 pav. Tyrimų ruožų transporto priemonių eismo intensyvumo kitėjimas 2005-2012 m.

Fig. 3.3. Change in the traffic volume of the experimental road sections, 2005-2012

KDK sluoksniams įrengti naudotų medžiagų tyrimai laboratorijoje buvo atlikti pagal tuo metu galiojusiose statybos rekomendacijose R 35-01 nurodytus rodiklius, kurių dalis nepasikeite iki šiol, yra techninių reikalavimų apraše TRA ASFALTAS 08.

\subsubsection{Laboratorinių tyrimų metodai}

Asfaltinių mišinių bandiniai buvo imami iš medžiagos arti klotuvo sraigtų. Vienam $\mathrm{AB}$ bandymui, naudojant ėminiu èmimo kastuvą, buvo imami du elementarieji èminiai maždaug po $7 \mathrm{~kg}$ iš kiekvienos klotuvo pusès. Iš viso gaunami keturi elementarieji èminiai. Elementarusis èminys paimamas ịstumiant kastuvą i sraigto priekyje esančią dalį. Kai ji užsipildo, medžiagą iškeliama. Sumaišius elementariuosius èminius, suformuojamas reikiamos bandymams atlikti masès sudètinis èminys (LST EN 12697-27). I laboratoriją pristatytas èminys padalijamas (ketvirčiuojamas) dalimis šiems tolimesniems tyrimams atlikti:

- mineralinių medžiagų granuliometrinès sudèties ;

- bituminio rišiklio $B$ kiekio (skirtuminiu metodu), masès \%; 
- asfaltinio mišinio tariamojo tankio;

- asfaltinio mišinio didžiausio tankio;

- asfaltinio mišinio tuštymètumo rodiklio.

Atliekant bituminio rišiklio $B$ kiekio nustatymo tyrimą skirtuminiu metodu, asfaltinis mišinys ekstrahuojamas naudojant specialią (tam tikslui skirtą) laboratorinę irangą (3.4 pav., a).. Rišiklio $B$ kiekis(ekstrahavimo būdu) gaunamas rišiklį iš asfaltinio mišinio išplaunant tirpikliu. Rišiklio kiekis nustatomas skirtuminiu metodu pagal 3.1 formulę (LST EN 12697-1):

$$
S=\frac{100 \times\left[M-\left(M_{1}+M_{W}\right)\right]}{M-M_{W}},
$$

čia $S$ - tirpiojo rišiklio kiekis, \%; $M$ - neišdžiovintos bandomosios dalies masè, g; $M_{1}-$ regeneruotos mineralinès medžiagos masè, g; $M_{\mathrm{W}}-$ neišdžiovintos bandomosios dalies vandens masé, $\mathrm{g}$.

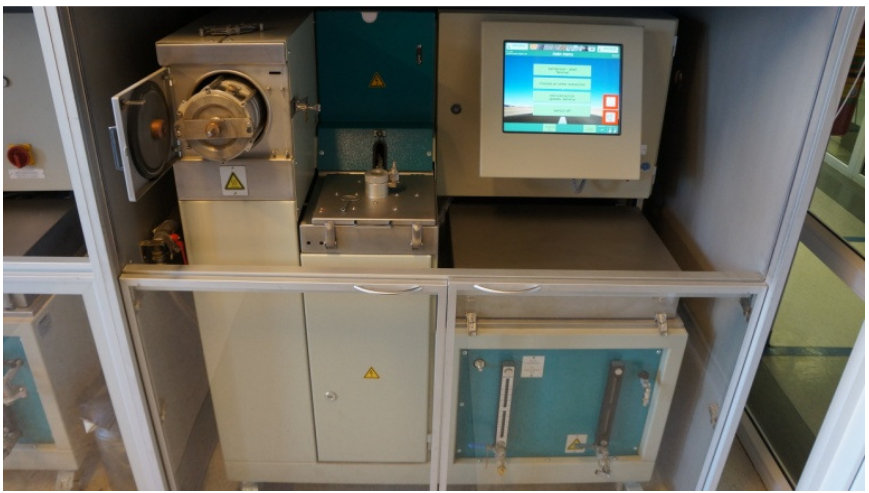

a)

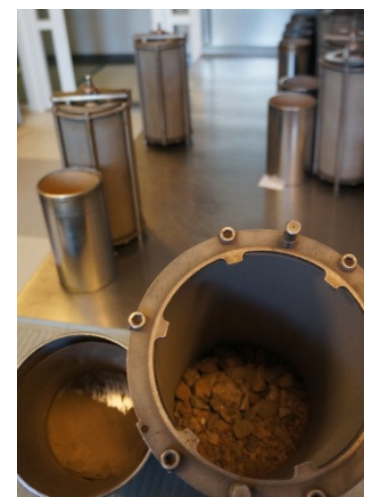

b)

3.4 pav. Laboratorinè ịranga bituminio rišiklio kiekiui ir asfaltinio mišinio granuliometrinei sudèčiai nustatyti

Fig. 3.4. Laboratory equipment for the determination of bitumen binder content and grading of asphalt concrete mixture

Atliekant asfaltinio mišinio mineralinių medžiagų granuliometrinès sudèties bandymą granuliometrinè sudètis nustatoma sijojant ir sveriant. Mineralinès medžiagos tyrimas atliekamas ekstrahavus bitumini rišiklį. Centrifugoje likę mineralinès medžiagos grūdeliai ir mineraliniai milteliai 3.4 paveikslas (b) sijojami ir plaunami per reikiamo akelių dydžio sietus $(\mathrm{mm})$. Mūsų tyrimui buvo atrinkta mineralinès medžiagos masès dalis, likusi ant $2 \mathrm{~mm}$ ir prabyrejusi per $0,09 \mathrm{~mm}$ akelių dydžio sietus. 
Asfaltinio mišinio turštymètumo rodiklio bandymui ị laboratoriją pristatytas èminys padalijamas (ketvirčiuojamas) i dvi dalis. Viena èminio dalis (nuo $1050 \mathrm{~g}$ iki $1400 \mathrm{~g})$ pakaitinama iki $140-150{ }^{\circ} \mathrm{C}$ temperatūros, supilama i pašildytą $\left(<+150^{\circ} \mathrm{C}\right)$ formą, ir specialiu Maršalo tankinimo prietaisu (3.5 pav., a) sutankinamas reikiamo aukščio $(60,5-66,5 \mathrm{~mm})$ bandinys (pagal LST EN 12697-30).

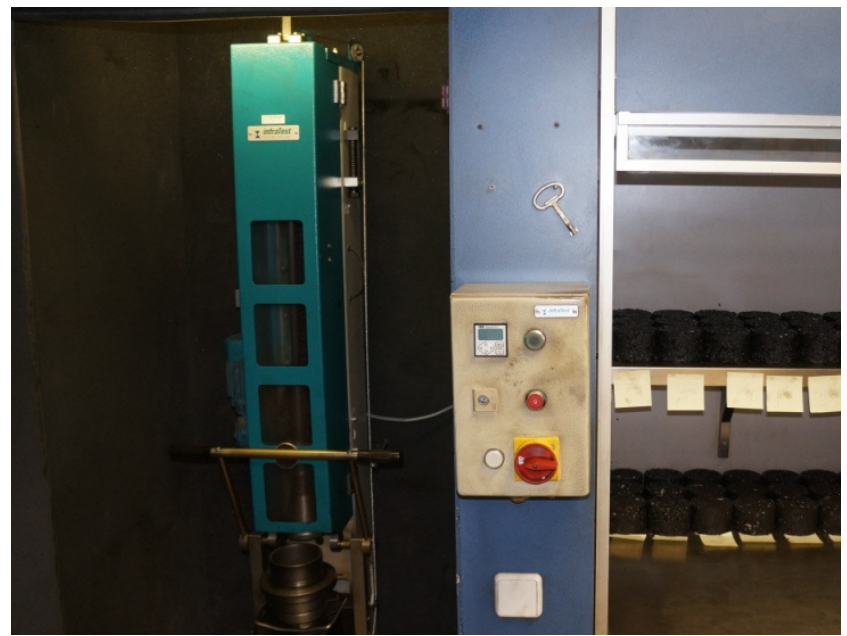

a)

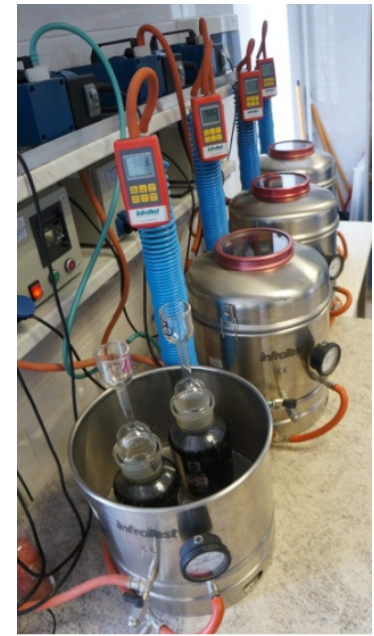

b)

3.5 pav. Laboratorinè ịranga asfaltbetonio bandiniams suformuoti ir tariamajam bei didžiausiam tankiui nustatyti

Fig. 3.5. Laboratory equipment for forming asphalt concrete samples and defining the expected and maximum density

Išmatavus gauto bandinio aukšti, skersmenį ir ji pasvèrus, gaunamas tariamasis AB mišinio tankis $\rho_{\mathrm{b}}$ (LST EN 12697-6). Antra padalyto AB èminio dalis susmulkinama rankomis, nepažeidžiant mišinyje esančių grūdelių. Paruoštas bandinys supilamas i piknometą su vandeniu ir įdedamas i vakuumatorių (3.5 pav., b). Vakuumuojant bandini, pašalinamas visas asfaltiniame mišinyje esantis oras. Pasvèrus bandini (po vakuumavimo), apskaičiuojamas didžiausias asfaltinio mišinio tankis $\rho_{\mathrm{m}}$ (LST EN 12697-5). Sutankintų AB bandinių oro tuštymių skaičius apskaičiuojamas pagal 3.2 formulę (LST EN 12697-8):

$$
V_{m}=\frac{\rho_{m}-\rho_{b}}{\rho_{m}} \times 100 \%,
$$


čia $V_{\mathrm{m}}-$ mišinio akytumas, $\% ; \rho_{\mathrm{m}}-$ didžiausias mišinio tankis, $\mathrm{Mg} / \mathrm{m}^{3} ; \rho_{\mathrm{b}}-$ tariamasis mišinio tankis, $\mathrm{Mg} / \mathrm{m}^{3}$.

Vykdant paklotos kelio $\mathrm{AB}$ dangos kokybès kontrolę, parenkamos vietos èminiams (kernams) iš dangos paimti ir nustatomas èminių skaičius, kuris reikalingas tolesniems asfaltbetonio tyrimams atlikti. Asfaltbetonio kernų gręžimo vietos objekte parenkamos vadovaujantis atsitiktinių skaičių teorija, tačiau ši teorija gali būti koreguojama taip, kad atstumai tarp kernų èmimo vietų būtų apytikriai vienodi, o atstumai nuo kelio ašies būtų skirtingi ir apimtų visą gręžiamo ruožo ploti. Tipinè kernų èmimo schema pavaizduota 3.6 paveiksle (a).

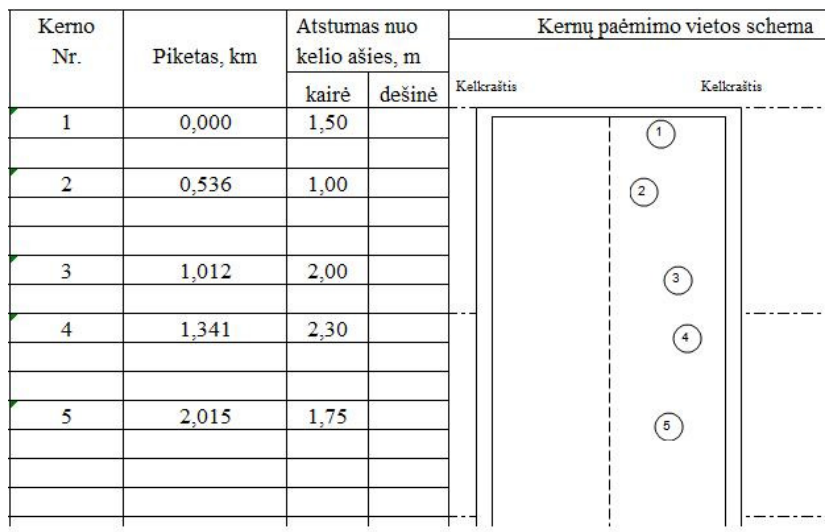

a)

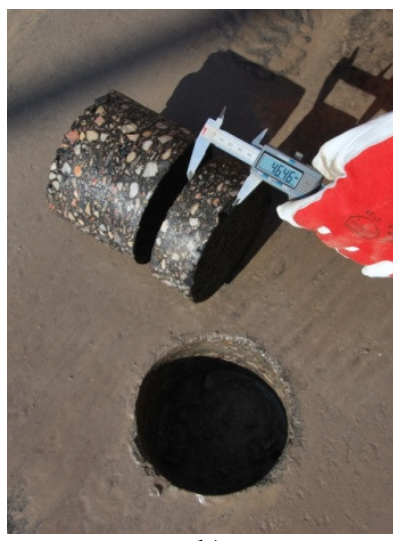

b)

3.6 pav. Asfaltbetonio kernų iš kelio dangos paèmimo vietų tipinè schema (a) ir $\mathrm{AB}$ dangos sluoksnių storio matavimas (b)

Fig. 3.6. Principle scheme for the taking of asphalt concrete core from the pavement (a) and the measurement of asphalt concrete layer thickness (b)

Tokiu būdu buvo atlikti tyrimai pirmajame ir antrajame tyrimų ruožuose. Išgręžus èminius (kernus), slankmačiu, išmatuoti jų aukščiai ir nustatytas faktinis atskiro AB dangos sluoksnio storis pagal LST EN 12697-29 (3.6 pav., b). $\mathrm{AB}$ mišinio sutankinimo laipsnis $k$ apskaičiuojamas žinant iš $\mathrm{AB}$ dangos paimto éminio (kerno) tūrini tanki $\rho_{\mathrm{b}, \mathrm{c}}$ ir iš paimtų kernų $\mathrm{AB}$ bandinio, pagaminto pagal LST EN 12697-30, tūrinį tankị $\rho_{\mathrm{b}, \mathrm{i}}$ pagal 3.3 formulę:

$$
\mathrm{k}=\frac{\rho_{\mathrm{b}, \mathrm{c}}}{\rho_{\mathrm{b}, \mathrm{i}}} \cdot 100 \%,
$$

čia $\rho_{\mathrm{b}, \mathrm{c}}-$ tariamasis $\mathrm{AB}$ èminių (kernų) tankis, $\mathrm{Mg} / \mathrm{m}^{3} ; \rho_{\mathrm{b}, \mathrm{i}}-$ tariamasis $\mathrm{AB}$ tankis, $\mathrm{Mg} / \mathrm{m}^{3}$. 
Atliktų tyrimų apimtis pateikta 3.2 lentelèje.

3.2 lentelè. Eksperimentinių tyrimų apimtis

Table 3.2. The total amount of experimental research

\begin{tabular}{|c|c|c|}
\hline \multirow{3}{*}{ Rodiklis } & \multicolumn{2}{|c|}{ Tyrimų ruožai } \\
\hline & pirmasis & antrasis \\
\hline & \multicolumn{2}{|c|}{ bandymų (matavimų) skaičius, vnt. } \\
\hline Dangos lygumas $Y_{\mathrm{IRI}}$ & 643 & 226 \\
\hline Dangos vėžètumas $H_{\mathrm{V}}$ & 643 & 226 \\
\hline Dangos suirties mastas $D_{\mathrm{D}}$ & 643 & 226 \\
\hline Ėminių èmimo vieta, $\mathrm{Pk}$ & 21 & 18 \\
\hline Bituminio rišiklio $B$ kiekis, masès $\%$ & 63 & 54 \\
\hline $\begin{array}{l}\text { AB mišinio granuliometrinė sudètis, ( } S K ; M M \\
\text { kiekis, masès \%) }\end{array}$ & 63 & 54 \\
\hline $\mathrm{AB}$ mišinio tariamasis tankis $\rho_{\mathrm{b}}$ & 63 & 54 \\
\hline $\mathrm{AB}$ mišinio didžiausias tankis $\rho_{\mathrm{m}}$ & 63 & 54 \\
\hline AB kenų (èminių) èmimas (gręžimas) - èminiai & 84 & 72 \\
\hline AB dangos sluoksnio storis $h$ & 252 & 276 \\
\hline AB kerno tariamasis tankis $\rho_{\mathrm{b}, \mathrm{c}}$ & 63 & 54 \\
\hline $\mathrm{AB}$ bandinio formavimas - bandiniai & 252 & 276 \\
\hline AB suformuoto bandinio tariamasis tankis $\rho_{\mathrm{b}, \mathrm{i}}$ & 63 & 54 \\
\hline
\end{tabular}

3.2 lentelèje pateiktas pirmojo ir antrojo kelio ruožų atliktų dangos eksploatacinių rodiklių matavimų kelyje ir tyrimų laboratorijoje skaičius.

\subsubsection{Kelio dangos tyrimų metodai}

Kompleksiniai kelio dangos būklès tyrimai buvo atlikti naudojant mobiliają kelių dangos būklès rodiklių matavimo ịrangą RST-28 (3.7 pav., a, b). Sis irenginys vienu metu matuoja skirtingus kelio dangos parametrus (kelio dangos lygumą, makrotekstūrą, véžių gylị, plyšių tinklą, skersinius ir išilginius nuolydžius, kreivių plane horizontaliuosius spindulius), mūsų eksperimentui atlikti buvo išmatuoti kelio dangos eksploataciniai rodikliai:

- kelio dangos lygumas $Y_{\mathrm{IRI}}$

- kelio dangos véžių gylis $H_{\mathrm{V}}$;

- kelio dangos plyšių tinklas $D_{\mathrm{D}}$.

Kelio dangos išilginis lygumas IRI matuojamas panaudojus du akcelerometrus (skiriamoji geba $-5 \mu \mathrm{g}$ ), skirtus automobilio svyravimams nufiltruoti, matavimų tikslumas $- \pm 0,2 \%$. 


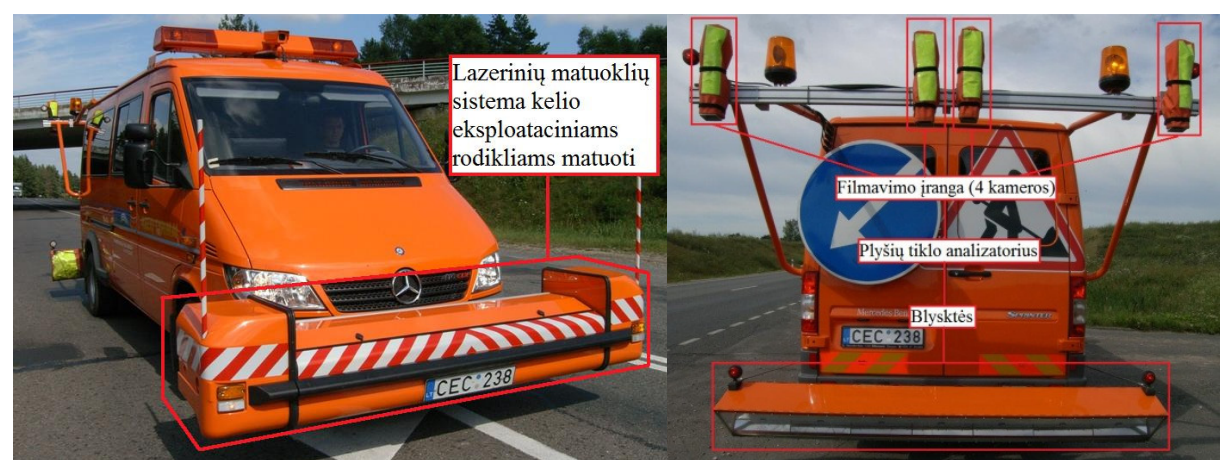

a)

b)

3.7 pav. Mobilioji kelių dangos būklès rodiklių matavimo ịranga RST-28

Fig. 3.7. Mobile road surface tester RST-28

Provèžų gyliai matuojami kas $10 \mathrm{~cm}$. Apskaičiuoti ir pateikti kiekvieno $20 \mathrm{~m}$ ilgio kelio ruožo vidutinis kairiosios ir dešiniosios vèžès gyliai yra tikslūs ir patikimi, kad būtų galima atlikti kelio dangos būklès analizę. Skaičiavimuose analizuojami didesni, t. y. dešiniosios provéžos gylio, rezultatai. Kelių dangos vèžès matavimo tipinè schema pateikta 3.8 paveiksle. Provėžu gylį fiksuoja ant priekinès automobilio dalies (sijos), sumontuota 19 lazerinių matuoklių sistema (3.7 pav., a).

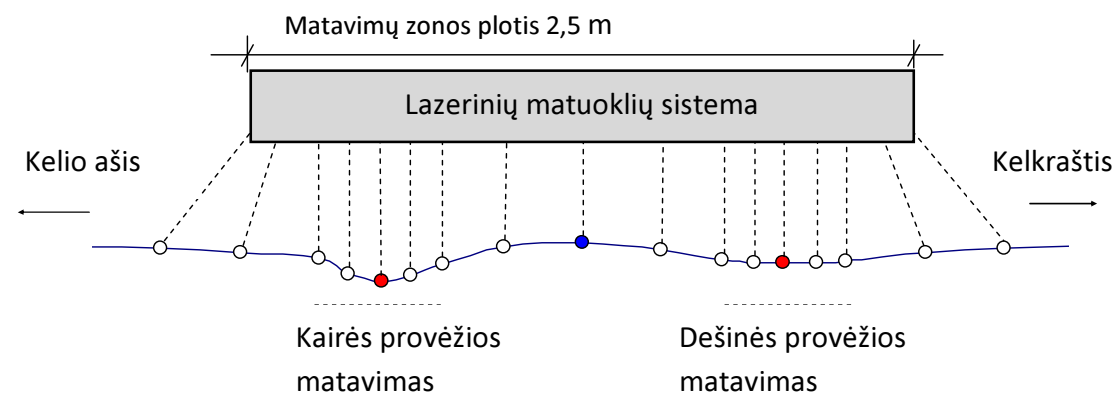

3.8 pav. Kelių dangos vėžès matavimo tipinè schema, naudojant ịrangą RST -28 Fig. 3.8. Principle scheme for measuring pavement rut with the use of the tester RST-28

Kelių dangos būklę (skersinius, išilginius plyšius, plyšių tinklą ir kt.) fiksuoja galinèje automobilio dalyje irengtos keturios vaizdo kameros (3.7 pav., b). Kelių danga filmuojama vieno metro ruožais, o gauti duomenys superkompiuteriu perkeliami i skaitmeninį formatą. Turima medžiaga superkompiuteriui ir duomenų apdorojimo programa filtruojama, įvertinant kelio 
dangos tekstūrą. Filtravimo rezultatas - plyšių kontūrų išryškinimas Pagal gautus plyšių kontūrus programa apskaičiuoja plyšių dengiamą plotą (suirties mastą $D_{\mathrm{D}}$.), išreikštą suirusios dangos ploto \% (3.9 pav.).
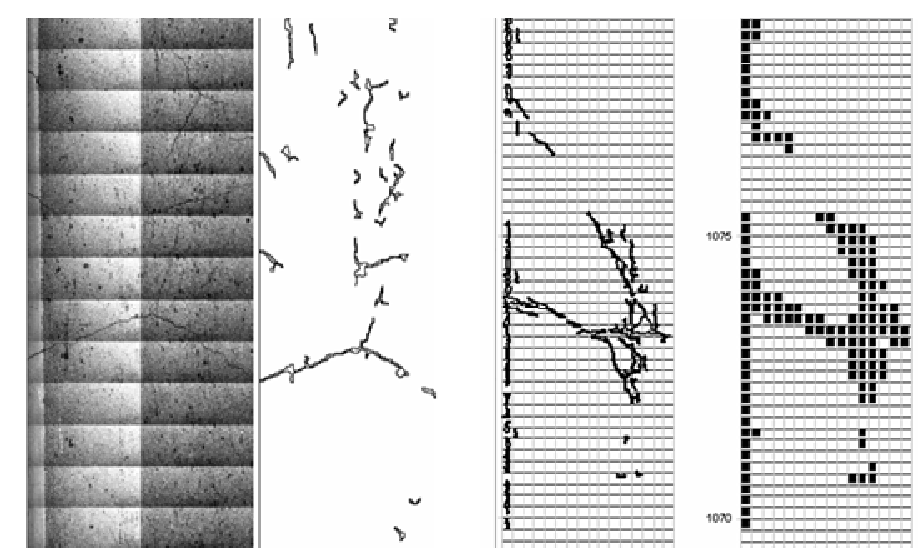

3.9 pav. Plyšių ploto išryškinimas, naudojant ịrangą RST-28

Fig. 3.9. Measurement of the area of cracks with the use of the tester RST-28

Naudojant mobiliają kelių dangos tyrimų laboratoriją RST -28, KD eksploataciniai rodikliai (kelio dangos išilginis lygumas, vėžès gylis ir suirties mastas) išmatuoti tiksliai tose pačiose vietose ir tuo pačiu metu. Gautų rezultatų patikimumas ir gausa leidžia atlikti kelių dangos būklès vertinimo analizę.

\subsubsection{Tyrimų duomenų apdorojimo metodai}

Bandymu rezultatai apdoroti „Maple 10 Academic edition“ programa. Šia programa, buvo apskaičiuojami statistiniai rodikliai: $n$-imtis, $x_{\min }$ - mažiausioji imties vertè, $x_{\text {maks }}-$ didžiausioji imties verte, $\bar{x}$ - imties vidurkis, $s$-standartinis nuokrypis, $s^{2}-$ dispersija, $g_{1}-$ asimetrijos koeficientas, $g_{2}-$ eksceso koeficientas. Taip pat nustatyti skirstiniai jų koreliacijos koeficientas $R$, determinacijos koeficientas $R^{2}$ ir regresijos lygtys. Sugrupavus analizuojamus rodiklius (programa „STATISTIKA 7“), buvo sudaryti: tiriamujų rodikliu priklausomybès nuo ịvesties parametrų (kintamujų) matematiniai modeliai; koreliacinè matrica; apskaičiuota tiesinès regresijos lygtis, (kaip pavaizduota 2.8 lygtimi). Gautas matematinis modelis pagrịstas tiesinès priklausomybès tarp kintamųų ir nagrinejjamų rodiklių $\left(Y_{\mathrm{IRI}}\right.$ ir $H_{\mathrm{V}}$ ) buvimu. Statistinio skaičiavimo tikslas - apskaičiuoti KDK sluoksnių ir jų medžiagų kokybės rodiklių tarpusavio regresinius ryšius. 
Gautos dangos būklès prognozès lygties kintamieji (rodikliai), naudojant skirstinių analitinę programą „EasyFit 5.5 professional“, išanalizuoti ir kiekvienai kintamujų imčiai nustatytas artimiausias skirstinys. Pagal gautų skirstiniu funkcijas atskiriems kintamiesiems (rodikliams) Monte Karlo metodu sugeneruota 1000 atsitiktinių verčių.

Naudojantis daugiaplatforme „MathWorks“ programine įranga „MATLAB“, atlikta kintamųų (rodiklių) modeliavimo duomenų neapibrèžties tikimybinè analizè. Taikant Monte Karlo metodą ir jautrumo indeksais pasirinkus standartizuotus regresijos koeficientus (SRK), buvo atlikta modeliavimo rezultatu jautrumo analizè kiekvienai sudarytai tiesinei regresijos lygčiai.

Norint pasiekti rezultatai būtu aiškesni, kiekvieno poskyrio pradžioje pateikti santrumpų paaiškinimai ir apibendrinti kintamujų analiziniai skaičiavimų rezultatai. Visi pirminiai duomenys, naudoti statistiniam rezultatų apdorojimui, pateikti prieduose.

Sudarius formulę, buvo išspręstas lygties neapibrèžties uždavinys ir apskaičiuotas atskiro lygties rodiklio jautrumas. Rezultato neapibrèžties ir jautrumo analizė atlikta tikimybiniu būdu. Parametrai laikyti atsitiktiniais dydžiais ir jų igyjamos vertès aprašytos tikimybiniais skirtinių désniais (pateikta prieduose). Pavyzdžiui, pritaikius Monte Karlo metodą, atsitiktiniu būdu parinktos analizuojamų parametrų vertès ir atliktas modeliavimas, o neapibrèžtumo ir jautrumo analizè atlikta naudojant sugeneruotų parametrų verčių rinkinius ir gautus modeliavimo rezultatus.

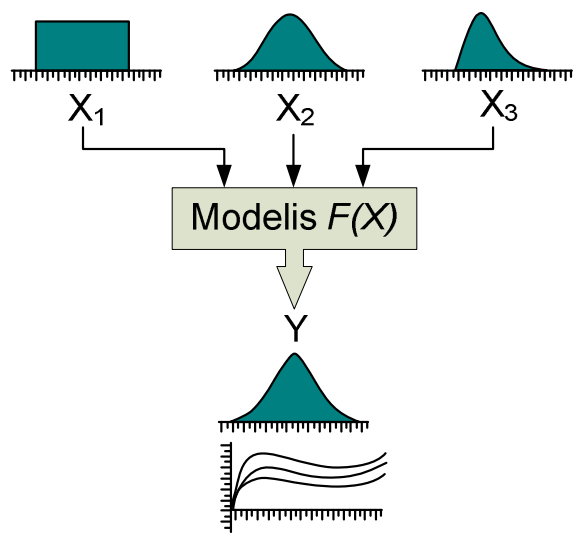

3.10 pav. Imties generavimo (Monte Karlo) metodu pagrịsta neapibrěžties analizė

Fig. 3.10. Uncertainty analysis based on sample generation (Monte Carlo) method 
Svarbiausieji atliktos tikimybinès rezultatų neapibrèžties analizès žingsniai šie:

1. Išanalizuoti gauto modelio rezultatai (vidurkis, vidurkio pasikliauties intervalas, kriterijaus viršijimo tikimybè), parinkti pagrindiniai įvesties parametrai ( jie buvo pasirenkami įvairesni).

2. Parinktiems ivesties parametrams apibrèžti tikimybinio skirstinio dèsniai.

3. Sugeneruota ivvesties parametrų verčių aibè, ivvertinant jų skirstinių dèsnius.

4. Kiekvienam parametrų verčių rinkiniui atlikti skaitiniai vertinimai ir gauti modelio rezultato verčių rinkiniai.

5. Rezultatų neapibrėžtumas pateiktas skaitine išraiška (vidurkis, standartinis nuokrypis (dispersija), kvantiliai, skirstinio charakteristikos) ir grafinė išraiška (kiekvieno realizuoto rezultato priklausomybė nuo laiko, kvantiliai, tikimybès tankio funkcijos (PDF), kumuliacinès tikimybės funkcijos (CDF)).

Atlikus rezultato neapibrèžties analizę, neapsiribota tik jo galimų kitėjimo ribų ar tikimybės, kuriai esant rezultatas viršys (ar neviršys) nustatytą ribinę vertę, ivvertinimu. Siekiant sistemos optimizavimo, ivertinti tie KDK rodikliai, kurie turi daugiausiai itakos KD eksploataciniams rodikliams. Svarbiausias rezultatų jautrumo analizès tikslas: nustatyti, kuris iš ịvesties parametrų turi didžiausią ịtaką KDK būklès prognozavimo matematinio modelio rezultatui ir pagal šią ịtaką ivvertinti KDK rodiklių parametrų svarbą.

Skaitinès jautrumo analizès pirmieji žingsniai buvo šie: įvesties parametrų skirstinių parinkimas, parametro verčių generavimas (1000 verčių), modeliavimas ir modelio rezultato verčių rinkinio sudarymas. Tuomet atlikta pati jautrumo analizè, taikant Monte Karlo metodą. Kadangi dalis žingsnių yra analogiški žingsniams, atliekamiems neapibrèžtumo analizės metu, jautrumo analizei panaudotos tos pačios ịvesties parametrų aibès ir gauti rezultatai. Pagal jautrumo analizės rezultatus galima nustatyti, kurių modelio parametrų tikslesnis ivvertinimas leistų gerokai sumažinti rezultato neapibréžtumą ir kurių parametrų tolesnis tikslinimas nèra prasmingas (Kopustinskas et. al. 2007).

Modelio skaičiavimo (realizacijų) skaičius, reikalingas patikimam jautrumo indeksu ivertinimui, priklauso nuo parametrų skaičiaus ir imties sudarymo metodo.

Jautrumo analizès metodai skirstomi i globalios ir lokalios analizès metodus. Taikant globalios jautrumo analizès metodus, vertinama visų analizuojamų kintamųų neapibrèžties ịtaka rezultato neapibrėžčiai, todèl (šiuo atveju) tenka atlikti daug modelio skaičiavimų.

Rezultatų neapibrèžties priklausomybei nuo parametrų neapibrèžties nusakyti buvo nustatytas Pirsono koreliacijos koeficientas. Parametro $x_{\mathrm{i}}$ 
koreliacijos (Pirsono) koeficientas nusako tiesinę priklausomybę tarp parametro ir rezultato ir yra apskaičiuojamas (Kopustinskas et. al. 2007):

$$
P K K=r(x, y)=\frac{\sum_{i=1}^{n}\left(x_{i}-\bar{x}\right)\left(y_{i}-\bar{y}\right)}{\sqrt{\sum_{i=1}^{n}\left(x_{i}-\bar{x}\right)^{2} \sum_{i=1}^{n}\left(y_{i}-\bar{y}\right)^{2}}}=\frac{n \sum_{i=1}^{n} x_{i} y_{i}-\sum_{i=1}^{n} x_{i} \sum_{i=1}^{n} y_{i}}{\sqrt{\left(n \sum_{i=1}^{n} x_{i}^{2}-\left(\sum_{i=1}^{n} x_{i}\right)^{2}\right) \cdot\left(n \sum_{i=1}^{n} y_{i}^{2}-\left(\sum_{i=1}^{n} y_{i}\right)^{2}\right)}} \cdot
$$

Ryšio tarp kintamujų glaudumo matui naudotas koreliacijos determinacijos koeficientas $R^{2}$. Kuo determinacijos koeficiento verte artimesnè vienetui, tuo parametro $x_{i}$ ịtaka rezultato neapibrèžčiai būna didesnè.

Atliekant regresinę analizę, rezultato ir ịvesties parametrų priklausomybė, kurią bendruoju atveju galima apibrěžti kaip $F\left(x_{1}, x_{2}, \ldots x_{N}\right)$, aprašoma tiesinès regresijos lygtimi (3.5 lygtis), o rezultato jautrumą vieno ar kito parametro pokyčiui rodo regresijos lygties koeficientai:

$$
y=F\left(x_{1}, x_{2}, \ldots x_{N}\right)=b_{0}+b_{1} x_{1}+b_{2} x_{2}+b_{3} x_{3}+\ldots+b_{N} x_{N},
$$

čia $x_{i}$ - regresijos lygties kintamieji, $i=0 \ldots \mathrm{n} ; b_{i}$ - regresijos lygties koeficientai, $i=0 . . . n$.

Regresijos lygties koeficientai $b_{i}$ apskaičiuoti mažiausių kvadratų metodu, tačiau dažniausiai jie negali būti jautrumo indeksais, nes skiriasi parametru matavimo skalès. Parametrų matavimo vienetai normuojami standartizuojant kiekvieną parametrą ir modelio rezultatą (Kopustinskas et. al. 2007):

$$
\begin{gathered}
\hat{x}_{i, k}=\frac{x_{i, k}-E x_{i}}{\sigma x_{i}} ; i=1,2, \ldots, n ; k=1,2, \ldots, m, \\
\hat{y}_{k}=\frac{y_{k}-E y}{\mathscr{Y}},
\end{gathered}
$$

čia $E x_{i}$ - parametro $x_{i}$ vidurkis; $\sigma x_{i}$ - parametro $x_{i}$ standartinis nuokrypis; Ey - rezultato vidurkis; $\sigma$ - rezultato standartinis nuokrypis; $m$ - parametrų atsitiktinès imties dydis; $n$ - parametrų skaičius.

Sudarius daugialypès regresijos lygti, standartizuotiems duomenims lygties koeficientai $\beta_{i}$ (3.8 lygtis), vadinami standartizuotais regresijos koeficientais (SRK) buvo panaudoti kaip parametru jautrumo indeksai:

$$
\hat{y}=\alpha+\beta_{1} \widehat{x}_{1}+\beta_{2} \widehat{x}_{2}+\ldots+\beta_{n} \widehat{x}_{n} .
$$

Būtina regresinès analizès metodo taikymo sąlyga - tiesinè rezultato priklausomybė nuo parametrų, monotoniškumas, o metodo tinkamumas 
ivertinamas pagal determinacijos koeficiento $R^{2}$ vertę, kuris apskaičiuojamas pagal šia formule:

$$
R^{2}=\frac{S S_{R}}{S S_{p}}
$$

čia $S S_{p}$ - bendroji nuokrypių kvadratu suma; $S S_{p}=\sum_{i=1}^{n}\left(y_{i}-\bar{y}\right)^{2}$, apibūdinanti y verčių sklaidą apie vidurki $\bar{y}, S S_{R}$ - regresinè nuokrypių kvadratų suma, $S S_{R}=\sum_{i=1}^{n}\left(\hat{y}_{i}-\bar{y}\right)^{2}$, apibūdinanti $y$ verčių, gautų iš regresijos lygties su nustatytais regresijos koeficientais, sklaidos apie vidurki dali.

Koeficiento verte artima vienetui reiškia modelio tiesiškumą ir SRK turi prasmę. Jautrumo analizejje determinacijos koeficiento verté nurodo tą dalị modelio rezultato neapibrèžties, kurią galima paaiškinti analizuojant modelio parametrų neapibrèžti. Likusi nepaaiškinta modelio rezultato neapibrežties dalis yra susijusi su modelio parametrų tarpusavio sąveikos įtaka rezultatui. Ji gali būti analizuojama dispersijos išskaidymo metodais. Praktikoje dažnai reikalaujama, kad tiesinio modelio determinacijos koeficientas būtų ne mažesnis, kaip 0,6-0,7. Esant netiesinei priklausomybei $\left(R^{2}<0,7\right)$, regresinè analizė gali būti atliekama transformuotiems duomenims (rangams), o jautrumo indeksais tampa standartizuoti ranginès regresijos koeficientai (SRRK).

\subsection{Kelių dangos konstrukcijų medžiagụ savybių rodiklių tyrimai}

Atlikus skirtingu gamintojų granito, dolomito ir žvyro skaldos tyrimus, buvo nustatytos plokštumo rodiklio $F I$ ir formos rodiklio $S I$ vertès. Išanalizavus skaldos geometrinių kokybès rodiklių duomenis, gauti šie rezultatai: asfaltbetonio (AB) tinkamumui reikalavimus $F I_{20}$ atitinka $99 \%$, o aukščiausią viršutinę $F I_{15}$ kategoriją atitinka $95 \%$ visų ištirtų granito ir dolomito skaldos bandinių pagal plokščiu grūdelių tyrimų metodą. AB keliamus reikalavimus atitinka $98 \%$ visų skaldos bandinių, ištirtų pagal grūdelių formos rodiklio SI bandymų metodą. Reikalavimų $S I_{15}$ viršutinę leidžiamają ribą viršija $6 \%$ ištirtų skaldos bandinių: $3 \%$ - granito ir 3\% - dolomito skaldos bandinių. Šie tyrimų rezultatai buvo gauti atsitiktiniu būdu iš krūvos statybvieteje ir sandèliavimo vietos atrinkus bandinius. Tai rodo, kad Lietuvos kelių tiesyboje naudojama skalda daugiausia atitinka jai keliamus aukščiausius geometrinius kokybės reikalavimus. Išanalizavus skaldos atsparumo trupinimui rodiklio tyrimų duomenis, gauti šie rezultatai: asfaltinei dangai keliamus reikalavimus $L A_{20}$ 
atitinka $94 \%$ visų ištirtų granito skaldos bandinių pagal $L A$ metodą, $88 \%$ dolomito skaldos bandinių tyrimo duomenų patenka tarp nustatytų reikalavimų $L A_{20}$ ir $L A_{25}$, o $L A_{30}$ reikalavimų ribą viršija $33 \%$ visų žvyro skaldos bandinių tyrimo duomenų. Atsitiktinai atrinktų bandinių iš statybvietès ar sandèliavimo vietos tyrimų rezultatai rodo, kad Lietuvos kelių tiesyboje naudojama granito skalda daugiausia atitinka, o dolomito ir žvyro skalda žvyro skalda daugiausi ne atitinka jai keliamų aukščiausių atsparumo trupinimui reikalavimų. $A B$ dangai keliamus reikalavimus tenkina $81 \%$ visų skaldos bandinių, ištirtų taikant smūgini metodą. Reikalavimų smūginio stiprio $S Z_{18}$ leidžiamają apatinę ribą viršija $19 \%$ ištirtu granito skaldos bandinių, $S Z_{22}$ leidžiamąją apatinę ribą viršija $49 \%$ dolomito skaldos bandinių. Atsitiktinai atrinktų bandinių tyrimų rezultatai rodo, kad Lietuvos kelių tiesyboje naudojama granito skalda, o dolomito skalda tik puse tirtų bandinių atitinka aukščiausius atsparumo trupinimui keliamus reikalavimus. Tai rodo, kad norint dolomito skaldą naudoti asfaltiniams mišiniams, jos stiprio savybes reiktų ištirti išsamiau arba padidinti kontrolinių tyrimų skaičių.

Visų analizuotų uolienų skaldai apskaičiuotos jos savybių rodiklių statistinès charakteristikos pateiktos 3.3 ir 3.4 lentelèse. Analizuojant ištirtas asfaltiniams mišiniams skirtos skaldos savybes, sudarytos atskirų savybių rodiklių statistinių duomenų imtys. Pagal LST EN 1367-1:2007 bandymo metodą atlikta 10 šaldymo ir atšildymo ciklų, kurių metu temperatūra kito nuo $+20{ }^{\circ} \mathrm{C}$ iki $-17.5^{\circ} \mathrm{C}$. Skaldos atsparumo šaldymui ir atšildymui rodiklio $F$ verčių imtis sudaryta iš 123 individualių duomenų $(n=123)$. Šių rodiklio $F$ verčių duomenys pateikti 3.11 paveiksle.

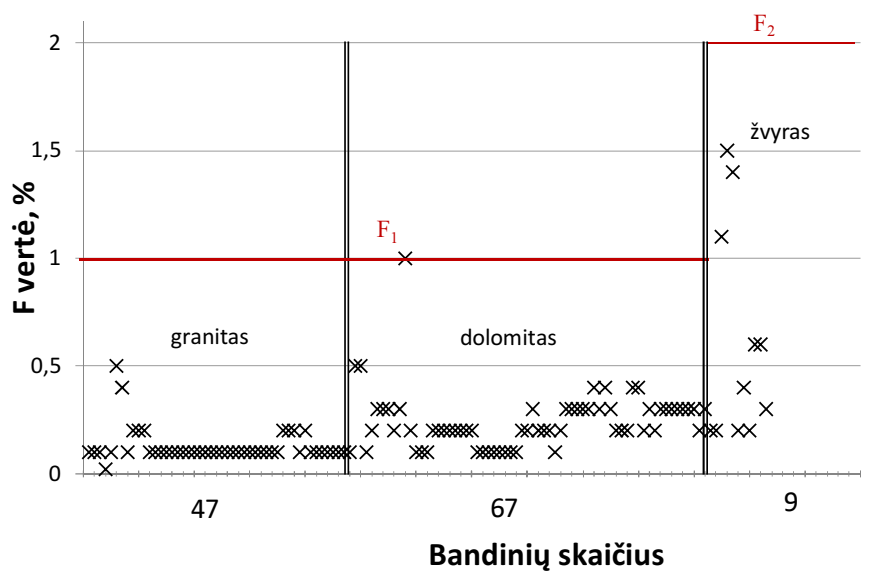

3.11 pav. Skaldos atsparumo šaldymui ir atšildymui rodiklio vertės

Fig. 3.11. The values of the aggregate resistance to freezing and thawing index 
Rodiklio $F$ vertės sugrupuotos pagal uolienų tipus. Analizuojant ir vertinant gautus stambiụų mineralinių medžiagų tyrimų rezultatus, asfaltiniams mišiniams parinktos, pavyzdžiui, $F_{1}$, kai masès nuostoliai $\leq 1 \%$. 3.11 paveiksle pateikti atlikto tyrimo (atsparumo šaldymui ir atšildymui) rezultatai, sugrupuoti pagal uolienos tipus (granitas, dolomitas, žvyras), o leidžiamuosius bandinių išbirų masių nuostolius rodo atitinkamų kategorijų ribos (ribinès $F_{1}$ ir $F_{2}$ vertès), parinktos pagal stambiujų mineralinių medžiagų naudojimą asfaltinès dangos sluoksniuose. Visi ištirtų stambiujų mineralinių medžiagų bandinių atsparumo šaldymui ir atšildymui rezultatai labai aukšti ir $100 \%$ tenkina $\mathrm{AB}$ dangai keliamus $F_{1}$ ir $F_{2}$ reikalavimus. $91 \%$ granito skaldos rezultatų neviršija $1 / 10 F_{1}$ (t. y. 0,1\%), o $80 \%$ dolomito skaldos rezultatu neviršija $1 / 5 F_{1}$ (t. y. $0,2 \%$ ). Visi žvyro skaldos tyrimų rezultatai patenka tarp $F_{1}$ ir $F_{2}$ ribų.

Gautos mažos statistinių rodiklių vertes rodo, kad atsparumo pakartotiniam šaldymui ir atšildymui bandymų, vertinant jos tinkamumą asfaltiniams mišiniams, nepakanka. Dolomito ir granito skaldos rodiklio $F$ verčių aritmetiniai vidurkiai skiriasi nedaug. Žvyro skaldos bandinių tyrimų duomenu vidutinè vertė yra penkis kartus didesne už granito ir tris kartus už dolomito aritmetinius vidurkius. Tai rodo, kad žvyro skalda atitinkamai mažiau kartų atspari aplinkos temperatūros poveikiui nei granito ir dolomito skalda.

3.12 paveiksle pateiktos skaldos atsparumo trupinimui rodiklio $L A$ vertès. Ši imtis sudaryta iš 59 individualių duomenų $(n=59)$.

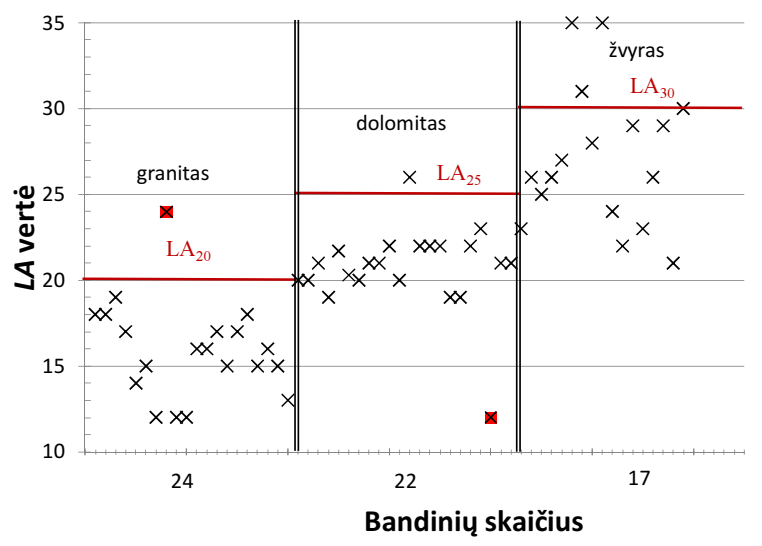

3.12 pav. Skaldos atsparumo trupinimui rodiklio vertes

Fig. 3.12. The values of the aggregate resistance to fragmentation index

3.12 paveiksle rodiklio $L A$ vertès sugrupuotos pagal uolienų tipus. Užpildyti taškai parodo atliekant tolimesnius statistinius skaičiavimus atmestas (dèl akivaizdaus išsiskyrimo) vertes. Tyrimų rezultatai įvertinti pagal atitiktị 
kategorijoms. Atitinkamai koeficientai žymimi $L A_{20}, L A_{25}, L A_{30}$, kur indeksai 20 , 25,30 rodo bandinio nuostolius masès procentais po bandymo, t. y. pavyzdžiui $L A_{20}$, kai masès nuostoliai $\leqslant 20$. AB dangos reikalavimus $L A_{20}$ atitinka $94 \%$ visų ištirtų stambiụjų mineralinių medžiagų bandinių pagal $L A$ metodą. $88 \%$ dolomito skaldos bandymo duomenu patenka tarp $L A_{20}$ ir $L A_{25}$ ribų. $L A_{30}$ reikalavimų ribą viršija 33 \% visų žvyro skaldos bandinių.

Skaldos atsparumo smūginiam trupiui rodiklio $S Z$ vertès pateiktos 3.13 paveiksle. Šios vertès sugrupuotos pagal uolienų tipus. Atsparumo smūginiam trupiui rodiklio $S Z$ imti sudaro 238 individualūs duomenys $(n=238)$. Užpildyti taškai parodo tolimesniuose statistiniuose skaičiavimuose atmestas (dèl išsiskyrimo) rodiklio $S Z$ vertes.

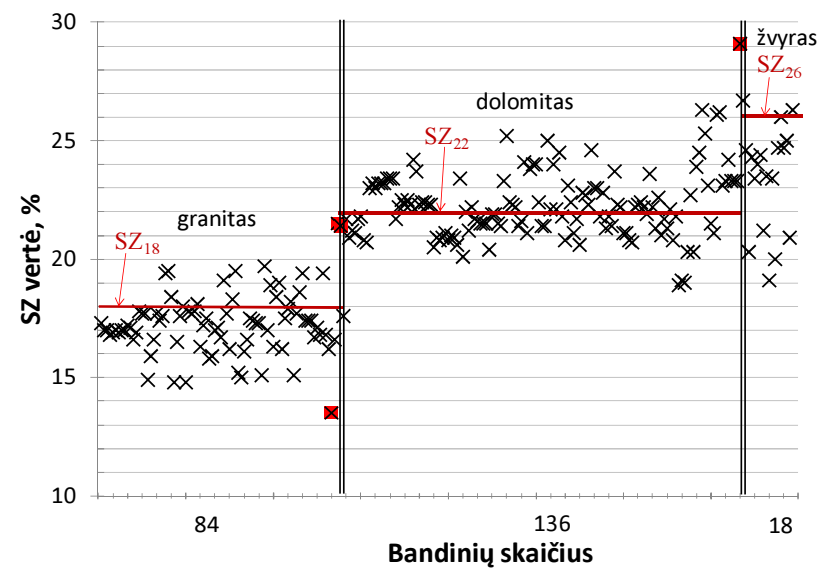

3.13 pav. Skaldos atsparumo smūginiam trupiui rodiklio vertès

Fig 3.13. The values of aggregate impact resistance

Skaldos atsparumo trupinimui rodikliai $S Z_{18}, S Z_{22}, S Z_{26}, S Z_{32}$ ir $S Z_{35}$, kur indeksai $18,22,26,32$ arba 35 rodo išbirų masių nuostolius procentais per penkis kontrolinius sietus, pavyzdžiui, $S Z_{18}$, kai masès nuostoliai $\leq 18 \%$. Atlikta ištirtos skaldos mechaninių savybių rodiklių verčių statistinè analizė (3.3 ir 3.4 lentelès). Visų trijų tirtų uolienų skaldos atsparumo kartotiniam šaldymui ir atšildymui verčių sklaida buvo nedidelè: pataisytas standartinis nuokrypis kito nuo $0,08 \%$ iki $0,5 \%$. Granito skaldos tyrimo duomenu standartinis nuokrypis gautas itin nedidelis. Tai rodo skaldos atsparumo aplinkos poveikiui nedidelę bandymo duomenu sklaidą. Granito ir dolomito skaldos tyrimų duomenu vidurkiai neviršija atitinkamai $13 \%$ ir $25 \%$ aukščiausios $F_{1}$ kategorijos vertès $\left(F_{1}\right.$ atitinka masès nuostolius iki $1 \%$ ). Pagal smūgini metodą. $S Z_{18}$ ribą viršija $27 \%$ tirtų granito skaldos bandinių, $S Z_{22}$ ribą viršija $36 \%$ dolomito skaldos 
bandinių, o $S Z_{26}$ ribą viršija $23 \%$ žvyro skaldos bandinių. Dèl mažo verčių ìvairumo, t. y. dèl verčių mažos sklaidos arba dèl nepakankamo tyrimų duomenų skaičiaus, atsparumo poliruojamumui ir Devalio rodikliams tolimesni skaičiavimai nebuvo atliekami.

Atlikta skaldos sausujų grūdelių tankio (SGT) rodiklio $\rho_{\text {rd }}$ duomenu statistinè analize (3.5 lentelè). Didžiausią SGT rodiklio $\rho_{\text {rd }}$ verčių aritmetinị vidurkį gavome dolomito skaldai, o mažiausią - žvyro skaldai. Tirtų uolienų skaldos SGT rodiklio $\rho_{r d}$ verčių amplitudès kitimas yra siaurų ribų - 0,05-0,15 $\mathrm{Mg} / \mathrm{m}^{3}$. Tai rodo nedidelę šio rodiklio verčių sklaidą. Visų trijų uolienų skaldos SGT rodiklio $\rho_{r d}$ verčių standartiniai nuokrypiai yra artimi - tai rodo panašią tirto rodiklio verčiu variaciją. Granito bei dolomito skaldos rodiklių $L A$ ir $S Z$ aritmetinių vidurkių vertès yra artimos. Žvyro skaldos tirtų savybių rodiklių standartinių nuokrypių vertès gautos didžiausios. Tai rodo šios skaldos tirtų fizinių savybių rodiklių verčių didžiausią variaciją.

3.3 lentelè. Granito ir dolomito skaldos mechaninių rodiklių verčių suvestinè

Table 3.3. Summary values of the mechanical indices of crushed granite and dolomite

\begin{tabular}{|c|c|c|c|c|c|c|c|c|c|c|}
\hline \multirow{4}{*}{$\begin{array}{l}\text { Statistinis } \\
\text { rodiklis }\end{array}$} & \multicolumn{10}{|c|}{ Uoliena } \\
\hline & \multicolumn{5}{|c|}{ granitas } & \multicolumn{5}{|c|}{ dolomitas } \\
\hline & \multicolumn{10}{|c|}{ savybių rodikliai ir jų vertès } \\
\hline & $\mathrm{F}, \%$ & LA & $\mathrm{SZ}, \%$ & PSV & $\mathrm{M}_{\mathrm{DE}}$ & $\mathrm{F}, \%$ & LA & $\mathrm{SZ}, \%$ & PSV & $\mathrm{M}_{\mathrm{DE}}$ \\
\hline$x_{\text {min. }}$ & 0,5 & 19 & 19,7 & 50 & 9 & 1,0 & 26 & 26,3 & 41 & 16 \\
\hline$x_{\text {maks. }}$ & 0,02 & 12 & 14,8 & 53 & 6 & 0,1 & 19 & 18,9 & 47 & 14 \\
\hline Amplitudè & 0,48 & 7 & 4,9 & 3 & 3 & 0,9 & 7 & 7,4 & 6 & 2 \\
\hline$x$ & 0,13 & 15,5 & 17,23 & 51,4 & 6,76 & 0,24 & 21,1 & 22,23 & 44,1 & 15,71 \\
\hline $\begin{array}{c}\text { Standartinis } \\
\text { nuokrypis } \\
\mathrm{s}_{\mathrm{x}}\end{array}$ & 0,08 & 2,11 & 1,13 & 0,89 & 0,75 & 0,13 & 1,55 & 1,36 & 1,58 & 0,55 \\
\hline $\begin{array}{c}\text { Dispersija } \\
\mathrm{s}_{\mathrm{x}}{ }^{2}\end{array}$ & 0,01 & 4,46 & 1,27 & 0,78 & 0,56 & 0,02 & 2,42 & 1,84 & 2,49 & 0,30 \\
\hline $\begin{array}{c}\text { Imties } \\
\text { asimetrijos } \\
\text { koeficientas } \\
g_{1}\end{array}$ & 12,4 & $-0,8$ & 0,1 & $-0,5$ & 2,3 & 14,1 & 3,4 & 0,7 & 0,8 & 3,2 \\
\hline $\begin{array}{c}\text { Imties } \\
\text { eksceso } \\
\text { koeficientas } \\
g_{2}\end{array}$ & 3,3 & $-0,3$ & 0,001 & 0,1 & 1,2 & 2,8 & 1,3 & 0,5 & $-0,01$ & $-1,9$ \\
\hline $\begin{array}{l}\text { Individualių } \\
\text { duomenu } \\
\text { imtis } n\end{array}$ & 47 & 19 & 81 & 15 & 21 & 67 & 21 & 135 & 10 & 21 \\
\hline
\end{tabular}


Visų trijų tirtų uolienų skaldos rodiklio $M_{D E}$ verčių amplitudè yra artima. Tai rodo tirtos rodiklio verčių rezultatų artimą sklaidą visų uolienų skaldai ir galima teigti, kad analizuojamas metodas yra tinkamas tirtos skaldos rodiklio $M_{D E}$ vertèms nustatyti.

3.4 lentelè. Žvyro skaldos mechaninių rodiklių verčių suvestinè

Table 3.4. Summary values of the mechanical indices of crushed gravel

\begin{tabular}{|c|c|c|c|c|}
\hline \multirow{2}{*}{ Statistinis rodiklis } & \multicolumn{4}{|c|}{ Žvyro savybių rodikliai ir jų vertės } \\
\hline & $F$ & $L A$ & $S Z$ & $M_{D E}$ \\
\hline 1 & 2 & 3 & 4 & 5 \\
\hline Imties mažiausioji verte ${ }_{\text {min. }}$ & $1,5 \%$ & 35 & $26,7 \%$ & 20 \\
\hline Imties didžiausioji verte ${ }_{\text {maks. }}$ & $0,2 \%$ & 21 & $19,1 \%$ & 14 \\
\hline Amplitudè & $1,3 \%$ & 14 & $7,6 \%$ & 6 \\
\hline Imties vidurkis $\bar{x}$ & $0,7 \%$ & 27,05 & $23,47 \%$ & 17,8 \\
\hline Standartinis nuokrypis $\mathrm{s}_{\mathrm{x}}$ & $0,478 \%$ & 3,992 & $2,189 \%$ & 1,222 \\
\hline Dispersija $\mathrm{s}_{\mathrm{x}}^{2}$ & $0,23(\%)^{2}$ & 15,94 & $4,79(\%)^{2}$ & 1,49 \\
\hline Imties asimetrijos koeficientas $g_{1}$ & $-1,202$ & $-0,178$ & $-0,655$ & 6,312 \\
\hline Imties eksceso koeficientas $g_{2}$ & 0,708 & 0,587 & $-0,599$ & $-1,769$ \\
\hline Individualių duomenų imtis $\mathrm{n}$ & 9 & 17 & 18 & 15 \\
\hline
\end{tabular}

3.5 lentelè. Skaldos sausujų grūdelių verčių suvestinè

Table 3.5. Summary particles dry density values of the of aggregate

\begin{tabular}{|c|c|c|c|}
\hline \multirow{2}{*}{ Statistinis rodiklis ir jo matavimo vienetas } & \multicolumn{3}{|c|}{ Uoliena } \\
\cline { 2 - 4 } & granitas & dolomitas & žvyras \\
\cline { 2 - 4 } & sausujų grūdelių tankio (SGT) $\rho_{r d}$ vertès \\
\hline Imties mažiausioji vertè $x_{\text {min., }}, \mathrm{Mg} / \mathrm{m}^{3}$ & 2,64 & 2,63 & 2,60 \\
\hline Imties didžiausioji verte $x_{\text {maks. }} \mathrm{Mg} / \mathrm{m}^{3}$ & 2,76 & 2,78 & 2,65 \\
\hline Amplitudè, $\mathrm{Mg} / \mathrm{m}^{3}$ & 0,12 & 0,15 & 0,05 \\
\hline Imties vidurkis $\bar{x}, \mathrm{Mg} / \mathrm{m}^{3}$ & 2,713 & 2,723 & 2,702 \\
\hline Standartinis nuokrypis $\mathrm{s}_{\mathrm{x}}, \mathrm{Mg} / \mathrm{m}^{3}$ & 0,022 & 0,028 & 0,023 \\
\hline Dispersija $\mathrm{s}_{\mathrm{x}}^{2},\left(\mathrm{Mg} / \mathrm{m}^{3}\right)^{2}$ & 0,0005 & 0,0008 & 0,0005 \\
\hline Imties asimetrijos koeficientas $\mathrm{g}_{1}$ & 1,68 & 1,32 & 8,43 \\
\hline Imties eksceso koeficientas $\mathrm{g}_{2}$ & $-0,94$ & $-0,82$ & 2,45 \\
\hline Individualių duomenų imtis $\mathrm{n}$ & 65 & 95 & 16 \\
\hline
\end{tabular}


Dolomito ir žvyro skaldos rodiklio $M_{D E}$ verčių aritmetiniai vidurkiai skiriasi nedaug - tai parodo dolomito, kaip ir žvyro skaldos, nedidelį atsparumą tiriant bandinius šiuo metodu (mechaniškai veikiant uolieną vandenyje). Šių uolienų skaldai atsparumo dèvejimuisi vandenyje savybiu panašumą rodo ir artimi šio rodiklio verčių standartiniai nuokrypiai. Visų trijų tirtų uolienų skaldos šio rodiklio verčių standartiniai nuokrypiai yra nedideli - tai rodo nedidelę duomenų variaciją tiriant bandinius Devalio metodu.

Granito skaldos atsparumo poliruojamumui rodiklio verčiu sklaida ir standartiniai nuokrypiai, lyginant su dolomito skaldos analogiškų verčiu tais pačiais sklaidos rodikliais skiriasi dvigubai - tai rodo daug didesni granito skaldos šio kokybės rodiklio pastovumą.

3.6 lentelè. Granito ir dolomito skaldos mechaninių rodiklių verčių suvestinè

Table 3.6. Summary values of the mechanical indices of crushed granite and dolomite

\begin{tabular}{|c|c|c|c|c|c|c|}
\hline \multirow{4}{*}{ Statistinis rodiklis } & \multicolumn{6}{|c|}{ Uoliena } \\
\hline & \multicolumn{2}{|c|}{ granitas } & \multicolumn{2}{|c|}{ dolomitas } & \multicolumn{2}{|c|}{$\begin{array}{c}\text { Granito, } \\
\text { dolomito ir } \\
\text { žvyro skaldos } \\
\text { mišinys }\end{array}$} \\
\hline & \multicolumn{6}{|c|}{ savybių rodikliai ir jų vertès } \\
\hline & $F I$ & $S I$ & $F I$ & $S I$ & $F I$ & $S I$ \\
\hline Imties mažiausioji vertè $x_{\min }, \%$ & 1 & 1 & 1 & 1 & 1 & 1 \\
\hline Imties didžiausioji vertè $x_{\text {maks. }}, \%$ & 21 & 20 & 18 & 21 & 21 & 27 \\
\hline Amplitudè, \% & 20 & 19 & 17 & 20 & 20 & 26 \\
\hline Imties vidurkis $\bar{x}, \%$ & 9,20 & 8,59 & 7,14 & 8,44 & 7,61 & 8,44 \\
\hline Standartinis nuokrypis $s_{x} \%$ & 5,12 & 3,96 & 3,11 & 3,80 & 3,74 & 3,92 \\
\hline Dispersija $s_{x}^{2},(\%)^{2}$ & 25,23 & 15,66 & 9,69 & 14,41 & 13,96 & 15,34 \\
\hline Imties asimetrijos koeficientas $g_{l}$ & 0,42 & 0,63 & 0,62 & 0,56 & 0,85 & 0,52 \\
\hline Imties eksceso koeficientas $g_{2}$ & 2,36 & 2,94 & 3,52 & 3,04 & 3,82 & 2,91 \\
\hline Individualių duomenų imtis $n$ & 30 & 71 & 102 & 189 & 132 & 273 \\
\hline
\end{tabular}

Analizuoti mineralinių medžiagų fiziniai ir mechaniniai rodikliai skaičiuojant toliau jų tarpusavio ryšius ir analizuoti tinkamumo tyrimų optimizavimo sprendinius. 


\subsection{Konstrukcinių sluoksnių medžiagụ savybių analizè}

Siekiant racionalizuoti kelio dangos konstrukcinių sluoksnių medžiagų tinkamumo tyrimus, buvo atlikta statistinè mineralinių medžiagų rodiklių analizè. Svarbiausias skaičiavimų tikslas - rasti koreliacinius ryšius tarp rodiklių ir išanalizuoti jų statistinius parametrus bei duomenų sklaidos rodiklius.

Koreliacinių priklausomybių tarp ivvairių uolienų skaldos fizinių ir mechaninių rodiklių verčių nustatymas ir hipotezių apie turimų duomenų normaluji pasiskirstymą patikra

Pagal TRA MIN 07:2007 „Automobiliu keliu mineraliniu medžiagu techniniu reikalavimu aprašo " reikalavimus nustatyti skirtingi to paties tipo asfaltinių mišinių leidžiamieji skaldos fiziniai ir mechaniniai rodikliai, todèl reikia patikrinti ir ịvertinti tirtos skaldos skirtingu savybių rodiklių koreliacinès priklausomybès. Analizuojamų rodiklių koreliacinès priklausomybès ịvertintos pagal koreliacijos koeficientu vertes, pateiktas 3.7 ir 3.7 ir lentelèse. Statistinei patikrai atrinkti tik tie bandiniai, kuriems buvo tirti du ar daugiau skaičiavimams naudoti rodikliai. Koreliaciniai ryšiai vertinti pagal 3.8 lentelèje pateiktas vertes.

3.7 lentelè. Koreliacinių priklausomybių tarp granito skaldos fizinių ir mechaninių rodikliu verčių suvestinè

Table 3.7. Summary values of the correlation dependencies between mechanical and physical indices of crushed granite

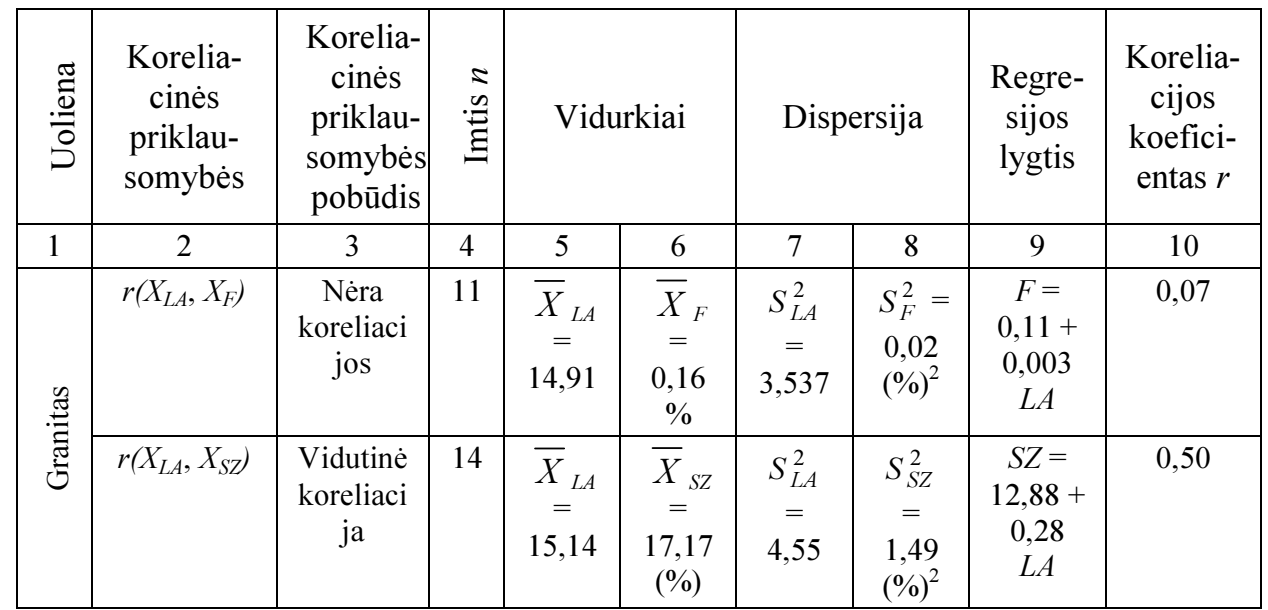


3.7 lentelès pabaiga

The end of Table 3.7.

\begin{tabular}{|c|c|c|c|c|c|c|c|c|c|}
\hline 1 & 2 & 3 & 4 & 5 & 6 & 7 & 8 & 9 & 10 \\
\hline \multirow{5}{*}{ 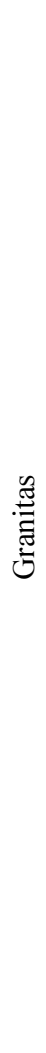 } & $r\left(X_{L A}, X_{\rho_{r d}}\right)$ & $\begin{array}{c}\text { Nèra } \\
\text { koreliaci } \\
\text { jos }\end{array}$ & 11 & $\begin{array}{c}\bar{X}_{L A} \\
= \\
15,50\end{array}$ & $\begin{array}{c}\bar{X}_{\rho_{r d}} \\
=2,72 \\
8 \\
(\mathrm{Mg} / \\
\left.\mathrm{m}^{3}\right)\end{array}$ & $\begin{array}{c}S_{L A}^{2} \\
= \\
9,25\end{array}$ & $\begin{array}{c}S_{\rho_{r d}}^{2} \\
= \\
0,074 \\
(\mathrm{Mg} / \\
\left.\mathrm{m}^{3}\right)^{2}\end{array}$ & $\begin{array}{c}\rho_{r d}= \\
2,731- \\
0,0002 \\
L A\end{array}$ & 0,01 \\
\hline & $\begin{array}{l}r\left(X_{L A},\right. \\
\left.X_{\rho_{r d}}\right)\end{array}$ & $\begin{array}{c}\text { Nèra } \\
\text { koreliaci } \\
\text { jos }\end{array}$ & 11 & $\begin{array}{c}\bar{X}_{L A} \\
= \\
15,50\end{array}$ & $\begin{array}{c}\bar{X}_{\rho_{r d}} \\
=2,72 \\
8 \\
(\mathrm{Mg} / \\
\left.\mathrm{m}^{3}\right)\end{array}$ & $\begin{array}{c}S_{L A}^{2} \\
= \\
9,25\end{array}$ & $\begin{array}{c}S_{\rho_{r d}}^{2} \\
= \\
0,074 \\
(\mathrm{Mg} / \\
\left.\mathrm{m}^{3}\right)^{2}\end{array}$ & $\begin{array}{c}\rho_{r d}= \\
2,731- \\
0,0002 \\
L A\end{array}$ & 0,01 \\
\hline & $r\left(X_{S Z}, X_{F}\right)$ & $\begin{array}{l}\text { Labai } \\
\text { silpna } \\
\text { koreliaci } \\
\text { ja }\end{array}$ & 25 & $\begin{array}{c}\bar{X}_{S Z} \\
= \\
17,00 \\
(\%)\end{array}$ & $\begin{array}{c}\bar{X}_{F} \\
= \\
0,15 \\
\%\end{array}$ & $\begin{array}{c}S_{S Z}^{2} \\
= \\
2,285 \\
(\%)^{2}\end{array}$ & $\begin{array}{l}S_{F}^{2}= \\
0,010 \\
(\%)^{2}\end{array}$ & $\begin{array}{c}F= \\
-0,037 \\
+0,011 \\
S Z\end{array}$ & 0,17 \\
\hline & $r\left(X_{S Z}, X_{\rho_{r d}}\right)$ & $\begin{array}{l}\text { Vidutinè } \\
\text { koreliaci } \\
\text { ja }\end{array}$ & 66 & $\begin{array}{c}\bar{X}_{S Z} \\
= \\
17,31 \\
(\%)\end{array}$ & $\begin{array}{c}\bar{X}_{\rho_{r d}} \\
= \\
2,718 \\
(\mathrm{Mg} / \\
\left.\mathrm{m}^{3}\right)\end{array}$ & $\begin{array}{c}S_{S Z}^{2} \\
= \\
2,23 \\
(\%)^{2}\end{array}$ & $\begin{array}{c}S_{\rho_{r d}}^{2} \\
= \\
0,001 \\
(\mathrm{Mg} / \\
\left.\mathrm{m}^{3}\right)^{2}\end{array}$ & $\begin{array}{c}\rho_{r d}= \\
2,92- \\
0,011 \\
S Z\end{array}$ & 0,46 \\
\hline & $r\left(X_{\rho_{r d}}, X_{F}\right)$ & $\begin{array}{c}\text { Silpna } \\
\text { koreliaci } \\
\text { ja }\end{array}$ & 26 & $\begin{array}{c}\bar{X}_{\rho_{r d}} \\
= \\
2,722 \\
\left(\begin{array}{c}\mathrm{Mg} / \\
\left.\mathrm{m}^{3}\right)\end{array}\right.\end{array}$ & $\begin{array}{c}\bar{X}_{F} \\
= \\
0,15 \\
\%\end{array}$ & $\begin{array}{c}S_{\rho_{r d}}^{2} \\
= \\
0,003 \\
(\mathrm{Mg} / \\
\left.\mathrm{m}^{3}\right)^{2}\end{array}$ & $\begin{array}{l}S_{F}^{2}= \\
0,01 \\
(\%)^{2}\end{array}$ & $\begin{array}{c}F= \\
0,96- \\
0,3 \rho_{r d}\end{array}$ & 0,15 \\
\hline
\end{tabular}

3.8 lentelè. Koreliacijos įverčių vertinimo lentelè (Čekanavičius, Murauskas 2004)

Table 3.8. Evaluation of the correlation values (Čekanavičius, Murauskas 2004)

\begin{tabular}{|c|c|}
\hline Koreliacijos koeficiento vertės & Koreliacinè priklausomybès pobūdis \\
\hline $0,00-0,19$ & Labai silpna priklausomybè arba jos nèra visai \\
\hline $0,20-0,39$ & Silpna priklausomybè \\
\hline $0,40-0,69$ & Vidutinė priklausomybe \\
\hline $0,70-0,89$ & Stipri priklausomybe் \\
\hline $0,90-1,00$ & Labai stipri priklausomybe் \\
\hline
\end{tabular}


Nustatème granito ir dolomito skaldos fizinių ir mechaninių rodiklių koreliacijos priklausomybès tarp rodiklių: $L A$ ir $S Z ; L A$ ir tankio $\rho_{r d} ; L A$ ir $F ; S Z$ ir tankio $\rho_{r d}$; rodiklių $S Z$ ir $F$; tankio $\rho_{r d}$ ir rodiklio $F$. Lietuvoje asfaltiniams mišiniams dažniausiai naudojama granito ir dolomito skalda. Dèl analizuojamų rodikliu verčiu stygiaus statistiniai apskaičiavimai buvo atlikti ne visiems rodikliams. Koreliacijos priklausomybès buvo nustatytos tik tarp rodikliu $L A$ ir $S Z$; $L A$ ir tankio $\rho_{r d}$, rodiklio $S Z$ ir tankio $\rho_{r d}$.

Statistinių rodiklių indeksai nurodo tą skaldos uolieną, kurios kokybès rodiklis analizuojamas. Hipotezès, kad analizuojamų rodiklių dažniai histogramose pasiskirstę pagal normaluji skirstinį, buvo tikrinamos priimant reikšmingumo lygmeni $\alpha=0,05$.

3.9 lentelè. Koreliacinių priklausomybių tarp žvyro ir dolomito skaldos fizinių ir mechaninių rodiklių verčių suvestinè

Table 3.9. Summary values of the correlation dependencies between mechanical and physical indices of crushed gravel and crushed dolomite

\begin{tabular}{|c|c|c|c|c|c|c|c|c|c|}
\hline \multirow{2}{*}{$\begin{array}{l}\stackrel{2}{0} \\
: \stackrel{0}{0} \\
\\
\end{array}$} & \multirow[t]{2}{*}{$\begin{array}{c}\begin{array}{c}\text { Korelia- } \\
\text { cinès }\end{array} \\
\text { priklauso- } \\
\text { mybès }\end{array}$} & \multirow[t]{2}{*}{$\begin{array}{c}\text { Korelia- } \\
\text { cinès } \\
\text { priklauso- } \\
\text { mybès } \\
\text { pobūdis } \\
3 \\
\end{array}$} & \multirow{2}{*}{ 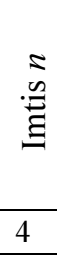 } & \multicolumn{2}{|c|}{ Vidurkiai } & \multicolumn{2}{|c|}{ Dispersija } & \multirow{2}{*}{$\begin{array}{l}\text { Regresi- } \\
\text { jos lygtis } \\
9\end{array}$} & \multirow{2}{*}{$\begin{array}{c}\text { Korelia- } \\
\text { cijos } \\
\text { koefici- } \\
\text { entas } r\end{array}$} \\
\hline & & & & 5 & 6 & 7 & 8 & & \\
\hline \multirow{4}{*}{ 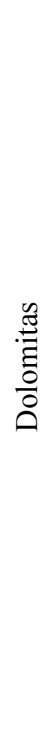 } & $r\left(X_{L A}, X_{F}\right)$ & $\begin{array}{c}\text { Labai } \\
\text { silpna } \\
\text { koreliacija }\end{array}$ & 12 & $\begin{array}{c}X \\
L A= \\
21,0\end{array}$ & $\begin{array}{c}\bar{X}_{F} \\
= \\
0,31 \\
\%\end{array}$ & $\begin{array}{c}S_{L A}^{2} \\
= \\
1,58\end{array}$ & $\begin{array}{c}S_{F}^{2} \\
= \\
0,01 \\
\mathbf{\%}^{2}\end{array}$ & $\begin{array}{c}F= \\
-0,0067+ \\
0,015 \cdot L A\end{array}$ & 0,16 \\
\hline & $r\left(X_{L A}, X_{S Z}\right)$ & $\begin{array}{c}\text { Stipri } \\
\text { koreliacija }\end{array}$ & 16 & $\begin{array}{c}\bar{X} \\
L A= \\
20,8\end{array}$ & $\begin{array}{c}\bar{X}_{S Z} \\
= \\
21,4 \\
\%\end{array}$ & $\begin{array}{c}S_{L A}^{2} \\
= \\
1,44\end{array}$ & $\begin{array}{c}S_{S Z}^{2} \\
= \\
1,55 \\
\mathbf{\%}^{2}\end{array}$ & $\begin{array}{c}S Z=6,39+ \\
0,72 \cdot L A\end{array}$ & 0,70 \\
\hline & $r\left(X_{L A}, X_{\rho_{r d}}\right)$ & $\begin{array}{c}\text { Vidutine } \\
\text { koreliacija }\end{array}$ & 16 & $\begin{array}{c}\bar{X} \\
L A= \\
20,2\end{array}$ & $\begin{array}{c}\bar{X}_{\rho_{r d}} \\
= \\
2,73 \\
\mathrm{Mg} / \\
\mathrm{m}^{3}\end{array}$ & $\begin{array}{c}S_{L A}^{2} \\
= \\
5,59\end{array}$ & $\begin{array}{c}S_{\rho_{r d}}^{2} \\
= \\
0,002 \\
(\mathrm{Mg} / \\
\left.\mathrm{m}^{3}\right)^{2} \\
\end{array}$ & $\begin{array}{c}L A= \\
68,26- \\
17,38 \cdot \rho_{r d}\end{array}$ & 0,47 \\
\hline & $r\left(X_{S Z}, X_{F}\right)$ & $\begin{array}{c}\text { Silpna } \\
\text { koreliacija }\end{array}$ & 38 & $\begin{array}{c}\bar{X}_{S Z} \\
=22 \\
\%\end{array}$ & $\begin{array}{c}\bar{X}_{F} \\
= \\
0,25 \\
\%\end{array}$ & $\begin{array}{c}S_{S Z}^{2} \\
= \\
1,18 \\
\%^{2}\end{array}$ & $\begin{array}{c}S_{F}^{2} \\
= \\
0,028 \\
\%^{2}\end{array}$ & $\begin{array}{c}F=-0,47+ \\
0,033 \cdot S Z\end{array}$ & 0,26 \\
\hline
\end{tabular}


3.9 lentelès pabaiga

The end of Table 3.9 .

\begin{tabular}{|c|c|c|c|c|c|c|c|c|c|}
\hline 1 & 2 & 3 & 4 & 5 & 6 & 7 & 8 & 9 & 10 \\
\hline \multirow{2}{*}{ 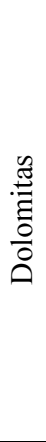 } & $r\left(X_{S Z}, X_{\rho_{r d}}\right)$ & $\begin{array}{l}\text { Nėra } \\
\text { koreliacij } \\
\quad \text { os }\end{array}$ & 94 & $\begin{array}{c}\bar{X}_{S Z} \\
= \\
22,3 \\
\%\end{array}$ & $\begin{array}{c}\bar{X}_{\rho_{r d}} \\
= \\
2,72 \\
\mathrm{Mg} / \\
\mathrm{m}^{3}\end{array}$ & $\begin{array}{c}S_{S Z}^{2} \\
= \\
2,12 \\
\%^{2}\end{array}$ & $\begin{array}{c}S_{\rho_{r d}}^{2} \\
= \\
0,001 \\
(\mathrm{Mg} / \\
\left.\mathrm{m}^{3}\right)^{2}\end{array}$ & $\begin{array}{c}S Z=31,12 \\
-3,83 \cdot \rho_{r d}\end{array}$ & 0,06 \\
\hline & $\left|r\left(X_{\rho_{r d}}, X_{F}\right)\right|$ & $\begin{array}{c}\text { Silpna } \\
\text { koreliacija }\end{array}$ & 37 & $\begin{array}{c}\bar{X}_{\rho_{r d}} \\
= \\
2,73 \\
\mathrm{Mg} / \\
\mathrm{m}^{3}\end{array}$ & $\begin{array}{c}\bar{X}_{F} \\
= \\
0,25 \\
\mathbf{\%}\end{array}$ & $\begin{array}{c}S_{\rho_{r d}}^{2} \\
= \\
0,001 \\
(\mathrm{Mg} / \\
\left.\mathrm{m}^{3}\right)^{2}\end{array}$ & $\begin{array}{c}S_{F}^{2} \\
= \\
0,010 \\
\%^{2}\end{array}$ & $\begin{array}{c}F=4,39- \\
1,52 \cdot \rho_{\text {rd }}\end{array}$ & 0,24 \\
\hline \multirow{3}{*}{, } & $r\left(X_{L A}, X_{S Z}\right)$ & $\begin{array}{c}\text { Stipri } \\
\text { koreliacija }\end{array}$ & 10 & $\begin{array}{c}\bar{X} \\
L A= \\
25,5\end{array}$ & $\begin{array}{c}\bar{X} \\
S Z= \\
23,07 \\
(\%)\end{array}$ & $\begin{array}{l}S_{L A}^{2} \\
= \\
8,65\end{array}$ & $\begin{array}{c}S_{S Z}^{2} \\
= \\
4,89 \\
(\%)^{2}\end{array}$ & $\begin{array}{c}S Z=7,018+ \\
0,63 \cdot L A\end{array}$ & 0,84 \\
\hline & $r\left(X_{L A}, X_{\rho_{r d}}\right)$ & $\begin{array}{c}\text { Silpna } \\
\text { koreliacija }\end{array}$ & 10 & $\begin{array}{c}\bar{X}_{L A} \\
= \\
25,5\end{array}$ & $\begin{array}{c}\bar{X}_{\rho_{r d}} \\
=2,7 \\
\mathrm{Mg} / \\
\mathrm{m}^{3}\end{array}$ & $\begin{array}{c}S_{L A}^{2} \\
= \\
8,65\end{array}$ & $\begin{array}{c}S_{\rho_{r d}}^{2} \\
= \\
0,001 \\
(\mathrm{Mg} / \\
\left.\mathrm{m}^{3}\right)^{2}\end{array}$ & $\begin{array}{c}L A=201,5 \\
2-65,22 \cdot \rho_{r d}\end{array}$ & 0,18 \\
\hline & $\left|r\left(X_{S Z}, X_{\rho_{r d}}\right)\right|$ & $\begin{array}{c}\text { Silpna } \\
\text { koreliacija }\end{array}$ & 16 & $\begin{array}{c}\bar{X}_{S Z} \\
= \\
23,2 \\
0 \%\end{array}$ & $\begin{array}{c}\bar{X}_{\rho_{r d}} \\
=2,7 \\
(\mathrm{Mg} / \\
\left.\mathrm{m}^{3}\right)\end{array}$ & $\begin{array}{c}S_{S Z}^{2} \\
= \\
4,59 \\
\%^{2}\end{array}$ & $\begin{array}{c}S_{\rho_{r d}}^{2} \\
= \\
0,001 \\
(\mathrm{Mg} / \\
\left.\mathrm{m}^{3}\right)^{2}\end{array}$ & $\begin{array}{c}S Z=- \\
52+27,83 \\
\rho_{r d}\end{array}$ & 0,30 \\
\hline
\end{tabular}

Hipotezès apie dažnių normalụji pasiskirstymą buvo tikrinamos tik tų rodiklių, kurių dažniai buvo išsidèstę normaliojo skirstinio tendencija. Jeigu braižant histogramą kreivè igauna apytiksliai simetrišką varpo formą, keliama hipotezė, kad duomenys pasiskirstę normaliai, dažniausiai pasitvirtina. Kuo daugiau veiksnių turi įtakos rodiklio vertei, tuo didesnè tikimybè, kad rodiklio duomenys bus pasiskirstę pagal normalujji skirstinį.

Koreliacinių priklausomybių tarp granito skaldos kokybės rodiklių verčių apskaičiavimas ir hipotezių apie duomenų normalujj pasiskirstymą patikra

Koreliacinei priklausomybei tarp rodiklių $L A$ ir $S Z$ verčiu apskaičiuoti atrinkta 16 granito skaldos bandinių $(n=16)$. Atlikę granito skaldos bandinių atsparumo trupinimui $L A$ ir smūginio trupio $S Z$ rodiklių verčiu statistinius skaičiavimus, gavome rodiklių $L A$ ir $S Z$ koreliacijos koeficientą $r=0,37$, regresijos lygtị $S Z=14,12+0,18 L A$, analizuotų verčių vidurkius $\bar{X}_{L A}=15,69$ ir 
$\bar{X}_{S Z}=16,98 \%$, verčiu dispersijas $S_{L A}^{2}=8,59$ ir $S_{S Z}^{2}=2,13(\%)^{2}$. Kadangi rodiklio $L A$ vertè $L A_{24}$ labai skyrèsi nuo likusių verčių, ją atmetėme. Dèl tos pačios priežasties atmetėme ir rodiklio $S Z$ vertę $S Z_{13,5}$. Toliau skaičiuodami naudojome imtis be šių verčių. Atmetę minètas rodiklių $L A$ ir $S Z$ vertes, gavome šiuos rezultatus: koreliacijos koeficientą $R=0,4952$, regresijos lygti $S Z=12,89+0,28 L A$, analizuotuc verčių vidurkius $\bar{X} \quad{ }_{L A}=15,14$ ir $\bar{X}_{S Z}=17,17 \%$ ir verčiu dispersijas $S_{L A}^{2}=4,55$ ir $S_{S Z}^{2}=1,49(\%)^{2}$. Pagal 3.8 lentelejje pateiktas koreliacijos koeficientų vertes, priklausomybę tarp rodiklių $L A$ ir $S Z$ verčių vertiname kaip vidutinę.

Atlikę granito skaldos bandinių atsparumo trupinimui rodiklio $L A$ ir tankio $\rho_{r d}$ verčių statistinius skaičiavimus, gavome rodiklio $L A$ ir tankio $\rho_{r d}$ verčiu koreliacinę priklausomybę, išreikštą koreliacijos koeficientu $r=-0,0075$, regresijos lygti $\rho_{r d}=2,73-0,0002 L A$, analizuotų verčių vidurkius $\bar{X}_{L A}=15,50 \mathrm{ir}$ $\bar{X}_{\rho_{r d}}=2,728 \mathrm{Mg} / \mathrm{m}^{3}$ ir dispersijas $S_{L A}^{2}=9,25$ ir $S_{\rho_{r d}}^{2}=0,074\left(\mathrm{Mg} / \mathrm{m}^{3}\right)^{2}$. Esant tokiam mažam koreliacijos koeficientui, galima teigti, kad koreliacinès priklausomybès tarp rodiklių $L A$ ir $\rho_{r d}$ praktiškai nèra.

Atlikę granito skaldos bandinių atsparumo trupinimui rodiklio $L A$ ir atsparumo šaldymui ir atšildymui rodiklio $F$ verčių statistinius skaičiavimus, gavome koreliacinę priklausomybę tarp rodiklių $L A$ ir $F$, išreikštą koreliacijos koeficientu $r=0,067$ ir regresijos lygtị $F=0,11+0,003 \mathrm{LA}$. Gavę artimą nuliui koreliacijos koeficientą, galime teigti, kad priklausomybès, tarp analizuotu rodiklių verčių praktiškai nèra.

Atlikę granito skaldos bandinių smūginio trupio rodiklio $S Z$ ir sausujų grūdelių tankio (SGT) rodiklio $\rho_{r d}$ verčių statistinius apskaičiavimus, gavome koreliacinę priklausomybę tarp rodiklio $S Z$ ir rodiklio $\rho_{r d}$ verčių, išreikštą koreliacijos koeficientu $r=-0,46$, regresijos lygti $\rho_{r d}=2,92-0,011 S Z$, analizuotu verčių vidurkius $\bar{X}_{S Z}=17,32 \%$ ir $\bar{X}_{\rho_{r d}}=2,718 \mathrm{Mg} / \mathrm{m}^{3}$ ir dispersijas $S_{S Z}^{2}=2,23(\%)^{2}$ ir $S_{\rho}^{2}=0,0013\left(\mathrm{Mg} / \mathrm{m}^{3}\right)^{2}$. Koreliacijos koeficiento vertè $r=-0,46$ rodo vidutinio stiprio atvirkštinę priklausomybę tarp rodiklių $S Z$ ir $\rho_{r d}$ verčių.

Atlikę granito skaldos bandinių smūginio trupio rodiklio $S Z$ ir atsparumo šaldymui ir atšildymui rodiklio $F$ verčių statistinius apskaičiavimus, gavome koreliacinę priklausomybę tarp rodiklių $S Z$ ir $F$ verčių, išreikštą koreliacijos koeficientu $r=0,17$, regresijos lygti $F=-0,037+0,011 S Z$, analizuotu verčių vidurkius $\bar{X}_{S Z}=17,0037 \%$ ir $\bar{X}_{F}=0,15 \%$ ir dispersijas $S_{S Z}^{2}=2,29(\%)^{2}$ ir $S_{F}^{2}=0,0097(\%)^{2}$. Apskaičiuota rodiklių $S Z$ ir $F$ koreliacijos koeficiento verte rodo labai silpną analizuojamų rodiklių verčių tarpusavio priklausomybę. Atsparumo smūginiam trupiui rodiklio $S Z$ verčių dažnių pasiskirstymo 
histogramą nubraižème atmetę akivaizdžiai išsiskiriančias vertes $(13,5,21,4$, 21,5), gavome $\bar{X}_{S Z}=17,24 \%, S_{S Z}^{2}=1,12(\%)^{2}$. Granito skaldos atsparumo trupinimui smūginiu metodu rodiklio $S Z$ verčių histograma pateikta 3.14 paveiksle.

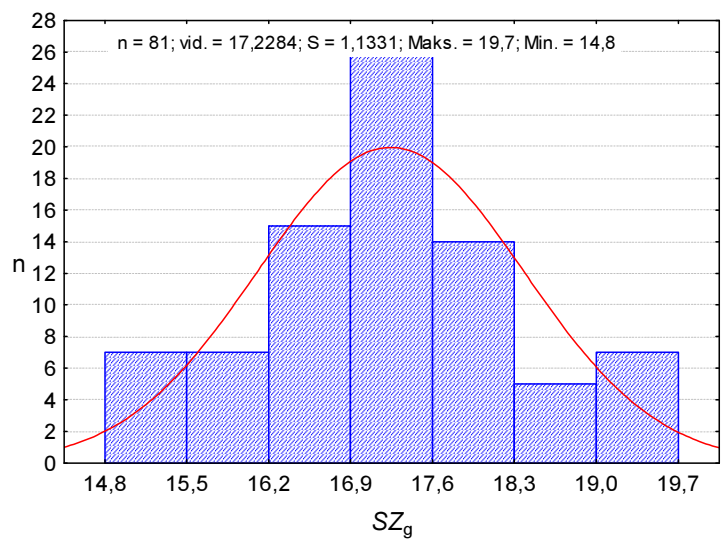

3.14 pav. Granito skaldos atsparumo trupinimui rodiklio verčių histograma ir skirstinio funkcija

Fig 3.14. Histogram of values and distribution function of the resistance to fragmentatizon index of crushed granite

Histogramą nubraižėme atvejui, kai intervalų pločiai vienodi, analizuojama imtis $n=81$, intervalo ilgị $h$ nustateme pagal (3.10) formulę: $h=0,98$, intervalų skaičius $k$ pasirinktas 7:

$$
h=\frac{X_{\max } X_{\min }}{k},
$$

čia $x_{\max }$ - didžiausioji rodiklio vertè, $x_{\min }$ - mažiausioji rodiklio vertè.

Kadangi granito skaldos kokybės rodiklio $S Z$ verčių dažnių histograma gali būti artima normaliajam skirstiniui, tikrinama hipotezé, ar granito skaldos smūginio stiprio tyrimų duomenys pasiskirstę pagal normalujị skirstinį. Kadangi pagal (3.10) formulę gavome, $\operatorname{kad} T_{\text {stat }}^{2}=7,774>T_{\text {krit }}^{2}=5,991$, tai hipotezè buvo atmesta. Skaičiavimų suvestinè pateikta 3.10 lenteleje.

Atlikę granito skaldos bandinių tankio $\rho_{r d}$ ir atsparumo šaldymui ir atšildymui rodiklio $F$ verčiu statistinius apskaičiavimus, gavome koreliacinę priklausomybę tarp rodiklių $\rho_{r d}$ ir $F$ verčių, išreikštą koreliacijos koeficientu $r=-0,15$ ir regresijos lygti $F=0,96-0,3 \rho_{r d}$. Kadangi apskaičiuotas koreliacijos koeficientas $r$ nesiekia vertès $r=0,19$, galima teigti, kad šių rodiklių tarpusavio priklausomybè labai silpna. 
Tikrinama hipoteze, kad granito skaldos SGT rodiklio $\rho_{r d}$ matavimų rezultatai pasiskirstę pagal normaluji skirstinị.

3.10 lentelè. Hipotezių apie turimų duomenų normaluji pasiskirstymą verčių suvestinè Table 3.10. Summary values of the hypotheses on the normal distribution of data available

\begin{tabular}{|c|c|c|c|c|c|c|c|c|}
\hline$\frac{\sqrt[\pi]{0}}{.0}$ & $\begin{array}{l}\frac{n}{7} \\
\frac{y}{7} \\
0 \\
\simeq\end{array}$ & 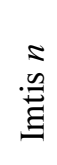 & 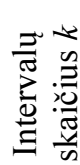 & $\begin{array}{l}\text { Aritmeti- } \\
\text { nis } \\
\text { vidurkis }\end{array}$ & Dispersija & $\begin{array}{c}\text { Statisti- } \\
\text { nė verte } \\
T_{\text {stat }}^{2}\end{array}$ & $\begin{array}{c}\text { Kritinè } \\
\text { verte் } \\
T_{k r i t}^{2}\end{array}$ & $\begin{array}{c}\text { Statusas dèl } \\
\text { normaliojo } \\
\text { pasiskirsty- } \\
\text { mo }\end{array}$ \\
\hline \multirow{2}{*}{ : } & $S Z, \%$ & 81 & 7 & $\begin{array}{c}\bar{X}_{S Z}= \\
17,24\end{array}$ & $\begin{array}{c}S_{S Z}^{2}= \\
1,12\end{array}$ & 7,77 & 5,99 & atmestas \\
\hline & $\begin{array}{c}\rho_{r d}, \\
\mathrm{Mg} / \mathrm{m}^{3}\end{array}$ & 67 & 7 & $\begin{array}{c}\bar{X}_{\rho_{r d}}= \\
2,713\end{array}$ & $\begin{array}{l}S_{\rho_{r d}}^{2}= \\
0,001\end{array}$ & 4,11 & 5,99 & Ne atmestas \\
\hline \multirow{2}{*}{ 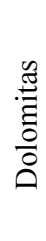 } & $S Z, \%$ & 135 & 7 & $\begin{array}{l}\bar{X}_{S Z}= \\
22,61\end{array}$ & $\begin{array}{c}S_{S Z}^{2}= \\
3,58\end{array}$ & 37,91 & 5,99 & atmestas \\
\hline & $\begin{array}{c}\rho_{r d}, \\
\mathrm{Mg} / \mathrm{m}^{3}\end{array}$ & 93 & 7 & $\begin{array}{c}\bar{X}_{\rho_{r d}}= \\
2,722\end{array}$ & $\begin{array}{c}S_{\rho_{r d}}^{2}= \\
0,001\end{array}$ & 9,96 & 5,99 & atmestas \\
\hline
\end{tabular}

Granito skaldos SGT rodiklio $\rho_{r d}$ histograma ir skirstinio funkcija pateikta 3.15 paveiksle.

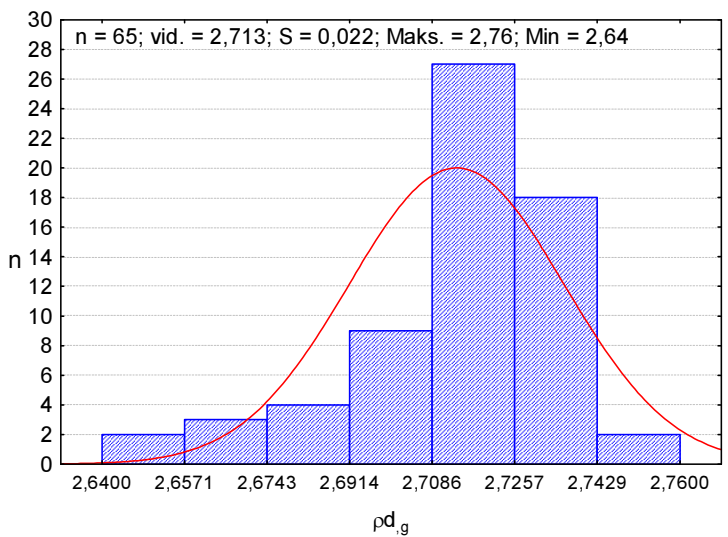

3.15 pav. Granito skaldos (fr. 8/12,5 mm) sausujų grūdelių tankio histograma ir skirstinio funkcija

Fig 3.15. Histogram and distribution function of the dry density of crushed granite grains (fraction 8/12,5) 
Atlikę statistinius skaičiavimus, atmetus stipriai išsiskiriančius tankio rezultatus $\left(2,86 \mathrm{Mg} / \mathrm{m}^{3} \quad\right.$ ir $\left.2,91 \mathrm{Mg} / \mathrm{m}^{3}\right)$, gavome $\quad \bar{X}_{\rho_{r d}}=2,713 \mathrm{Mg} / \mathrm{m}^{3} \quad$ ir $S_{\rho}^{2}=0,022\left(\mathrm{Mg} / \mathrm{m}^{3}\right)^{2}$. Kadangi $T_{\text {stat }}^{2}=4,110<T_{\text {krit }}^{2}=5,991$, hipotezès, kad granito skaldos tankio histograma pasiskirsčiusi pagal normalujji skirstinį, atmesti nèra pagrindo.

Koreliacinių priklausomybių tarp dolomito skaldos kokybès rodiklių $L A$ ir $S Z$ vertėms apskaičiuoti buvo atrinkta 16 bandinių $(n=16)$. Šioje imtyje atmestas išsiskiriantis ịvertis $X_{L A}=12$. Jis nebuvo ịtrauktas ị vèliau analizuotas imtis. Atlikę dolomito skaldos bandinių atsparumo trupinimui rodiklio $L A$ ir smūginio trupio rodiklio $S Z$ verčių statistinius skaičiavimus, gavome koreliacinę priklausomybę tarp rodiklių $L A$ ir $S Z$ verčių, išreikštą koreliacijos koeficientu $r=0,7$, regresijos lygtị $S Z=6,39+0,72 L A$, analizuotų verčių vidurkius $\bar{X}_{L A}=20,75$ ir $\bar{X}_{S Z}=21,42 \%$ ir imčiu dispersijas $S_{L A}^{2}=1,44$, ir $S_{S Z}^{2}=1,55(\%)^{2}$.

Apskaičiuojant koreliacinę priklausomybę tarp dolomito skaldos kokybès rodiklių, $L A$ ir $\rho_{r d}$ verčių, atrinkta 16 bandinių $(n=16)$ imtis. Apskaičiavę gavome koreliacijos koeficientą $r=-0,47$ ir regresijos lygti $L A=68,26-17,38 \rho_{r d}$. Esant tokiam koreliacijos koeficientui, galima teigti, kad priklausomybe tarp dolomito skaldos kokybès rodiklių, $L A$ ir $\rho_{r d}$ verčių yra vidutinè.

Atlikę dolomito skaldos kokybès rodiklių, $L A$ ir $F$ verčiu statistinius apskaičiavimus, gavome koreliacinę priklausomybę tarp rodiklių $L A$ ir $F$ verčių, išreikštą koreliacijos koeficientu $r=0,16$ ir regresijos lygtị $F=-0,0067+0,015 \mathrm{LA}$. Esant tokiam mažam koreliacijos koeficientui, galima teigti, kad tarp analizuotų rodiklių verčių priklausomybe labai silpna.

Koreliacinei priklausomybei tarp dolomito skaldos kokybės rodiklių $S Z$ ir $\rho_{r d}$ verčių apskaičiuoti buvo atrinkta 94 éminių imtis. Atlikę statistinius skaičiavimus, gavome šiuos rezultatus: koreliacijos koeficientą $r=-0,0622$, regresijos lygti $S Z=31,12-3,83 \rho_{r d}, \quad$ analizuotuc verčių vidurkius $\bar{X}_{S Z}=22,3160 \%$ ir $\bar{X}_{\rho_{r d}}=2,722 \mathrm{Mg} / \mathrm{m}^{3}$ bei dispersijas $S_{S Z}^{2}=2,15(\%)^{2}$ ir $S_{\rho_{r d}}^{2}=0,0008\left(\mathrm{Mg} / \mathrm{m}^{3}\right)^{2}$. Kai koreliacijos koeficientas artimas nuliui, galima teigti, kad priklausomybės tarp šių dviejų kokybès rodiklių verčiu praktiškai nèra.

Dolomito skaldos bandinių smūginio trupio rodiklio $S Z$ verčių ir jos atsparumo šaldymui ir atšildymui rodiklio $F$ verčių statistinius skaičiavimus atlikome kai imtis $n=38$. Gavome koreliacinę priklausomybę tarp rodiklių $S Z$ ir $F$ verčių, išreikštą koreliacijos koeficientu $r=0,26$, ir regresijos lygti $F=-0,47+0,033 S Z$. Remiantis apskaičiuotais statistiniais rodikliais galima teigti, kad priklausomybè tarp dolomito skaldos kokybès rodiklių $S Z$ ir $F$ verčiu yra silpna. 
Atlikę dolomito skaldos bandinių SGT rodiklio $\rho_{r d}$ ir atsparumo šaldymui ir atšildymui rodiklio $F$ verčiu statistinius apskaičiavimus, gavome koreliacinę priklausomybę tarp rodiklių $\rho_{\mathrm{rd}}$ ir $F$ verčių, išreikštą koreliacijos koeficientu $r=-0,24$, ir regresijos lygti $F=4,39-1,52 \rho_{\text {rd }}$. Imtis šiai statistinei analizei atlikti buvo sudaryta iš 37 verčių. Gautas koreliacijos koeficientas rodo silpną priklausomybę tarp tankio rodiklių $\rho_{r d}$ ir $F$ verčių.

Atsparumo smūginiam trupiui rodiklio $S Z$ verčių dažnių pasiskirstymo histogramą nubraižème imčiai, kurios $n=135$, o intervalų ilgis $h=1,48$. Tikrinta hipotezé, ar dolomito skaldos smūginio stiprio tyrimų rezultatai pasiskirstę pagal normaluji skirstini. Šios imties vidurkis $\bar{X}_{S Z}=22,61 \%$, o imties dispersija $S_{S Z}^{2}=3,58(\%)^{2}$. Kadangi gavome, kad $T_{\text {stat }}^{2}=37,914>T_{\text {krit }}^{2}=5,991$, tai ši hipoteze buvo atmesta. Dolomito skaldos atsparumo trupinimui smūginiu metodu rodiklio $S Z$ verčių histograma pateikta 3.16 paveiksle.

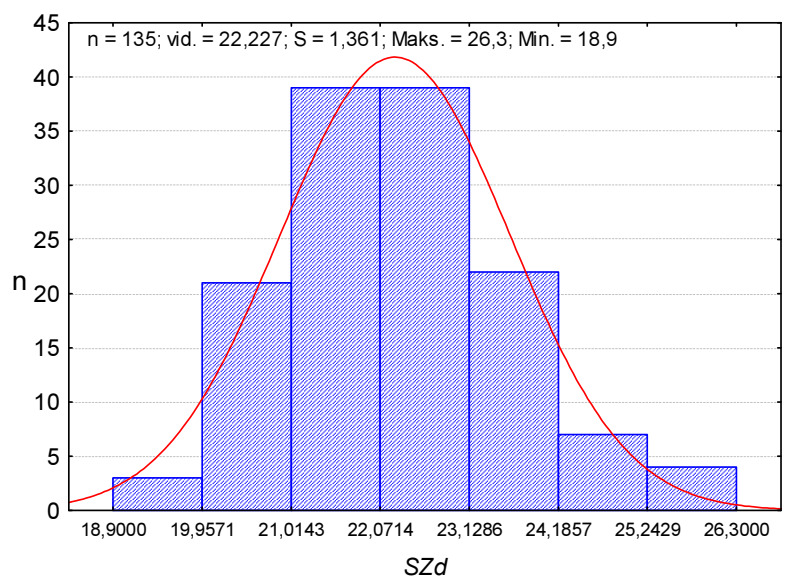

3.16 pav. Dolomito skaldos atsparumo trupinimui rodiklio verčių histograma ir skirstinio funkcija

Fig 3.16. Histogram of values and distribution function of the resistance to fragmentation index of crushed dolomite

Tikrinta hipotezè, kad dolomito skaldos SGT rodiklio $\rho_{r d}$ dažnių matavimo rezultatai pasiskirstę pagal normalujji skirstinị 3.17 (pav).

Analizuota imtis $n=93$, o intervalo ilgis $h=0,03$. Gavome $\bar{X}_{\rho_{r d}}$ $=2,722 \mathrm{Mg} / \mathrm{m}^{3}$ ir $S_{\rho_{r d}}^{2}=0,0008\left(\mathrm{Mg} / \mathrm{m}^{3}\right)^{2}$. Kadangi $T_{\text {stat }}^{2}=9,959>T_{\text {krit }}^{2}=5,991$, tai hipoteze, kad dolomito skaldos SGT rodiklio $\rho_{r d}$ tyrimo duomenys pasiskirstę pagal normaluji skirstini, buvo atmesta. 


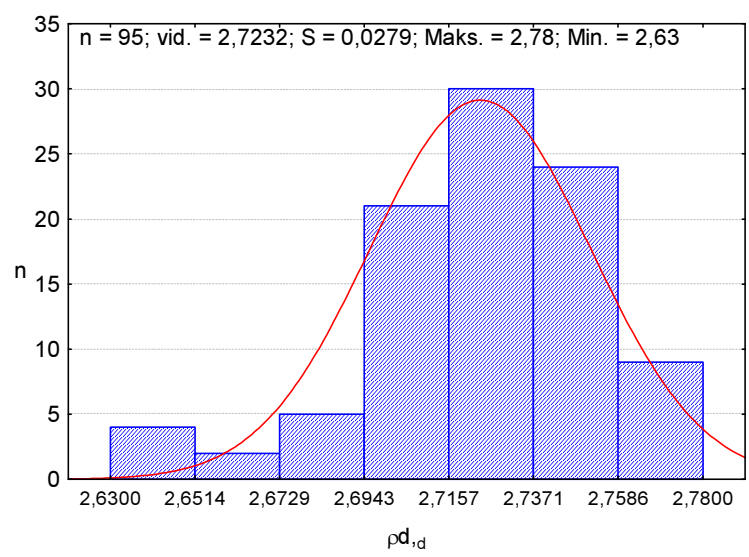

3.17 pav. Dolomito skaldos sausujų grūdelių tankio rodiklio histograma ir skirstinio funkcija

Fig. 3.17. Histogram and distribution function of the dry density index of crushed dolomite

Koreliacinių priklausomybių tarp žvyro skaldos kokybės rodiklių $L A$ ir $S Z$ vertèms apskaičiuoti buvo atrinkta 10 bandinių $(n=10)$ Atlikę žvyro skaldos bandinių atsparumo trupinimui rodiklio $L A$ verčiu ir smūginio trupio rodiklio $S Z$ verčių statistinius apskaičiavimus, gavome koreliacinę priklausomybę tarp rodiklių $L A$ ir $S Z$ verčių, išreikštą koreliacijos koeficientu $R=0,84$, regresijos lygti $S Z=7,02+0,63 L A$, analizuotu verčių vidurkius $\bar{X}{ }_{L A}=25,5$ ir $\bar{X}_{S Z}=23,07 \%$, dispersijas $S_{L A}^{2}=8,65$ bei $S_{S Z}^{2}=4,89(\%)^{2}$. Pagal 3.8 lenteleje pateiktus koreliacijos koeficientų ivverčius, nustatème, kad koreliacinè priklausomybė tarp rodiklių $L A$ ir $S Z$ verčių žvyro skaldai yra stipri.

Apskaičiuojant koreliacinę priklausomybę tarp žvyro skaldos bandinių atsparumo trupinimui rodiklio $L A$ ir SGT rodiklio $\rho_{r d}$ verčių, atrinkta 10 bandinių imtis. Gavome koreliacinę priklausomybę tarp žvyro skaldos rodiklių, $L A$ ir $\rho_{r d}$ verčių, išreiktą koreliacijos koeficientu $r=-0,18$, regresijos lygti $L A=201,52-65,22 \rho_{r d}$, analizuotų verčių vidurkius $\bar{X}_{L A}=25,5$ ir $\bar{X}_{\rho_{r d}}=2,699 \mathrm{Mg} / \mathrm{m}^{3}$ ir dispersijas $S_{L A}^{2}=8,65$ bei $S_{\rho_{r d}}^{2}=0,000069\left(\mathrm{Mg} / \mathrm{m}^{3}\right)^{2}$. Koreliacinè priklausomybe tarp rodiklių $L A$ ir $\rho_{r d}$ verčių žvyro skaldai yra labai silpna.

Apskaičiuojant koreliacinę priklausomybę tarp žvyro skaldos smūginio trupio rodiklio $S Z$ verčių ir jos SGT rodiklio $\rho_{r d}$ verčių, sudaryta 16 bandymų duomenų imtis $(n=16)$. Atlikę bandymą, gavome koreliacinę priklausomybę, išreikštą koreliacijos koeficientu $r=-0,3$, regresijos lygti $S Z=-52+27,83 \rho_{r d}$ ir 
analizuotų verčių vidurkius $\bar{X}_{S Z}=23,2 \%$ ir $\bar{X}_{\rho_{r d}}=2,702 \mathrm{Mg} / \mathrm{m}^{3}$, imčių dispersijas $S_{S Z}^{2}=4,59(\%)^{2}$ ir $S_{\rho_{r d}}^{2}=0,0005\left(\mathrm{Mg} / \mathrm{m}^{3}\right)^{2}$. Nustateme, kad tarp rodiklių $S Z$ ir $\rho_{r d}$ verčių koreliacinè priklausomybè yra silpna.

Pagal TRA MIN 07:2007 „Automobiliu keliu mineraliniu medžiagu techniniu reikalavimu aprašo" reikalavimus nustatyti skirtingi to paties tipo asfaltinių mišinių skaldos geometriniai rodikliai, todèl turi būti patikrintos ir ivertintos tirtos skaldos plokštumo rodiklio $F I$ ir formos rodiklio SI koreliacinès priklausomybès. Taip pat patikrintos skaldos geometrinių rodiklių koreliacinės priklausomybès su fiziniais kokybės ( $L A$ ir $S Z$ ) rodikliais. Analizuojamų rodiklių koreliacinès priklausomybès vertintos pagal koreliacijos koeficientus, pateiktus 3.9 lentelèje.

Kadangi Lietuvoje asfaltiniams mišiniams dažniausiai naudojama granito ir dolomito skalda, todèl nagrinèjamų kokybès rodiklių statistiniai skaičiavimai atlikti šių uolienų skaldai.

Kai nagrinejamų rodiklių imtis $n<10$, statistiniai skaičiavimai gaunami su labai didele paklaida. Todèl neatlikome šių tolesnių statistinių skaičiavimų: granito skaldos koreliaciniu priklausomybiu tarp plokštumo rodiklio $F I$ ir smūginio trupio $S Z$, formos rodiklio $S I$ ir atsparumo trupinimui koeficiento $L A$ bei plokštumo rodiklio $F I$ ir atsparumo trupinimui koeficiento $L A$. Taip pat buvo skaičiuota koreliacine granito skaldos rodiklių $S Z, S I$ ir sausujų dalelių tankio $\rho_{r d}$ matrica, tačiau koreliacijos koeficientas tarp $S I$ ir $\rho_{r d}$ verčiu buvo gautas $\mathrm{R}=-0,032$. Kadangi koreliacijos koeficientas artimas nuliui, tai tolesnių šios matricos skaičiavimas netenka prasmès.

Nustatant skaldos plokštumo rodiklio FI ir formos rodiklio SI koreliacinę priklausomybę, rezultatai pagal uolieną skirstomi nebuvo, nes šiuo atveju analizuojamas tik geometrinis skaldos parametras. Nustateme granito skaldos fizinių, mechaniniu ir geometriniu rodikliu koreliacijos priklausomybes tarp rodiklių $S I$ ir $S Z$ verčių, bei dolomito skaldos fizinių, mechaninių ir geometrinių rodikliu koreliacijos priklausomybes tarp rodiklių: $S I$ ir $S Z ; F I$ ir $S Z ; S I$ ir $L A ; F I$ ir $L A$ verčiu.

Koreliacinei priklausomybei tarp rodiklių FI ir SI verčiu skaičiuoti buvo atrinkta 134 skirtingos uolienos (granito, dolomito žvyro) skaldos bandinių $(n=134)$. Atlikę skaldos bandinių plokštumo rodiklio $F I$ ir formos rodiklio $S I$ verčių statistinius skaičiavimus, gavome rodiklių $F I$ ir $S I$ koreliacijos koeficientą $r=0,74$, regresijos lygti $S I=2,71+0,6 F I$, analizuotų verčių vidurkius $\bar{X}$ ${ }_{F I}=7,49 \%$ ir $\bar{X} \quad{ }_{S I}=8,015 \%$, verčiu dispersijas $S_{F I}^{2}=13,41(\%)^{2}$ ir $S_{S I}^{2}=20,58(\%)^{2}$. Pagal 3.7 lenteleje pateiktas koreliacijos koeficientų vertes, priklausomybę tarp rodiklių $F I$ ir $S I$ verčių vertiname kaip stiprią. 
Koreliacinei priklausomybei tarp rodikliu $S I$ ir $S Z$ verčių apskaičiuoti buvo atrinktas 51 granito skaldos bandinys $(n=51)$. Atlikę granito skaldos bandinių formos rodiklio $S I$ ir smūginio trupio rodiklio $S Z$ verčiu statistinius skaičiavimus gavome, analizuotų verčių vidurkius $\bar{X}_{S I}=10,13 \%$ ir $\bar{X}_{S Z}=22,12 \%$, dispersijas $S_{S I}^{2}=14,16(\%)^{2}$ bei $S_{S Z}^{2}=1,95(\%)^{2}$. Esant tokiam mažam koreliacijos koeficientui, galima teigti, kad koreliacinès priklausomybès tarp rodiklių $S I$ ir $S Z$ praktiškai nèra.

Koreliacinès priklausomybès tarp rodiklių $F I$ ir $S Z$ vertèms apskaičiuoti buvo atrinkta 17 dolomito skaldos bandinių $(n=17)$. Atlikę dolomito skaldos bandiniu plokštumo rodiklio $F I$ ir smūginio trupio rodiklio $S Z$ verčių statistinius skaičiavimus, gavome plokštumo rodiklio $F I$ ir smūginio trupio rodiklio $S Z$ koreliacinę priklausomybę, išreikštą koreliacijos koeficientu $r=0,57$, regresijos lygti $F I=18,96+0,35 S Z$, analizuotų verčių vidurkius $\bar{X}_{F I}=8,12 \%$ ir $\bar{X}_{S Z}=21,78 \%$, ir dispersijas $S_{F I}^{2}=5,87(\%)^{2}$ bei $S_{S Z}^{2}=2,19(\%)^{2}$. Esant koreliacijos koeficientui $r=0,57$, pagal 3.9 lenteleje pateiktas koreliacijos koeficientų vertes, priklausomybę tarp rodiklių $F I$ ir $S Z$ verčių vertiname kaip vidutinę.

Koreliacinès priklausomybès tarp formos rodiklio $S I$ ir atsparumo trupinimui rodiklio $L A$ verčių skaičiavimus buvo atrinkta 20 dolomito skaldos bandinių $(n=20)$. Atlikę dolomito skaldos bandinių formos rodiklio $S I$ ir atsparumo trupinimui rodiklio $L A$ verčių statistinius apskaičiavimus, gavome formos rodiklio $S I$ ir atsparumo trupinimui rodiklio $L A$ koreliacinę priklausomybę, išreikštą koreliacijos koeficientu $r=0,62$, regresijos lygtị $S I=19,25+0,35 L A$. Kadangi rodiklių $S I$ ir $L A$ vertès $(2 ; 22)$ ir $(3 ; 23)$ labai skyrèsi nuo likusių verčių, šias skaldos bandinių vertes atmetėme. Toliau skaičiuoti naudojome imtį be šių verčių. Atmetę minètas rodiklių $S I$ ir $L A$ vertes, gavome šiuos rezultatus: koreliacijos koeficientą $r=0,76$, regresijos lygti $S I=17,98+0,47 L A$, analizuotų verčių vidurkius $\bar{X}_{S I}=7,94 \%$ ir $\bar{X}_{L A}=21,72$ ir verčių dispersijas $S_{S I}^{2}=11,28(\%)^{2}$ ir $S_{L A}^{2}=4,31$. Pagal 3.8 lenteleje pateiktas koreliacijos koeficientų vertes, priklausomybę tarp rodiklių $S I$ ir $L A$ verčių vertiname kaip stiprią.

Koreliacinès priklausomybès tarp plokštumo rodiklio $F I$ ir atsparumo trupinimui rodiklio $L A$ vertems apskaičiuoti buvo atrinkta 18 dolomito skaldos bandinių $(n=18)$. Atlikę dolomito skaldos bandinių plokštumo rodiklio $F I$ ir atsparumo trupinimui rodiklio $L A$ verčiu statistinius skaičiavimus, gavome plokštumo rodiklio $F I$ ir atsparumo trupinimui rodiklio $L A$ koreliacinę priklausomybę, išreikštą koreliacijos koeficientu $r=0,64$, regresijos lygti $F I=18,29+0,42 L A$. Kadangi rodiklių $F I$ ir $L A$ vertès $(2 ; 22)$ labai skyrèsi nuo likusių verčių, šio skaldos bandinio vertes atmetème. Toliau skaičiuodami naudojome imtị be šių verčių. Atmetę minètas rodiklių $F I$ ir $L A$ vertes, gavome 
šiuos rezultatus: koreliacijos koeficientą $r=0,74$, regresijos lygti $F I=17,14+0,55 L A$, analizuotų verčių vidurkius $\bar{X}_{F I}=8,12 \%$ ir $\bar{X}_{L A}=21,54$ ir verčių dispersijas $S_{F I}^{2}=8,46(\%)^{2}$ ir $S_{L A}^{2}=4,71$.

\subsection{Trečiojo skyriaus išvados}

1. Bandymų ruožai automobilių kelių asfaltbetoninès dangos ir kelių dangos konstrukcijų sluoksnių kokybès rodikliams nustatyti turi būti parinkti taip, kad kiekviename iš šių ruožų kelių dangos konstrukcijų parametrai būtų kiek galima vienodesni.

2. Lietuvos magistraliniuose keliuose asfaltinejje dangoje dažniausiai dominuoja šie defektai: dangos suirtis dèl staigaus atšalimo (temperatūros plyšiai), plastinès liekamosios deformacijos (provėžos), dangos suirtis veikiant transporto priemonių apkrovoms dèl kelių dangos konstrukcijų nuovargio (nuovargio plyšiai), dangos erozija dèl temperatūros kaitos, jai (temperatūrai) labai dažnai (iki 80 ir daugiau kartų šaltojo sezono metu) pereinant iš teigiamosios i neigiamają ir iš neigiamosios ị teigiamajją.

3. Išanalizavus kelių dangos konstrukcijų sluoksnių medžiagų fizinių ir geometrinių rodikliu tyrimų rezultatus, nustatyta, kad Lietuvoje naudojamų mineralinių medžiagu geometrinès savybès atitinka aukštus norminių dokumentų keliamus reikalavimus šių medžiagų kokybei. Išanalizavus šių medžiagų mechaninių (atsparumo smūgiams ir trupinimui) rodiklių faktines vertes, nustatyta, kad labai dažnai (net iki 50 \% atvejų) šie rodikliai neatitinka Lietuvoje galiojančių norminių dokumentų reikalavimų, todèl šių rodiklių neatitiktis reikalavimams turi labai didelę neigiamą įtaką kelių dangos konstrukcijų stipriui (kelių dangos konstrukcijų stipris sumažejja).

4. Visų analizuotų geometrinių skaldos kokybės rodiklių imties asimetrijos koeficientai yra mažesni negu 0 . tai rodo imties verčių empirinio skirstinio dešinijji asimetrijos atveji. Granito ir dolomito skaldos bandinių imties asimetrijos koeficientas yra gerokai didesnis (kinta intervale $[0,42 ; 0,62]$ ), lyginant su žvyro skaldos analogišku koeficientu 0,14 . Tai reiškia, kad granito ir dolomito skaldos plokštumo ir formos rodiklių vertès labiau pasiskirsčiusios kairejje, aukštesnių verčių, vidurkio (medianos) pusejje, o žvyro skaldos imties vertès daugumoje išsidèsčiusios aplink vidutinę vertę. Tai patvirtina Lietuvoje naudojamų skaldos uolienų atitiktị aukštoms geometrinių kokybés rodiklių kategorijoms.

5. Patikrinus koreliacinius ryšius tarp skirtingų uolienų skaldos geometrinių ir stiprio rodiklių verčių, buvo nustatytas glaudus koreliacinis ryšys tarp plokštumo ir atsparumo trupinimui rodiklių. Šis faktas leidžia teigti, kad, nustačius plokštumo rodiklio vertę, galima atlikti gana tikslią tiriamos skaldos atsparumo 
smūgiams rodiklio vertès prognozę ir teigti, kad, atliekant skaldos kokybès kontrolę, tyrimų skaičių galima sumažinti ir atlikti tik skaldos plokštumo rodiklio bei atsparumo trupinimui tyrimus.

6. Visų tirtų uolienų fiziniai rodikliai, rodantys skaldos stiprumo savybes (atsparumą trupinimui ir atsparumą smūgiams), turi stiprų tarpusavio ryšį, nes gautose koreliacijos regresijos priklausomybèse koreliacijos koeficiento vertès buvo didesnès kaip 0,70 .

7. Pasinaudojus gautomis koreliacijos regresijos priklausomybėmis, galima pagerinti mineralinių medžiagų stiprumo savybių ìvertinimo kontrolę. Nedidinant sudètingu ir imlių laiko sąnaudoms atsparumo trupinimui ir smūgiams kontrolinių bandymų skaičiaus, siūloma dažniau nustatyti greitai ir palygint paprastai geometrinius mineralinių medžiagų parametrus apibūdinantị plokščiujų grūdelių kiekio medžiagoje rodiklį. 



\section{4}

\section{Konstrukciniu sluoksnių, ju medžiagu savybių analizè, vertinimas ir racionalių konstrukcijų parinkimas}

Skyriuje parengti dangos eksploatacinių rodikliu prognozės matematiniai modeliai, kai TP eismo intensyvumo rodiklis VMPEI kelyje yra $V M P E I \leq 10000$ aut./parą ir $V M P E I \leq 30000$ aut./parą. Sudarytas kelių dangos būklès prognozès sekos scheminis modelis. Sumodeliuotos ir pateiktos dvi racionalios magistraliniu kelių dangos konstrukcijos, kai $V M P E I \leq 10000$ aut./parą ir $V M P E I \leq 30000$ aut./parą. pateikti ekonominiai racionalių magistralinių kelių dangos konstrukcijų skaičiavimai.

Skyriaus tematika paskelbtas autoriaus straipsnis kartu su bendraautoriais (Bertulienè et al. 2011).

\subsection{Konstrukciniụ sluoksnių ir jų medžiagụ savybiụ itakos kelių tampriosios dangos viršutinio sluoksnio eksploataciniams rodikliams tyrimai bei analizè}

Atlikus pirmojo tyrimu ruožo (Kaunas-Marijampolé-Suvalkai (A5) 0,0-6,8 km) ir antrojo ruožo (Kaunas-Marijampolè-Suvalkai (A5) $25,8-30,3 \mathrm{~km}$ ) KDK 
matavimus ir medžiagų tyrimus laboratorijoje, nustatyti elementarių (20 m ilgio) tyrimų ruožų dangos būklès rodikliai $Y_{I R I}, H_{V}$ ir $D_{\mathrm{D}}$, taip pat KDK sluoksnių ir jų medžiagų kokybès rodikliai ir buvo apskaičiuotos statistinès jų charakteristikos. Buvo apskaičiuoti gautų rezultatų koreliacijos koeficientai ir nustatytas jų reikšmingumas sudarant analizuojamų rodiklių koreliacinių rodiklių matricą, pateiktą A priede. Taip pat patikrinti koreliaciniai ryšiai tarp kelio dangos kokybès rodiklių bei sudarytos tiesinès regresijos lygtys kelio dangos eksploataciniams rodikliams $Y_{I R I}$ ir $H_{V}$ vertinti. Suirties masto rodiklis $D_{\mathrm{D}}$ vertinamas nebuvo, nes jo vertès tiriamuosiuose kelio ruožuose daugiausiai buvo $D_{\mathrm{D}}=0$, o pavienès vertès nesiekè $3 \%$, t. y. danga buvo nedaug suirusi $-D_{\mathrm{D}} \leq 3 \%$ (Petkevičius 2008). Gautos mažos dangos suirties masto vertes parodo, kad po penkerių KD funkcionavimo metų atsirado tik plastinio pobūdžio defektų, kurie pasireišké dideliu kelio dangos lygumo $Y_{I R I}$ ir véžètumo $H_{V}$ pablogéjimu. Plastinių KD defektų atsiradimo priežastys tyrimų ruožuose galèjo būti šios:

- nepakankama KDK sluoksniams įrengti naudotų medžiagų kokybė;

- technologiniai nuokrypiai kelio tiesybos metu;

- kitos, kelio tiesybos metu atsiradusios aplinkybès (klimato kaita, tiesybos brokas, per žema specialistų kvalifikacija).

Statistiniais skaičiavimais buvo patikrinta, kaip kelio dangos kokybès rodikliai kiteja nepriklausomai nuo KDK sluoksnių ir jų medžiagų savybių. Analizuojamų rodiklių savybės lygtyse žymimos žymenimis ir atitinkamais indeksais, kurie nurodo KDK sluoksnị: indeksas $\mathrm{S}$ - viršutinị asfaltbetoninès (AB) dangos sluoksni, AS - apatini AB sluoksnį, PS - AB pagrindo sluoksnį, Sk - pagrindo skaldos sluoksni, ŠAS - apsaugini šalčiui atsparu smèlio sluoksni. Programine iranga „STATISTICA 7“ sudarytos KDK sluoksnių ir medžiagų kokybės rodiklių tiesinès priklausomybès regresinès lygtys: $(4.1,4.2) 1$-ojo kelio ruožo, kurio $V M P E I>30000$ aut./parą ir lygtys $(4.3,4.4)$ 2-ojo ruožo, kurio $V M P E I>10000$ aut./parą.

$$
\begin{aligned}
& Y_{\mathrm{IRI}}=0,114 V_{\mathrm{S}}+0,203 B_{\mathrm{S}}+0,446 S K_{\mathrm{S}}+0,014 M M_{\mathrm{S}}+0,267 B / M M_{\mathrm{S}}-0,075 V_{\mathrm{AS}^{-}} \\
& 0,287 B_{\mathrm{AS}^{-}}-0,151 S K_{\mathrm{AS}}+0,023 M M_{\mathrm{AS}}-0,321 B / M M_{\mathrm{AS}}-0,318 V_{\mathrm{PS}^{-}}-0,136 B_{\mathrm{PS}}+ \\
& 0,085 S K_{\mathrm{PS}}-0,321 M M_{\mathrm{PS}}+0,068 B / M M_{\mathrm{PS}}+0,351 k_{\mathrm{S}}-0,147 k_{\mathrm{AS}}+0,093 k_{\mathrm{PS}^{-}} \\
& 0,289 h_{\mathrm{S}}+0,01 h_{\mathrm{AS}}+0,071 h_{\mathrm{PS}}-0,066 h_{\mathrm{Sk}}+0,214 h_{\mathrm{S}} \mathrm{AS}, \text { kai } R^{2}=0,69 \text {, } \\
& H_{\mathrm{V}}=0,118 V_{\mathrm{S}^{-}} 0,078 B_{\mathrm{S}}+0,467 S K_{\mathrm{S}}+0,023 M M_{\mathrm{S}}-0,069 B / M M_{\mathrm{S}}+0,072 V_{\mathrm{AS}}+ \\
& 0,117 B_{\mathrm{AS}}+0,33 S K_{\mathrm{AS}}+0,023 M M_{\mathrm{AS}}+0,104 B / M M_{\mathrm{AS}}+0,078 V_{\mathrm{PS}}+0,212 B_{\mathrm{PS}}+ \\
& 0,055 S K_{\mathrm{PS}}-0,119 M M_{\mathrm{PS}}+0,082 B / M M_{\mathrm{PS}}+0,325 k_{\mathrm{S}}+0,042 k_{\mathrm{AS}}+0,014 k_{\mathrm{PS}}+ \\
& 0,299 h_{\mathrm{S}}+0,017 h_{\mathrm{AS}}-0,184 h_{\mathrm{PS}}+0,104 h_{\mathrm{Sk}}-0,522 h_{\mathrm{S}} \mathrm{AS} \text {, kai } R^{2}=0,83 \text {, }
\end{aligned}
$$




$$
\begin{aligned}
& Y_{\text {IRI }}=0,134 V_{\mathrm{S}^{-}}-0,142 B_{\mathrm{S}}-0,05 S K_{\mathrm{S}}-0,124 M M_{\mathrm{S}}+0,044 B / M M_{\mathrm{S}}+0,117 V_{\mathrm{AS}^{-}} \\
& 0,033 B_{\mathrm{AS}^{-}}-0,257 S K_{\mathrm{AS}}+0,027 M M_{\mathrm{AS}^{-}}-0,056 B / M M_{\mathrm{AS}}+0,303 V_{\mathrm{PS}}+0,09 B_{\mathrm{PS}^{-}} \\
& 0,179 S K_{\mathrm{PS}}+0,212 M M_{\mathrm{PS}}-0,223 B / M M_{\mathrm{PS}}-0,126 k_{\mathrm{S}}-0,161 k_{\mathrm{AS}}-0,162 k_{\mathrm{PS}}+ \\
& 0,175 h_{\mathrm{S}}+0,217 h_{\mathrm{AS}}+0,115 h_{\mathrm{PS}}+0,533 h_{\mathrm{Sk}}+0,409 h_{\mathrm{S}} \mathrm{AS} \text {, kai } R^{2}=0,69 \text {, } \\
& H_{\mathrm{V}}=0,458 \cdot V_{\mathrm{S}}+0,166 \cdot B_{\mathrm{S}}+0,065 \cdot S K_{\mathrm{S}}+0,012 \cdot M M_{\mathrm{S}}+0,082 \cdot B / M M_{\mathrm{S}^{-}} \\
& 0,144 \cdot V_{\mathrm{AS}}-0,124 \cdot B_{\mathrm{AS}}+0,308 \cdot S K_{\mathrm{AS}}+0,056 \cdot M M_{\mathrm{AS}}-0,256 \cdot B / M M_{\mathrm{AS}}+ \\
& 0,277 \cdot V_{\mathrm{PS}}+0,326 \cdot B_{\mathrm{PS}}-0,289 \cdot S K_{\mathrm{PS}}+0,37 \cdot M M_{\mathrm{PS}}-0,154 \cdot B / M M_{\mathrm{PS}}-0,24 \cdot k_{\mathrm{S}}+ \\
& 0,022 \cdot k_{\mathrm{A}}-0,011 \cdot k_{\mathrm{PS}}-0,189 \cdot h_{\mathrm{S}}+0,24 \cdot h_{\mathrm{AS}}-0,123 \cdot h_{\mathrm{PS}}+0,07 \cdot h_{\mathrm{Sk}}-0,08 \cdot h_{\mathrm{S}} \mathrm{AS} \text {, } \\
& \text { kai } R^{2}=0,85 \text {, }
\end{aligned}
$$

čia $Y_{\mathrm{IRI}}-$ kelių dangos lygumo tarptautinis rodiklis, $\mathrm{m} / \mathrm{km} ; H_{\mathrm{V}}-$ kelio dangos veežès gylis, $\mathrm{mm} ; V_{\mathrm{S}}, V_{\mathrm{AS}}, V_{\mathrm{PS}}-$ atitinkamo asfaltbetonio $(\mathrm{S}-$ viršutinis asfaltbetoninès dangos sluoksnis; AS - apatinis asfaltbetoninès dangos sluoksnis; PS - asfaltbetoninès dangos pagrindo sluoksnis) turštymètumo rodiklis, $\% ; B_{\mathrm{S}}, B_{\mathrm{AS}}, B_{\mathrm{PS}}$ - atitinkamo asfaltbetonio sluoksnio bituminio rišiklio kiekis, masès \%; $S K_{\mathrm{S}}, S K_{\mathrm{AS}}, S K_{\mathrm{PS}}-$ atitinkamo sluoksnio asfaltbetonio mineralinès medžiagos, liekančios ant $2 \mathrm{~mm}$ skersmens akelių sieto, kiekis masès $\% ; M M_{\mathrm{S}}, M M_{\mathrm{AS}}, M M_{\mathrm{PS}}$ - atitinkamo sluoksnio asfaltbetonio mineralinès medžiagos prabyrančios pro $0,09 \mathrm{~mm}$ skersmens akelių sietą, kiekis masės $\%$; $B / M M_{\mathrm{S}}, B / M M_{\mathrm{AS}}, B / M M_{\mathrm{PS}}-$ atitinkamo sluoksnio asfaltbetonio bituminio rišiklio ir mineralinių milteliu santykis; $k_{\mathrm{S}}, k_{\mathrm{AS}}, k_{\mathrm{PS}}-$ atitinkamo sluoksnio asfaltbetonio sutankinimo rodiklis, $\% ; h_{\mathrm{S}}, h_{\mathrm{AS}}, h_{\mathrm{PS}}, h_{\mathrm{Sk}}, h_{\mathrm{S} \text { AS }}-$ atitinkamų kelio dangos konstrukcijos sluoksnių storiai (asfaltbetoninès dangos sluoksniu išreikšti - 0,01 m, biriujų medžagų pagrindo sluoksnių išreikšti $-0,1 \mathrm{~m}$ ).

Regresijos modelis - statistinis modelis, leidžiantis vieno kintamojo vertes prognozuoti pagal kito kintamojo vertes. Šiam modeliui sudaryti taikoma regresine analize - tai statistiniai metodai, skirti regresijos modeliui sudaryti ir patikrinti, ar jis tinkamas, bei taikyti prognozėms.

Atlikus šiuos veiksmus, gaunama vienpusé statistinè priklausomybè regresijos funkcija, kuri nustato ryšį tarp kintamujų ir ịvertina statistinio ryšio formą. Tokios funkcijos sukūrimas naudingas tuo, kad juo remiantis galima apskaičiuoti tiriamojo kelio ruožo dangos būklès rodiklius $Y_{\mathrm{IRI}}$ ir $H_{\mathrm{V}}$, pakitus vienai, kelioms ar net visoms analizuojamų rodiklių vertėms, lemiančioms nagrinèjamo rodiklio vertes. Gauti gana aukšti determinacijos koeficientai $R^{2}$ (pirmojo tyrimu ruožo $R^{2}=0,69$ ir $R^{2}=0,83$, o tyrimų antrojo tyrimų ruožo $R^{2}=0,69$ ir $\left.R^{2}=0,85\right)$ leidžia daryti išvadą, kad sudarytų lygčių kintamieji (rodikliai) sąveikauja pakankamai stipriai. Remiantis atliktu tyrimu sudaromas kelio dangos prognozavimo tyrimu sekos scheminis modelis pateiktas 4.1 paveiksle.

Atlikus statistinius analizuotu rodiklių skaičiavimus ir sudarius KDK sluoksnių ir jų medžiagų kokybės rodiklių tiesinès priklausomybès regresijos 
lygtis $(4.1,4.2,4.3,4.4)$, galima parinkti racionalią kelio dangos konstrukciją esant ekvivalentiniam (tam tikram) TP eismo intensyvumui. Šiam tikslui pasiekti reikia atlikti lygčių $(4.1,4.2,4.3,4.4)$ rodiklių jautrumo analizę ir atlikti kintamujų (rodiklių) modeliavimo rezultatų neapibrèžties tikimybinę analizę.

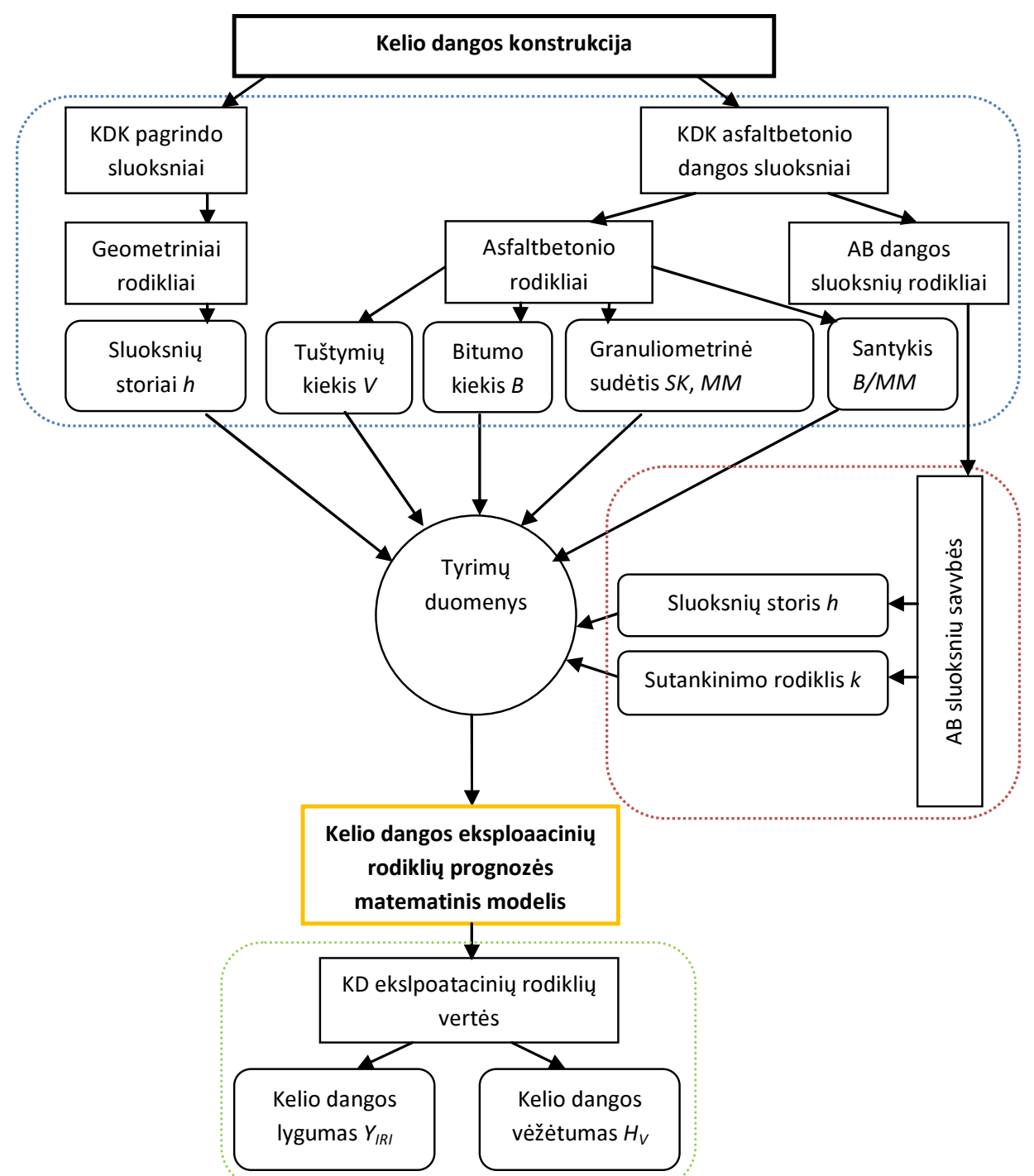

4.1 pav. Kelio dangos eksploatacinių rodiklių prognozès sekos scheminis modelis

Fig. 4.1. Schematic model for the sequence of predicting the road pavement service indices 
Gauti rezultatai leis nustatyti prognozuojamų rodiklių vertes, esant tam tikrai tikimybei. Atmetus sugeneruotų rodiklių aibę kuri nepatenka ị apibrèžtos kumuliacinès kreivès tikimybių sriti, galima nustatyti analizuojamų rodiklių vertes ir apskaičiuoti jų ịtaką visos kelio dangos konstrukcijos kainai.

Išanalizavus gautus rezultatus ir ivvertinus ribines kelio dangos eksploatacinių rodiklių vertes ir KDK kainą (tam tikram eismo intensyvumui), galima parinkti racionalią KDK.

\subsection{Konstrukcinių sluoksnių ir jų medžiagụ savybių vertinimas}

Naudojantis eksperimentiniu tyrimų duomenimis, empiriniu būdu sudaryti tiriamujų rodiklių priklausomybès nuo ịvesties parametrų (kintamųjų) matematiniai modeliai. Šie modeliai pagristi tiesinès priklausomybès tarp kintamujų ir nagrinejjamo rodiklio buvimu. Kadangi siekiamas rezultatas - gauti kuo mažesnę kelio dangos būklès rodiklių prognozès duomenų sklaidą, reikia mažinti kintamuju neapibrèžti, t. y. stiprinti statistiškai reikšmingų rodiklių, kurie turi didžiausią ịtaką nagrinèjamo parametro vertei, kontrolę. Tai reiškia, gerinti konkrečių KDK įrengimo technologinių procesų kokybę ir jų priežiūrą.

Jautrumo analizei atlikti taikytas Monte Karlo metodas (metodas aprašytas 3.1.3 poskyryje), o jautrumo indeksais pasirinkti standartizuotos regresijos koeficientai (SRK) pateikti 4.1 lentelèje. Kiekvieno nagrinejjamo rodiklio ( $Y_{\text {IRI}}$, $\left.H_{\mathrm{v}}\right)$ atveju priklausomybe išreikšta tiesinèmis regresinèmis lygtimis pirmajam $(4.1,4.2)$ ir anrajam $(4.3,4.4)$ tyrimų ruožams. Norint išsiaiškinti lygčių kintamuosius ( $Y_{\mathrm{IRI}}-$ kelių dangos lygumo tarptautinis rodiklis; $H_{\mathrm{V}}-$ kelio dangos véžès gylis; $V_{\mathrm{S}}, V_{\mathrm{AS}}, V_{\mathrm{PS}}-$ asfaltinio mišinio tuštymètumo rodiklis; $B_{\mathrm{S}}$, $B_{\mathrm{AS}}, B_{\mathrm{PS}}-$ monolitinių sluoksnių asfaltbetonio bituminio rišiklio $B$ kiekis; $S K_{\mathrm{S}}$, $S K_{\mathrm{AS}}, S K_{\mathrm{PS}}$ - sluoksnių asfaltbetonio mineralinès medžiagos likučio ant $2 \mathrm{~mm}$ skersmens akeliu sieto kiekis; $M M_{\mathrm{S}}, M M_{\mathrm{AS}}, M M_{\mathrm{PS}}-$ sluoksniu asfaltbetonio mineralinès medžiagos, prabyrančios pro $0,09 \mathrm{~mm}$ skersmens akelių sietą, kiekis; $B / M M_{\mathrm{S}}, B / M M_{\mathrm{AS}}, B / M M_{\mathrm{PS}}-$ sluoksnių asfaltbetonio bituminio rišiklio ir mineralinių milteliu santykis; $k_{\mathrm{S}}, k_{\mathrm{AS}}, k_{\mathrm{PS}}-$ asfaltbetonio sluoksnių sutankinimo rodiklis; $h_{\mathrm{S}}, h_{\mathrm{AS}}, h_{\mathrm{PS}}, h_{\mathrm{Sk}}, h_{\text {S̆AS }}-$ kelio dangos konstrukcijos sluoksnių storis), turinčius didžiausią įtaką rezultato neapibrěžčiai, atlikta jautrumo analizè. 
4.1 lentelè. Pirmojo ir antrojo kelio ruožų dangos būklès vertinimo lygčių standartizuotos regresijos koeficientai

Table 4.1. Standardized regression coefficients of equations for determining pavement service indices of the first and second experimental sections

\begin{tabular}{|c|c|c|c|c|}
\hline Kelio ruožas & \multicolumn{2}{|c|}{ Pirmasis } & \multicolumn{2}{|c|}{ Antrasis } \\
\hline Rodiklis & $Y_{\text {IRI }}$ & $H_{\mathrm{v}}$ & $Y_{\text {IRI }}$ & $H_{\mathrm{v}}$ \\
\hline$V_{\mathrm{S}}$ & 0,114 & 0,118 & 0,134 & 0,458 \\
\hline$B_{\mathrm{S}}$ & 0,203 & $-0,078$ & $-0,142$ & 0,166 \\
\hline$S K_{\mathrm{S}}$ & 0,446 & 0,467 & $-0,050$ & 0,065 \\
\hline$M M_{\mathrm{S}}$ & 0,014 & 0,023 & $-0,124$ & 0,012 \\
\hline$B / M M_{\mathrm{S}}$ & 0,267 & $-0,069$ & 0,044 & 0,082 \\
\hline$V_{\mathrm{AS}}$ & $-0,075$ & 0,072 & 0,117 & $-0,144$ \\
\hline$B_{\mathrm{AS}}$ & $-0,287$ & 0,117 & $-0,033$ & $-0,124$ \\
\hline$S K_{\mathrm{AS}}$ & $-0,151$ & 0,330 & $-0,257$ & 0,308 \\
\hline$M M_{\mathrm{AS}}$ & 0,023 & 0,023 & 0,027 & 0,056 \\
\hline$B / M M_{\mathrm{AS}}$ & $-0,321$ & 0,104 & $-0,056$ & $-0,256$ \\
\hline$V_{\mathrm{PS}}$ & $-0,318$ & 0,078 & 0,303 & 0,277 \\
\hline$B_{\mathrm{PS}}$ & $-0,136$ & 0,212 & 0,090 & 0,326 \\
\hline$S K_{\mathrm{PS}}$ & 0,085 & 0,055 & $-0,179$ & $-0,289$ \\
\hline$M M_{\mathrm{PS}}$ & $-0,321$ & $-0,119$ & 0,212 & 0,370 \\
\hline$B / M M_{\mathrm{PS}}$ & 0,068 & 0,082 & $-0,223$ & $-0,154$ \\
\hline$k_{\mathrm{S}}$ & 0,351 & 0,325 & $-0,126$ & $-0,240$ \\
\hline$k_{\mathrm{AS}}$ & $-0,147$ & 0,042 & $-0,161$ & 0,022 \\
\hline$k_{\mathrm{PS}}$ & 0,093 & 0,014 & $-0,162$ & $-0,011$ \\
\hline$h_{\mathrm{S}}$ & $-0,289$ & 0,299 & 0,175 & $-0,189$ \\
\hline$h_{\mathrm{AS}}$ & 0,010 & 0,017 & 0,217 & 0,240 \\
\hline$h_{\mathrm{PS}}$ & 0,071 & $-0,184$ & 0,115 & $-0,123$ \\
\hline$h_{\mathrm{Sk}}$ & $-0,066$ & 0,104 & 0,533 & 0,070 \\
\hline$h_{\mathrm{S}} \mathrm{AS}$ & 0,214 & $-0,522$ & 0,409 & $-0,080$ \\
\hline
\end{tabular}

Neapibrèžties analizès metu Monte Karlo metodu sugeneruota 1000 analizuojamų rodiklių verčių aibè. 


\subsubsection{Pirmojo tyrimų ruožo rodikliụ jautrumo analizè}

Regresinès analizès metu gautas determinacijos koeficientas $\left(R^{2}=1\right)$ leido jautrumo indeksais naudoti standartizuotos regresijos koeficientus (SRK). Pirmojo tyrimų ruožo rodiklio $Y_{\text {IRI }}$ lygties apskaičiuoti jautrumo indeksai pateikti 4.2 paveiksle.

Kaip matyti iš gautų rezultatų 4.2 paveiksle, rodiklio $Y_{I R I}$ neapibréžčiai didžiausią itaką turi parametrų $S K_{\mathrm{S}}$ (viršutinio sluoksnio asfaltbetonio mineralinès medžiagos likutis ant $2 \mathrm{~mm}$ skersmens akelių sieto) ir $k_{\mathrm{S}}$ (viršutinio asfaltbetoninès dangos sluoksnio storis) neapibrèžtis, kiek mažiau reikšminga rodiklių $B / M M_{\mathrm{AS}}$ (apatinio sluoksnio asfaltbetonio bituminio rišiklio ir mineraliniu miltelių santykis), $V_{\mathrm{PS}}$ (pagrindo sluoksnio asfaltbetonio tuštymètumo rodiklis) ir $M M_{\mathrm{PS}}$ (pagrindo sluoksnio asfaltbetonio mineralinès medžiagos, prabyrančios pro $0,09 \mathrm{~mm}$ skersmens akelių sietą, kiekis) neapibrèžtis.

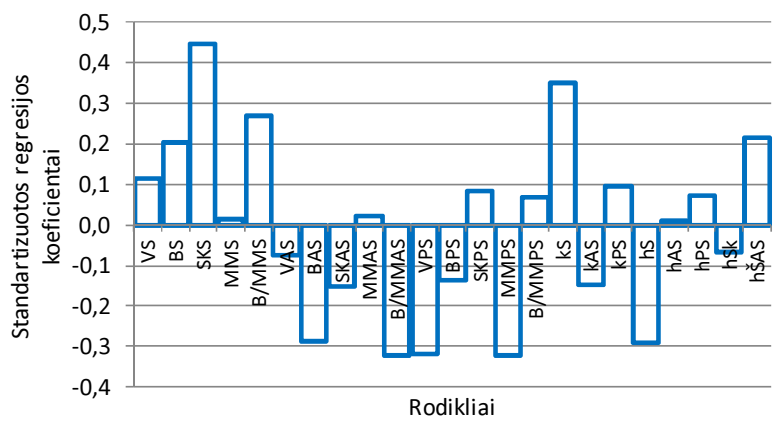

4.2 pav. Pirmojo tyrimų ruožo dangos lygumo rodiklio modeliavimo tikimybinès jautrumo analizès rezultatai

Fig. 4.2. Results of probabilistic sensitivity analysis of roughness index modelling for the first experimental road section

Teigiamos jautrumo indeksų SRK vertès rodo, kad, didèjant šiems parametrams, rodiklio $Y_{I R I}$ vertès taip pat didejja. Tarp nagrinejjamo dangos lygumo rodiklio $Y_{I R I}$ verčių ir reikšmingų rodiklių $B_{\mathrm{AS}}, B / M M_{\mathrm{AS}}, V_{\mathrm{PS}}, M M_{\mathrm{PS}}, h_{\mathrm{S}}$ (atitinkamai apatinio asfaltbetonio sluoksnio bituminio rišiklio kiekio ir jo santykio su mineraliniais milteliais, pagrindo sluoksnio asfaltbetonio tuštymètumo rodiklio ir mineraliniu miltelių kiekis bei asfaltbetoninès dangos viršutinio sluoksnio storio) esti atvirkštiné priklausomybe - didejjant nurodytu rodikliu vertèms, rodiklio $Y_{I R I}$ igyjama verte mažèja. Naudojantis gautais rezultatais ir siekiant sumažinti $Y_{I R I}$ neapibrezžti, tikslinga orientuoti tolesnius tyrimus pirmiausia ị tikslesnị išskirtų 
parametrų neapibrèžties ịvertinimą. Tai galima pasiekti, didinant kontrolès bandymų skaičių, tikrinant $\mathrm{AB}$ dangos viršutinio sluoksnio įrengimo metu skaldos frakcijos asfaltbetonyje kieki ir gerinant $\mathrm{AB}$ viršutinio sluoksnio i̇rengimo darbų kontrolę. Kitų analizuotų rodiklių neapibrěžtis neturi reikšmingos įtakos rodiklio $Y_{I R I}$ modeliavimo rezultatų neapibrěžčiai.

Vèžès gylio rodiklio $H_{\mathrm{v}}$ gautų modeliavimo rezultatų pateiktų 4.3 paveiksle neapibrěžčiai didžiausią įtaką turi rodiklio $S K_{, S}$ (viršutinio sluoksnio asfaltbetoninès dangos mineralinès medžiagos likučio ant $2 \mathrm{~mm}$ skersmens akelių sieto kiekio), kaip ir rodiklio $Y_{I R I}$ atveju, ir rodiklio $h_{\text {S̆AS }}$ (apsauginio šalčiui atsparaus sluoksnio storio) neapibrèžtis $(\mathrm{SRK}=0,47$ ir $(-0,52)$, atitinkamai), kiek mažiau reikšminga rodiklių $S K_{\mathrm{AS}}, B_{\mathrm{PS}}, k_{\mathrm{S}}$ ir $h_{\mathrm{S}}$ (atitinkamai apatinio sluoksnio asfaltbetonio mineralinès medžiagos likučio ant $2 \mathrm{~mm}$ skersmens akeliu sieto, pagrindo sluoksnio asfaltbetonio bituminio rišiklio kiekio ir asfaltbetoninès dangos viršutinio sluoksnio storio ir sutankinimo koeficiento) neapibrežztis (SRK nuo 0,2 iki 0,3 ).

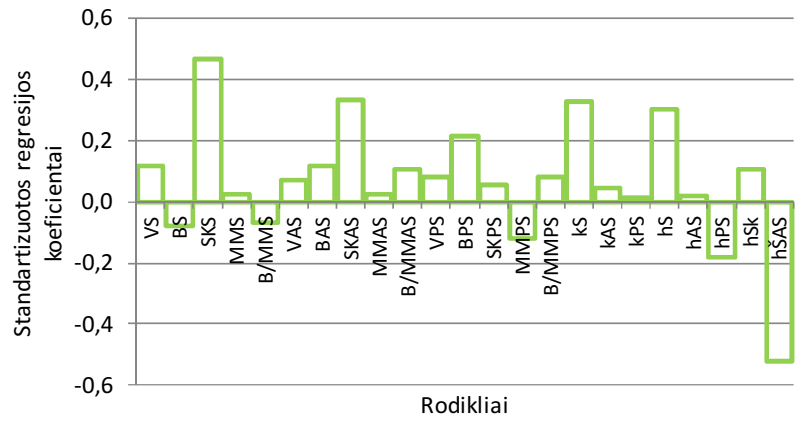

4.3 pav. Pirmojo tyrimų ruožo vėžètumo rodiklio modeliavimo tikimybinės jautrumo analizès rezultatai

Fig. 4.3. Results of probabilistic sensitivity analysis of rutting index modelling for the first experimental road section

Vèžès gylio rodiklio $H_{\mathrm{v}}$ atvirkštinę priklausomybę stipriausiai sieja apsauginio šalčiui atsparaus sluoksnio storis $h_{\mathrm{S} \text { AS }}$. Remiantis gautais rezultatais ir siekiant sumažinti $H_{\mathrm{v}}$ neapibrežtį, tikslinga orientuoti tolesnius tyrimus pirmiausia ị viršutinio ir apatinio dangos sluoksnių asfaltbetonio mineralinių medžiagų kiekiu tikslinimą, viršutinio $\mathrm{AB}$ sluoksnio storio ir sutankinimo kontrolę bei didinti ịrengimo apsauginio šalčiui atsparaus sluoksnio storio kontrolę. Likusių analizuotu rodiklių neapibrèžtis neturi reikšmingos itakos rodiklio $H_{\mathrm{v}}$ modeliavimo rezultatų neapibrěžčiai. 


\subsubsection{Antrojo tyrimų ruožo rodiklių jautrumo analizè}

Regresinès analizès metu gautas determinacijos koeficientas $\left(R^{2}=1\right)$ leido jautrumo indeksais naudoti standartizuotos regresijos koeficientus (SRK). Antrajam tyrimų ruožui $Y_{\text {IRI }}$ apskaičiuoti lygties jautrumo indeksai pateikti 4.4 paveiksle.

Rodiklio $Y_{\mathrm{IRI}}$ neapibrěžčiai antrajame tyrimų ruože didžiausią ịtaką turi rodiklių $h_{\mathrm{Sk}}, h_{\mathrm{S} A S}$ (atitinkamai kelio skaldos pagrindo ir apsauginio šalčiui atsparaus sluoksnio storių) neapibrěžtis, kiek mažiau reikšminga rodiklių $V_{\mathrm{PS}}$, $M M_{\mathrm{PS}}, S K_{\mathrm{AS}}, B / M M_{\mathrm{PS}}, h_{\mathrm{AS}}$ (pagrindo sluoksnio $\mathrm{AB}$ tuštymių skaičiaus, bituminio rišiklio ir mineralinių miltelių santykio bei mineralinių miltelių kiekio, taip pat asfaltbetonio sluoksnio storio ir skaldos asfaltbetonyje kiekio) neapibrezžtis.

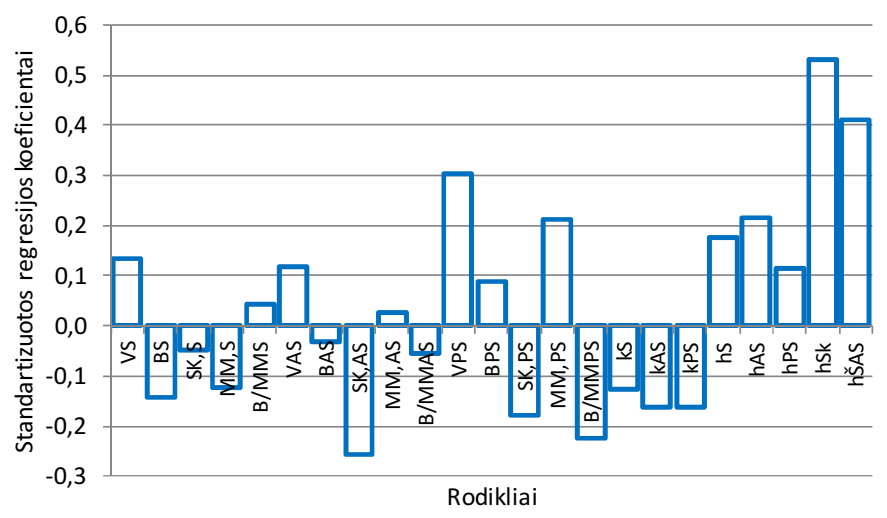

4.4 pav. Antrojo tyrimų ruožo dangos lygumo rodiklio modeliavimo tikimybinès jautrumo analizès rezultatai

Fig. 4.4. Results of probabilistic sensitivity analysis of roughness index modelling for the second experimental road section

Teigiamos jautrumo indeksų SRK rodo, kad, didejjant šiems parametrams, rodiklio $Y_{\text {IRI }}$ vertès dideja. Tarp nagrinejjamo rodiklio $Y_{I R I}$ verčių ir reikšmingu rodikliu $\left(M M_{\mathrm{PS}}, S K_{\mathrm{AS}}, B / M M_{\mathrm{PS}}\right)$ esti atvirkštinè priklausomybè - didejjant jautrumo vertèms, rodiklio $Y_{\text {IRI }}$ igyjama vertè mažeja. Remiantis gautais rezultatais ir siekiant sumažinti $Y_{\mathrm{IRI}}$ neapibrěžţ, atlikti orientuoti kontrolès tyrimus pirmiausia ị kelio pagrindo įrengimo kontrolès tyrimus, t. y. tikslesnị sluoksnių storio neapibrèžties įvertinimą. Kitụ parametrų neapibrèžtis neturi reikšmingos įtakos rodiklio $Y_{\text {IRI }}$ modeliavimo rezultatų neapibrež̌čiai.

Vèžès gylio rodiklio $H_{\mathrm{v}}$ gautų modeliavimo rezultatų pateiktų 4.5 paveiksle neapibrěžčiai didžiausią itaką turi viršutinio dangos sluoksnio asfaltbetonio 
tuštymių skaičiaus ir rodiklio $V_{\mathrm{S}}$ neapibrežtis $(\mathrm{SRK}=0,46)$, kiek mažiau reikšminga rodiklių $S K_{\mathrm{AS}}, B / M M_{\mathrm{AS}}, V_{\mathrm{PS}}, B_{\mathrm{PS}}, S K_{\mathrm{PS}}, M M_{\mathrm{PS}}, k_{\mathrm{S}}, h_{\mathrm{AS}}$ (apatinio dangos sluoksnio asfaltbetonyje esančio skaldos kiekio, bituminio rišiklio ir mineralinių miltelių santykio, pagrindo sluoksnio asfaltbetonio tuštymių ir bituminio rišiklio, skaldos bei mineralinių miltelių kiekio; $A B$ viršutinio sluoksnio sutankinimo rodiklio ir $\mathrm{AB}$ apatinio sluoksnio storio) neapibrèžtis.

Kaip matyti iš gautų rezultatų pateiktų 4.5 paveiksle, rodiklio $H_{\mathrm{v}}$ atvirkštinę priklausomybę sieja apatinio dangos sluoksnio asfaltbetonio bituminio rišiklio kiekis, pagrindo sluoksnio asfaltbetonyje esančios skaldos granuliometrija ir bituminio rišiklio kiekis (atitinkamai $B / M M_{\mathrm{AS}}, S K_{\mathrm{PS}}, B_{\mathrm{PS}}$ ).



4.5 pav. Antrojo tyrimų ruožo vèžètumo rodiklio modeliavimo tikimybinès jautrumo analizès rezultatai

Fig. 4.5. Results of probabilistic sensitivity analysis of rutting index modelling for the second experimental road section

Remiantis gautais rezultatais ir siekiant sumažinti rodiklio $H_{\mathrm{v}}$ neapibrèžti, tikslinga tolesnius tyrimus pirmiausia sutelkti i viršutinio dangos sluoksnio $\mathrm{AB}$ tuštymètumo $V_{\mathrm{S}}$ neapibrěžties tikslesni ịvertinimą, taip pat i rodiklių $S K_{\mathrm{AS}}$, $B / M M_{\mathrm{AS}}, V_{\mathrm{PS}}, B_{\mathrm{PS}}, S K_{\mathrm{PS}}, M M_{\mathrm{PS}}, k_{\mathrm{S}}, h_{\mathrm{AS}}$ tikslinimą. Likusių rodiklių neapibrěžtis neturi reikšmingos įtakos rodiklio $H_{\mathrm{v}}$ modeliavimo rezultato neapibrèžčiai.

\subsection{Magistralinių kelių tampriosios dangos racionalių konstrukcijų modeliavimas ir parinkimas}

Sudarius kelio dangos konstrukcijų (KDK) sluoksnių ir medžiagų kokybės rodiklių tiesinès priklausomybès regresines lygtis $(4.1,4.2,4.3,4.4)$ ir 
išskirsčius kintamụjų (rodiklių) įtaką kelio dangos būklès rodiklių pagal svarbą (rangus), galima sumažinti prognozuojamo kelio dangos (KD) būklès rodiklio neapibrež̌ti. Žinant prognozuojamo KD būklès rodiklio neapibrèžti, galima numatyti, kokių ribų apskaičiuota vertè kitès. Siekiant sumodeliuoti racionalią kelio konstrukciją, ịvertinant prognozuojamą KD rodiklio vertę, reikia žinoti, kokiu patikimumo laipsniu $\alpha$ būna apskaičiuotos gaunamos rodiklių vertès. Nagrinejjant sudètingas sistemas, ne visada ribinès parametrų vertès lemia rezultato ribines vertes, jas gali nulemti tam tikros parametrų verčiu kombinacijos, todèl sudarytų lygčių rezultato neapibrèžties analizè atlikta tikimybiniu būdu. Anksčiau aprašytu (2.4 poskyryje) būdu, pasitelkiant Monte Karlo metodą, atsitiktiniu būdu, iš analizuojamų rodiklių tikimybinio skirstinio, atrinktos analizuojamų rodiklių vertès ir atliktas jų verčių modeliavimas.

Teorinè ir metodine darbo dalys (apie gauto matematinio modelio (lygties) rezultatų neapibrèžti ir naudojamus metodus) aprašyta 3.1.3 poskyryje. Nagrinejjamų rodiklių ( $Y_{\mathrm{IRI}}, H_{\mathrm{V}}, V_{\mathrm{S}}, V_{\mathrm{AS}}, V_{\mathrm{PS}}, B_{\mathrm{S}}, B_{\mathrm{AS}}, B_{\mathrm{PS}}, S K_{\mathrm{S}}, S K_{\mathrm{AS}}, S K_{\mathrm{PS}}, M M_{\mathrm{S}}$, $\left.M M_{\mathrm{AS}}, M M_{\mathrm{PS}} B / M M_{\mathrm{S}}, B / M M_{\mathrm{AS}}, B / M M_{\mathrm{PS}}, k_{\mathrm{S}}, k_{\mathrm{AS}}, k_{\mathrm{PS}}, h_{\mathrm{S}}, h_{\mathrm{AS}}, h_{\mathrm{PS}}, h_{\mathrm{Sk}}, h_{\breve{\mathrm{S}}}\right)$ neapibrezžtis aprašyta tikimybinèmis pasiskirstymo funkcijomis (skirstiniais), o skirstinių histogramos ir parametrai pateikti B priede. Pasiskirstymo funkcijos buvo parinktos atsižvelgiant i gautus eksperimentinius duomenis ir įvertinus pasirinkto skirstinio tinkamumą statistikoje naudojamais „godness-of-fit testais“ (Kolmogorovo ir kt.). Monte Karlo metodu kiekvienam analizuojamam rodikliui sugeneruota 1000 rezultatų. Šių rodiklių suvestinè pateikta C priede. Parenkant skirstinị buvo atsižvelgta, ar, atsitiktiniu būdu sudarant kintamujjų verčių aibes, skaitinès vertès yra galimos (realios) fiziniu požiūriu (pavyzdžiui, dangos sluoksnio storis negali igyti neigiamas vertes).

\subsubsection{Pirmojo tyrimų ruožo modeliavimo rezultatų neapibrèžties analizè}

Atliekant tikimybinę modeliavimo analizę, buvo panaudotos sugeneruotos pirmojo tyrimų ruožo analizuotų rodiklių vertès. Sugeneruotos vertès pateiktos $\mathrm{C}$ priede. Atlikus tikimybinę modeliavimo analizę, gautos rodiklio $Y_{\text {IRI }}$ vertès, pasiskirsčiusios intervale $(0,079 ; 1,994)$. Nustatyta, kad rezultatų aritmetinis vidurkis 1,08 , o vidurkio pasikliautinas intervalas, esant 0,95 patikimumui, yra $(1,06 ; 1,10)$. Darome prielaidą, kad vertès pasiskirsčiusios pagal normaliojo skirstinio dèsnị (4.6 pav.). 


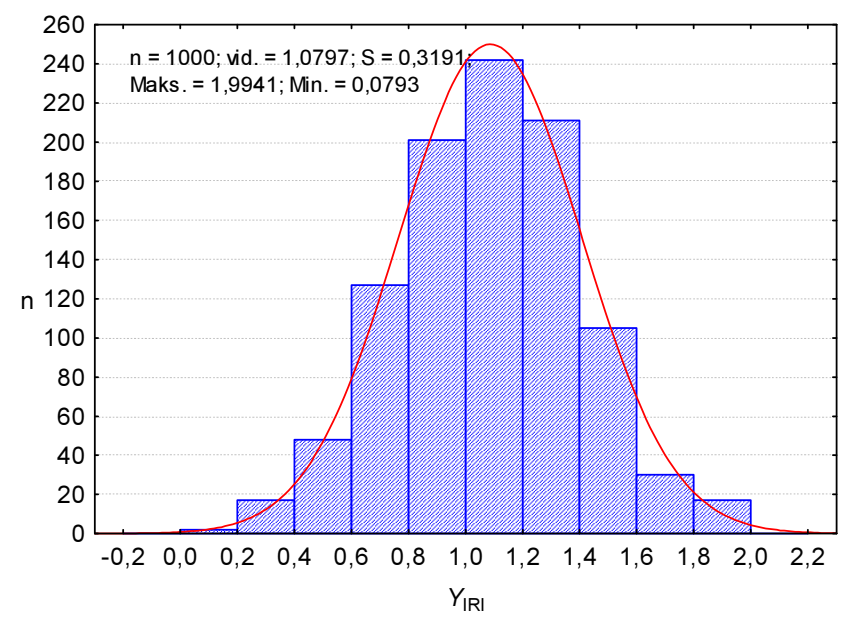

4.6 pav. Pirmojo tyrimų ruožo dangos lygumo rodiklio sumodeliuotų verčių skirstinys Fig. 4.6. Distribution of the modelled roughness index values for the first experimental road section

Rodiklių neapibrèžties tikimybinès analizès rezultatai pateikti 4.7 paveiksle.

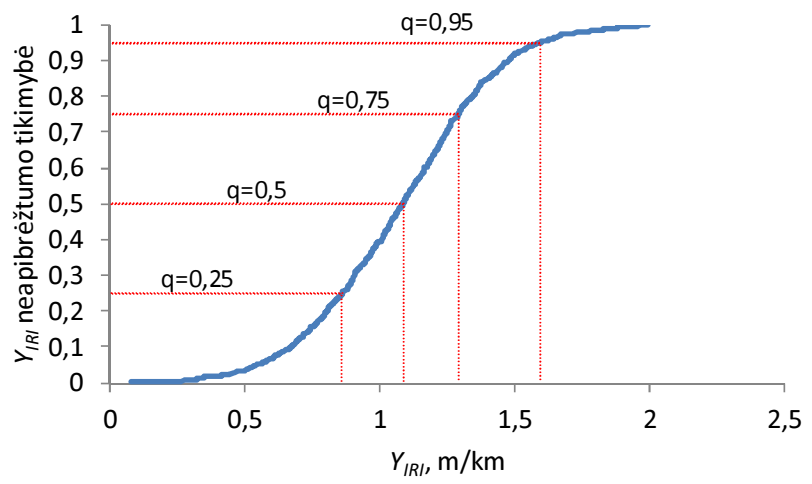

4.7 pav. Dangos lygumo rodiklio modeliavimo duomenų neapibrèžies analizès rezultatai

Fig. 4.7. Results of uncertainty analysis of index roughness index modelling results

Nustatyta, kad rodiklis $H_{\mathrm{v}}$ igyja vertes iš didesnio verčių intervalo $(0,685$; $8,962)$, didesnè verčiu sklaida $(S=1,308)$. Verčiu aritmetinis vidurkis 4,798 , o vidurkio pasikliautinasis intervalas, esant 0,95 patikimumui, yra $(4,717 ; 4,879)$. 
Vertindami tariame, kad šios vertès pasiskirsčiusios pagal normaliojo skirstinio dèsni (4.8 pav.).

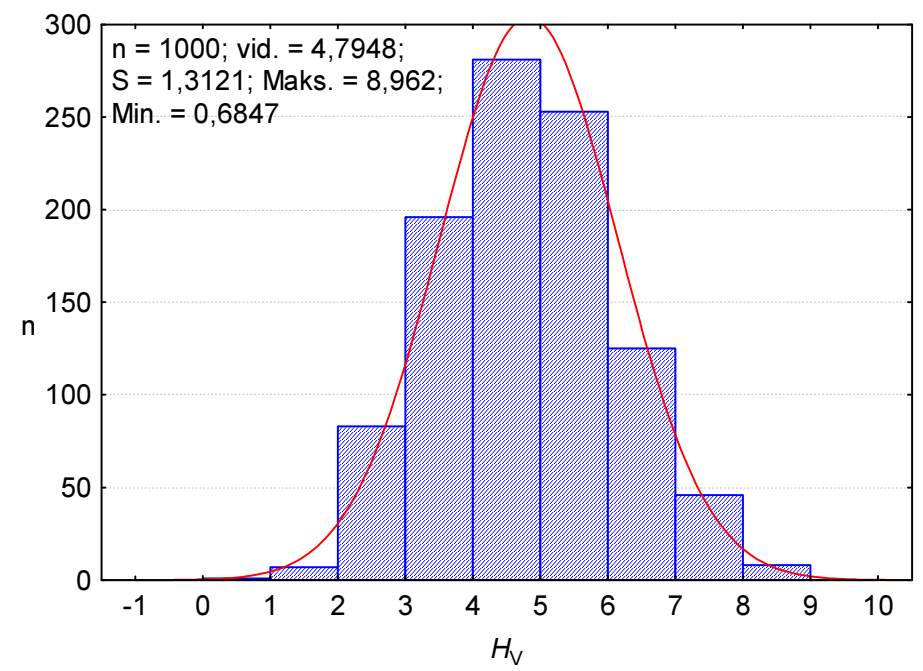

4.8 pav. Pirmojo tyrimų ruožo vėžètumorodiklio sumodeliuotų verčių skirstinys Fig. 4.8. Distribution of the modelled rutting index values for the first experimental road section

Rodiklio $H_{\mathrm{V}}$ neapibrèžties tikimybinès analizès rezultatai pateikti 4.9 paveiksle.

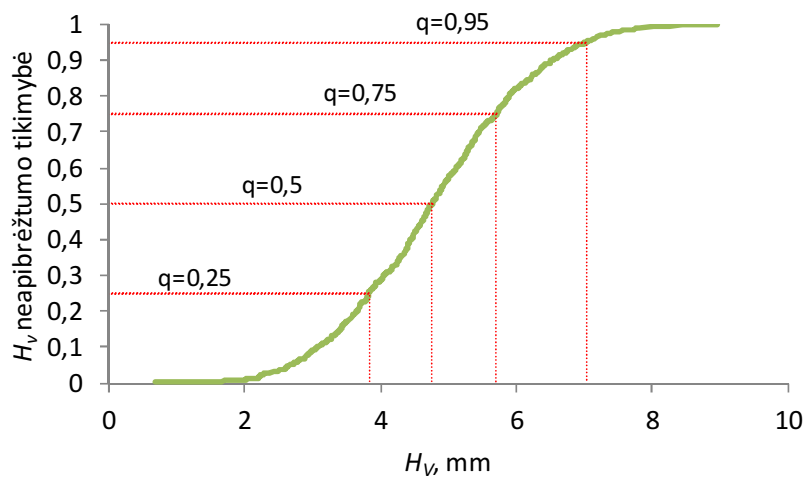

4.9 pav. Vèžètumo rodiklio modeliavimo duomenų rezultatų neapibrèžties analizės rezultatai

Fig. 4.9. Results of uncertainty analysis of index rutting index modelling results 
Nustatyti rodiklių $Y_{\text {IRI }}$ ir $H_{\mathrm{V}}$ igyjamų verčių $(\mathrm{q}=0,25,0,5,0,75,0,95)$ kvantiliai pateikti 4.2 lentelèje.

4.2 lentelè. Pirmojo tyrimų ruožo lygumo ir vèžètumorodiklių ịyjamų verčių kvantiliai Table 4.2. Quantiles of the values acquired by the roughnesss and rutting indices in the first experimental road section

\begin{tabular}{|c|c|c|c|c|}
\hline Rodiklis & $\mathrm{q}=0,25$ & $\mathrm{q}=0,5$ & $\mathrm{q}=0,75$ & $\mathrm{q}=0,95$ \\
\hline$Y_{\text {IRI }}$ & 0,864 & 1,089 & 1,293 & 1,594 \\
\hline$H_{\mathrm{v}}$ & 3,835 & 4,764 & 5,709 & 7,039 \\
\hline
\end{tabular}

\subsubsection{Antrojo tyrimų ruožo modeliavimo rezultatų neapibrèžties analizè}

Atliekant tikimybinę modeliavimo analizę, buvo naudotos sugeneruotos antrojo tyrimų ruožo rodiklių vertès. Sugeneruotos vertès pateiktos C priede. Atlikus tikimybinę modeliavimo duomenų analizę, buvo gauta, kad rodiklio $Y_{\text {IRI }}$ vertès pasiskirsčiusios intervale $(0,325 ; 2,335)$. Nustatyta, kad duomenu aritmetinis vidurkis 1,129 , o vidurkio pasikliautinasis intervalas, esant $\mathrm{P}=0,95$ patikimumui, yra $(1,111 ; 1,147)$. Vertindami tariame, kad šios vertès pasiskirsčiusios pagal normaliojo skirstinio dèsni 4.10 paveikslas.

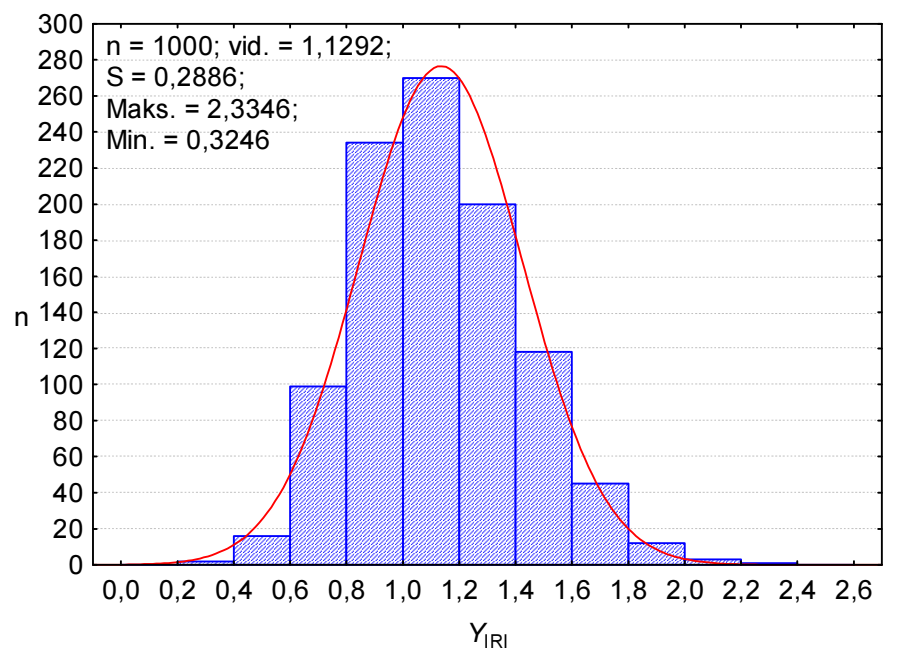

4.10 pav. Antrojo tyrimų ruožo sumodeliuotų lygumo rodiklio verčių skirstinys

Fig. 4.10. Distribution of the modelled roughness values for the second experimental road section 
Rodiklio $Y_{\text {IRI }}$ duomenų neapibrèžties tikimybinès analizès rezultatai pateikti 4.11 paveiksle.

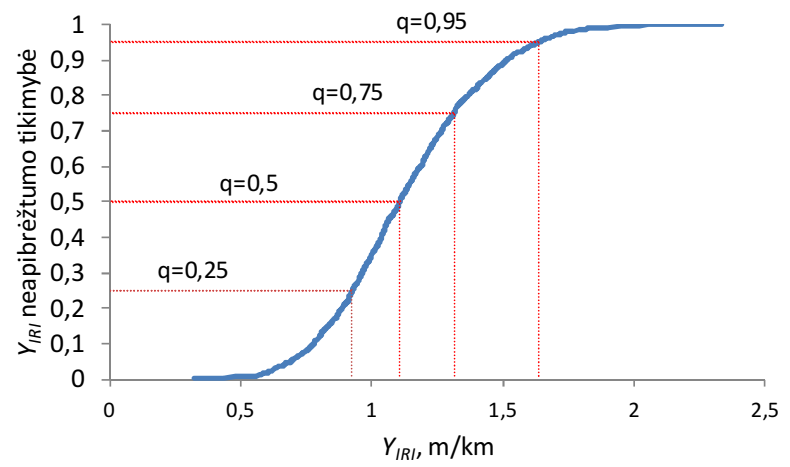

4.11 pav. Lygumo rodiklio modeliavimo duomenų neapibrèžties analizès rezultatai

Fig. 4.11. Results of uncertainty analysis of roughness index modelling results

Nustatyta, kad rodiklis $H_{\mathrm{v}}$ igyja vertes iš didesnio verčių intervalo (-1.019; $5.235)$ ir gauta didesnè šių verčių sklaida $(S=0,968)$. Verčių aritmetinis vidurkis 2,077 , vidurkio pasikliautinasis intervalas, esant 0,95 patikimumui, yra $(2,017$; 2,137). Vertindami tariame, kad reikšmès pasiskirsčiusios pagal normaluji skirstinio dèsnị 4.12 (pav).

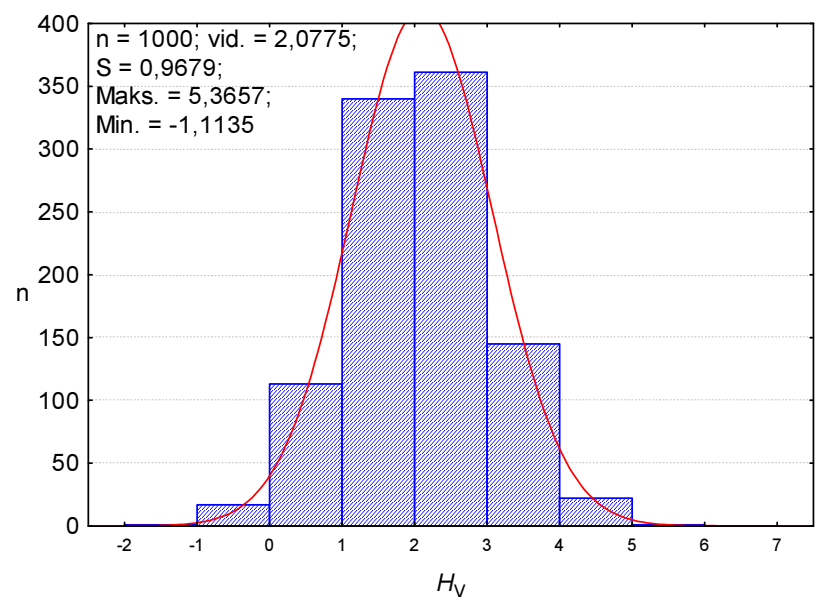

4.12 pav. Antrojo tyrimų ruožo sumodeliuotų vėžètumo rodiklio verčių skirstinys

Fig. 4.12. Distribution of the modelled rutting values for the second experimental road section 
Rodiklio $H_{\mathrm{V}}$ duomenų neapibrèžties tikimybinès analizès rezultatai pateikti 4.13 paveiksle.

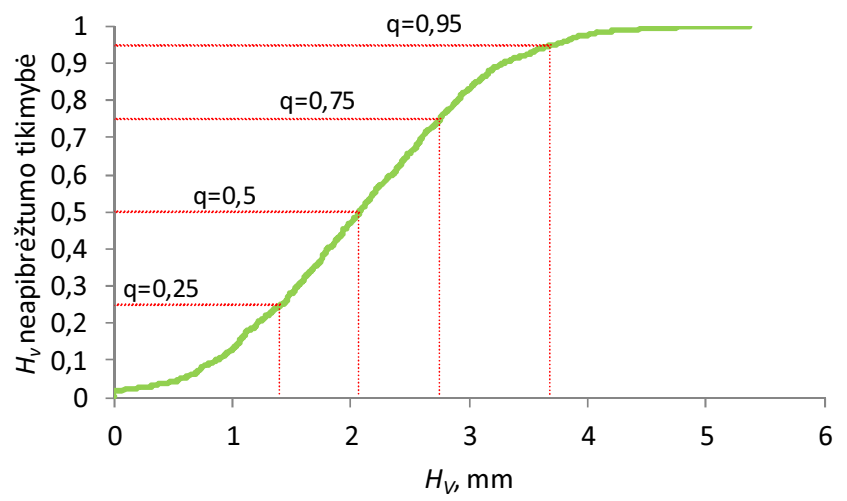

4.13 pav.Vèžètumo rodiklio modeliavimo duomenų neapibrèžties analizès rezultatai

Fig. 4.13. Results of uncertainty analysis of rutting index modelling results

Nustatyti rodiklių $Y_{\text {IRI }}$ ir $H_{\mathrm{v}}$ igyjamų verčių $(\mathrm{q}=0,25,0,5,0,75,0,95)$ kvantiliai pateikti 4.3 lentelèje.

4.3 lentelė. Antrojo tyrimų ruožo lygumo ir vėžètumo rodiklių igyjamų verčiu kvantiliai Table 4.3. Quantiles of the values acquired by theroughness and rutting indices in the second experimental road section

\begin{tabular}{|c|c|c|c|c|}
\hline Rodikliai & $\mathrm{q}=0,25$ & $\mathrm{q}=0,5$ & $\mathrm{q}=0,75$ & $\mathrm{q}=0,95$ \\
\hline$Y_{\text {IRI }}$ & 0,925 & 1,106 & 1,315 & 1,634 \\
\hline$H_{\mathrm{v}}$ & 1,400 & 2,072 & 2,755 & 3,680 \\
\hline
\end{tabular}

Apskaičiavę neapibrěžties tikimybes ir nubraižę kumuliacines pasiskirstymo funkcijas, apskaičiavome tyrimų ruožų sugeneruotų rodiklių $Y_{\text {IRI }}$ ir $H_{\mathrm{v}}$, funkcijų igyjamų verčių kvantilius. Pasinaudoję pateiktomis funkcijomis (4.7, 4.9 pav.), galime teigti, kad su tikimybe $\mathrm{P}=0,95$ pirmajame tyrimų kelio ruože rodiklis $Y_{\text {IRI }}$ igis vertę $\leq 1,59 \mathrm{~m} / \mathrm{km}$, o rodiklis $H \mathrm{v}$ vertę $\leq 7,04 \mathrm{~mm}$. Pasinaudoję funkcijomis $(4.11,4.13$ pav.) galime teigti, kad antrajame tyrimų kelio ruože su tikimybe $\mathrm{P}=0,95$ rodiklis $Y_{\text {IRI }}$ igis vertę $\leq 1,63 \mathrm{~m} / \mathrm{km}$, o rodiklis $H \mathrm{v}$ vertę $\leq 3,68$ $\mathrm{mm}$. 


\subsubsection{Magistralinių keliụ tampriosios dangos racionaliụ konstrukciju parinkimas}

Pasinaudoję gautomis kritinėmis rodiklių $Y_{\text {IRI }}$ ir $H \mathrm{v}$ vertėmis, parenkame sugeneruotų kelio konstrukcijų eilę, pateiktą D priede. Kiekvieno tyrimų ruožo sugeneruotas rodiklių $Y_{\text {IRI }}$ ir $H \mathrm{v}$ verčių eiles sugrupuojame pagal jų vertes nuo mažiausios iki didžiausios. Visas rodiklių eilutes, kurios viršija $Y_{\mathrm{IRI}}=1,59 \mathrm{~m} / \mathrm{km}$ ir $H_{\mathrm{v}}=7,04 \mathrm{~mm}$ pirmajame tyrimų ruože ir atitinkamai eilutes, kurios viršija $Y_{\text {IRI }}=1,63 \mathrm{~m} / \mathrm{km}$ ir $H_{\mathrm{v}}=3,68 \mathrm{~mm}$ antrajame tyrimu ruože, atmetėme ir toliau skaičiavome tik su likusiomis vertemis.

Racionalią kelio konstrukciją parinkome pagal du kriterijus: geriausią kelio dangos būklę nurodančio rodiklio vertę ir mažiausią apskaičiuotą KDK kainą.

KDK kainos apskaičiuotos pagal šiuo metu sąmatiniams skaičiavimams taikomus ikainius (4.4 lentelè). Kad būtų patogiau atlikti kelio dangos konstrukcijos sąmatinius skaičiavimus, medžiagų ikainius parinkome artimus analizuotų konstrukcijų sluoksnių įkainiams.

Apskaičiavę KDK kainas su sugeneruotomis (be atmestujų duomenu eilučių) KDK rodiklių vertemis (išskirsčius jas pagal mažiausią kainą), gavome keturias racionalias kelio dangos konstrukcijas iš kurių dvi gautos vienodos (4.5 lentelè).

4.4 lentelè. Kelio dangos konstrukcijos sluoksnių ikainiai, Lt (be PVM)

Table 4.4. The construction costs of road pavement structural layers, Lt, excluding VAT

\begin{tabular}{|c|c|c|c|c|c|}
\hline \multirow{2}{*}{ KDK sluoksnis } & \multicolumn{3}{|c|}{ Asfaltbetonis } & \multirow{2}{*}{$\begin{array}{c}\text { Dolomito } \\
\text { sk. 0/45 }\end{array}$} & $\begin{array}{c}\text { Smélis } \\
0 / 4\end{array}$ \\
\cline { 2 - 4 } & $\begin{array}{c}\text { SMA 11 } \\
\text { S }\end{array}$ & $\begin{array}{c}\text { AC 22 } \\
\text { AS }\end{array}$ & $\begin{array}{c}\text { AC 32 } \\
\text { PS }\end{array}$ & & \\
\hline Sluoksnio storis, cm & 4 & 8 & 14 & 30 & 40 \\
\hline $\begin{array}{c}\text { Kaina už m², Lt (be } \\
\text { PVM) }\end{array}$ & 48,8 & 65,1 & 88,8 & 53,84 & 13,2 \\
\hline
\end{tabular}

Gauti racionalių KDK sluoksnių storiai suapvalinti iki taikomų praktikoje $1 \mathrm{~cm}$ tikslumu. 4.8 lenteleje taip pat pateikti projektiniai analizuotų ruožų KDK sluoksnių storiai bei atitinkamos kelio dangos konstrukcijos irengimo (skaičiuojamosios) kainos Lt $/ \mathrm{m}^{2}$ (Lt, be PVM). Kadangi pirmajame tyrimų ruože KDK pagrindo sluoksnių storius gavome skirtingus, siekdami užtikrinti KDK stipri, racionaliai dangos konstrukcijai modeliuoti pasirinkome storesnius, gautus vertinant rodikli $Y_{\mathrm{IRI}}$, sluoksnius $\left(h_{\mathrm{Sk}}-20 \mathrm{~cm}, h_{\text {S̆AS }}-50 \mathrm{~cm}\right)$. Skaičiavimai parodè, kad, analizuojant dangos būklès vertinimo rodiklius $Y_{\text {IRI }}$ ir $H_{\mathrm{V}}$, antrajame tyrimų ruože, dangos konstrukcinių sluoksnių racionalūs storiai (esant šiems rodikliams) gauti vienodi. 
4.5 lentelè. Racionalios KDK sluoksnių storiai

Table 4.5. The rational road pavement structures

\begin{tabular}{|c|c|c|c|c|c|}
\hline Kelio ruožas & \multicolumn{2}{|c|}{ Pirmasis } & \multicolumn{2}{|c|}{ Antrasis } & \multirow{4}{*}{$\begin{array}{l}\text { Projektinès } \\
\text { vertès }\end{array}$} \\
\hline$V M P E I$, aut./para & \multicolumn{2}{|c|}{$\leq 30000$} & \multicolumn{2}{|c|}{$\leq 10000$} & \\
\hline Rodiklis & $Y_{\mathrm{IRI}}$ & $H_{\mathrm{V}}$ & $Y_{\text {IRI }}$ & $H_{\mathrm{V}}$ & \\
\hline KDK sluoksnis & \multicolumn{4}{|c|}{ KDK sluoksnio storis, $\mathrm{cm}$} & \\
\hline SMA $11 \mathrm{~S}$ & 4 & 4 & 4 & 4 & 4 \\
\hline $\mathrm{AC} 22 \mathrm{AS}$ & 7 & 7 & 7 & 7 & 8 \\
\hline AC 32 PS & 12 & 12 & 12 & 12 & 14 \\
\hline Dolomito sk. 0/45 & 20 & 16 & 22 & 22 & 30 \\
\hline Smèlis $0 / 4$ & 50 & 49 & 31 & 31 & 40 \\
\hline Kaina, Lt be PVM $/ \mathrm{m}^{2}$ & 234,68 & 227,16 & 231,84 & 231,84 & 261,93 \\
\hline
\end{tabular}

Sumodeliuotos racionalios magistralinių kelių dangos konstrukcijos pateiktos 4.14 paveiksle: (a) kai $V M P E \leq 30000$ aut./parą, (b) kai $V M P E I \leq 10000$ aut./parą).

Sumodeliuotų racionalių kelių dangos konstrukcijų įrengimo kainos sulygintos su projektinès KDK įrengimo kaina.

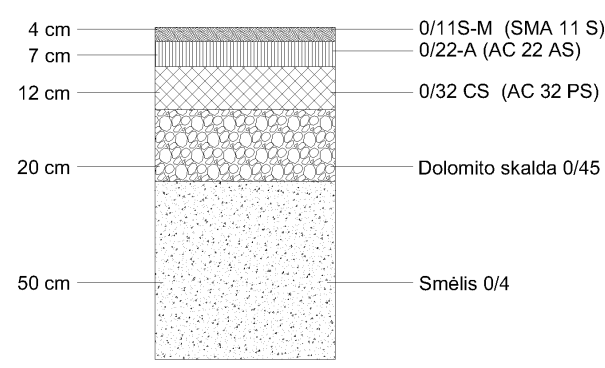

a)

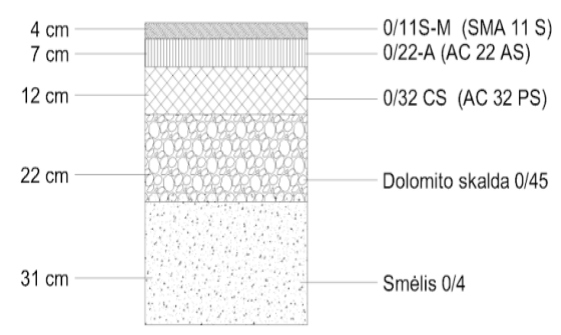

b)

4.14 pav. Sumodeliuotos racionalios kelių dangos konstrukcijos

Fig. 4.14. Rational road pavement structures for the main roads

Skaičiavimai parodè, kad sumodeliuotos racionalios kelių dangos konstrukcijos $1 \mathrm{~m}^{2}$ įrengimo kaina pirmajame tyrimų ruože 4.14 paveikslas (a), (TP eismui pagal rodikli VMPEI $\leq 30000$ aut./parą) lyginant su projektinès KDK konstrukcijos įrengimo kaina yra $10,4 \%(27,25 \mathrm{Lt}$ be PVM) mažesnè, o racionalios kelio dangos konstrukcijos antrajame tyrimų ruože (4.14 paveikslas (b)) (TP eismui pagal rodiklị VMPEI $\leq 10000$ aut./parą) mažesnè $11,5 \%$ (30,09 Lt be PVM). 


\subsection{Ketvirtojo skyriaus išvados}

1. Naudojant programinę ịrangą „STATISTICA 7“, sudaryti skirtingo transporto priemonių eismo intensyvumo magistralinių kelių asfaltbetoninès dangos eksploatacinių rodiklių prognozès matematiniai modeliai. Tyrimų rezultatai parodè, kad tarp magistralinių kelių asfaltbetoninès dangos eksploatacinių rodiklių ir tampriosios kelių dangos konstrukcijų savybių egzistuoja glaudi koreliaciné sietis. Gautuose matematiniuose modeliuose determinacijos koeficientų vertès įvairèja nuo 0,69 iki 0,85:

- determinacijos koeficientas 0,69 , vertinant kelio asfaltbetoninès dangos lygumą (kai vidutinis metinis paros eismo intensyvumas ne didesnis negu 30 000);

- determinacijos koeficientas 0,83 , vertinant kelio asfaltbetoninès dangos vèžètumą (kai vidutinis metinis paros eismo intensyvumas ne didesnis negu 30 000);

- determinacijos koeficientas 0,69, vertinant kelio asfaltbetoninès dangos lygumą (kai vidutinis metinis paros eismo intensyvumas ne didesnis negu 10 000);

- determinacijos koeficientas 0,85, vertinant kelio asfaltbetoninès dangos vèžètumą (kai vidutinis metinis paros eismo intensyvumas ne didesnis negu 10 000).

2. Atlikus dangos lygumo ir vėžètumo rodiklių prognozès tiesinių regresinių lygčių (analizuotų kelio ruožu) jautrumo analizę, galima teigti, kad:

- pirmojo kelio ruožo dangos lygumo neapibrèžtị efektyviausiai galima sumažinti, tikslinant viršutinio sluoksnio asfaltbetonio mineralinès medžiagos likučio ant $2 \mathrm{~mm}$ skersmens akelių sieto kiekio ir asfaltbetoninès dangos viršutinio sluoksnio storio neapibrèžties ịvertinimą, o dangos vèžès gylio rodiklio - tikslinant viršutinio sluoksnio asfaltbetonio mineralinès medžiagos likučio ant $2 \mathrm{~mm}$ skersmens akelių sieto kiekio ir apsauginio šalčiui atsparaus sluoksnio storio neapibrèžties įvertinimą;

- antrojo kelio ruožo dangos lygumo neapibrèžti efektyviausiai galima sumažinti tikslinant atitinkamai skaldos pagrindo ir apsauginio šalčiui atsparaus sluoksnio storius, o véžès gylio rodiklio - tikslinant asfaltbetonio viršutinio sluoksnio tuštymių kiekio rodiklio neapibrèžties ivertinimą.

3. Pasinaudojus apskaičiuotomis kumuliacinèmis neapibrèžties funkcijomis galima teigti, kad: 
- prognozuoajant keliu dangos eksploatacinius rodiklius pagal parengtus matematinius modelius, kai vidutinis metinis paros eismo intensyvumas ne didesnis negu 10000 aut./parą, dangos lygumo rodiklis ịgis vertę ne didesnę nei $1,6 \mathrm{~m} / \mathrm{km}$, o vèžètumo rodiklis - ne didesnę nei $4 \mathrm{~mm}$, esant $95 \%$ tikimybei;

- prognozuoajant keliu dangos eksploatacinius rodiklius pagal parengtus matematinius modelius, kai vidutinis metinis paros eismo intensyvumas ne didesnis negu 30000 aut./parą, dangos lygumo rodiklis ịgis vertę ne didesnę nei $1,6 \mathrm{~m} / \mathrm{km}$, o vèžètumo rodiklis - ne didesnę nei $7 \mathrm{~mm}$, esant $95 \%$ tikimybei.

4. Pasinaudojus apskaičiuotomis dangos lygum ir vėžètumo rodiklių kritinèmis vertėmis, buvo pasiūlytos racionalios kelių dangos konstrukcijos magistraliniams keliams, esant, nurodytoms transport priemonių eismo intensyvumo rodiklio vertems, ir gauti šie svarbūs rezultatai:

- esant vidutiniam metiniam paros eismo intensyvumui ne didesniam negu 10000 aut./parą, po penkerių eksploatavimo metų, kelių asfaltbetoninès dangos lygumo rodiklis bus ne didesnis nei $1,6 \mathrm{~m} / \mathrm{km}$, o jos vèžètumo rodiklis bus ne didesnis nei $4 \mathrm{~mm}$, esant $95 \%$ tikimybei;

- esant vidutiniam metiniam paros eismo intensyvumui ne didesniam negu 30000 aut./parą, po penkerių eksploatavimo metų kelių asfaltbetoninès dangos lygumo rodiklis bus ne didesnis nei $1,6 \mathrm{~m} / \mathrm{km}$, o jos vèžètumo rodiklis bus ne didesnis nei $7 \mathrm{~mm}$, esant $95 \%$ tikimybei.

5. Apskaičiavus parinktų racionalių dangos konstrukcijų įrengimo kainas, nustatyta, kad:

- parinktos racionalios kelio dangos konstrukcijos įrengimo kaina, kai vidutinis metinis paros eismo intensyvumas ne didesnis negu 10000 aut./parą, lyginant su projektinès kelio dangos konstrukcijos įrengimo kaina, yra 11,5 \% mažesnè.

- parinktos racionalios kelio dangos konstrukcijos irengimo kaina, kai vidutinis metinis paros eismo intensyvumas ne didesnis negu 30000 aut./parą, lyginant su projektinès kelio dangos konstrukcijos įrengimo kaina, yra 10,4 \% mažesnè. 


\section{Bendrosios išvados}

1. Magistralinių kelių asfaltinès dangos eksploatacinių rodiklių (dangos lygumo ir vėžètumo) verčių prognozei (penkerių metų laikotarpiui) prognozei atlikti pasiūlyti šių rodiklių prognozès matematiniai modeliai (regresijos priklausomybès). Gauti šie priklausomybių determinacijos koeficientai: 0,69, vertinant kelių dangos lygumą ir 0,83 , vertinant kelio dangos véžètumą, kai vidutinis metinis paros eismo intensyvumas neviršija 30000 aut./parą; 0,69, vertinant kelių dangos lygumą, ir 0,85 , vertinant kelio dangos véžètumą, kai vidutinis metinis paros eismo intensyvumas neviršija 10000 aut./parą.

2. Atlikus asfaltinès dangos eksploataciniu rodikliu - dangos lygumo ir vėžètumo, prognozès tiesinių regresinių lygčių jautrumo analizę, gavome, kad:

- pirmojo kelio ruožo dangos lygumo neapibrèžti efektyviausiai galima sumažinti, tikslinant: viršutinio sluoksnio asfaltbetonio mineralinès medžiagos likučio ant $2 \mathrm{~mm}$ skersmens akelių sieto kiekio ir asfaltbetoninès dangos viršutinio sluoksnio storio neapibrèžties ịverti, o kelio dangos vèžès gylio rodiklio rezultatų neapibrèžti - tikslinant viršutinio sluoksnio asfaltbetonio mineralinès medžiagos likučio ant $2 \mathrm{~mm}$ skersmens akelių sieto kiekio ir apsauginio šalčiui atsparaus sluoksnio storio neapibrež̌ties įvertị;

- antrojo kelio ruožo dangos lygumo neapibrèžti efektyviausiai galima sumažinti tikslinant skaldos pagrindo ir apsauginio šalčiui atsparaus 
sluoksnio storių neapibrèžties įvertį, o kelio dangos vèžès gylio rodiklio neapibrèžti - mažinant asfaltbetonio viršutinio sluoksnio tuštymių kiekio rodiklio neapibrèžti.

3. Pagal sudarytus kelių asfaltinès dangos eksploatacinių rodikliu prognozès matematinius modelius (po penkerių kelių dangos konstrukcijos eksploatavimo metu), esant vidutiniam metiniam paros eismo intensyvumui ne didesniam kaip 10000 aut./parą, dangos lygumo rodiklis ịgis vertę ne didesnę, kaip $1,6 \mathrm{~m} / \mathrm{km}, \mathrm{o}$ dangos vèžès gylio rodiklis - vertę ne didesnę, kaip $4 \mathrm{~mm}$, esant $95 \%$ tikimybei, esant vidutiniam metiniam paros eismo intensyvumui ne didesniam kaip 30000 aut./parą, dangos lygumo rodiklis igis vertę ne didesnę, kaip 1,6 m/km, o rodiklis $H_{\mathrm{V}}$ - vertę ne didesnę, kaip $7 \mathrm{~mm}$, esant $95 \%$ tikimybei.

4. Apskaičiavus skaičiavimus parinktos dvi racionalios kelio dangos konstrukcijos, kurios garantuoja:

- magistralinių kelių, kurių vidutinis metinis paros eismo intensyvumas neviršija 10000 aut./parą, po penkerių eksploatavimo metų, asfaltinès dangos lygumo rodiklis bus ne didesnis, kaip $1,6 \mathrm{~m} / \mathrm{km}$, o véžètumo rodiklis ne didesnis, kaip $4 \mathrm{~mm}$, esant $95 \%$ tikimybei;

- magistralinių kelių, kurių vidutinis metinis paros eismo intensyvumas neviršija 30000 aut./parą, po penkerių eksploatavimo metų, asfaltinès dangos lygumo rodiklis bus ne didesnis, kaip $1,6 \mathrm{~m} / \mathrm{km}$, o vėžètumo rodiklis ne didesnis, kaip $7 \mathrm{~mm}$, esant $95 \%$ tikimybei.

5. Apskaičiavę magistralinių kelių parinktų racionalių dangos konstrukcijų irengimo kainas, nustateme, kad:

- parinktos racionalios kelio dangos konstrukcijos, kai vidutinis metinis paros eismo intensyvumas neviršija 10000 aut./parą, irengimo kaina, lyginant su projektinès kelio dangos konstrukcijos įrengimo kaina, yra $11,5 \%$ mažesné;

- parinktos racionalios kelio dangos konstrukcijos, kai vidutinis metinis paros eismo intensyvumas neviršija 30000 aut./parą, įrengimo kaina, lyginant su projektinès kelio dangos konstrukcijos įrengimo kaina, yra $10,4 \%$ mažesnè.

6. Atlikus neapibrèžties analizę, buvo nustatytos kelio dangos lygumo ir vèžètumo ribinès vertès: kelio dangos lygumui $1,6 \mathrm{~m} / \mathrm{km}$, o vèžètumui $4 \mathrm{~mm}$, kai vidutinis metinis paros eismo intensyvumas neviršija 10000 aut./parą, ir dangos lygumui $1,6 \mathrm{~m} / \mathrm{km}$, o vėžètumui $7 \mathrm{~mm}$, kai vidutinis metinis paros eismo intensyvumas neviršija 30000 aut./parą, esant $95 \%$ tikimybei. Śą lygumo ribinę vertę galima taikyti aukštam priežiūos lygiui. Gauti rezultatai rodo, kad pasiūlytos racionalios kelio dangos konstrukcijos garantuoja gana geras kelių eismo sąlygas po penkerių kelio dangos eksploatavimo metų. 


\section{Literatūros sąrašas}

AASHTO Quide for Design of Pavement Structures. 1993. American Association of State Higway and Transportation Officials (AASHTO). 720 p.

Ahammed, M. A.; Tighe, S. L. 2008. Statistical modeling in pavement management - do the models make sense? Transportation Research Record 2084: 3-10.

Alaa H.; Abed Adel A. Al-Azzawi. 2012. Evaluation of rutting depth in flexible pavements by using finite element analysis and local empirical model, American Journal of Engineering and Applied Sciences 5 (2): 163-169 DOI 10.3844/ajeassp.2012.163.169

Al-Quadi, I. L.; Loulizi, A.; Janajrech I., et al. 2002. Pavement response to dual tires and new wide - base ties at same tire pressure, Transportation Research Record 1806: 38 47.

Amšiejus, J.; Dirgelienè, N.; Norkus, A.; Žilionienè. D. 2009. Evaluation of Soil Strength Parameters via Triaxial Testing by Height versus Diameter Ratio of Sample, The Baltic Journal of Road and Bridge Engineering 4(2): 54-60. doi:10.3846/1822427X.2009.4.54-60.

Amšiejus, J.; Kačianauskas, R.; Norkus, A.; Tumonis, L. 2010. Investigation of the Sand Porosity via Oedometric Testing, The Baltic Journal of Road and Bridge Engineering 5(3): 139-147.doi:10.3846/bjrbe.2010.20. 
Anastasopoulos, P. Ch.; Mannering, F. L. 2009. A note on modeling vehicle accident frequencies with random-parameters count models, Accident Analysis \& Prevention 41 (1): $153-159$.

Anastasopoulos, P. Ch.; Mannering, F. L.; Shankar, V. N.; Haddock, J. E. 2012. A study of factors affecting highway accident rates using the random-parameters tobit model, Accident Analysis \& Prevention, 45: p. 628-633.

Andriejauskas, T.; Vaitkus A.; Tumavičè, A. 2013. Traffic monitoring and weigh-inmotion system for lithuanian road network, The XXVIII International Baltic Road Conference, $8 \mathrm{p}$.

Asfaltbetonio dangu defektu nustatymo metodika. 1998. Kaunas: TKTI. 52 p.

Atkočiūnas, J.; Jarmolajeva, E.; Markevičiūtè, D. 2004. Optimal shakedown loading for circular plates, Structural and Multidisciplinary Optimization, 27(3): 178-188.

Automobiliu keliu remontu planavimo normatyvai. 2004. Vilnius: LAKD prie Susisiekimo ministerijos. $22 \mathrm{p}$.

Barnes, C. L.; Trottier, J.F.2010. Evaluating in-service asphalt concrete damage using surface waves, International Journal of Pavement Engineering 11(6): 449-458, DOI:10.1080/10298430903254125

Bausano, J. P.; Chatti, K.; Williams, R. C. 2004. Determining life expectancy of preventive maintenance fixes for asphalt-surfaced pavement, Transportation Research Record 1866: 1-8.

Bennert, T., Cooley Jr., L .A., Ericson, C., Zavery, Z. 2011. Coarse Aggregate Angularity and Its Relationship to Permanent Deformation of Gravel-Aggregate HotMix Asphalt in New York State, Transportation Research Record: Journal of the Transportation Research Board 2207: 25-33. doi:10.3141/2207-04.

Bertulienè, L.; Laurinavičius, A.; Lapinskienè, O. 2010. Research of Strength Measurement Methods on Subgrade of Experimental Road pavement, Proc of the $10^{\text {th }}$ International Conference "Modern Building Materials, Structures and Techniques": selected papers, vol. 1. Ed. by. Vainiūnas, P.; Zavadskas, E. K. May 19-21, 2010 Vilnius, Lithuania. Vilnius: Technika, 28-33.

Bertuliené, L.; Laurinavičius, A.; Vaitkus, A. 2010. Research and Evaluation of Methods for Determining Deformation Modulus of a Base Course of Road Pavement, The Baltic Journal of Road and Bridge Engineering 5(2): 110-115. doi:10.3846/bjrbe.2010.16.

Bhasin, A.; Castelo Branco, V. T. F.; Masad, E; Little, D. N. 2009. Quantative comparison of energy methods to characterize fatigue in asphalt materials, Journal of Materials Civil Engineering 21(2): 83-92. DOI: 10.1061/(ASCE)08991561(2009)21:2(83).

Braga, A. 2005. Dangu degradacijos modeliai ir ju taikymas Lietuvos automobiliu keliams: daktaro disertacija. Vilnius. 205 p. 
Butkevičius S. Sunkiasvorio transporto ịtaka automobiliu keliu asfaltbetonio dangos funkcionavimo trukmei: daktaro disertacija. Vilnius. $27 \mathrm{p}$.

Butkevičius, S.; Petkevičius, K.; Kamaitis, I.Z. 2007. Evaluation of flexible road pavement construction state using objective strength criteria, The Baltic Journal of Road and Bridge Engineering 2(2): 61-66.

Castro, M. Sanchez, J. A. 2007. Damage based model for prediction of asphalt concrete fatigue curves, Journal of Materials in Civil Engineering 19(8):700-702. ISSN 08991561.

Ceylan, H., Coree B., Gopalakrishnan K. 2008. Design of Rigid Pavements in Iowa Using the Mechanistic-Empirical Pavement Design Guide, The Baltic Journal of Road and Bridge Engineering 3(4): 219-225

Ceylan, H.; Schwartz, C.W.; Kim, S.; Gopalakrishuan, K. 2009. Accuracy of Predictive Models for dynamic Modulus of hot Mix asphalt, Journal of Materials in Civil Engineering 21(6): 286-293. DOI: 10.1061/(ASCE)0899-1561(2009)21:6(286)

Chang, J. R.; Su, Y.S.; Huang, T.C.; Kang, S.C.; Hsieh, S. H. 2009. Measurement of the International Roughness Index (IRI) Using an Autonomous Robot (P3-AT), in The 26th International Symposium on Automation and Robotics in Construction (ISARC 2009) 24-27 June 2009, Austin, Texas, 325-331.

Chen, J. S.; Lin, C. H.; Stein, E., et al. 2004. Development of a mechanistic-empirical model to characterize rutting in flexible pavement, Journal of Transportation Engineering 130(4): 519.

Choi, J. H.; Bahia, H. U. 2004. Life-cycle cost analysis-embedded Monte Carlo approach for modeling pay adjustament at state departmens of transportation, Transportation Research Record 1900: 86-93.

Čygas D.; Laurinavicius, A.; Vaitkus, A.; Paliukaite, M.; Motiejunas, A. 2011. A test road section of experimental pavement structures in Lithuania (ii), The 8th International Conference Environmental Engineering vol. 3: 1064-1069. ISBN 978-9955-28-829-9

Čekanavičius, V.; Murauskas, G. 2004. Statistika ir jos taikymai. II knyga. [Statistics and its Applications. II Book]. Vilnius: TEV. 259-260 p.

Čygas, D., Laurinavicius, A., Vaitkus, A., Tuminiene, F. 2007. Implementation of special requirements for asphalt concrete street pavement, Journal of Construction Science \& Engineering 3(12): 91-95.

Čygas, D.; Laurinavičius, A.; Vaitkus, A.; Perveneckas, Z.; Motiejūnas, A.2008. Research of asphalt pavement structures on lithuanian roads (I), The Baltic Journal of Road and Bridge Engineering 3(2): 77-83.

Dangu valdymo sistemos (DAVASEMA) optimizavimo metodu tobulinimas. 1997. Kaunas: TKTI. 52 p.

Dawson, A. 2008. Rut accumulation and power law models for-volume pavement under mixed traffic, Transportation Research Record 2068: 78-86. 
De Solminihac, H.; Salsilli, R.; Kohler, E., et al. 2003. Analysis of pavement serviceability for the AASHTO design method: The Chilean case, Arabian Journal for Science and Engineering 28(2B): 143-160.

Deblois, K.; Bilodeau JP.; Dore G. 2010. Use of falling weight deflectometer time history data for the analysis of seasonal variation in pavement response, Canadian Journal of Civil Engineering 37(9): 1224-1231, doi:10.1139/L10-069

Dimaitis, M. 2008. Šiuolaikins technologijos keliu dangos būklei vertinti. Lietuvos keliai 2008/1. Vilnius: Ex Arte. p. 32-35.

Ekdahl, P. 1999. Sensitivity Analysis of Two Deterioration Models for Flexible Pavements. Lund: Lund University. 102 p.

Ekdahl, P. 2000. Deterioration Models and Road Capital as Tools in Performance Contracts for Pavement Maintenance: doctoral thesis.Lund University. 172 p.

Ferne, B. 2006. Long - life pavements - a European study by ELLPAG, International Journal of Pavement engineering 7(2): 91-100.

François D.; Jullien, A. 2009. A framework of analysis for field experiments with alternative materials in road construction Waste Management, Volume 29, (1): 374-382. doi.org/10.1016/j.wasman.2008.04.005

Gui, J. (G); Phelan, P. E.; Kaloush, K. E.; Golden, J. S. 2007. Impact of pavement thermophysical properties on surface temperatures, Journal of Materials in Civil Engineering 19(8): 683-690. ISSN 0899-1561.

Guidelines of a complex methodology for nondestructive pavement measuring techniques European commission dg research, 2009

Haas, R.; Hudson, W. R.; Zaniewsky J. 1994. Modern Pavement Management. Florida: Krieger Publishing Compani. 583 p.

Haas, R.; Tighe, S. L.; Falls, L. C. 2006. Determing return on long-life pavement investments, Transportation Research Record 1974: 10-17.

Hall, J. W.; Turner, D. S. 1998. Development and adaption of early AASHO design criteria, Transportation Research Record 1612: 26-33.

Harris, D. 2013. Development of Methods and Specifications for the Use of Inertial Profilers and the International Roughness Index for Newly Constructed Pavement. Publication. Joint Transportation Research Program, Indiana Department of Transportation and Purdue University, West Lafayette, Indiana, 2013 (09). doi: $10.5703 / 1288284315211$

Highway Design and Maintenance Standards Model HDM: Model Description And User's Manual. 1981. World Bank, Washington, D.C. 227 p.

Hongbing, F.; Haddock, J. E.; White, T. D., et al. 2004. On the characterization of flexible pavement rutting using creep model-based finite element analysis, Finite Elements in Analysis and Design, 41(1): 49-73. 
Hu, S., Hu, X., Zhou, F., Walubita, L. F. 2008. SA-crack pro: New finite element analysis tool for pavement crack propagation, Transportation Research Record 1121:34-39.

Hu, S.; Hu, X.; Zhou, F.; Walubita, L.F. 2008. SA-crack pro: New finite element analysis tool for pavement crack propagation, Transportation Research Record 2068: $10-19$.

Hudson, W. R.; Flanagen, P. R. 1987. An examination of environmental versus load effects on pavement, Transportation Research Record 1121: 34-39.

Ioannides, A. M., Tallapragada, P. K. 2013. An overview and a case study of pavement performance prediction, International Journal of Pavement Engineering 14(7):629-644. Doi:10.1080/10298436.2012.715644.

IT ASFALTAS 08. 2008. Automobiliu keliu dangos konstrukcijos asfalto sluoksniu ïrengimo taisyklès. Vilnius. $62 \mathrm{p}$.

Jongvon, S.; Sandhyeok, K. 2006. Geographic information system based road way construction planning, Canadian Journal of Civil Engineering 33(5): 508-528.

Juknevičiūte, L.; Laurinavičius, A. 2008. Analysis and evaluation of depth of frozen ground affected by road climatic, The Baltic Journal of Road and Bridge Engineering 3(4): 226-232. ISSN 1822-427X

Juknevičiūtè-Žilinskienè L. (aut., disert.). Methodology for the evaluation of the effect of the climate of Lithuania on road construction and climatic regioning: summary of doctoral dissertation: technological sciences, civil engineering (02T)/Lina JuknevičiūtèŽilinskienė; Vilnius Gediminas Technical University. Vilnius: Technika, 2009. 24 p.

Karkowski, M.; Rafalski, L. 2013. The problem of overloaded vehicles in Poland, The XXVIII International Baltic Road Conference, 8 p.

Kazmierowski, T.; Ninguan, L. 2002. Modeling flexible pavement using Canadian historic data. Ninth International Conference on Asphalt Pavement. Conference Proceedings (1) CD-ROM. Codehouse, Denmark. 20 p.

Ker, H. W.; Lee, Y. H.; Lin, Ch. H. 2008. Prediction models for transverse cracking of jointed concrete pavements: Development with long-term pavement performance database, Transportation Research Record 2068: 20-31.

Khattak, J. M.; Nur, M. A.; Bhuyan, M. R. U. K.; Gaspard, K. 2013. International roughness index models for HMA overlay treatment of flexible and composite pavements, International Journal of Pavement Engineering doi: $10.1080 / 10298436.2013 .842237$

Kim, S.; Roque, R.; Birgisson, B.; Guarin, A. 2009. Porosity of the dominant aggregate size range to evaluate coarse aggregate structure of asphalt mixtures, Journal of Materials in Civil Engineering 21(1): 32-39. ISSN 0899-1561. 
Kim, Y. R.; Allen, D. H.; Little, D. N. 2005. Damage-induced modeling of asphalt mixtures through computational micromechanics and cohesive zone fracture, Journal of Materials in Civil Engineering 17(5): 477-484. ISSN 0899-1561.

Kim, Y. R.; Little, D. N.; Lytton, R. L. 2003. Fatique and healing characterization of asphalt mixtures, Journal of Materials in Civil Engineering 15(1): 75-83. ISSN 08991561.

Kim, Y. R.; Little, D. N.; Lytton, R. L. 2004. Efffect moisture damage on material properties and fatique resistance asphalt mixtures, Transportation Research Record 1891: 48-54.

Klashinsky, R.; Hanson, R.; McGibney, S. 2010. Strategic Commercial Vehicle Enforcement to Reduce GHG Emissions and Infrastructure Damage. International Road Dynamics Inc.

Komba, J. J., Anochie-Boateng J. K., Steyn W. van der M. 2013 Analytical and Laser Scanning Techniques to Determine Shape Properties of Aggregates, Transportation Research Record: Journal of the Transportation Research Board 2335: 60-71. 10.3141/2335-07.

Kopustinskas, V., Alzbutas, R., Augutis, J. Matematinių modelių parametru jautrumo ir rezultatų neapibrěžtumo statistiniai tyrimo metodai. Energetika, 2007, T. 53, Nr. 3, 10$15 \mathrm{p}$.

KPT SDK 07. 2007. Automobiliu keliu standartizuotu dangu konstrukciju projektavimo taisyklès. $63 \mathrm{p}$.

KPV PN-05. 2005. Keliụ priežiūros vadovas. I d. Automobiliu keliụ priežiūros normatyvai. Vilnius. $50 \mathrm{p}$.

KTR 1.01:2008. Keliu techninis reglamentas. Automobiliu keliai. 33 p.

Lackner, R.; Spiegl, M.; Blab, R.; Eberhardsteiner, J. 2005. Is low-temperature creep of asphalt mastic independent of filler shape and mineralogy? - arguments from multiscale analysis, Journal of Materials in Civil Engineering 17(5): 485-491. ISSN 0899-1561.

Laurinavicius, A., Vaitkus, A., Bertuliene, L., Tuminiene, F., Ziliute, L. 2009. Research of experimental road pavement structures in Lithuania, Proceedings of II International Conference Environmentally Friendly Roads-ENVIROAD 2009, editor D. Sybilski, Poland, $6 \mathrm{p}$.

Lee, H. J.; Park, H. M.; Lee, J. H. 2007. Development of a simplified design procedure for determining layer thickness in long-life pavement, Transportation Research Record 2037: 76-85.

Li, J. H.; Mahoney, J. P.; Muench, S. T.; Pierce, L. M. 2008. Bituminous surface treatment protocol for the Washington state department of transportation, Transportation Research Record 2084: 65-72.

Li, Y.; Metcalf, J. B. 2002. Crack initiation model from asphalt slab tests, Journal of Materials in Civil Engineering 14(4): 303-310. ISSN 0899-1561. 
Li, Y.; Metcalf, J. B. 2004. fatique characteristique of asphalt concrete from asphalt slab tests, Journal of Materials in Civil Engineering 16(4): 306-314.

Lietuvos automobiliu keliu direkcija. 2013. 3p.

Loizos, A. 2006. Assessment and upgrading of in-service heavy duty pavements to long life, International Journal of Pavement Engineering 7(2): 133-144.

Loria, L.; Sebaaly, P. E.; Hajj, E. Y. 2008. Long-term performance of reflective cracking mitigation technique in Nevada, Transportation Research Record 2044: 86-95.

LST EN 12697-1:2012. Bituminiai mišiniai. Karštojo asfalto mišinio bandymo metodai. 1 dalis. Tirpiojo rišiklio kiekis

LST EN 12697-27:2002. Bituminiai mišiniai. Karštojo asfalto mišinio bandymo metodai. 27 dalis. Éminiu èmimas

LST EN 12697-29. Bituminiai mišiniai. Karštojo asfalto mišinio bandymo metodai. 29 dalis. Bandiniu matmenu nustatymas

LST EN 12697-30. Bituminiai mišiniai. Karštojo asfalto mišinio bandymo metodai. 30 dalis. Bandinio paruošimas smūginiu tankintuvu

LST EN 12697-6. Bituminiai mišiniai. Karštojo asfalto mišinio bandymo metodai. 6 dalis. Bituminiu bandiniu tariamojo tankio nustatymas

LST EN 12697-8. Bituminiai mišiniai. Karštojo asfalto mišinio bandymo metodai. 8 dalis. Bituminiu bandiniu tuštymètumo rodikliu nustatymas

Lundstrom, R.; Di Benedetto, H.; Isacsson, U. 2004. Influence of asphalt mixture stiffness on fatique failure, Journal of Materials in Civil Engineering 16(6): 516-525. ISSN 0899-1561

Ma T.; Huang X.; Zhao Y.; Yuan H.; Ma X. 2012. Degradation Behavior and Mechanism of HMA Aggregate, Journal of Testing and Evaluation 40(5): 697-707. doi: 10.1520/JTE20120057

Macekainis, V. 2006. Magistralinių kelių asfaltbetonio dangų būklè, Lietuvos keliai 2: 64-67 p.

Markauskas, D.; Kačianauskas, R.; Džiugys, A.; Navakas, R. 2010. Investigation of adequacy of multi-sphere approximation of elliptical particles for DEM simulations, Granular Matter 12: 107-123. doi:10.1007/s10035-009-0158-y

Marzouk, M.; Awad, E.; Moheeb El-Said. 2012. Kompleksinė priemonè automobilių keliu dangu atnaujinimo programoms optimizuoti, The Baltic Journal of Road and Bridge Engineering (7)4: 297-304.

Merilla, D.; Dommelenb, V.A.; Gasparc, L. 2006. A review of practical experience throughout Europe on deterioration in fully-flexible and semi-rigid long-life pavement, International Journal of Pavement Engineering 7(2): 101-109.

Moaveni, M., Wang, S., Hart, J. M., Tutumluer, E., Ahuja, N. 2013. Evaluation of Aggregate Size and Shape by Means of Segmentation Techniques and Aggregate Image 
Processing Algorithms, Transportation Research Record: Journal of the Transportation Research Board 2335:50-59. 10.3141/2335-06.

Motiejūnas, A.; Paliukaitè, M.; Vaitkus, A.; Čygas, D.; Laurinavičius, A. 2010. Research of Dependence of Asphalt Pavement Stiffness upon the Temperature of Pavement Layers, The Baltic Journal of Road and Bridge Engineering 5(1): 50-54. doi:10.3846/bjrbe.2010.07.

Mučinis D., Sivilevičius H., Oginskas R. 2009. Factors Determining the Inhomogeneity of Reclaimed Asphalt Pavement and Estimation of its Components Content Variation Parameters, The Baltic Journal Of Road And Bridge Engineering, 4(2): 69-79.

Múčka, P. 2012. Relationship between International Roughness Index and Straightedge Index, Journal of Transportation Engineering 138(9): 1099-1112. doi: 10.1061/(ASCE)TE.1943-5436.0000417

Múčka, P. 2013. Correlation among Road Unevenness Indicators and Vehicle Vibration Response, Journal of Transportation Engineering 139(8): 771-786. doi:10.1061/(ASCE)TE.1943-5436.0000417

Múčka, P. 2013. Influence of road profile obstacles on road unevenness indicators, Road Materials and Pavement Design: 1-14. doi: 10.1061/(ASCE)TE.1943-5436.0000417

Noureldin, A. S. 1997. Quantifying the effect of pavement performance characteristics, Transportation Research Record 1575: 75-84.

Pellinen, T. K.; Christensen, D. W.; Rove, G. M.; Sharok, M. 2004. Fatique transfer functions - how do they compare? Transportation Research Record 1896: 77-87.

Perera, R. W.; Kohn, S. D. 2012. Issues in Pavement Smoothness: A Summary Report. NCHRP, Transportation Research Board, 20-51 p.

Paterson, W. D. O. 1987. Road Deterioration and Maintenance Effects: Models for Planning and Management. A World Bank Publication. The Johns Hopkins University Press. Baltimore, $453 \mathrm{p}$.

Paterson, W. D. O.; Bennet, Ch. 2001. Calibration and Validation of HDM-4. 44 p.

Petkevičius E., (aut., disert.) Automobilių kelių asfaltbetonio dangos eksploatacinių rodiklių leistinujų verčių pagrindimas, Evaldas Petkevičius: technologijos mokslai, statybos inžinerija (02T); Vilniaus Gedimino technikos universitetas. Vilnius: Technika 2010.

Petkevičius K. Automobilių kelių asfaltbetonio dangos ir jos konstrukcijos tarpremontiniai laikotarpiai ir metodika jiems nustatyti. Miesto plètra ir keliai. Mokslo žurnalo „Statyba“ priedas. 2000, p. 94. ISBN 9986-05-143-1.

Petkevičius, K.; Sivilevičius, H. 2000. Automobilių keliu asfaltbetonio dangos ir jos konstrukcijos reikiamos savybės ir racionali funkcionavimo trukmè, Transportas 15(4): 184-195. ISSN 1392-1533.

Petkevičius K. Podagèlis I. 2000. Didžiausią atsparumą nuovargiui laiduojanti optimali asfaltbetonio sudètis, Miestu plètra ir keliai 49-54 p. 
Petkevičius, E.; Laurinavičius, A.; Petkevičius, R.; Babickas, R. 2009. Effect of components content on properties of hot mix asphalt mixture and concrete, The Baltic Journal of Road and Bridge Engineering 4(4): 161-167. DOI: 10.3846/1822427X.2009.4.161-167.

Petkevičius, K. (aut., disert.). Automobilių kelių asfaltbetonio dangos būkles tyrimai ir jų rezultatų taikymas : habilitacijos procedūrai teikiamų mokslo darbų apžvalga Kazys Petkevičius: technologijos mokslai, statybos inžinerija (02T);Vilniaus Gedimino technikos universitetas. Vilnius: Technika, 2008: 39 p. ISBN 9789955283416.

Petkevičius, K.; Sivilevičius, H. 2008. Necessary measures for ensuring the quality of hot mix asphalt in Lithuania, The Baltic Journal of Road and Bridge Engineering 3(1): $29-37$.

Pradhan, N. P.; Hennig, T.; Wilson, D. J. 2001. Development of pavement deterioration modeling in New Zealand. A Rewiew of Achievements. HTC Infrastructure Management Ltd. $56 \mathrm{p}$.

Puodžiukas, V. Bituminous pavement evoluation and strengthening neeis assessment in Lithuania. Summary of doctoral dissertation. Vilnius: Technika, 2000. 42 p.

Radziszewski, P. 2007. Modified Asphalt Mixtures resistance to Permanent Deformations, Journal of Civil Engineering and Management International Research and Achievements 13(4): 307-315. DOI:10.1080/13923730.2007.9636451

Romero, J. A.; Lozano, A., et al. 2006. Effect of truck suspension and tire properties on pavement damage spatial distribution, Transportation Research Record 1949: 148-154.

Richter, C. A.; Schwartz, C. W. 2003. Modeling stress - and moisture-induced variation in pavement layer moduli, Transportation Research Record 1860: 33-40

RSN 256-94. Statybinè klimatologija. 1995. Vilnius: Aplinkos ministerija. 136 p.

Sandra, A. K.; Sarkar, A. K., 2012. Development of a model for estimating International Roughness Index from pavement distresses, International Journal of Pavement Engineering 14 (8): 715-724. doi: 10.1080/10298436.2012.703322.

Salama, H. K.; Chatti, K., et al. 2006. Effect of heavy multiple axle trucks on flexible pavement damage using in-service pavement perfomance data, Journal of Transportation Engineering - ASCE 132(10): 763-770.

Schmuck, A.; Hehenberger, F. 1993. Mängelursachen, Erhalfungsmaßnahmen und Auswirkungen auf das Zustandsniveau-Endviclung einer Systematic für das Management der Straßenerhaltung Forch, Strassenbau und Strassenverkehrstechn 652: 118.

Seo, Y.; El-Haggan, O.; King, M.; Lee, S. J.; Kim, Y. R. 2007. Air Void models for the dynamic modulus, fatique cracking, and rutting of asphalt concrete, Journal of Materials in Civil Engineering 19(10): 874-883. ISSN 0899-1561. 
Šiaudinis G., Čygas D. 2007. Determination of Seasonal Effects on the Structural Strength of Asphalt Pavements, The Baltic Journal of Road and Bridge Engineering 2(2): 67-72.

Sivilevičius, H.; Petkevičius, K. 2002. Regularities of defect development in the asphalt concrete road pavement. Journal of Civil Engineering and Management 8(3): 206-213.

Sivilevičius H., Vansauskas V. 2013. Research and evaluation of ruts in the asphalt pavement on Lithuanian highways, Journal of Civil Engineering and Management 19(5): 609-621. DOI:10.3846/13923730.2013.817481

Sivilevičius H.; Zavadskas, E. K.; Turskis Z. 2008. Quality Attributes And Complex Assessment Methodology of the Asphalt Mixing Plant, The Baltic Journal of Road and Bridge Engineering 3(3): 161-166. DOI: 10.3846/1822-427X.

Sivilevičius, H. 2011. Modelling the Interaction of Transport System Elements, Transport 26(1): 20-34. doi:10.3846/16484142.2011.560366

Sivilevičius, H. The quality improvement system of asphalt concrete mixture production technological process: summary of the research report presented for habilitation: technological sciences, civil engineering (02T); Vilnius Gediminas Technical University. Vilnius : Technika, 2003. $36 \mathrm{p}$

Sivilevicius, H.; Vislavicius, K. 2008. Stochastic Simulation of the Influence of Variation of Mineral Material Grading and Dose Weight on Homogeneity of Hot Mix Asphalt, Construction and Building Materials 22(9): 2007-2014. http://dx.doi.org/10.1016/j.conbuildmat.2007.07.001

Sivilevičius, H.; Šukevičius, Š. 2009. Manufacturing technologies and dynamics of hotmix asphalt mixture production. Journal of Civil Engineering and Management 15(2): 169-179. ISSN 1392-3730 print./ISSN 1822-3605 online.

Skrinskas, S.; Gasiūnienè, V. E.; Laurinavičius, A.; Podagèlis, I. 2010. Lithuanian mineral resources, their reserves and possibilities for their usage in road building, The Baltic Journal of Road and Bridge Engineering 5(4): 218-228. ISSN 1822-427X

Sokolov, J.; Sivilevičius, H. 2011. Sunkiujų automobilių sąveikos su kelio danga ir jų itakos konstrukcijos sluoksniams analizè, Mokslas - Lietuvos ateitis 3(2): 103-109. doi: $10.3846 /$ mla.2011.040

Sunkiu transporto priemoniu itakos asfaltbetonio dangos konstrukcijoms, ìvertinant automobiliu srautus valstybinès reikšmès keliuose, tyrimai ir vertinimas. 2009. Vilnius: VGTU. 211 p.

ST 9306149.02: 2002. Pažaidu taisymas gatviu asfaltbetonio dangoje. Statybos taisyklès. Vilnius: Vilniaus miesto savivaldybès Energetikos ir ūkio departamento Miesto ūkio skyrius. $10 \mathrm{p}$. 
Tarefder, R., Rodriguez-Ruiz, J. 2013. Local Calibration of MEPDG for Flexible Pavements in New Mexico. Journal of Transportation Engineering 139(10): 981-991. doi.org/10.1061/(ASCE)TE.1943-5436.0000576.

Thodesen, C. C.; Lerfald, B. O.; Hoff, I. 2012. Review of asphalt pavement evaluation methods and current applications in Norway, The Baltic Journal of Road and Bridge Engineering. 7(4): 246-252. DOI: 10.3846/bjrbe.2012.33

Tarelder, R. A.; White, L.; Zaman, M. 2005. Development and application of a rut prediction model for flexible pavement, Transportation Research Record 1936: 201-209.

Tighe, S.; Huen, K.; Haas, R. 2007. Environmental and traffic deterioration with mechanistic - empirical pavement design model: Canadian example, Transportation Research Record 1989(2): 336-343.

Timm, D.H.; Newcomb, D.E.2006. Perpetual pavement design for flexible pavements in the US, International Journal of Pavement Engineering 7(2): 111-119.

TRA ASFALTAS 08.Automobiliu keliu asfalto mišiniu techniniu reikalavimu aprašas. Vilnius. 2008

TRA MIN 07. Automobiliu keliu mineraliniu medžiagu. techniniu reikalavimu aprašas. Vilnius. 2007

Vaitkus, A.; Čygas, D.; Laurinavičius, A.; Perveneckas, Z. 2009. Analysis and evaluation of possibilities for the use of warm mix asphalt in Lithuania, The Baltic Journal of Road and Bridge Engineering 4(2): 80-86. DOI: 10.3846/1822427X.2009.4.80-86

Vaitkus, A.; Laurinavičius, A.; Oginskas, R.; Motiejūnas, A.; Paliukaitè, M.; Barvidienè, O.2012. The road of experimental pavement structures: experience of five years operation, The Baltic Journal of Road and Bridge Engineering 7(3): 220-227. ISSN 1822-427X

Vaitkus, A.; Puodžiukas, V.; Motiejūnas, A.; Vitkienè, J.; Vorobjovas, V.; Paliukaite, M. 2010. Long term research of experimental asphalt pavement structures. Transport Research Arena Europe, Brussels, Belgium, 7-10 June : proceedings [DVD] Brussels : The European Road Transport Research Advisory Council 1-8 p.

Vaitkus, A.; Vorobjovas, V.; Žiliūtė, L.; Kleizienè, R.; Ratkevičius, T. 2012. Optimal selection of soils and aggregates mixtures for a frost blanket course of road pavement structure, The Baltic Journal of Road and Bridge Engineering 7(2): 154-159. ISSN 1822-427X

Vislavicius, K.; Sivilevicius, H. 2013. Effect of Reclaimed Asphalt Pavement Gradation Variation on the Homogeneity of Recycled Hot-Mix Asphalt, Archives of Civil and Mechanical Engineering 13(3): 345-253. http://dx.doi.org/10.1016/j.acme.2013.03.003. 
Wang, H. 2006. Road Profiler Performance Evaluation and Accuracy Criteria Analysis.Master thesis, Civil and Environmental Engineering, Virginia Polytechnic Institute and State University.

Wu, Z., Yang, X., Zhang, Z. 2013. Evaluation of MEPDG flexible pavement design using pavement management system data: Louisiana experience, International Journal of Pavement Engineering 14(7): 674-685. Doi:10.1080/10298436.2012.715644.

Yavuzturk, C.; Ksaibati, K.; Chiasson, A. D. 2005 Assessment of temperature fluctuation in asphalt pavements due to thermal environmental condition using a twodimensional, transient finite-difference approach, Journal of Materials in Civil Engineering 17(4): 465-475. ISSN 0899-1561.

Yu, H. S. 2005. Road materials and pavement desing - Foreword, Road Materials and Pavement 6(1): 7-14.

Zhang, Z. M.; Leidy, J. P.; Kawa, I., et al. 2000. Impact of changing traffic characteristics and environmental condition on flexible pavement, Transportation Research Record 1730: 125-131.

Žilionienè, D.; De L., M.; Dellacqua, G.2013. Evaluation of climatic factors based on the mechanistic -empiric al pavement de sign guide, The Baltic Journal of Road and Bridge Engineering 8(3): 158-165. ISSN 1822-427X

Žiliūtè, L.; Laurinavičius, A. 2013. Traffic load impact on the initiation and development of plastic deformations in road asphalt pavements, The Baltic Journal of Road and Bridge Engineering 8(3): 220-226. ISSN 1822-427X

Апестин, В. К. 2007. Требования к предельному состоянию нежестких дорожных одежд, Наука и техника в дорожной отрасли 41(2): 16-17

Бахрах, Г. С. 2008. Проектирование нежестких дорожных одежд по критерию усталостного растрескивания, Наука и техника в дорожной отрасли 45(2): 32-34.

Золотарев, В. А. 2004. Влияние свойств битумополимерных вяжущих на здвигоустойчивость асфальтобетонов, Наука и техника в дорожной отрасли 29(2): 27-30.

Иваньски, М. 2003. Влияние вида минерального материала на свойства асфальтобетона, Наука и техника в дорожной отрасли 25(2): 35-37.

Рыбьев, И. А. 2008. Строительное материаловедение. Москва: Высшая школа. $701 \mathrm{c}$.

Коганзон, М. С.; Лугов, С. В. 2004. Расчет и конструирование дорожных одежд по критерию допустимой остаточной деформации, Наука и техника в дорожной отрасли 30(3): 17-19.

Радовский, Б. С.; Сердюк, А. В. 1997. Прогнозирование закономерности изменения состояния дорожной одежды, Автомобильные дороги 7: 19-21. 
Яромко, В. Н. 2008. О совершенствовании проектирования дорожных одежд нежесткого типа, Наука и техника в дорожной отрасли 45(2): 28-31. 



\section{Autoriaus mokslinių publikacijų disertacijos tema sąrašas}

\section{Straipsniai recenzuojamuose mokslo žurnaluose}

Bulevičius, M., Petkevičius, K., Žilionienè, D., Čirba S. 2011. Statistical analysis of thermal and weathering, physical-mechanical properties of aggregates used for producing asphalt mixtures test results, The Baltic Journal of Road and Bridge Engineering 6(2): 115-123 doi: 10.3846/bjrbe.2011.16 (Thomson Reuters Web of knowledge).

Bulevičius, M., Petkevičius, K., Čirba S. 2013. The influence of geometric parameters on strength properties of the aggregates used to produce asphalt mixtures, Journal of Civil Engineering and Management 19(6): 894-902 doi:10.3846/13923730.2013.858645 Thomson Reuters Web of knowledge).

\section{Straipsniai kituose leidiniuose}

Bulevičius, M., Petkevičius, K., Žilionienè, D., Čirba S., Oginskas, R., Bertuliene, L. 2011.The influence of geometrical parameters on the strength of crushed stone used for the manufacture of asphalt mixtures. 8th international conference „Environmental Engineering”, Selected Papers (19-20 May 2011, Vilnius, Lithuania) 3: 1160-1161. ISBN 978-9955-28-826-8 (Thomson ISI Proceedings).

Bertulienè, L., Oginskas, R., Bulevičius, M. 2011. Research of rut depth in asphalt pavements reinforced with geosynthetic materials. 8th international conference „, Environmental Engineering”: Selected Papers (19-20 May 2011, Vilnius, Lithuania) 2: 738-743. ISBN 978-9955-28-826-8 (Thomson ISI Proceedings). 
Bulevičius, M., Petkevičius, K., Žilionienè, D., Drozdova, K. 2010. Testing of physical-mechanical properties of coarse aggregate, used for producing asphalt mixtures, and analysis of test results. 10th international conference „Modern building, materials, structures and techniques": Selected Papers (16-21 May 2004, Vilnius, Lithuania): 186-192. ISBN 978-9955-28-594-6 (Thomson ISI Proceedings).

Булявичюс М.; Петкявичюс К.; Жиленене Д. Исследование физикомеханических свойств крупных заполнителей, применяемых для производства асфальтовых смесей в Литве, Материалы Международной научно-практической конференции, посвященной 90-летию Белорусского начионального технического университета, "Перспективные направления проектирования, строительства и эксплуатации дорог, мостов $u$ подземных сооружений" чясть 1. 21-22 октября 2010 г. Минск, Беларусь, Минск: БНТУ, 18-24. 


\section{Priedai $^{1}$}
A priedas. Kelio dangos konstrukcinių sluoksnių savybių sieties analizè
B priedas. Kelio dangos konstrukcinių sluoksnių rodiklių skirstiniai
C priedas. Sugeneruoti kelio dangos konstrukcinių sluoksnių rodikliai
D priedas. Sugeneruotos kelio dangos konstrukcijos 



\section{Matas BULEVIČIUS}

KELIŲ TAMPRIOSIOS DANGOS KONSTRUKCIJỤ SAVYBIŲ ITAKA JŲ VIRŠUTINIO SLUOKSNIO EKSPLOATACINIAMS RODIKLIAMS

Daktaro disertacija

Technologijos mokslai, statybos inžinerija (02T)

\section{Matas BULEVIČIUS}

INFLUENCE OF THE PROPERTIES OF FLEXIBLE ROAD PAVEMENT STRUCTURE ON THE SERVICE INDICES OF WEARING COURSES

Doctoral Dissertation

Technological Sciences, Civil Engineering (02T)

201312 13. 11,75 sp. I. Tiražas 20 egz.

Vilniaus Gedimino technikos universiteto

leidykla „Technika“,

Saulètekio al. 11, 10223 Vilnius,

http://leidykla.vgtu.It

Spausdino UAB "Ciklonas"

J. Jasinskio g. 15, 01111 Vilnius 